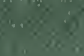

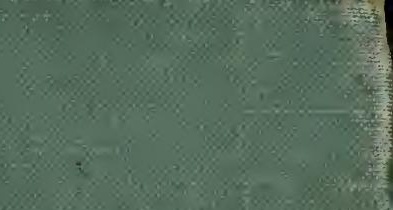

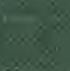

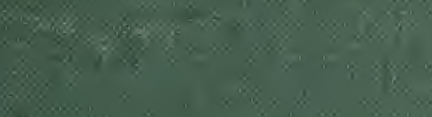

-

8

3.

ix:

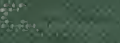

$4=$

(y) -3

2.8

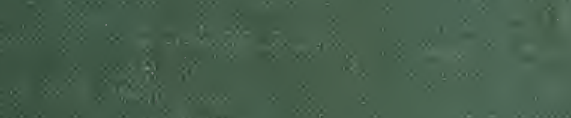

(4) 8

$x^{2} x^{x} x^{2}$.

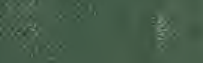

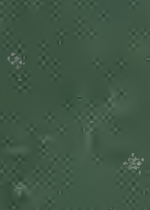

3

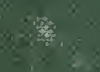
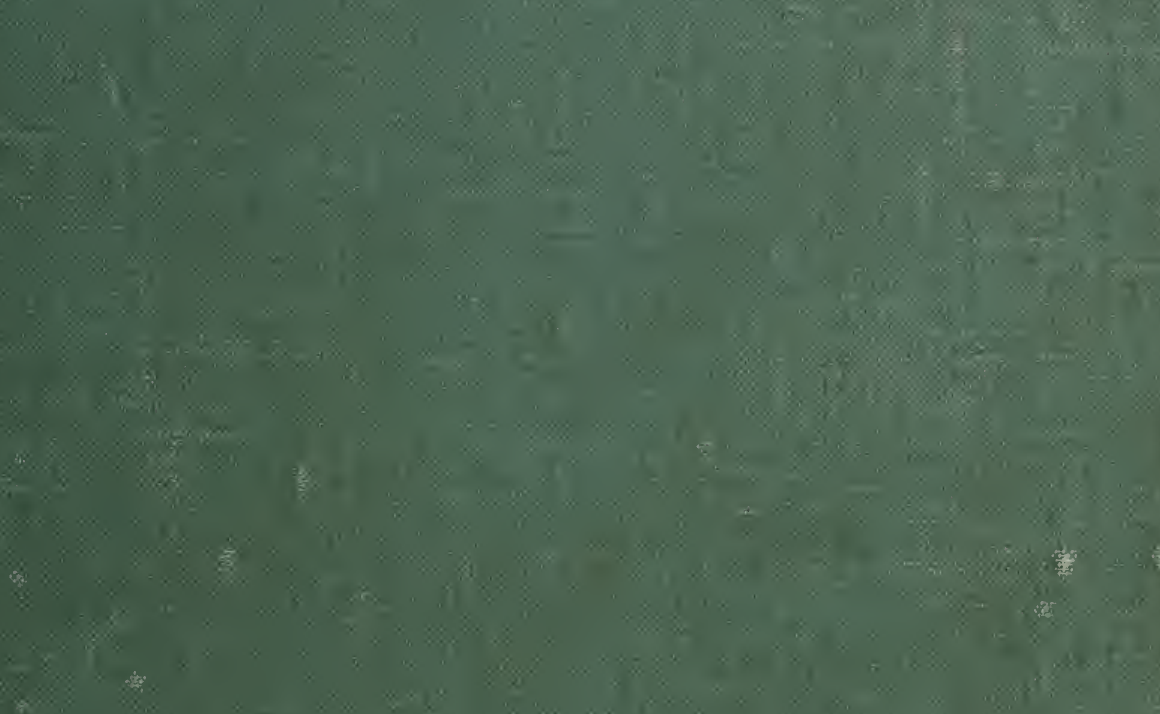

in 8

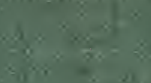

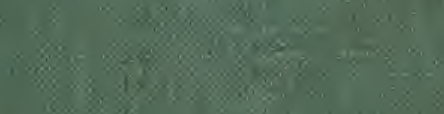
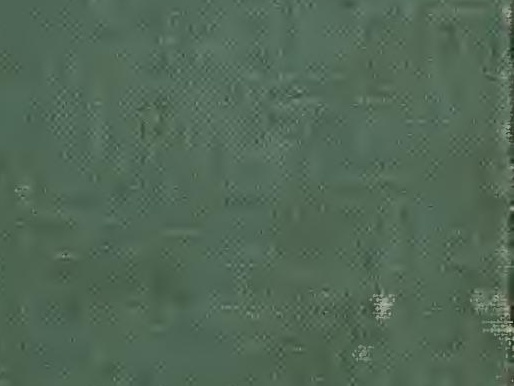

×
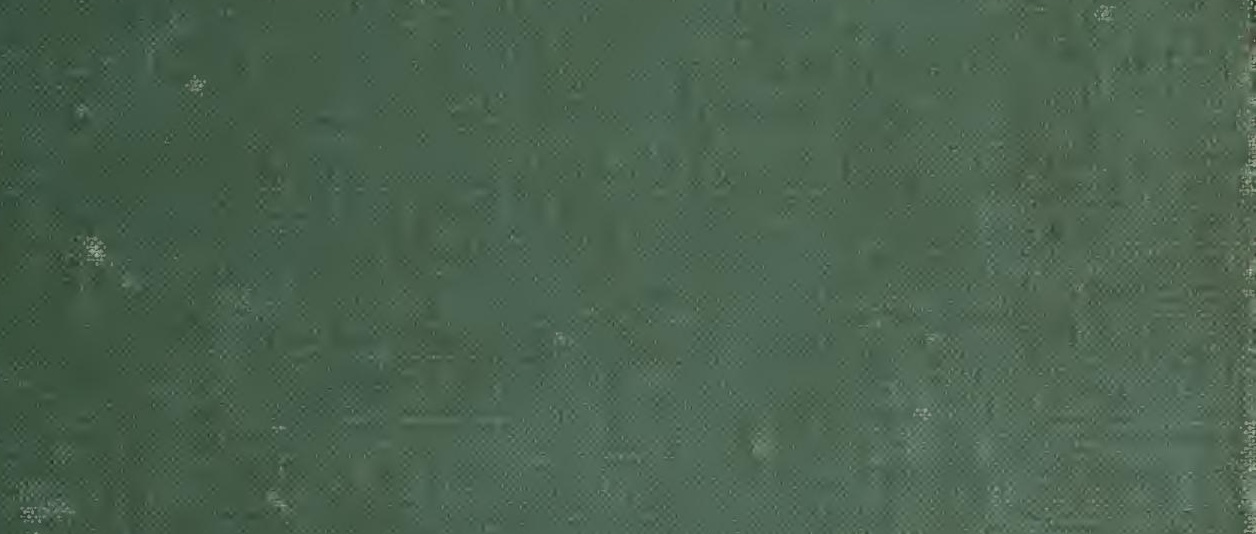


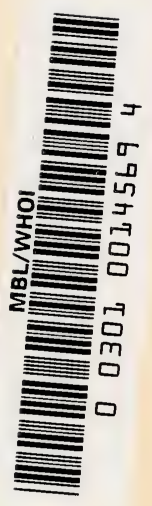



WISCONSIN GEOLOGICAL AND NATURAL HISTORY SURVEY w. O. HOTCHKISS, Director

\section{Phytoplankton of the Inland Lakes of Wisconsin}

\section{Part I}

Myxophyceae, Phaeophyceae, Heterokonteae, and Chlorophyceae exclusive of the Desmidiaceae.

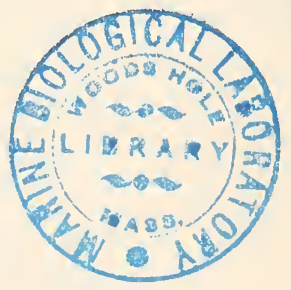




\section{Wisconsin Geological and Natural History Survey}

\section{BOARD OF COMMISSIONERS.}

EMANUEL L. PHILIPP,

Governor of the State.

EDWARD A. BIRGE, President.

President of the University of Wisconsin.

President of the Wisconsin Academy of Sciences, Arts, and Letters.

CHARLES P. CARY, Vice-President.

State Superintendent of Public Instruction.

\section{STAFF OF THE SURVEY, 1919.}

ADMINISTRATION:

William O. Hotchkiss, State Geologist, Director and Superintendent.

In immediate charge of Geology Division.

Ernest F. Bean, Assistant State Geologist.

Lillian M. Veerhusen, Chief Clerk.

Frances Walker, Clerk and Stenographer.

Angeline Doll, Clerk.

\section{(:EOLOGY DIVISION:}

William O. Hotchkiss, In charge.

Ernest F. Bean, Geologist, Mineral Land Classification.

T. C. Chamberlin, Consulting Geologist, Pleistocene Geology.

E. O. Ulrich, Consulting Geologist, Stratigraphy, by cooperation of the U. S. G. S.

H. R. Aldrich, Geologist.

Clare Gillis, Geologist.

R. H. Whitbeck, Geographer.

T. J. Dunnewald, Field Assistant and Analyst.

F. T. Thwaites, Geologist, Well Records, Educational Rock Collection.

NATURAL HISTORY DIVISION:

Edward A. Birge, In charge.

Chancey Juday, Lake Survey.

\section{DIVISION OF SOILS:}

A. R. Whitson, In charge.

W. J. Geib, Inspector and Editor.

M. J. Dunnewald, Field Assistant and Analyst.

H. W. Stewart, Field Assistant and Physicist. 


\section{TABLE OF CONTENTS}

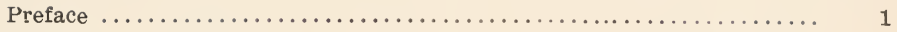

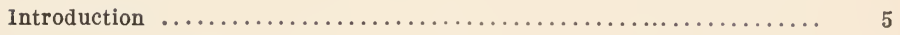

List of lakes investigated $\ldots \ldots \ldots \ldots \ldots \ldots \ldots \ldots \ldots \ldots \ldots \ldots \ldots \ldots \ldots \ldots \ldots \ldots \ldots$

Analytical key to the genera $\ldots \ldots \ldots \ldots \ldots \ldots \ldots \ldots \ldots \ldots \ldots \ldots \ldots \ldots \ldots \ldots \ldots$

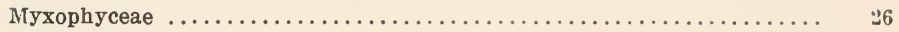

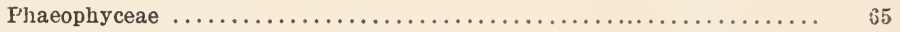

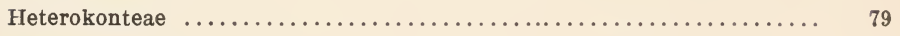

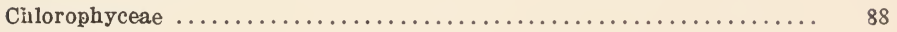





\section{PREFACE}

The general name plankton is given to the organisms whic: we reyfloating in the deeper parts of lakes and ponds; the plant individuals being designated the phytoplankton and the animal the zooplankton. Investigations have shown that there is a very special algal flora living exclusively in the plankton, in addition to the chance wanderers from the littoral, or marginal, region which do not multiply when in the plankton. These will be designated as the euplanktonts and tychoplanktonts respectively in this work. There is still another group of organisms found in lakes, namely those which thrive equally under littoral or pelagic conditions. This group will be referred to as the facultative planktonts. Attempts have been made to differentiate between organisms of these three groups by the Wests, Teiling, and others, although a different terminology has been used. Since the question of a proper habitual classification for any particular species will always be a matter of individual opinion, I have indicated at the end of the description my conception of the natural habitat of the organisms found in the lakes of this state.

It is only within the past twenty-five years that the phytoplankton has been studied, and our knowledge of the various members constituting this specialized flora has come almost exclusively from European phycologists. William West, G. S. West and Fritsch in England; Chodat and Bachmann in Switzerland; Lemmermann, Schmidle, Schröder and Volk in Germany; von Keissler, Pascher and Woloszynska in AustriaHungary; and Wesenberg-Lund in Denmark have been the chief students of European phytoplankton. The central African lakes have been investigated by G. S. West, Schmidle, and Woloszynska. G. S. West and Playfair have studied the phytoplankton of Australia. With the exception of Miss Snow's work on Lake Erie nothing was known concerning the taxonomy of North American phytoplankton at the time the present work was undertaken, the pioneer work on the microscopy of the Massachussetts and Brooklyn water supplies being of little value to the systematist since determinations were not carried beyond the genus.

These studies of Wisconsin lakes, carried out under the auspices of the Wisconsin Geological and Natural History Survey, were commenced in the fall of 1913 . Field work was continued during the summers of 
1914-15-16-17 and all lake areas of the state have been visited during the progress of the investigation. Collections have been made from the lakes around Madison and Oconomowoc during the entire season that they are open. The June, August and early September flora of the northeastern lakes is represented, while the northwestern lakes were visited for two successive seasons during August. Only single collections were made from the northern lakes so that the data for any particular one of them are undoubtedly very fragmentary.

The limits of the survey are determined by the political boundaries of the state and not by ecological or regional unity. There is a continuation of the southeastern lake group in northeastern Illinois; of the northeastern lake group in the northern peninsula of Michigan; and of the northwestern lake area in Minnesota. However, variation in depth and surface area together with variation in chemical content of Wisconsin lakes gives a sufficient range of habitat to cover conditions found in almost all other parts of the world if temperature and altitude are excluded. The cosmopolitan nature of phytoplankton, therefore, makes this work of value to the student of these microörganisms in other sections of the United States or even other continents, and he will probably find a majority of the species in any region represented in the Wisconsin flora. There is a temptation to include species that have not been observed in order to round out the work for the student in other parts of the world. This practice has been followed in certain algal floras and while it may be helpful to the general student, it causes endless confusion to the phytogeographer. Only those species are included in this flora which have been collected from the state.

Descriptions of plankton algae are scattered through a large number of periodical publications and transactions of learned societies, many with only a limited circulation, so that considerable effort has been spent in giving full and correct citations for the original descriptions. When subsequent descriptions have been better or have given more characteristic figures references are also made to them. A great deal of time has also been spent making camera lucida drawings since an accurate figure is frequently more valuable than a description. Drawings of the various species of a genus are generally on the same scale, but there has been no attempt to draw the different genera on the same scale. The finer details of cytological structure, such as the nature of the chloroplast or structure of the pyrenoid, are frequently lost in preserved material; so all of the Chlorophyceae, with the exception of the Desmidiaceae, the Phaeophyceae, Heterokonteae and the Myxophyceae, have been drawn from living material.

The original plan for the study of Wisconsin lake algae included those attached to rocky shores or lying among the macroscopic vegetation in the quieter portions of lakes in order to get the relation between the 
benthos and the plankton, but it soon became apparent that limitations of both time and space precluded an adequate presentation of the littoral flora; attention, therefore, has been confined to phytoplankton since the second season's work. The great amount of material on the phytoplankton has necessitated dividing the work into two portions; the material included in the present volume, and the Desmidiaceae and Bacillareae which are reserved for a later one. A considerable amount of work has been done already on these two groups and it is hoped that the complete report can be published shortly.

Phycologists are generally agreed on the broader principles of algal classification but naturally differ on minor details. The classification here adopted for the Myxophyceae is used almost universally. The group of flagellates with brown chromatophores is frequently considered more animal than plant. One section, the Chrysomonadineae, where there are golden brown chromatophores, seems to be sufficiently related to the Phaeophyceae to warrant placing them in a description of plankton algae and in the arrangement of the group I have followed Pascher's classification. Since Luther's establishment of the Heterokonteae, the question of whether to recognize this group as a separate class or a division of the Chlorophyceae has arisen. The evidence seems fairly clear, however, that the origin of the group is from a primitive flagellate of the Chloramoeba type and since this phylogenetic starting point is so markedly different from the phylogenetic starting point of the Chlorophyceae (the Polyblepharidaceae) I feel that the 1wo should be considered distinct classes. The classification used is that of G. S. West, although it should be noted that he considers the Heterokonteae a division of the Chlorophyceae. I have also, with a few exceptions, followed West's arrangement of the Chlorophyceae. It is hoped that the keys found in this work will prove usable. They are based solely upon characters of the species described herein; so will be of no value for those not mentioned.

During the seasons of 1916 and 1917 the field work was assisted by a grant of money from the United States Bureau of Fisheries; and the extension of these studies to the lakes of northwestern Wisconsin has thus been made possible.

The University of Wisconsin,

Department of Botany,

February, 1919. 



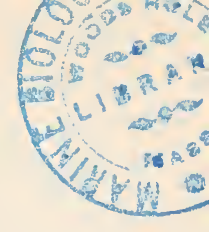

\section{IN'TRODUCTION}

Geography and geology of Wisconsin. The state of Wisconsin lies between Lake Superior, Lake Michigan and the Mississippi river and has an area of 56,066 square miles, ${ }^{\prime} r$ an area somewhat larger than England. Its greatest breadth is about 295 miles and greatest length 320 miles. Within its borders are numerous lakes, the total number probably reaching well into the thousands, with an estimated surface area of about 1500 square miles. They vary in size from small lakelets and ponds that cover but a few acres, to Lake Winnebago with an area of 215 square miles. The great majority of the lakes, however, have less than a square mile of surface area. There is likewise great variation in depth, but for the most part they are shallow since the deepest (Green Lake) has a maximum depth of 237 feet and only a few have a depth of over a hundred feet. Certain phycologists have tried to differentiate between the plankton floras of ponds (heleoplankton) and lakes (limnoplankton). The lakes of this state grade so imperceptibly from the "pond" to the "lake" type that it has been impossible to distinguish between the two. To set arbitrarily a surface area of a square mile and depth of 25 feet as the maximal limits for a pond would involve many difficulties; since the state presents such examples as Beasley Lake with a surface area of 0.019 square miles and a depth of 51 feet or Lake Winnebago with a surface area of 215 square miles and a maximum depth of 21 feet. I have, therefore, listed all bodies of water as lakes but have given, in Table 2, all available data on area and depth for those desiring to recapitulate into heleoplankton and limnoplankton.

There are, roughly speaking, three lake areas in the state; the southeastern, northwestern and northeastern, all of which owe their origin to glaciation. These lake areas are not uniformly distributed over the state since the glacier invading this region was divided into lobes and lakes are found in greatest abundance along the terminal and kettle moraines of these various lobes. The southwestern portion of the state possesses no lakes since it lies in a non-glaciated region. The southcastern lake area includes several scattered moderately sized lakes and groups of smaller lakes some of which are among the deepest in the state. The majority of them lie in a region of kames and pitted plains, where the pits and lake basins owe their origin to the burial and sub- 
sequent melting of large irregular blocks of ice. The Oconomowoc, Lauderdale and Waupaca lake groups are of this type. A few of the larger and deeper lakes, as Green and Mendota, are situated in valleys eroded by preglacial streams that were possibly modified by glacial action and then closed by the building of a morainal dam which impounded the waters of the present lake.

The northeastern lake group lies chiefly in Vilas, Oneida and Iron counties. There are hundreds of lakes in this area and their closeness of position may readily be inferred from the fact that while the largest of them, Trout Lake, covers only 6.5 square miles the $3 \pm 6$ lakes and ponds in Vilas county occupy 140 square miles or over 15 percent of the area of a county nearly as large as Rhode Island. In few parts of the world are there more lakes to the square mile. Parts of the State of Minnesota, the Province of Ontario, and Finland furnish the only parallel. These lakes are small, irregularly shaped, and connected by streams with most irregular courses. They are all glacial in origin and formed either by shallow depressions of the ground moraine, hollows in outwash plains, or damming of recessional moraines. The entire region is so deeply buried by the glacial drift that no lake is due to a damming of a preglacial valley. This entire region also contains numerous swamps (muskegs) characteristics of a poorly drained area.

The northwestern lake area lies in Barron, Polk, Burnett, Washburn, and Sawyer counties. In general it is similar to the northeastern lake area in structure and origin but the lakes do not occupy so great a portion of the land's surface. It has been suggested that some of the lakes in this region were formed before the last glacial invasion or Late Wisconsin glacial epoch. Here we find a few lakes formed by a damming of preglacial valleys; Bone, Beaverdam, and Wapagossett lakes for example.

The mean average temperature of Wisconsin varies from $6.6^{\circ} \mathrm{C}$. in the southern portion to $3.3^{\circ} \mathrm{C}$. in the northern. The state has a mean summer temperature similar to that of France, Germany, or southeastern England $\left(14.5^{\circ}\right.$ to $\left.18^{\circ}\right)$; the average winter temperature is comparable to that of northern Sweden or central Russia $\left(-5.4^{\circ}\right.$ to $\left.-8.8^{\circ}\right)$. All lakes in the state are frozen over during the winter, ice forming during November and December and lasting until March or April in the southern ones, while on some of the northern lakes ice appears in October and remains until the latter part of May. The midsummer surface temperature of the northern lakes is $18^{\circ}-24^{\circ} \mathrm{C}$. and $20^{\circ}-26^{\circ}$ in the southern lakes.

The altitude of the lakes in the northeastern part of the state varies from 1550-1700 feet above sea level; in the northwestern area 10501350 feet, and from 750 to 900 feet in the southeastern. These differences in elevation are too slight to be of any biological significance. 
Likewise differences in the amount of mean annual precipitation, which range from 28-44 inches in various parts of the state, need no discussion since rainfall in all regions is sufficient to maintain lakes at their normal level.

The underlying geological formations are, however, of prime importance and have a marked influence on the distribution of plankton organisms, especially the plankton desmids. Within the state are found areas of igneous, metamorphic, and sedimentary rocks each of which have a different direct influence on the chemical environment of the plankton organisms. The underlying rock formations of the southeastern lake area are the Niagara limestone of the Silurian; the Cincinnati shale, Galena limestone, Lower Magnesian limestone and St. Peter sandstone of the Ordovician. In the northwestern lake region is found the Cambrian Potsdam sandstone, the Ordovician Lower Magnesian limestone, together with areas of Keeweenawan trap rock and Precambrian granites. The northeastern area is entirely Precambrian granites.

Overlying all of these regions is a mantle of glacial drift some of which is local in origin while other constituents have been transported from distant regions. This ground moraine in southeastern Wisconsin varies in thickness from a few feet on hill tops to over 400 feet in the bottom of preglacial valleys. Mechanical analyses show that $13 \%$ consists of erystalline rocks transported from Canada while the remaining $87 \%$ is local sand-and limestone. In the northeastern lake area the glacial mantle varies from $75-100$ feet in thickness with a maximum depth of 350 feet at the southern boundary of the area. This glacial accumulation is not the result of one ice invasion but of several; the last, and the one which left the most material, came from the northeast and transported the conspicuous sand deposits of Vilas and northern Oneida counties from the sandstone region of northern Michigan. Previous ice invasions came from the northwest and their deposits, in some instances, have not been disturbed by succeeding invasions. None of the drift in this region is calcareous so that all soils are acid in character. The mantle of drift in the northwestern area varies from 500 to a few feet in thickness and is composed of material from granitic and sandstone regions. There is, however, a certain amount of lime in the drift at the southern limit of the lake area.

Chemical composition of the lake waters. Birge and Juday* have made investigations on the chemical composition of the waters of Wisconsin lakes in connection with their biochemical studies. They divide the waters into three general classes; soft, medium, and hard. These

\footnotetext{
* Birge, E. A. and Juday, C. The inland lakes of Wisconsin. The dissolvéd gases of the water and their biological significance. Bull. 22 Wis. Geol. and Nat. Hist. Survey. (Sci. Ser. 7.) pp. 1-259. 1911.
} 
varying degrees of hardness are due to the combination of the carbon dioxide with calcium and magnesium to form carbonates, the fixed $\left(\mathrm{CaCO}_{3}\right.$ and $\left.\mathrm{MgCO}_{3}\right)$ and the half-bound $\left(\mathrm{CaCO}_{3} \cdot \mathrm{H}_{2} \mathrm{CO}_{3}\right.$ and $\mathrm{MgCO}_{3} \cdot \mathrm{H}_{2} \mathrm{CO}_{3}$ ). In neutral and acid lakes the two types of carbon dioxide are present in equal amounts but in alkaline lakes there is an excess of fixed carbon dioxide. This is due to the ability of the chlorophyll bearing organisms to draw upon the half-bound carbon dioxide as a source of supply after the disappearance of the free carbon dioxide. The amounts of magnesium and calcium vary from lake to lake and there is an almost continuous series from those having the softest waters to those having the hardest. They consider those lakes whose average fixed carbon dioxide does not exceed 5 cc. per liter as soft water lakes, while medium waters have 6-22 cc. of carbon dioxide per liter and the hard waters from 23-50 cc. per liter. The carbon dioxide content varies with the depth at which the sample is taken and also with the season of the year; some of the medium class lakes, for example, have a sufficiently low content at times to qualify as soft water lakes. All of the soft and medium waters, with the exception of Devils lake in Sauk county, are located in the northeastern and northwestern lake areas and many of them have sufficient free carbon dioxide to give an acid reaction with phenolphthalein. The hardwater lakes are all in the southeastern area and the upper stratum in them is alkaline to phenolphthalein for the greater part of the year.

Aside from the question of the hardness of the water complete mineral analyses of a few lakes are also available. These results are embodied in Table 1 and represent average conditions. They are taken from the data given by Birge and Juday and their data show that there is a seasonal variation and a vertical variation in the amounts of certain elements present. These variations in vertical distribution are well shown in their Fig. 7, p. 106 (l. c.) The lakes of southeastern Wisconsin contain a rich flora of Chlorophyceae, Myxophyceae and Phaeophyceae, both in quantity and quality. In the northern lake areas the total volume of the plankton is, generally speaking, considerably smaller and quite different in character. These lakes have a considerable desmid flora in many instances, while with the exception of one or two species desmids are not found in the hard waters of the southeastern region. The volume of phytoplankton that can be produced in a lake is primarily dependent upon the available supply of carbon dioxide for photosynthesis. In the northern lakes this supply is chiefly the carbon dioxide dissolved in the water but in the southern lakes there is in addition considerable quantities of half-bound carbon dioxide which may be drawn upon after the free carbon dioxide is exhausted. It is not surprising, therefore, that the southern lakes with greater supplies of potential food materials have a greater production 
of algae. There are certain factors modifying the growth of algae in hard water lakes; in those deep ones which become thermally stratified in the summer most of the algae are restricted to the epilimnion. The thickness of the epilimnion is in part dependent upon the size and shape of the lake, since the wind is more effective in keeping water in circulation on large surfaces. Algae are continually sinking to the bottom and giving rise to carbon dioxide and nitrogenous products. In the deep

TABLE 1.-Results of mineral analyses stated in parts per million.

These show average content of varbous depths and at different dates.

\begin{tabular}{|c|c|c|c|c|c|c|c|c|c|c|}
\hline & $\mathrm{SiO}_{2}$ & $\begin{array}{l}\mathrm{Fe}_{2} \mathrm{O}_{3} \\
\mathrm{Al}_{2} \mathrm{O}_{3}\end{array}$ & $\mathrm{Ca}$ & $\mathrm{Mg}$ & $\mathrm{Na}$ & K & $\mathrm{CO}_{3}$ & $\mathrm{HCO}_{3}$ & $\mathrm{SO}_{4}$ & $\mathrm{Cl}$ \\
\hline Devils.... & 2.2 & 0.7 & 3.2 & 1.1 & .... & $\ldots$. & 1.0 & 8.1 & 8.1 & 8.2 \\
\hline Trout... & 13.0 & 1.1 & 6.7 & 2.5 & 0.8 & 0.3 & 0.0 & 28.0 & 6.4 & 3.0 \\
\hline Kawaguesaga.... & 16.5 & 6.2 & 7.2 & 2.8 & 2.6 & 1.7 & 0.0 & 37.0 & 7.9 & 2.7 \\
\hline Owen.... & 9.9 & 2.7 & 13.0 & 3.6 & ..... & $\ldots$. & 0.5 & 33.3 & 0.0 & 1.9 \\
\hline Rainbow..... & 17.5 & 2.2 & 22.2 & 15.5 & 2.3 & 3.3 & 4.0 & 105.0 & 8.9 & 4.3 \\
\hline Mendota ........... & 4.4 & 1.4 & 23.3 & 22.7 & 3.7 & 2.2 & 2.5 & 105.2 & 13.5 & 3.0 \\
\hline Geneva........ & 9.5 & 1.1 & 20.7 & 26.9 & 4.4 & 2.5 & 3.7 & 110.5 & 13.2 & 4.8 \\
\hline Okauchee..... & 17.6 & 1.5 & 34.3 & 25.9 & 3.2 & 1.4 & 0.0 & 66.0 & 13.9 & 1.9 \\
\hline Beasley ...... & 16.5 & 1.5 & 38.9 & 21.8 & 2.4 & 2.0 & 1.5 & 111.0 & 2.0 & 3.1 \\
\hline
\end{tabular}

lakes these products of decay are chiefly in the hypolimnion and are not immediately available for reutilization by other algae. In shallow lakes without thermal stratification these products are immediately available for the vegetative activities of algae. Shallow lakes, therefore, support proportionally larger algal floras. The restriction of the desmids to the soft water lakes was first pointed out by the Wests and their observations have been confirmed in Wisconsin (Birge and Juday, l. c. p. 138). An examination of the chemical analyses of such soft water lakes as Devils, Trout and Kawaguesaga (Table 1) shows that in these lakes which contain numerous desmids the calcium and magnesium content is relatively small. The influence of calcium and magnesium on the distribution of desmids may be that of a direct inhibition of growth or the absence of these elements may permit an acid condition which is favorable for the growth of desmids. Data on organic matter and distribution of nitrogen in lakes of the state are lacking. The scarcity or abundance of available nitrogen is doubtless an important factor in the volume of algae produced in a lake, and it is a well known fact that as regions become more thickly settled and drainage entering the lake becomes richer in nitrogenous material the growth of plankton algae becomes more luxuriant. 
Methods of collection and study. All plankton collections have been made with nets. In general both the bolting silk net and the cotton dise net were used. The bolting silk net of No. 20 bolting cloth (new No. 25) is that described by Juday*. The cotton disc net is made by attaching a filter designed for purifying drinking water (Jones Modern Filter made by the Jones Mfg. Co., Boston, Mass.) to the bottom of an eighteen inch cone of canvas whose mouth is held open by a light metal ring ten inches in diameter. In using this filter a special cotton disc supplied by the manufacturer is placed in the filter and the whole apparatus drawn through the water. The algae collect on the disc and when there is a sufficient accumulation the disc is taken from the filter and shaken in a bottle with a small amount of water which removes the algae. This net catches many of the smaller organisms that pass through the bolting silk (the nannoplankton) and it is also very useful in obtaining samples by dipping when no boat is available. Whenever possible samples have been gathered by towing the nets at the surface and all collections have been made in the deep parts of all lakes to avoid, as far as possible, the littoral flora. No attempt has been made to study the vertical distribution of the algae in any lake.

In studying the flora of any region a field laboratory was established and with that as a center excursions were made to the surrounding lakes. By traveling from lake to lake in an automobile collections could be made in the morning and the material studied the same afternoon and the following day. In the northeastern lake area where there are no roads in many cases, but where lakes are close together, they can be visited by portaging a canoe from lake to lake. Collections have been made from row boats, where they were obtainable, but in a few instances collections had to be made by repeatedly dipping the net after wading to where the water was $3-4$ feet deep or from rafts. Upon returning to the temporary laboratory equipped with compound microscope, camera lucida, and drawing materials, the living specimens were studied and numerous pencil camera lucida drawings made of all doubtful, interesting, or rare organisms, together with notes on occurrence and ocular micrometer measurements of known forms. No observations were made on desmids or diatoms at this time. The study of the Chlorophyceae, Myxophyceae and Phaeophyceae in the living condition is particularly important since many of them do not preserve well and certain features such as cilia, chloroplasts, and contractile vacuoles are lost when material is preserved. All drawings of one species are mounted on the same sheet and corresponding notes on another. These are then filed in species and genus covers in the usual

* Juday, C. Limnological apparatus. Trans. Wis. Acad. Sci. Arts \& Lett. $18^{3}$ : $\quad 566-592.1916$. 
manner for herbarium specimens so that all data on any particular species are immediately accessible. The figures for the plates of this work have been redrawn from camera lucida sketches made in field laboratories. The confined space of a vial is not favorable for algae and the more delicate forms, as Uglenopsis, frequently go to pieces after standing a few hours. It is impossible to have the vials uncorked while transporting them from station to station but they should be opened immediately on return to field headquarters. I have also found it helpful to keep them as cool as possible and have stored them in hotel refrigerators until ready to make observations. Formalin has proven a satisfactory means of preserving the desmids and diatoms until their study can be taken up during the winter months.

The following list of simple reagents is helpful in studying the various structures of living algae. Cilia of motile forms are more easily seen when the cells have been rendered immobile by mounting in a $1 \%$ cocaine solution. Mounting in a dilute aqueous acid fuchsin also helps. Pyrenoids can be recognized by the grouping of the starch grains when the latter have been stained with iodine. It is difficult to strain pyrenoids of living cells. Gelatinous envelopes are best demonstrated by Frrera's method of mounting in dilute India ink which gives the colcrless envelope the appearance of a halo around the cells in contrast to the dark background of water containing the ink. Nuclei can be demonstrated by Strasburger's solution of methyl green in 1\% acetic acid. Simple microchemical tests are Sudan III for fats, iodine for starch, zinc chloriodide for cellulose, and Ruthineum Red for pectin.

Lakes studied. The following table gives a list of lakes in the state from which plankton samples have been taken. All known hydrographic maps, morphometric data, general descriptions of many lakes and general maps of the various lake areas have been given by Birge and Juday* so that any one wishing further data concerning a particular lake is referred to their work. They have not, however, mapped or discussed many of the smaller lakes of the northern regions. Since most of the lakes in the state were named by the settlers of the region considerable poverty of vocabulary is noticed and Round, Mud, Devils, Long, and Sand are repeated many times. In other instances Indian (Chippewa) names have been retained as the white man settled the region. In these also there is a certain amount of duplication and Sishebogema (lake with many bays) or Pokegama (side or branch lake) may be eited as examples. It is too bad that these names have not been retained to a greater extent, but certain of the English names like Razorback, Crawlirg Stone, Lost Canoe, Tenderfoot or Fishtrap are not

* Birge, E. A. and Juday, C. The inland lakes of Wisconsin. Bull. 27: Wis. Geol. \& Nat. Hist. Survey. (Sci. Ser. 9). pp. 1-137. 1914. 
without interest. This is not the place, however, for the legends on the origin of these peculiar names nor for a discussion of the occurrence of several French names in the list. In order to avoid misunderstanding the town and range in which the lake occurs is given. When more than one lake with the same name has been visited, a serial number has been added and both the lake name and serial number are used in giving stations for the various algae. 
TABLE 2.-Table giving available data on location and size of lakes visited during the course of this investigation. The first column refers to the page on which a map of the lake may be found in Birge and Juday, The inland lakes of Wisconsin, the hydrography and morphometry. Bull. 27. Wis. Geol. and Nat. Hist. Survey.

\begin{tabular}{|c|c|c|c|c|c|c|c|c|}
\hline $\begin{array}{c}\text { Page } \\
\text { map- } \\
\text { ped }\end{array}$ & Lake & County & Town & Range & $\begin{array}{l}\text { Length } \\
\text { (Miles) }\end{array}$ & 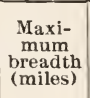 & $\begin{array}{l}\text { Maxi- } \\
\text { mum } \\
\text { depth } \\
\text { (Feet) }\end{array}$ & $\begin{array}{c}\text { Area } \\
\text { (Acres) }\end{array}$ \\
\hline & Adelaide.... & Vilas.. & $43 N$ & $5 \mathrm{E}$ & .47 & .32 & 68.9 & 45.0 \\
\hline .... & Amicoy ....... & Rusk... & $34 \mathrm{~N}$ & $8 W$ & 1.06 & .30 & ..... & ...... \\
\hline 120 & Balsam..... & Polk.... & $34 \mathrm{~N}$ & $17 \mathrm{~W}$ & 3.00 & 1.00 & 18.0 & $1,785.6$ \\
\hline & Bass (1)... & Vilas... & $40 N$ & $11 \mathrm{E}$ & .50 & .24 & $\cdots$ & ...... \\
\hline & Bass (2)... & Vilas... & $42 \mathrm{~N}$ & $6 \mathbf{E}$ & .93 & irr. & & \\
\hline & Bass (3)... & Burnett. . & $40 N$ & $14 \mathrm{~W}$ & . & & & \\
\hline & Bear (1)...... & Barron.... & $34 N$ & $14 \mathrm{~W}$ & .45 & .40 & & ...... \\
\hline & Bear (2)..... & Polk........ & $33 N$ & $17 \mathrm{~W}$ & .88 & .59 & & ..... \\
\hline 120 & Bear $(3) \ldots$ & Barron- & $36 \mathrm{~N}$ & $12 \mathrm{~W}$ & 4.50 & 1.00 & & \\
\hline ...... & Bear Trap.... & Polk ........... & $33 N$ & $17 \mathrm{~W}$ & 1.05 & .48 & ...... & ....... \\
\hline $10 \frac{1}{2}$ & Beasley..... & Waupaca.. & $21 \mathrm{~N}$ & $11 \mathrm{E}$ & .25 & .10 & 51.2 & 13.5 \\
\hline$\cdots \cdots$ & Beaver (1).... & Vilas.... & $44 \mathrm{~N}$ & $5 E$ & .44 & .25 & .... & ..... \\
\hline 40 & Beaver (2) .... & Waukesha & $8 \mathrm{~N}$ & $18 \mathrm{E}$ & 1.10 & .44 & 49.0 & 305.4 \\
\hline 120 & Beaverdam... & Barron.. & $\begin{array}{l}35 \mathrm{~N} \\
36 \mathrm{~N}\end{array}$ & $\begin{array}{l}14 \mathrm{~W} \\
13 \mathrm{~W}\end{array}$ & 3.80 & .75 & 91.9 & $1,267.2$ \\
\hline ....... & Bettine......... & Vilas..... & $43 N$ & $7 \mathrm{E}$ & .75 & .56 & 年 & $\cdots \cdot$ \\
\hline 120 & Big................... & Polk...... & $32 \mathbf{N}$ & $18 \mathrm{~W}$ & .80 & .65 & $\cdots$ & ...... \\
\hline $1: 0$ & Big Butternut... & Polk........ & $36 \mathrm{~N}$ & $17 \mathrm{~W}$ & 1.20 & .60 & 21.3 & 384.0 \\
\hline 120 & Big McKenzie.... & Burnett... & $40 N$ & $14 \mathrm{~W}$ & 2.25 & $1.0 \mathrm{~J}$ & $\cdots$ & ........ \\
\hline 116 & Big St. Germain.. & Vllas...... & $40 N$ & $8 \mathbf{E}$ & 2.62 & 1.25 & . & ........ \\
\hline 116 & Birch (1)....... & Vilas........ & $43 N$ & $5 E$ & 1.50 & .74 & …..... & ........ \\
\hline 120 & Birch (2)......... & Washburn & $37 N$ & $10 \mathrm{~W}$ & .90 & .70 & 57.4 & 243.2 \\
\hline 120 & Birch Island.... & Burnett.. & $40 N$ & $14 \mathrm{~W}$ & 2.10 & irr. & & ..... \\
\hline & Blake......... & Polk...... & $35 N$ & $16 \mathrm{~W}$ & 1.90 & irr. & & ....... \\
\hline$\cdots$ & Bloom .......... & Burnett.. & $37 \mathrm{~N}$ & $18 \mathrm{~W}$ & ..... & .... & & \\
\hline$\cdots \cdots$ & Blue Gill........ & Vilas...... & $43 N$ & $7 \mathrm{E}$ & .12 & .09 & $\cdots \cdots$ & $\cdots \ldots \ldots$ \\
\hline 120 & Bone......... & Polk....... & $\begin{array}{l}35 \mathrm{~N} \\
36 \mathbf{N}\end{array}$ & $16 \mathrm{~W}$ & 4.80 & 1.00 & 49.2 & $2,054.4$ \\
\hline 116 & Boulder ..... & Vilas....... & $42 \mathrm{~N}$ & $7 \mathrm{E}$ & 2.25 & 1.20 & 19.7 & 614.4 \\
\hline 74 & Browns...... & Racine.... & $\frac{2 N}{3 N}$ & $19 E$ & 1.25 & .75 & 23.0 & 390.4 \\
\hline …... & Bullhead .... & Vilas....... & $40 \mathrm{~N}$ & $6 \mathbf{E}$ & .31 & .26 & ...... & ...... \\
\hline 75 & Camp......... & Kenosha...... & $1 N$ & $20 \mathrm{E}$ & 1.50 & 1.00 & 19.7 & 256.0 \\
\hline …... & Canteen ...... & Vilas........ & $45 \mathrm{~N}$ & $7 \mathrm{E}$ & .31 & .17 & $\cdots \cdots$ & ...... \\
\hline 116 & $\begin{array}{l}\text { Carroll................ } \\
\text { Carson (see Flora) }\end{array}$ & Vilas.... & $\begin{array}{l}39 N \\
40 N\end{array}$ & $7 \mathrm{E}$ & 1.30 & .47 & 23.0 & 288.0 \\
\hline
\end{tabular}


TABLE 2.-(Continued)

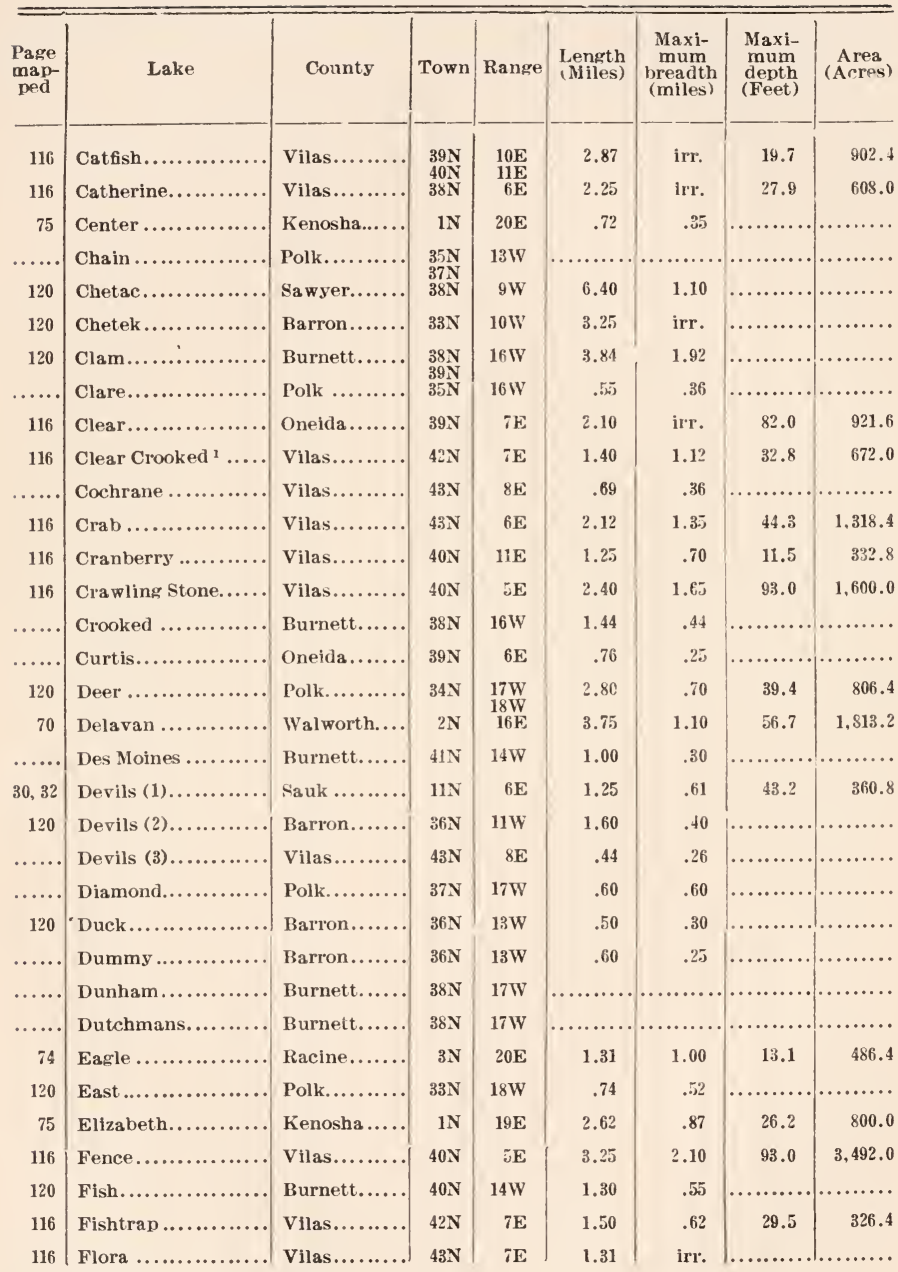

'Listed as Clear Lake by Birge and Juday. 
TABLE 2.-(Continued)

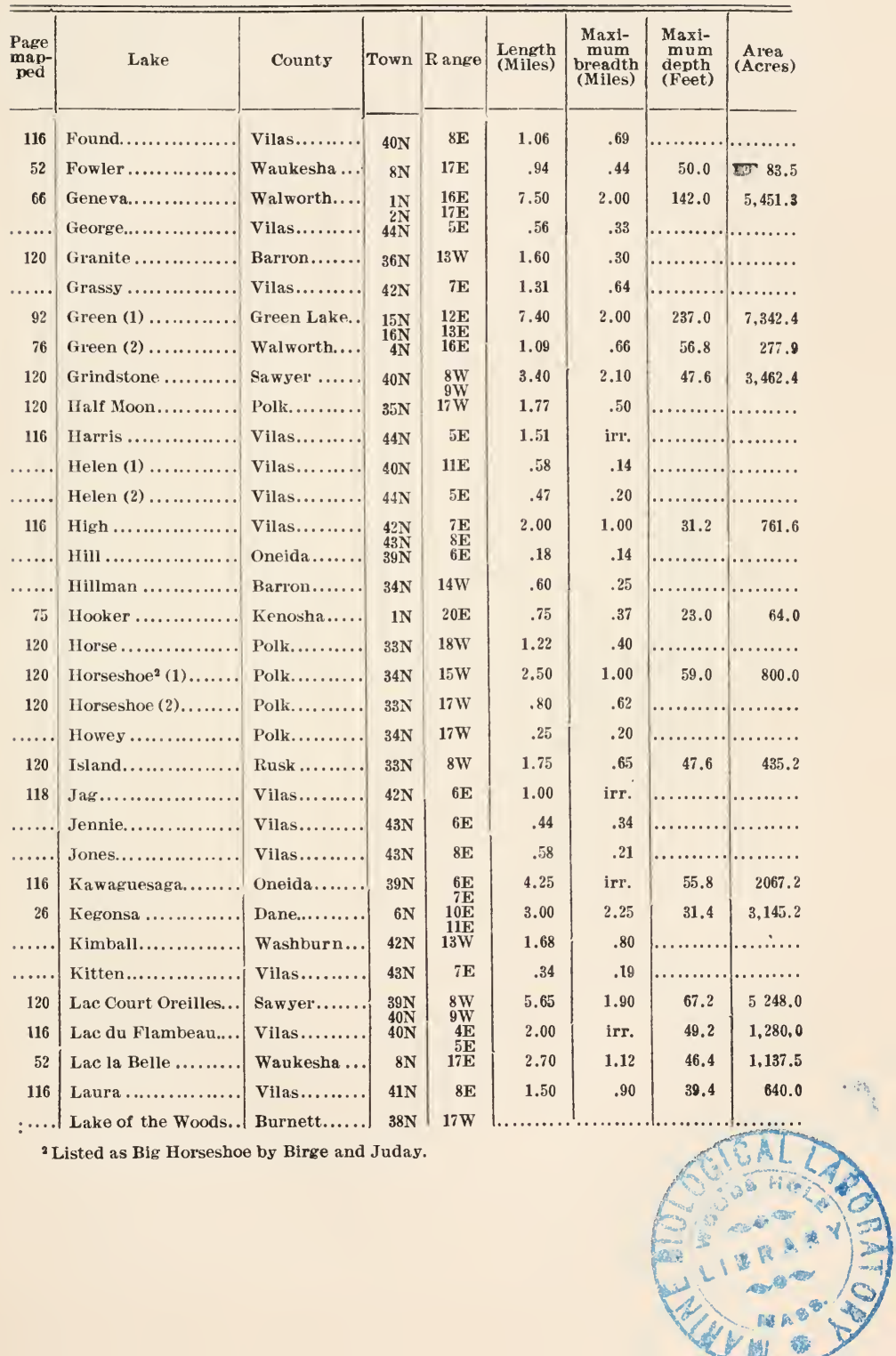




\section{TABLe 2-(Continued)}

\begin{tabular}{|c|c|c|c|c|c|c|c|c|}
\hline $\begin{array}{c}\text { Page } \\
\text { map- } \\
\text { ped }\end{array}$ & Lake & County & Town & Range & $\begin{array}{l}\text { Length } \\
\text { (Miles) }\end{array}$ & $\begin{array}{c}\text { Maxi- } \\
\text { mum } \\
\text { breadth } \\
\text { (Miles) }\end{array}$ & $\begin{array}{l}\text { Maxi- } \\
\text { mum } \\
\text { depth } \\
\text { (Feet) }\end{array}$ & $\begin{array}{c}\text { Area } \\
\text { (Acres) }\end{array}$ \\
\hline & Lily ....... & Burnett... & $41 N$ & $14 \mathrm{~W}$ & & & & \\
\hline & 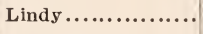 & Burnett... & $40 \mathrm{~N}$ & $14 \mathrm{~W}$ & & & & \\
\hline & Little Bass (1)....... & Vilas......... & $42 N$ & $6 \mathrm{E}$ & .28 & .19 & & \\
\hline$\cdots$ & Little Bass (2)...... & Polk....... & $34 N$ & $17 \mathrm{~W}$ & $\cdots \cdot$ & 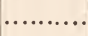 & & \\
\hline & Little Bear........... & Vilas.... & $43 N$ & $6 \mathrm{E}$ & .69 & .44 & & \\
\hline & Little Butternut.... & Polk....... & $36 \mathrm{~N}$ & $17 \mathrm{~W}$ & .60 & .35 & & \\
\hline & Little Crooked ....... & Vilas...... & $42 \mathrm{~N}$ & $6 \mathrm{E}$ & 1.06 & irr. & & \\
\hline & Little Doctor........ & Burnett...... & $38 \mathrm{~N}$ & $17 \mathrm{~W}$ & .45 & .30 & & \\
\hline$\cdots \cdots \cdot$ & Little Rice (1)....... & Rusk.......... & $33 \mathrm{~N}$ & $8 W$ & .70 & .40 & & \\
\hline 118 & Little Rice (2)... & Vilas....... & $42 N$ & $7 \mathrm{E}$ & .76 & .38 & & \\
\hline 120 & Little Wood.......... & Burnett...... & $38 \mathrm{~N}$ & $18 W$ & .82 & .48 & & \\
\hline$\cdots \cdots \cdot$ & Long (1)............... & Burnett... & $41 N$ & $14 \mathrm{~W}$ & 1.85 & .35 & & \\
\hline 120 & Long (2).,........ & Polk....... & $34 \mathrm{~N}$ & $17 \mathrm{~W}$ & 1.70 & .55 & 24.6 & 384.0 \\
\hline$\cdots \cdots$ & Long (3)......... & Vilas...... & $40 N$ & $5 \mathbf{E}$ & 1.40 & .60 & 55.8 & 448.0 \\
\hline 104 & Long (4)......... & Waupaca .... & $21 N$ & $11 \mathrm{E}$ & .94 & .36 & 77.7 & 108.4 \\
\hline$\cdots \cdots \cdot$ & Loon...$\ldots \ldots \ldots \ldots$ & Barron........ & $34 \mathrm{~N}$ & $14 \mathrm{~W}$ & 1.00 & .45 & & \\
\hline 116 & Lost................ & Vilas....... & $40 N$ & $8 \mathrm{E}$ & 1.69 & .86 & ?... & ........... \\
\hline 118 & Lost Canoe............ & Vilas....... & $42 \mathrm{~N}$ & $7 \mathrm{E}$ & 1.25 & .38 & 41.0 & 204.8 \\
\hline 120 & Loveless .............. & Polk........ & $34 N$ & $17 \mathrm{~W}$ & 1.00 & .32 & 21.3 & 153.6 \\
\hline$\cdots \cdots \cdot$ & Lynx............ & vilas......... & $43 \mathrm{~N}$ & $7 \mathrm{E}$ & .75 & .66 & & .... \\
\hline$\cdots \cdots$ & Marion............... & Vilas.......... & $44 N$ & $5 \mathbf{E}$ & .37 & .19 & & \\
\hline 104 & Mar1 $\ldots . . . . . . . . . .$. & Waupaca .... & $21 \mathrm{~N}$ & $11 \mathrm{E}$ & .31 & .19 & 60.6 & 21.3 \\
\hline 75 & Mary.................. & Kenosha.... & $1 \mathrm{~N}$ & $19 \mathrm{E}$ & 1.20 & .70 & 26.2 & 275.2 \\
\hline 12 & Mendota ............... & Dane....... & $\begin{array}{l}7 \mathbf{N} \\
8 \mathbf{N}\end{array}$ & $9 \mathrm{E}$ & 5.90 & 4.60 & 84.0 & $9,729.8$ \\
\hline & Mercer.............. & Oneida........ & $39 \mathrm{~N}$ & $5 \mathbf{E}$ & 1.30 & .69 & & \\
\hline ..... & Meronk............... & Burnett...... & $40 \mathrm{~N}$ & $14 \mathrm{~W}$ & & & & \\
\hline ...... & Meta.............. & Vilas.......... & $40 \mathrm{~N}$ & $11 \mathrm{E}$ & .64 & .26 & . $\ldots \ldots \ldots$ & $\cdots \cdots \cdots$ \\
\hline 76 & Middle............. & Walworth.... & $4 \mathrm{~N}$ & $16 \mathrm{E}$ & 1.60 & .45 & 50.0 & 284.0 \\
\hline 120 & Middle McKenzie ${ }^{3} .$. & Burnett... & $40 N$ & $14 \mathrm{~W}$ & 1.10 & .90 & $\cdots \cdots \cdots \cdots$ & $\cdots \cdots$ \\
\hline 76 & MI11 ................. & Walworth.... & $4 N$ & $16 \mathrm{E}$ & .75 & .49 & 50.0 & 296.4 \\
\hline 20 & Monona..... & Dane..... & $7 \mathrm{~N}$ & $\begin{array}{r}9 \mathbf{E} \\
10 \mathbf{E}\end{array}$ & 4.16 & 2.40 & 74.0 & $3,482.7$ \\
\hline$\cdots \cdots$ & Mud (1) .............. & Polk ......... & $34 N$ & $17 \mathrm{~W}$ & .66 & .28 & .... & ........ \\
\hline$\cdots \cdots$ & Mud (2) .............. & Vilas..... & $40 \mathrm{~N}$ & $5 \mathbf{E}$ & .81 & .56 & .... & ... \\
\hline 114 & Mud (3) ........ & Vilas......... & $39 \mathrm{~N}$ & $7 \mathbf{E}$ & .87 & .36 & & ... \\
\hline
\end{tabular}

' Listed as McKenzie lakes. 
TABLE 2-(Continued)

\begin{tabular}{|c|c|c|c|c|c|c|c|c|}
\hline $\begin{array}{c}\text { Page } \\
\text { man- } \\
\text { ped }\end{array}$ & Iake & County & Town & Range & $\begin{array}{l}\text { Length } \\
\text { (Miles) }\end{array}$ & $\begin{array}{c}\text { Maxi- } \\
\text { mum } \\
\text { breadth } \\
\text { (Miles) }\end{array}$ & $\begin{array}{l}\text { Maxi- } \\
\text { mum } \\
\text { depth } \\
\text { (Feet) }\end{array}$ & $\begin{array}{l}\text { Area } \\
\text { (Acres) }\end{array}$ \\
\hline \multirow[t]{2}{*}{104} & Niud (4)... & Waupaca & $21 N$ & $11 \mathrm{E}$ & .13 & .06 & 32.0 & 9.7 \\
\hline & Mudhen.... & Burnett... & $38 \mathrm{~N}$ & $17 \mathrm{~W}$ & 1.68 & 1.10 & & $\ldots$. \\
\hline 116 & Muskallonge... & Vilas.... & $41 N$ & $7 \mathrm{E}$ & 1.93 & irr. & & \\
\hline 120 & Nancy ...... & Washburn.. & $42 \mathrm{~N}$ & $13 \mathrm{~W}$ & 2.00 & 1.25 & . & ... \\
\hline 54 & Naga wicka ..... & Waukesha.. & $7 \mathrm{~N}$ & $18 \mathrm{E}$ & 2.75 & 1.12 & 94.4 & 917.6 \\
\hline 54 & Nashotah (Upper)... & Waukesha.. & $7 \mathrm{~N}$ & $1 i \mathrm{E}$ & .81 & .40 & 57.2 & 136.7 \\
\hline \multirow[t]{2}{*}{54} & Nashotah (Lower) .. & Waukesha.. & $7 \mathrm{~N}$ & $17 \mathrm{E}$ & .79 & .25 & 46.2 & 100.3 \\
\hline & Nell................. & Vilas......... & $44 N$ & $5 \mathrm{E}$ & .46 & .15 & ....... & ....... \\
\hline 54 & Nemahbin (Upper).. & Waukesha.. & $7 \mathrm{~N}$ & $17 \mathrm{E}$ & 1.05 & .56 & 62.0 & 271.1 \\
\hline \multirow[t]{2}{*}{54} & Nemahbin (Lower).. & Waukesha. & $7 \mathrm{~N}$ & $17 \mathrm{E}$ & .93 & .60 & 35.2 & 265.5 \\
\hline & Nicaborne.......... & Burnett... & $41 N$ & $14 \mathrm{~W}$ & … & & & \\
\hline \multirow[t]{4}{*}{116} & No Mans....... & Vilas....... & $44 N$ & $5 E$ & 1.00 & .69 & & \\
\hline & North Twin.... & Polk........ & $33 N$ & $16 \mathrm{~W}$ & .92 & .30 & & \\
\hline & Number One.... & Sawyer .... & $37 N$ & $9 W$ & .25 & .18 & & \\
\hline & Oak ............. & Burnett...... & $40 \mathrm{~N}$ & $14 \mathrm{~W}$ & .70 & .45 & $\cdots$ & ....... \\
\hline 46 & Oconomuwoc.... & Waukesha... & $i N$ & $17 \mathrm{E}$ & 1.75 & .85 & 62.6 & 631.3 \\
\hline \multirow[t]{2}{*}{46} & Okanchee........ & Waukesha... & $8 \mathrm{~N}$ & $\begin{array}{l}17 \mathrm{E} \\
18 \mathrm{E}\end{array}$ & 2.37 & 1.80 & 94.0 & 1,$0 ; 7.0$ \\
\hline & Old Taylors.... & Waupaca.... & $22 \mathrm{~N}$ & $11 \mathrm{E}$ & & & & \\
\hline 104 & Otter............. & Waupaca.... & $22 \mathrm{~N}$ & $11 \mathrm{E}$ & .40 & .03 & 40.0 & 14.5 \\
\hline 120 & Owen........... & Bay field .... & $\begin{array}{l}44 N \\
43 N\end{array}$ & $7 \mathrm{~W}$ & 6.25 & irr. & 88.6 & $2,032.0$ \\
\hline 75 & Paddock........... & Kenosha.... & in & $\therefore \mathrm{EE}$ & .62 & .37 & 31.0 & 9.5 \\
\hline 116 & Palmer............ & Vilas......... & $43 N$ & $8 \mathrm{E}$ & 1.75 & 1.25 & 14.8 & 614.4 \\
\hline 116 & Pardee........... & Vilas.......... & $44 \mathrm{~N}$ & $4 \mathrm{E}$ & .94 & .87 & ….... & - $\cdots \cdots \cdots$ \\
\hline \multirow[t]{2}{*}{63} & Pewaukee... & Waukesha... & $7 N$ & $\begin{array}{l}18 \mathrm{E} \\
19 \mathrm{E}\end{array}$ & 4.30 & 1.20 & 45.0 & $2,298.0$ \\
\hline & Pike.......... & Polk.......... & $33 \mathrm{~N}$ & $16 \mathrm{~W}$ & 1.18 & .30 & .... & ...... \\
\hline \multirow[t]{3}{*}{40} & Pine (1)...... & Waukesha... & $8 \mathbf{N}$ & $18 \mathrm{E}$ & 2.30 & 1.05 & 90.0 & 7555.7 \\
\hline & Pine (z)............ & Polk........ & 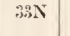 & $17 \mathrm{~W}$ & .66 & .28 & & \\
\hline & Pine Tree............. & Polk......... & $32 \mathrm{~N}$ & $16 \mathrm{~W}$ & .92 & irr. & $\ldots \ldots$ & (n...... \\
\hline 116 & Plum............ & Vilas........ & $41 N$ & $7 \mathrm{E}$ & 4.20 & 1.25 & 50.8 & $1,088.0$ \\
\hline 120 & Pokegama (i) ..... & Washburn.... & $42 \mathrm{~N}$ & $12 \mathrm{~W}$ & 2.40 & .60 & 23.0 & 505.6 \\
\hline 116 & Pokegama (2) ..... & Vilas....... & $\begin{array}{ll}40 N \\
41 N\end{array}$ & $5 \mathbf{E}$ & 3.25 & 1.80 & 42.6 & $1,216.0$ \\
\hline \multirow[t]{2}{*}{120} & Pokegama (3) .... & Barron... & $33 N$ & $10 \mathrm{TT}$ & 3.50 & .70 & & \\
\hline & Poor Farm..... & Polk........... & $33 \mathrm{~N}$ & $16 \mathrm{~W}$ & & & & $\cdots \cdots$ \\
\hline 104 & Pope ........... & Waupaca..... & $21 N$ & $11 \mathrm{E}$ & .22 & .11 & 40.6 & 16.2 \\
\hline 120 & Poplar ............... & Polk.......... & $32 N$ & $18 \mathrm{~W}$ & .72 & .38 & ........ & ......... \\
\hline
\end{tabular}


Table 2.-(Continued)

\begin{tabular}{|c|c|c|c|c|c|c|c|c|}
\hline $\begin{array}{l}\text { Page } \\
\text { map- } \\
\text { ped }\end{array}$ & Lake & County & Town & Range & $\begin{array}{l}\text { Length } \\
\text { (Miles) }\end{array}$ & $\begin{array}{c}\text { Maxi- } \\
\text { mum } \\
\text { breadth } \\
\text { (Miles) }\end{array}$ & $\begin{array}{l}\text { Maxi- } \\
\text { mum } \\
\text { depth } \\
\text { (Feet) }\end{array}$ & $\begin{array}{l}\begin{array}{l}\text { Area } \\
\text { (Acres) }\end{array} \\
\text { (A) }\end{array}$ \\
\hline 8 & Poygan... & Waushara. & $19 \mathrm{~N}$ & $13 \mathrm{E}$ & 7.70 & 3.50 & 10.8 & $10,992.2$ \\
\hline 120 & Prairie..... & Barron..... & $33 \mathrm{~N}$ & $11 \mathrm{w}$ & 6.50 & .70 & & ........ \\
\hline 104 & Rainbow (1)... & Waupaca... & $22 \mathrm{~N}$ & $11 E$ & .62 & .55 & 95.1 & 137.5 \\
\hline 116 & Rainbow (2) .. & Vilas..... & $44 \mathrm{~N}$ & $5 \mathbf{E}$ & .63 & .44 & & ...... \\
\hline 116 & Razorback.... & Vilas....... & $41 \mathrm{~N}$ & $8 \mathbf{E}$ & 1.10 & .90 & 31.1 & 352.0 \\
\hline & Red Bass... & Vilas... & $42 \mathrm{~N}$ & $7 \mathrm{E}$ & .40 & .13 & & ...... \\
\hline & Reserve.... & Sawyer... & $39 \mathrm{~N}$ & $8 \mathrm{~W}$ & 1.00 & .55 & & \\
\hline & Rice (1) .... & Barron... & $35 \mathrm{~N}$ & $11 \mathrm{~W}$ & 2.75 & .60 & & \\
\hline & Rice (2) ...... & Vilas..... & $42 \mathrm{~N}$ & $6 \mathrm{E}$ & .45 & .30 & & \\
\hline & Rock ........ & Vilas..... & $44 N$ & $5 \mathbf{E}$ & 1.12 & .37 & & \\
\hline & Rooney .... & Burnett... & $40 \mathrm{~N}$ & $14 \mathrm{~W}$ & & & & \\
\hline & Rose.......... & Vilas..... & $40 \mathrm{~N}$ & iE & 1.14 & .25 & & ..... \\
\hline & Round (1)... & Vilas....... & $43 N$ & $6 \mathbf{E}$ & .62 & .40 & & $\ldots \ldots$ \\
\hline & Round (2)... & Polk...... & $33 \mathrm{~N}$ & $18 \mathrm{~W}$ & .58 & .41 & & \\
\hline ... & Round (3).. & Polk...... & $32 \mathrm{~N}$ & $17 \mathrm{WV}$ & .26 & .20 & & ...... \\
\hline 104 & Round (4)... & Waupaca & $22 \mathrm{~N}$ & $11 \mathrm{E}$ & .55 & .35 & 66.6 & 106.2 \\
\hline .... & Rozen ........ & Vilas..... & $40 \mathrm{~N}$ & $7 E$ & .68 & .50 & $\cdots$ & ....... \\
\hline 116 & Rudolph.... & vilas...... & $43 \mathrm{~N}$ & $7 \mathrm{E}$ & .52 & .22 & $\cdots$ & ........ \\
\hline 120 & St. Croix.... & Donglas... & 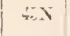 & $11 \mathrm{~W}$ & 4.00 & .55 & 19.7 & $1,030.4$ \\
\hline ..... & Sand $(1) \ldots \ldots \ldots$ & Burnett... & $88 \mathrm{~N}$ & $16 \mathrm{~W}$ & ..... & … & & \\
\hline 120 & Sand $(2) \ldots$. & Burnett... & $40 \mathrm{~N}$ & $15 \mathrm{~W}$ & 1.70 & 1.45 & 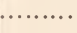 & ..... \\
\hline 120 & Sand (3)..... & Polk........ & $\sin$ & $18 \mathrm{~W}$ & 1.22 & .45 & .... & ...... \\
\hline 116 & Sand $^{4}(4) \ldots$. & Vilas........ & $42 N$ & $7 \mathrm{E}$ & 1.65 & .87 & 67.2 & 793.6 \\
\hline$\cdots \cdot$ & Sanford....... & Vilas..... & $43 \mathbf{N}$ & $6 \mathrm{E}$ & .77 & .40 & ...... & ........ \\
\hline 120 & Shell ......... & Washburn.. & $\begin{array}{l}37 \mathrm{~N} \\
3 \times \mathrm{N}\end{array}$ & $12 \mathrm{~W}$ & 3.25 & 2.50 & 49.2 & $3,200.0$ \\
\hline 120 & Silver (1) ............ & Barron...... & $26 \mathrm{~N}$ & $12 \mathrm{~W}$ & .... & ... & ..... & .......... \\
\hline 75 & Silver (2) $\ldots \ldots \ldots \ldots$ & Kenosha..... & IN & $20 \mathrm{E}$ & 1.25 & .87 & 42.6 & 582.0 \\
\hline 58 & Silver $(3) \ldots \ldots \ldots$ & Waukesha.... & iN & $17 \mathrm{E}$ & .97 & .56 & 44.0 & 231.9 \\
\hline & Sishebogema.......... & Vilas........ & ${ }_{40 N}^{39 N}$ & $5 \mathbf{E}$ & 2.50 & irr. & ..... & ........ \\
\hline 58 & Soft $\ldots \ldots \ldots \ldots$ & Waukesha... & $7 \mathrm{~N}$ & $17 \mathrm{E}$ & .32 & .20 & & \\
\hline & speese.......... & Oneida..... & $39 N$ & $5 \mathrm{E}$ & .32 & .31 & $\cdots$ & ....... \\
\hline 116 & Squirrel....... & Oneida. ..... & $39 \mathrm{~N}$ & $5 \mathbf{E}$ & 3.75 & 1.00 & 33.8 & $1,568.0$ \\
\hline 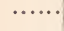 & South Crab ....... & Vilas.......... & $43 N$ & $6 E$ & .68 & .20 & .......... & ……... \\
\hline 120 & spirit......... & Burnett...... & $37 \mathrm{~N}$ & $18 W$ & 1.70 & 1.00 & 24.6 & 640.0 \\
\hline 116 & star.............. & Vilas......... & $41 \mathrm{~N}$ & $x \mathbf{E}$ & 2.12 & 1.60 & 26.2 & $1,152.0$ \\
\hline
\end{tabular}

4 Listed as White Sand Lake by Birge and Juday. 
"IABLE 2 (fentinued)

\begin{tabular}{|c|c|c|c|c|c|c|c|c|}
\hline $\begin{array}{c}\text { Page } \\
\text { map } \\
\text { ped }\end{array}$ & Lake & Counts & Town & Range & $\begin{array}{l}\text { Length } \\
\text { (Miles) }\end{array}$ & $\begin{array}{c}\text { Maxi- } \\
\text { mum } \\
\text { breadth } \\
\text { (Miles) }\end{array}$ & $\begin{array}{l}\text { Maxi- } \\
\text { mum } \\
\text { depth } \\
\text { (Feet) }\end{array}$ & $\begin{array}{l}\text { Area } \\
\text { (Acres) }\end{array}$ \\
\hline & Streitor..... & Vilas... & $4 . \mathrm{N}$ & $6 \mathbf{E}$ & .44 & .28 & & \\
\hline ... & Sunday ..... & Oneida..... & $39 \mathrm{~N}$ & $5 \mathbf{E}$ & .75 & .37 & & \\
\hline ... & Tamarack... & Vilas.... & $43 \mathrm{~N}$ & $5 \mathbf{E}$ & .56 & . 40 & & \\
\hline .... & Tank............ & vilas....... & $40 \mathrm{~N}$ & $6 \mathbf{E}$ & .24 & . & & $\cdots$ \\
\hline 104 & Taslor .......... & Waupeca... & $22 \mathrm{~N}$ & $11 \mathrm{E}$ & .45 & .31 & 55.7 & 51.2 \\
\hline 116 & Tenderfoot...... & Vilas........ & $42 \mathrm{~N}$ & $8 \mathbf{E}$ & 1.60 & 1.50 & 27.9 & 646.4 \\
\hline$\cdots$ & Tied Canoe ${ }^{5}$.. & & $\cdots$ & & & & & \\
\hline$\cdots$ & Travis....... & Polk...... & $33 \mathrm{~N}$ & $17 \mathrm{~W}$ & . & $\cdots$ & & . \\
\hline 116 & Trout............... & Vilas.... & ${ }_{41}^{41 \mathrm{~N}}$ & $6 \mathrm{E}$ & 4.50 & 2.40 & 115.0 & $4,160.0$ \\
\hline 116 & Turtle (North) .. & Vilas.... & $43 \mathrm{~N}$ & $5 \mathbf{E}$ & 1.25 & .80 & 47.6 & $640=0$ \\
\hline 116 & Turtle (South) .. & Vilas..... & $43 \mathrm{~N}$ & $5 \mathrm{E}$ & 2.25 & .63 & 43.0 & 793.6 \\
\hline 120 & Turtle (Lower)... & Barron.. & $34 \mathrm{~N}$ & $14 \mathrm{~W}$ & 1.50 & $.4 \pi$ & … & ..... \\
\hline 120 & Turtle (Upper)... & Barron.... & $34 \mathrm{~N}$ & $14 \mathrm{~W}$ & 2.30 & .40 & 23.0 & 480.0 \\
\hline 120 & Vermilion....... & Barron.... & $\sin$ & $13 \mathrm{~W}$ & 1.70 & 1.20 & ..... & ..... \\
\hline 120 & Wapagossett ${ }^{6} .$. & Polk....... & $33 \mathrm{~N}$ & $16 \mathrm{WV}$ & 3.50 & 1.20 & 27.9 & $1,452.8$ \\
\hline 24 & Waubesa....... & Dane.... & $6 \mathrm{~N}$ & $10 \mathrm{E}$ & 4.20 & 1.40 & 36.6 & $2,034.4$ \\
\hline …... & White Ash..... & Polk...... & $34 \mathrm{~N}$ & $16 \mathrm{~W}$ & 1.77 & .40 & $\cdots$ & ....... \\
\hline 120 & Whitefish...... & Sawyer... & $39 \mathrm{~N}$ & $9 \mathrm{~W}$ & 2.60 & 6.) & 73.8 & 896.0 \\
\hline 111 & White Sand..... & Vilas..... & $41 \mathrm{~N}$ & $5 \mathrm{E}$ & 2.75 & $i .00$ & & \\
\hline ...... & Whitney ......... & Vilas....... & $42 \mathrm{~N}$ & $6 \mathrm{E}$ & .56 & 45 & … & ... \\
\hline 116 & Wildeat.......... & Vilas.......... & $43 \mathrm{~N}$ & 䜣 & .87 & .60 & $\ldots \ldots \ldots$ & n...... \\
\hline 120 & Wild Goose ..... & Polk........ & $34 \mathrm{~N}$ & $17 \mathrm{~W}$ & .95 & .64 & 14.8 & 256.0 \\
\hline 92 & Winnebago....... & ........... & $15 \mathrm{~N}$ & $17 \mathrm{E}$ & 28.00 & 10.40 & 21.0 & $137,708.0$ \\
\hline 116 & Wolf................. & Vilas......... & $42 \mathrm{~N}$ & $7 \mathbf{E}$ & 1.21 & .84 & ...... & ......... \\
\hline 104 & Youngs......... & Waupaca..... & $21 \mathrm{~N}$ & $11 \mathrm{E}$ & .09 & .07 & 11.6 & 3.0 \\
\hline
\end{tabular}

scep Lost Canoe.

${ }^{6}$ Listed as Sucker Lake by Birge and Juday. 



\section{KEY TO THE GENERA BASED UPON THE VEGETATIVE CHARACTERS.}

1. ( 35 ) Coloring matter not restricted to definite plastids..........

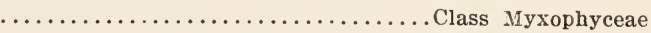

2 ( 22 ) Cells solitary or in colonies, never in filaments...........

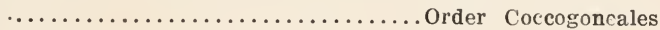

3. ( 12 ) Ceils solitary or in colonies that never contain more than a few cells.............................. 4

4. ( 7) Cells spherical or hemispherical ................. 5

5. (6) Cells without a definite arrangement.......... Chroococcus p. 27

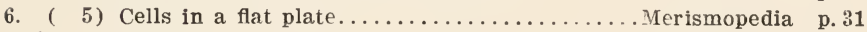

7. ( 4) Cells longer than they are broad..................... 8

8. ( 11 ) Individual cells not enclosed by a special gelatinous vesicle 9

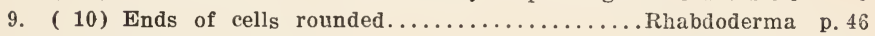

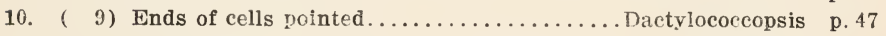

11. ( 8) Individual cells or groups of cells enclosed by a gelatinous

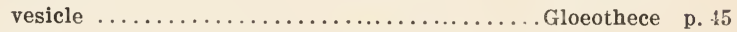

12. ( 3 ) Cells in colonies that contain many cells when mature.... 13

13. ( 18) Cellular arrangement within colony definite ........... 14

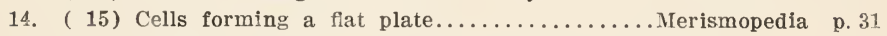

15. ( 14) Cells forming a hollow sphere one cell in thickness........ 16

16. ( 17 ) Center of colony with radiating gelatinous strands.........

17. (16) Center of colony without radiating gelatinous strands...... $\ldots \ldots \ldots \ldots \ldots \ldots \ldots \ldots \ldots \ldots \ldots$ Coelosphaerium p. 33

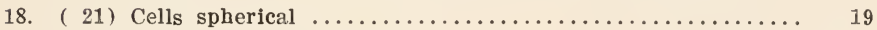

19. ( 20) Cells densely aggregated.................................... 38

20. (19) Cells some distance from one another.........Aphanocapsa p. 41

21. ( 18) Cells longer than they are broad.............Aphanothece p. 43

22. ( 2) Cells in simple or branched filaments..Order Hormogoneales 23

23. ( 30 ) Trichomes without heterocysts.......Family Oscillatoriaceae 24

24. ( 29) Trichomes solitary or in flocculent readily dissociating

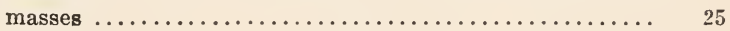

25. ( 26 ) Trichomes containing but one spirally twisted cell.......... $\ldots \ldots \ldots \ldots \ldots \ldots \ldots \ldots \ldots \ldots \ldots \ldots \ldots$ spirulina

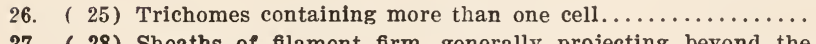

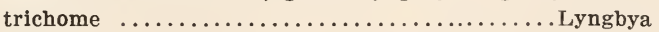

28. ( 27) Sheath delicate or lacking, not projecting beyond the trichome ......................... Oscillatoria

29. (24) Trichomes laterally united to form free-floating bundles which do not dissociate readily.......... Trichodesmium

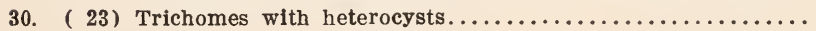


31. ( 34 ) Trichomes not attenuated..............Family Nostocaceae

82. ( 33 ) Filaments solitary or interwoven to form flocculent masses

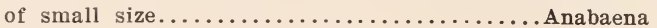

33. ( 32 ) Filaments laterally joined to form small plate-like colonies of macroscopic size.................. Aphanizomenon

34. ( 31 ) Trichomes attenuated to a hair-like point.......Gloeotrichia

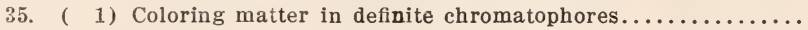

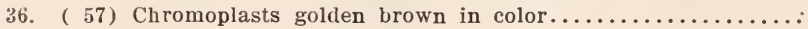

p. 61

p. 63

37. ( 38 ) Wall heavily impregnated with silica and definitely marked with grooves or rows of dots........Bacillarieae (see part 2).

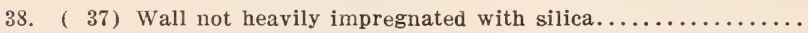

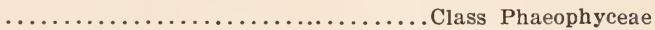

39. ( 52) Cells generally motile, rarely forming palmella or rhizopodial stages.............. Division Euchrysomonadinae

40. ( 45) Cells with one flagellum.............. Order Chromulinales

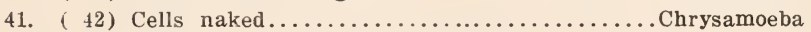

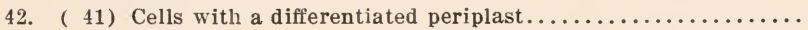

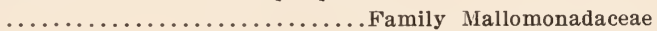

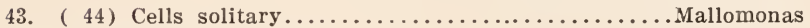

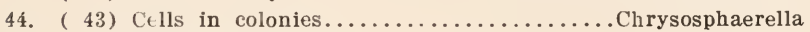

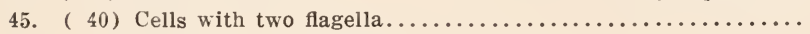

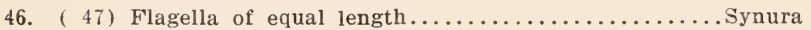

47. ( 46) Flagella of unequal length........... Order Ochromonadales

48. ( 51 ) Cells in a definite receptacle..........Family Dinobryaceae

49. ( 50 ) Receptacles homogeneous, without growth rings..Dinobryon

50. (49) Receptacles with successive growth rings....... Hyalobryon

51. ( 48 ) Cells never in a definite receptacle.......... Uroglenopsis

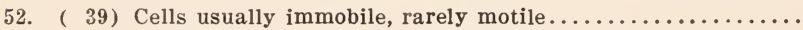

53. ( 54 ) Cells spherical to ovoid, embedded in a gelatinous mass.... Phaeococcus

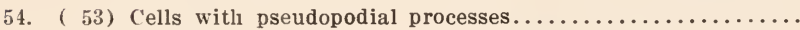

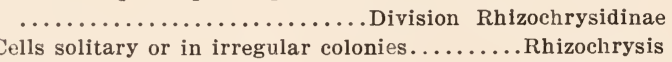

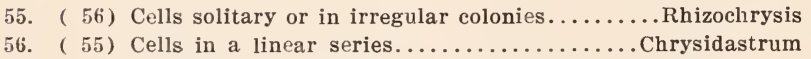

57. ( 36 ) Chromoplast grass-green or yellowish-green in color........

58. ( 69 ) Chromoplast yellowish-green, with oil not starch the assimi-

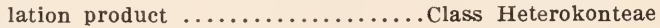

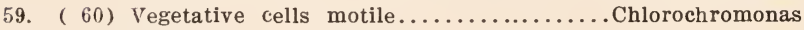

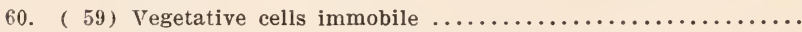

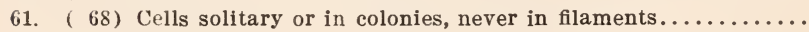

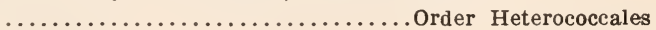

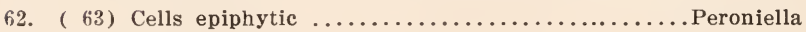

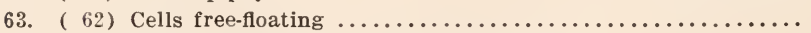

64. ( 65 ) Length of cells several times the diameter..... Ophiocytium

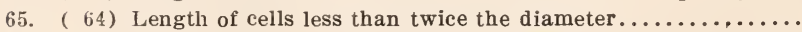

66. ( (i7) Cells irregularly distributed throughout an ovoid, gelatinous

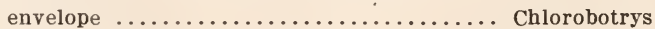

67. ( 66) Cells arranged about a common center and enclosed by an

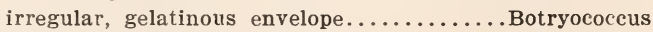

68. ( 61 ) Cells united to form simple filaments........... Tribonema

69. ( 58 ) Chloroplast grass-green, generally with pyrenoids and starch .Class Chlorophyceae

p. 77

p. 78

58

59

p. 80 
70. ( 71) Cells solitary or in families, divided into two symmetrical halves with a chloroplast in each half. Median region generally constricted..Family Desmidiaceae (See Part 2)

71. ( 70 ) Cells not divided into two symmetrical halves and without

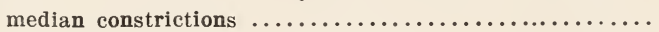

72. ( 85) Cilia normally present in vegetative cells. . Order Volvocales

73. ( 84 ) Anterior end of cells with two cilia $\ldots \ldots \ldots \ldots \ldots \ldots \ldots \ldots$

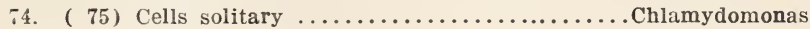

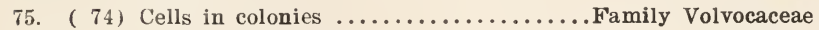

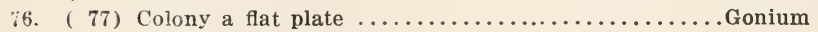

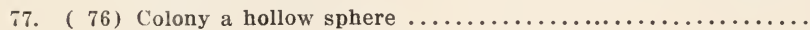

p. 94

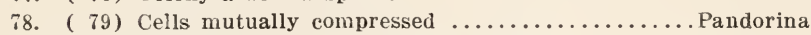

p. 95

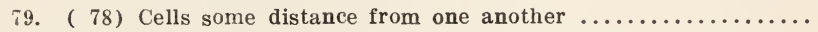

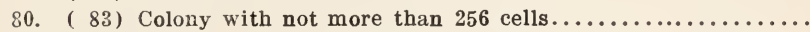

81. ( 82 ) Asexual reproduction by division of all cells to form daugh-

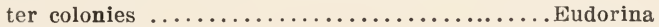

82. ( 81 ) Asexual reproduction by division of certain cells to form

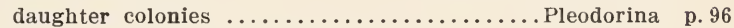

83. ( 80 ) Colony generally containing many cells............ Volvox

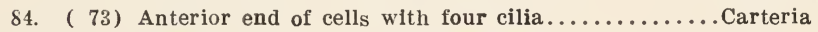

p. 92

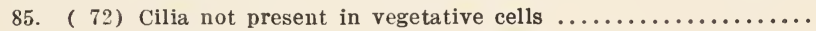

86. (183) Cells solitary or in colonies, never in simple or branched filaments ....................... Order Protococcales

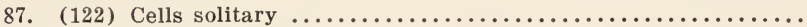

88. (121) Cells free-floating ............................... 89

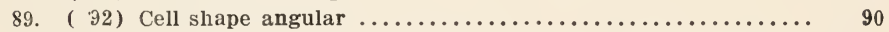

90. ( 91 ) Angles simple or with spines, never with long setae........

31. ( 90 ) Angles with tufts of long setae............. Polyedriopsis p. 124

92. ( 89 ) Cells spherical, ovoid, or elongate $\ldots \ldots \ldots \ldots \ldots \ldots \ldots \ldots . . .63$

93. (116) Length of cells not more than three times the diameter.... 94

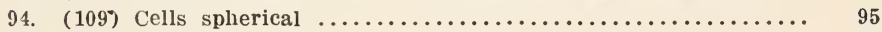

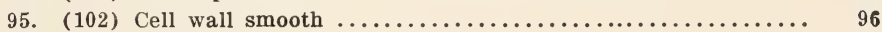

96. ( 99 ) Cells embedded in a gelatinous sheath............. 97

97. (98) Gelatinous sheath lamellated.....................eocystis p. 100

98. ( 97) Gelatinous sheath not lamellated........... Planktosphaeria p. 103

99. ( 96) Cells not embedded in a gelatinous sheath ............ 100

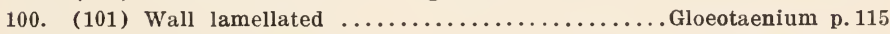

101. (100) Wall not lamellated ............................... 103

102. ( 95) Wall sculptured, denticulate, or with long spines or setae.. 103

103. (108) Setae or long spines covering the wall .............. 104

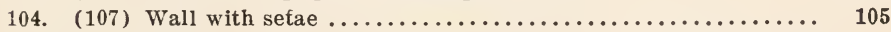

105. (106) Setae the same thickness throughout, or gradually tapering $\ldots \ldots \ldots \ldots \ldots \ldots \ldots \ldots \ldots \ldots \ldots \ldots$ Golenkinia p. 127

106. (105) Setae visibly thickened in the lower third...Acanthosphaeria p. 128

107. (104) Walls with long spines............................... 128

108. (103) Denticulations or ridges covering the walls......Trochiscia 108

109. ( 94) Cells ovoid to reniform ....................... 110

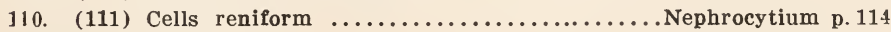

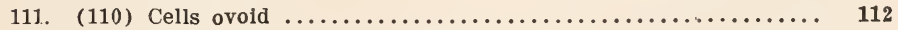

112. (113) Walls without setae or spines....................... 110

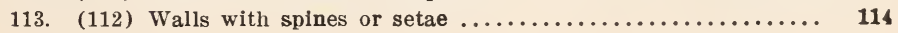




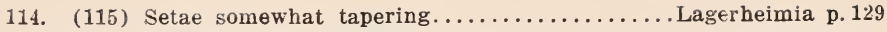

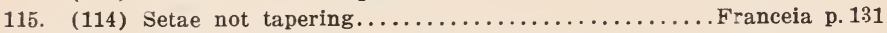

116. ( 93 ) Length of cells several times the diameter........... 117

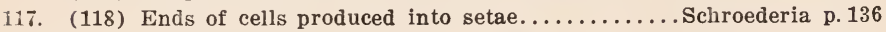

1i8. (11i) Ends of cells not produced into setae .............. 119

119. (120) Chloroplast with an axial row of pyrenoids....Closteriopsis p. 136

120. (119) Chloroplast without or with one pyrenoid..Ankistrodesmus p. 134

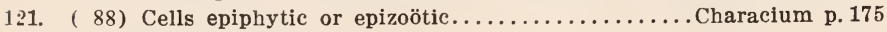

122. ( 87$)$ Cells in colonies .............................. 123

123. (142) Colonies enclosed by a conspicuous gelatinous sheath..... 124

124. (125) Cells connected by branching remains of old cell walls...... ............................... Dictyosphaerium p. 104

125. (124) Cells not connected by branching remains of old cell walls.. 126

126. (137) Cells spherical to ovoid or reniform $\ldots \ldots \ldots \ldots \ldots \ldots \ldots \ldots 127$

127. (136) Chloroplast cup to disc-shaped and parietal............ 128

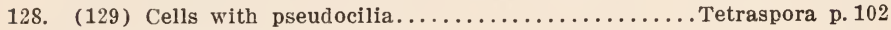

129. (128) Cells without pseudocilia...................... 130

130. (131) Colonies never containing more than eight cells. Gloeocystis p. 100

151. (130) Colonies always with at least eight cells............. 132

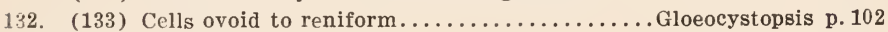

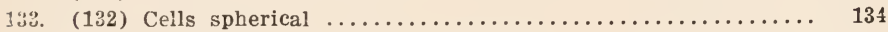

134. (135) Chloroplasts of old cells cup-shaped...........Sphaerocystis p. 101

135. (134) Chloroplasts of old cells disciform.........Planktosphaeria p. 103

136. (127) Chloroplasts star-shaped and central..........Asterococcus p. 103

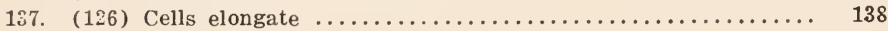

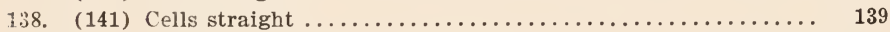

139. (140) Colonies with cells in groups of two............ Elaktothrix p. 139

140. (139) Colonies with cells in groups of $2-4-8 \ldots \ldots \ldots$ Quadrigula p. 137

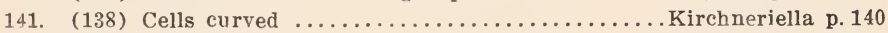

142. (123) Cells not enclosed by a gelatinous sheath............ 143

113. (156) Colonies always forming a flat plate ............... 144

144. (3.55) Number of cells, except in rare cases, greater than two.... 145

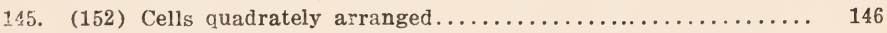

146. (147) Quadrate arrangement apparent in end view of colony......

147. (146) Quadrate arrangement apparent in front view of colony.... 148

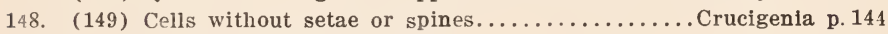

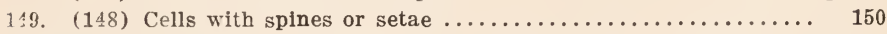

150. (151) Long setae or spines on outer face of cells.... Micractinium p. 125

151. (150) Short spines on outer face of cells............. Tetrastrum p. 149

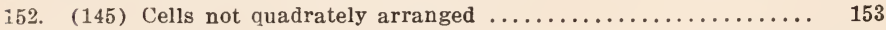

153. (154) Colony a flat circular or oval disc..............Pediastrum p. 166

154. (153) Colony a single or double row of cells.......... Scenedesmus p. 150

155. (144) Number of cells in colony always two..........Euastropsis p. 174

156. (143) Colony not forming a flat plate ................. 157

157. (166) Colony enclosed by old cell wall .................. 158

158. (165) Wall enclosing colony greatly expanded and homogeneous.. 159

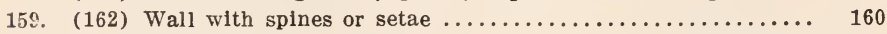

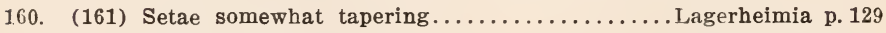

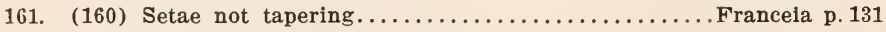

162. (159) Wall without spines or setae.................. 163

163. (164) Cells ovoid ........................................... 110 


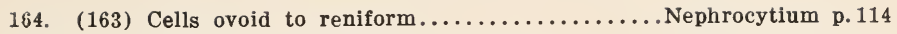

165. (158) Wall lamellated but not expanded.............oeotaenium p. 115

166. (157) Colony not enclosed by old cell wall............... 167

167. (176) Length of cell not more than twice the breadth......... 168

168. (171) Remains of old cell walls at center of and holding colony

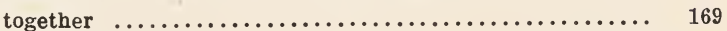

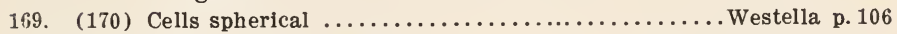

170. (169) Cells ovoid to reniform................ Dimorphococcus p. 106

171. (168) Colonies without remains of old cell wall at center....... 172

172. (173) Outer face of cells with long setae............Micractinium p. 125

173. (172) Outer face of cells with short spines or without ornamenta-

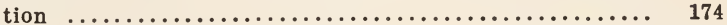

174. (175) Cells without spines on outer face............... 160

175. (174) Cells with short spines on outer face........... Sorastrum p. 162

176. (167) Length of cells several times the breadth............ 177

177. (178) Colony forming a closed hollow sac..........Hydrodictyon p. 165

178. (177) Colony not forming a closed hollow sac.............. 179

179. (180) Cells radiating from a common center..........Actinastrum p. 164

180. (179) Cells not radiating from a common center............. 181

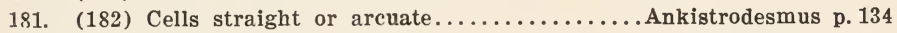

182. (181) Cells markedly curved......................................... 132

183. ( 86 ) Cells in simple or branched filaments............... 184

184. (195) Cells with one to eight chloroplasts, chloroplasts never re-

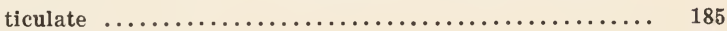

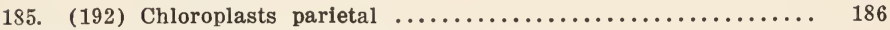

186. (191) Chloroplasts laminate to disciform................. 187

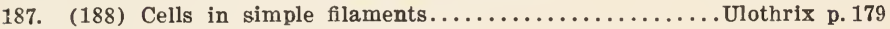

188. (187) Cells in branching filaments.................... 189

189. (190) Setae confined to terminal cells or lacking... Stigeoclonium p. 180

190. (189) Setae occurring on any cell of filament....... Aphanochaete p. 181

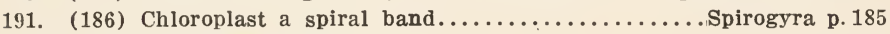

192. (185) Chloroplast central ......................... 193

193. (194) Chloroplast an axial plate................................ 184

194. (193) Chloroplasts stellate ..................................... 184

195. (184) Chloroplasts numerous or united to form a single reticulate mass .......................... Cladophora p. 182 


\section{Class MYXOPHYCEAE.}

Cells solitary, in colonies of definite or indefinite shape, or in filaments but always surrounded by a gelatinous to tough envelope which is generally hyaline but may be colored. Plants living a free-floating, sessile, epiphytic or endophytic existence. Cell shape various; spherical, hemispherical, ovoid, bacilliform, disciform or angular. Cells with the coloring matter localized at the periphery but not in definite, visible chromatophores. Color of cells typically blue-green but at times grey, yellowish, reddish, brownish or nearly grass-green. The color variation being due to different amounts of the three component pigments, carotin, chlorophyll, and phycocyan; the latter being found only in this class of plants. Cells containing a single nucleus of a primitive type (the central body) that contains linin and chromatin but is without a membrane or nucleole.

Reproduction always asexual, either by vegetative division of cells; fragmentation of the filaments into smaller portions (hormogones) which may move a short distance by spontaneous movement and then come to rest; or by special non-motile reproductive bodies (gonidia and resting spores).

KEY TO THE ORDERS.

Cells solitary or in colonies, never in filaments............ Coccogonrades Cells in simple or branched filaments.................. Hormogoneares

\section{Order COCCOGONEALES.}

Cells rarely solitary, generally in colonies of regular or irregular shape, and with the cells definitely or indefinitely arranged within a eopious gelatinous envelope. Colonies living a free-floating, sessile, epiphytic or endophytic existence. Cells differentiated into a basal and distal portion or without such differentiation. Cell shape various; spherical, ovoid, cylindrical, acicular, or angular.

Asexual reproduction by vegetative division of the cells or, in rare cases, by a division of the cell contents into non-motile gonidia. Resting cells and sexual reproduction unknown.

There are two families in the order only one of which, the Chroococcaceae, is found in the plankton. 


\section{Family CHROOCOCCACEAE.}

Cells not differentiated into an apical and basal portion; rarely solitary, generally in colonies of definite or indefinite shape and always enclosed by a gelatinous sheath. Cell shape various, and cellular arrangement within the colonial envelope definite or indefinite.

Asexual reproduction by vegetative cell division and the fragmentation of the colonies. Gonidia formation occasionally taking place in certain genera.

\section{KEY TO THE GENERA.}

Cells solitary or in colonies that never contain more than a few cells.

Cells spherical or hemispherical................... Своососсus

Cells longer than they are broad.

Individual cells or groups of cells enclosed by a gelatinous

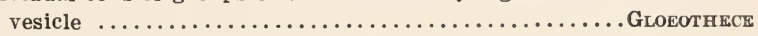

Individual cells or groups of cells without vesicles.

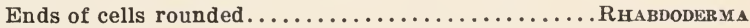

Ends of cells pointed................... DActrLococcopsis

Cells always in colonies that contain many cells when mature.

Cellular arrangement within colony definite.

Cells forming a flat plate..........................

Cells forming a hollow sphere one cell in thickness.

Center of colony with radiating gelatinous strands. GoMPHOSPHANRIA

Center of colony without radiating strands...... COELOSPHAFrTUM Cellular arrangement within colony indefinite.

Cells spherical.

Cells densely aggregated $\ldots \ldots \ldots \ldots \ldots \ldots \ldots \ldots$ Mrcrocxstis

Cells some distance from one another.............. ApHanocapsa

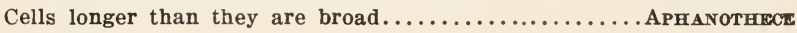

\section{CHROOCOCCUS Nägeli 1849.}

Cells spherical, usually hemispherical for some time after division; sulitary or 2-4-8-16 or more united in colonies enclosed by a hyaline or colored, homogeneous or lamellated sheath; free-floating, sessile, or epiphytic. Individual cells of colony at times surrounded by a homogeneous or lamellated sheath. Cell contents grey, grey-green, bluegreen, olive-green, yellowish, orange, reddish or violet in color; homogeneous or granular.

Reproduction by vegetative division of cells in three directions.

\section{KEY TO THE SPECIES.}

Sheaths enclosing cells homogeneous.

Cells solitary, in twos, and in fours

.C. Mrnutus

Cells in colonies of $4-8-16$ or more.

Individual cells or groups of cells some distance from one

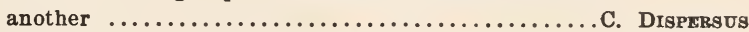

Individual cells or groups of cells fairly close together..C. LIMNEricus 
Sheaths enclosing cells distinctly lamellated.

Diameter of cell and sheath not exceeding $40 \mu \ldots \ldots \ldots \ldots \ldots$. Turgidus

Diameter of cell and sheath over $60 \mu \ldots \ldots \ldots \ldots \ldots \ldots \ldots$. Giganteus

\section{Chroococcus Minutus (Kützing) Nägeli. Pl. 1, Fig. 1.}

Gatt. einz. Algen 46. 1849.

Protococcus minutus Kützing, Tabulae Phycol. 1: pl. 5.

Cells spherical or hemispherical, solitary or in colonies of 2-4 enclosed by a wide, spherical, homogeneous, gelatinous sheath. Cell contents pale blue-green to grey, homogeneous or granulose. (Tychoplanktont).

Diam. cells (without sheath) $5-7 \mu$, (with sheath) $6-12 \mu$; length (without sheath) $5-10 \mu$, (with sheath) $5-13 \mu$.

Wolf (rrr).*

Chroococcus dispersus (v. Keissler) Lemmermann. Pl. 1, Fig. 2. Arkiv. f. Botanik 2, No. 2: 102. 1904.

Chroococcus minor var. dispersus v. Keissler, Verh. d. zool.-bot. Ges. Wien 52: 311, fig. 6. 1902.

Cells spherical, 4-16 or more united to form spherical, ovoid, or irregular colonies. Individual cells some distance from one another, or in compact groups that lie some distance from one another within the colony. Individual cell sheaths frequently confluent with the colonial sheath. Cell contents homogeneous, pale to bright blue-green. (Euplanktont).

Diam. cells (without sheath) $3-4 \mu$; (with sheath) $6 \mu$. Distance between cells or groups of cells 15-20 $\mu$.

Browns (rr), Pokegama (1) (rr).

A species that is closely related to $C$. limneticus but one where the number of cells in the colony is usually greater, and where the individual cells or groups of cells are some distance from one another.

\section{var. minor var. nov. Pl. 1, Fig. 3.}

Cells smaller than the typical form and with pale grey contents. (Euplanktont).

Diam. cells 1. 75-2. $5 \mu$.

Long (3) (rrr), Middle McKenzie (rr), Palmer (rr).

The relative abundance of the individual species is shown by the following symbols; (aaa) very abundant, (aa) abundant, (a) fairly abundant, (ccc) very common, (cc) common, (c) fairly common, (s) fairly scarce, (ss) scarce, (sss) very scarce, (r) fairly rare, (rr) rare, (rrr) very rare. 


\section{Chroococcus Limneticus Lemmermann. Pl. 1, Fig. 4.}

Bot. Cent. 76: 153. 1898; Forschungsbr. a. d. Biol. Stat. zu Plön 7: 132, pl. 1, figs. 22-23. 1899.

Mature cells spherical to subspherical, 4-32 in a free-floating spherical to ovoid colony. Cells fairly close together and equidistant from one another within the colony, sometimes in groups of $2-4$ but with the groups lying close together. Cell division in all three planes but a majority of the cells dividing in the same plane and giving the colony a somewhat tabular appearance. Many hemispherical cells present because of the slow maturation after division. Individual cell sheaths homogeneous and frequently confluent with colonial envelope. Cell contents homogeneous; grey, pale to bright blue-green, or olive-green. (Euplanktont).

Diam. cells (without sheath) 6-12 $\mu$, (with sheath) 8-14 $\mu$.

Balsam (r), Bear (1) (rr), Bear (2) (rrr), Bear Trap (sss), Beasley (rr), Beaver (1) (r), Beaver (2) (ss), Big Butternut (r), Birch (1) (rr), Birch (2) (ss), Birch Island (s), Blake (sss), Bloom (s), Boulder (rrr), Browns (s), Camp (rr), Catfish (rr), Chetac (r), Chetek (rrr), Cranberry (sss), Dunham (rr), Dutchmans (r), Eagle (rr), East (rr), Fish (rr), Found (rr), Fowler (rr), Grassy (rr), Grindstone (rr), Half Moon (rr), Horseshoe (1) (r), Island (rr), Kawaguesaga (rr), Kimball (rr), Lac Court Oreilles (rr), Lac la Belle ( $r$ ), Little Bass (2) (ss), Little Butternut (rr), Little Rice (2) (rr), Little Wood (sss), Loveless (r), Mary (rr), Middle McKenzie (r), Mill (rr), Mud (1) (rr), Mud (2) (rr), Mudhen (r), Nicaboyne (r), North Twin (rr), Oconomowoc (rr), Old Taylors (rr), Pewaukee (rr), Pike (rr), Pine Tree (rr), Pokegama (1) (r), Pokegama (2) (rrr), Pokegama (3) (rr), Poor Farm (rr), Poplar (ss), Reserve (sss), Rice (1) (r), Round (3) (rr), Sand (1) (s), Sand (3) (sss), Sand (4) (rr), Shell (sss), Silver (2) (r), Spirit (r), Squirrel (r), Tenderfoot (rrr), Travis (rrr), Upper Nashotah (rr), Upper Nemahbin (rr), White Ash (ss), Whitefish (s), Wildcat (rr), Winnebago (r), Wolf (rr).

This is preëminently a plankton species. It is widely distributed throughout the state and may be the dominant member of the Myxophyceae in lakes with very soft water, but it never occurs in sufficient abundance to eause the familiar phenomenon of blooming. The cells are quite variable in both color and size.

\section{var. subsalsus Lemmermann. Pl. 1, Fig. 5.}

Forschungsbr. a. d. Biol. Stat. zu Plön 8: 84. 1901; Arkiv f. Botanik 2: No. 2: 101, pl. 1, fig. 9. 1904 .

Cells spherical to subspherical, 8-16-32 in a somewhat spherical or broadly ellipsoidal colony with a wide gelatinous envelope. Cell contents homogeneous; pale to bright blue-green. (Euplanktont). 
Diam. cells (without sheath) $3.5-4.5 \mu$; (with sheath) $4.5-5.5 \mu$.

Big Bass (sss), Blake (rr), Lac Court Oreilles (ss), Owen (ss), Paddock ( $r$ ).

The chief distinction of this and the following varieties is in the size of the cells.

var. CARneus (Chodat) Lemmermann. Pl. 1, Fig. 6. Arkiv för Botanik 2, No. 2: 101.1904.

Cells spherical to hemispherical, 4-8-16 irregularly distributed throughout a spherical to ovoid gelatinous matrix. Individual sheaths of cells confluent with the colonial envelope. Cell contents homogeneous; color variable, ochraceous, grey, blue-green or olive green. (Euplanktont).

Diam. cells (without sheath) 7-9 $\mu$.

Big Bass (ss), Harris (r), Mendota (rr), Nancy (r), Oconomowoc (rr).

var. Distans G. M. Smith. Pl. 1, Fig. 7.

Bull. Torr. Bot. Cl. 43: 481, pl. 26, fig. 26. 1916.

Cells spherical to hemispherical, 8-32 in a colony and lying some distance from one another within a spherical to ovoid, hyaline, homogeneous, gelatinous, colonial envelope. Individual cell sheaths confluent with the colonial envelope. Cell contents homogeneous, grey to pale blue-green in color. (Euplanktont).

Diam. cells (without sheath) 6.5-7 $\mu$.

Bear Trap (s), Birch Island (rr), Browns (sss), Cochrane (r), Cranberry (sss), Lindy (rr), Muskallonge (rr).

var. Elegans G. M. Smith. Pl. 1, Fig. 8.

Trans. Wis. Acad. Sci., Arts, \& Lett. 19 ${ }^{1}$ : 619. 1918.

Cells circular to semicircular in front view, somewhat flattened in side view. Colonies enclosed by a spherical, lomogeneous, hyaline, gelatinous envelope. Individual sheaths of cells conspicuous. Cell contents homogeneous; generally bright blue-green in color. (Euplanktont).

Diam. cells (without sheath) 18-22 $\mu$; (with sheath) $20-26 \mu$.

Delavan (rr).

Chroococcus giganteus W. West. Pl. 2, Fig. 1.

Jour. Roy. Micr. Soc. 1892: 741, pl. 10, figs. 59-60. 1892.

Cells ordinarily hemispherical, rarely becoming spherical or ovoid after division. Solitary or in colonies of two (rarely 3-4) enclosed by 
a thick, hyaline, markedly lamellate, gelatinous envelope. Envelope of individual cells conspicuous, lamellated. Cell contents distinctly granulose, bright blue-green. (Tychoplanktont).

Diam. cells (without sheath) $54-58 \mu$; (with sheath) $67-70 \mu$.

Mary (rrr).

\section{Chroococcus turgidus (Kützing) Nägeli. Pl. 1, Fig. 9.}

Gatt. einz. Algen 46. 1849; G. S. West, Brit. Freshw. Algae 352, fig. 166 ${ }_{\mathrm{B}} \cdot 1904$.

Cells hemispherical, spherical, ovoid, or somewhat flattened by mutual compression. Cells solitary or in colonies of $2-4$ (rarely 8 ) enclosed by a thick, hyaline, generally lamellated, gelatinous sheath. Individual cells also with hyaline, lamellated sheaths. Cell contents homogeneous or finely granulose; pale to bright blue-green or rarely brownish in color. (Tychoplanktont).

Diam. cells (without sheath) $8-32 \mu$; (with sheath) $13-40 \mu$.

Beasley (rrr), Beaver (2) (rr), Browns (rr), Hillman (rr), Horse (rrr), Oconomowoc (rr), Otter (rr), Rudolph (rr), Sand (2) (rr), Upper Turtle (rr), Waubesa (rrr).

\section{MERISMOPEDIA Meyen 1839.}

Colonies always forming flat, curved, or irregularly twisted plates one cell in thickness with the constituent cells in rectilinear series and usually in groups of four. Cells spherical to subspherical with rounded ends, hemispherical for some time after division. Individual sheaths of cells rarely distinct, generally confluent with the copious, hyaline, homogeneous, colonial envelope. Number of cells in colony 4-4000, cell number a multiple of two in young colonies, not a multiple of two in old colonies. Cell contents generally homogeneous, rarely with pseudovacuoles. Color varying from grey through light to bright bluegreen, rarely rose pink to violet.

KEY TO THE SPECIES.

Cells bright blue-green .M. Eitegans

Cells pale blue-green.

Cells some distance from one another..........

.M. Punctata

Cells close together (not mutually compressed).

Diameter of cells $1.5-2 \mu \ldots \ldots \ldots \ldots \ldots \ldots \ldots \ldots \ldots \ldots \ldots \ldots \ldots$ TENUissima

Diameter of cells $3-6 \mu \ldots \ldots \ldots \ldots \ldots \ldots \ldots \ldots \ldots \ldots \ldots \ldots \ldots \ldots \ldots \ldots$ GLAUCA 
Merismopedia elegans A. Braun. Pl. 2, Fig. 5.

in Kützing, Species algarum 472. 1849; G. S. West, Brit. Freshw. Algae 348: fig. $1622_{\mathrm{C}} \cdot 1904$.

Colonies small or large, of $16-4000$ cells regularly arranged in rectilinear series and groups of four; with the cell number a multiple of two in young colonies but becoming irregular in arrangement and number in old colonies. Colonies flat except when containing many cells. Cells spherical to broadly ovoid, with homogeneous, bright blue-green contents. (Facultative Planktont).

Cells 5-7 $\mu$ broad, 5-9 $\mu$ long.

Carson (rr), Center (rr), Green (1) (rr), Kegonsa (rr), Little Bear (rrr), Mendota (r), Monona (r), Mud (1) (rr), Nancy (r), Upper Nashotah (rrr), Waubesa (rr).

This alga is a good example of a typical benthitic organism that is able to thrive under limnetic conditions. It never becomes a conspicuous member of the plankton but the colonies attain a much larger size and I have observed specimens 60-70 cells broad and 60-90 cells long. 'I'here is a certain amount of irregularity in such colonies so exact determinations of cell numbers are impossible.

var. major var. nov. Pl. 2, Fig. 6.

Colonies usually containing many cells. Cell shape the same as in the typical form. Cell contents homogeneous, bright blue-green. (Euplanktont).

Cells 10-11 $\mu$ broad, 12-14 $\mu$ long.

Beaverdam ( $r$ ), Lindy ( $r r)$.

Merismopedia glauca (Ehrenberg) Nägeli. Pl. 2, Fig. 4.

Gatt. einz. Algen 55, pl. 1, fig. $\mathrm{D}^{1} .1849$.

Colonies generally containing less than 64 cells, compactly and regularly arranged. Cells spherical to broadly ellipsoid, hemispherical for some time after division. Cell contents homogeneous, generally pale blue-green. (Facultative Planktont).

Diam. cells $3-5 \mu$.

George (rr), Jones (rrr), Lac Court Oreilles (rrr), Loon (rrr), Meta (rr), Mill (rr), Waubesa ( $r r)$.

This species resembles $M$. punctata in the size of the cells but differs in the distance between the cells. 


\section{Merismopedia punctata Meyen. Pl. 2, Fig. 3.}

Arch. f. Naturgesch. 5²: 67. 1839; Kützing, Tabulae Phycol. 5: 13, pl. 38, fig. 3. 1855.

Colonies small, with the cells some distance from one another but regularly arranged in rectilinear series. Cells spherical to broadly ovoid or hemispherical. Cell contents homogeneous, grey to pale bluegreen: (Tychoplanktont).

Diam. cells 2.5-3.5 $\mu$.

Big Bass (rrr).

Merismopedia tenuissima Lemmermann. Pl. 2, Fig. 2.

Bot. Cent. 76: 154. 1898; Forschungsbr. a. d. Biol. Stat. zu Plön 7: 132, pl. 1, fig. 21.1899.

Colonies rectangular, free-floating, generally with 16-100 cells lying close together. Rectilinear arrangement of cells soon breaking down and not evident when there are more than 32 cells in a colony. Colonies distorted when of any size. Cells spherical to ovoid, hemispherical for some time after division. Individual sheath of cells distinct or confluent with colonial envelope. Cell contents homogeneous; grey tc pale blue-green. (Facultative Planktont).

Diam. cells (without sheath) $1.5-2 \mu$.

Camp (rr), Little Doctor (rr), Long (3) (r), Mary (rr).

The irregular cellular arrangement is very common in older colonies and is not due to the size of the colony, since the species is one of the smallest of the genus, but to irregularities in cell division.

\section{COELOSPHAERIUM Nägeli 1849.}

Colonies microscopic, free-floating; spherical, ellipsoid, reniform, or irregular; enclosed by a delicate, hyaline, homogeneous or radially fibrillar, gelatinous envelope. Cells spherical, ovoid, ellipsoid, sub-pyriform and arranged in a single layer to form a hollow sac just beneath the periphery of the colonial envelope. Cell contents homogeneous and grey to bright blue-green; or reddish and containing numerous pseudovacuoles.*

Reproduction by vegetative cell division in three directions.

\footnotetext{
*These structures, which are also called gas vacuoles, are found in certain plankton species of the Myxophyceae. They are minute bodies, which are recidish through their refractive power, that occur in large numbers in all cells of the colony. Various functions have been ascribed to them, the most probable being a means of protection against too intense light, or a giving of greater buoyancy to the colony.
} 
KEY TO THE SPECIES.

Cells spherical.

Diameter of cells not exceeding $4 \mu \ldots \ldots \ldots \ldots \ldots \ldots \ldots \ldots \ldots$. KuEtzingIaUM

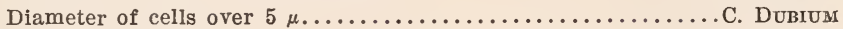
Cells ovoid to ellipsoid........................... Nafgelianua

\section{Coelosphaerium Kuetzingianum Nägeli. Pl. 3, Figs. 4-5.}

Gatt. einz. Algen 54, pl. 1, fig. C. 1849.

Colonies spherical to subspherical, enclosed by a very hyaline, homogeneous, gelatinous envelope. Cells spherical to subspherical, forming a single layer, with the individual cells or pairs of cells some distance from one another or close together. Cell contents homogeneous, without pseudovacuoles; usually grey to pale blue-green, rarely bright bluegreen. (Facultative planktont).

Diam. cells 2.25-4 $\mu$; diam. colonies $20-90 \mu$.

Balsam (rr), Bass (2) (rr), Bear (3) (r), Bear Trap (rrr), Beaverdam (ss), Big (ss), Big Butternut (sss), Birch Island (rrr), Blake (ss), Bone (rr), Browns (rr), Carson (r), Catfish (r), Clam (ss), Cochrane (sss), Crab (rr), Cranberry (ss), Crawling Stone (sss), Deer (rr), Diamond (rrr), Elizabeth (s), Eagle (ss), Fence (sss), Fish (rr), Grindstone (rr), Green (2) (rr), Half Moon (r), High (sss), Hillman (ss), Horseshoe (1) (rrr), Kegonsa (s), Kitten (rr), Island (ss), Lac la Belle (rr), Lindy (rr), Little Bear (rrr), Little Butternut (r), Little Crooked (rr), Little Rice (1) (ss), Little Wood (s), Long (2) (rr), Long (3) (rr), Loveless (sss), Mary (s), Mendota (s), Mercer (rrr), Mill (rrr), Mud (1) (cc), Mud (2) (r), Mudhen (s), Nancy (rrr), Nicaboyne (rr), North Turtle (ss), Oconomowoc ( $r$ ), Owen (rrr), Paddock (ss), Palmer (ss), Pardee (cc), Pewaukee (rr), Pine (2) (rr), Pine Tree (rr), Pokegama (1) (sss), Pokegama (2) (r), Pokegama (3) (rrr), Poplar (ss), Reserve (ss), Rice (1) (rr), Rock (sss), Round (3) (sss), Sand (1) (rr), Sand (3) (rr), Sand (4) (r), Silver (1) (ccc), Silver (2) (ss), South Turtle (s⿱宀) ), Spirit (ss), Sunday (r), Tamarack (rr), Tenderfoot (sss), Tied Canoe (rrr), Upper Nemahbin (rrr), Upper Turtle (sss), White Ash (sss), Whitefish (s), White Sand (sss), Wildcat (rr), Wild Goose ( $r r)$, Winnebago (rr), Wolf $(r)$.

The gelatinous sheath is generally so delicate that it is necessary to use Errera's method of mounting colonies in dilute India ink to demonstrate its presence. The specific limits of this species as established by different authors frequently includes $C$. Naegelianum as a synonym. C. Kuetzingianum and C. Naegelianum are two well defined species that differ in colony shape, cell shape, occurrence of pseudovacuoles, structure of colonial envelope, and relative abundance. C. Kuetzingianum is a species that is widely distributed throughout the state but one which rarely becomes a dominant member of the plankton and never occurs in sufficient abundance to cause blooming. 


\section{Coelosphaerium dubium Grunow. Pl. 3, Fig. 7.}

in Rabenhorst, Flora Eur. Algarum 2: 55. 1865; Schmula, Beibl. z. Hedwigla 5ร: : (47), figs. 1-2. 1898.

Colonies spherical to irregular, with three or four smaller colonies frequently enclosed by a common gelatinous envelope. Colonial envelope firm, hyaline, and homogeneous. Cells in a single layer and very close together at the periphery of the colonial envelope. Cell contents homogeneous or with pseudovacuoles; blue-green in color. (Facultative Planktont).

Cells 5-7 $\mu$ in diameter. Single colonies up to $150 \mu$ in diam; compound colonies up to $300 \mu$.

Mud (3) (rr).

Coelosphaerium Naegelianum Unger. Pl. 3, Fig. 6; Pl. 4, Fig. 1.

Denkschr. d. kais. Ak. d. Wiss. Wien 7: 196. 1854; Leitgeb, Mitt. d. naturw. Ver. Steiermark 2, Heft 1: 72, pl. 2, figs. 1-6. 1869; Borge, Bot. Not. 1900: 1.0, pl. 1, figs. $5^{\mathrm{a}-5^{\mathrm{b}}}$. 1900 .

Gomphosphaeria Naegeliana (Unger) Lemmermann. Kryptogamenfl. d. Mark Brandenburg 3, Algen 1: 80, 44, fig. 19. 1907; Bachmann, Arch. f. Hydrobiol. u. Planktonkde. 3: 60, figs. III ${ }^{1}-\mathrm{III}^{5}$. 1908.

Colonies spherical, ovoid, reniform or irregular; with a wide, hyaline, gelatinous envelope that is at times radially fibrillar in structure. Cells ovoid to ellipsoid, radially arranged in a single layer some distance beneath the periphery of the colonial envelope, usually elose together but not mutually compressed. Cell contents rarely homogeneous and pale to bright blue-green or grass-green; usually with numerous pseudovacuoles and reddish to brownish in color. (Euplanktont).

Cells $2-3 \mu$ broad; $3.5-6 \mu$ long.

Adelaide (ss), Amicoy (ss), Balsam (ss), Bear (1) (s), Bear (2) (rr), Bear (3) (s), Bear Trap (sss), Beaverdam (cc), Big (ccc), Big Butternut (r), Big McKenzie (ss), Big St. Germaine (rr), Birch (1) (ccc), Birch (2) (aa), Birch Island (rrr), Blake (rr), Bloom (ss), Bone (ss), Boulder (rr), Browns (rr), Camp (c), Catfish (aa), Center (aa), Chetac (aa), Clam (c), Clare (rr), Crab (sss), Cranberry (aa), Devils (1) (rr), Devils (2) (ss), Deer (rr), Duck (c), Dummy (rrr), Elizabeth (cc), Fish (sss), Found (ss), Fowler (ss), Granite (ss), Grindstone (rr), Half Moon (s), Hillman (s), Hooker (rr), Horseshoe (1) (ss), Horseshoe (2) (rrr), Island (cc), Jennie (rr), Kawaguesaga (sss), Kitten (rrr), Kegonsa (aa), Lac du Flambeau (rr), Lac la Belle (r), Laura (aa), Lindy (rr), Little Bass (2) (rr), Little Butternut (rr), Little Rice (1) (cc), Long (1) (rr), Long (2) (a), Loon ( $r r$ ), Lost (aa), Lower Nemahbin (r), Marl (rr), Mendota (cc), Mercer (ss), Middle McKenzle (cc), Mill (rr), Minocqua (rr), Monona (aa), Mud (1) (cc), Mud (3) (aa), Mudhen (rr), Nancy (c), Nicaboyne (r), No Mans (aa), North Twin (cc), North Turtle (aa), Number One (ss), Oconomowoc (rr), Okauchee 
(r), Otter (rr), Paddock (c), Palmer (ss), Pardee (rr), Pewaukee (ss), Plum (ss), Pokegama (1) (c), Pokegama (2) (sss), Pokegama (3) (a), Poplar (r), Prairie (s), Reserve (ss), Rainbow (r), Rice (1) (cc), Rock (a), Rooney (aa), Round (1) (rrr), Round (2) (ss), Round (3) (ss), St. Croix (cc), Sanford (r), Sand (1) (ss), Sand (2) (rr), Sand (3) (rr), Sand (4) (rr), Silver (2) (c), Sishebogema (aa), South Turtle (sss), Upper Nashotah (rr), Upper Nemahbin (rr), Upper Turtle (s), Wapagossett (cc), Waubesa (cc), White Ash (rr), Whitefish (cc), White Sand (rrr), Wildcat (rrr), Winnebago (cc), Wolf (rrr).

The radial fibrillar structure at the periphery of the gelatinous envelope is also found at times in the center of the colony. These radiations have been compared by some to the gelatinous strands found in Gomphosphaeria and the species transferred to that genus. I have preferred to keep the alga in the genus where it was first described. This alga is one of the important members of the Myxophyceae in the formation of blooms but it is rarely found as the sole constituent of any bloom. Bachmann's figures of the alga are quite characteristic.

\section{GOMPHOSPHAERIA Kützing 1836.}

Colonies microscopic, spherical to ellipsoid, embedded in a copious, hyaline, solid, homogeneous, gelatinous envelope. Cells spherical to pyriform, solitary or in pairs, generally lying some distance from one another and forming a layer one cell in thickness towards the periphery of the colonial envelope. Central portion of colonial envelope containing a denser core from which projections radiate to the base of the cells. Individual sheaths of cells distinct or confluent with the colonial envelope. Cell contents homogeneous, rarely granulose; grey to light or bright blue-green.

Reproduction by alternate vegetative division of cells in three planes.

KEY TO THE SPECIES.

Cells spherical .G. Lacustris Cells pyriform to cardioid .G. Aponina

\section{Gomphosphaeria lacustris Chodat. Pl. 4, Fig. 5.}

Bull. Herb. Boiss. 6: 180, figs. $1_{\mathrm{A}}-1_{\mathrm{G}}$. 1898; W. \& G. S. West, Trans. Roy. Irish Acad. 33, Sec. B: 112, pl. 11, figs. 24-27. 1906.

Colonies small, generally spherical or subspherical, rarely reniform; with a hyaline, homogeneous, gelatinous envelope. Cells spherical to broadly ellipsoid, irregularly spaced to form a single layer one cell in thickness beneath the periphery of the colonial envelope. Individual cell sheaths confluent with colonial envelope. Central portion of colony containing a core of denser radiating gelatinous strands that run 
to the base of the cells. Cell contents homogeneous; grey to pale or bright blue-green, rose colored in rare instances. (Euplanktont).

Cells $1.5-2.5 \mu$ broad, $1.5-4 \mu$ long. Colonies rarely over $40 \mu$ in diam.

Bear (1) (rr), Beaverdam (c), Big McKenzie (ss), Blake (sss), Cochrane (r), Deer (rr), Diamond (r), Dunham (c), Fish (c), Half Moon ( $r r$ ), Island (rr), Kawaguesaga (r), Lac Court Oreilles (ss), Lindy (sss), Little Bass (2) (rr), Long (1) (rr), Loon (rr), Mendota (s), Mercer (ss), Middle McKenzie (ss), Mudhen (ss), Nicaboyne (r), North Twin (r), Pardee (rr), Plum (rr), Pokegama (3) (rr), Sand (1) (r), Sand (2) (rr), Sand (4) (rr), Spirit (r), Squirrel (sss), Star (sss), Wolf (r).

The colonies of this species resemble those of Coelosphaerium Kuetzingianum in cell shape and arrangement but differ in the radiating strands of gelatinous material running from the center of the colony to the base of the cells. The gelatinous envelope is very delicate and cells frequently break away leaving the central mass of gelatinous radiations floating by itself.

Gomphosphaeria aponina Kützing. Pl. 4, Figs. 2-3.

Decades 16: No. 151. 1836; G. S. West, Brit. Freshw. Algae 349, fig. $163_{\mathrm{B}}$. 1904.

Colonies small, spherical to subspherical, with a fairly thick, hyaline, homogeneous, gelatinous envelope. Cells pyriform to cuneate, cardioid just before division; sparsely seattered and in a single layer some distance beneath the periphery of the colonial envelope. Individual sheaths of cells generally distinct, attached at the base to the dense gelatinous strands radiating from the center of the colony. Cell contents homogeneous or finely granulose; without pseudovacuoles; generally a bright blue-green. (Tychoplanktont).

Cells 4-5 $\mu$ wide at the greatest breadth, 8-15 $\mu$ long. Diam. colonies $50-90 \mu$.

Beaverdam (sss), Big McKenzie (rrr), Browns (rr), Center (rr), Eagle (rr), Elizabeth ( $r r)$, Hillman (rr), Kegonsa (rrr), Lower Nemahbin (rr), Mendota (rr), Mary (rr), Monona (rrr), Mudhen (rr), North Turtle (rrr), Otter (rrr), Pewaukee (rr), Pine (1) (rrr), Plum (rrr), Silver (2) (rr), Silver (3) (rr), South Turtle (rr), Waubesa (r).

var. CORdiformis Wolle. Pl. 4, Fig. 4.

Bull. Torr. Bot. Cl. 9: 25, pl. 13, fig. 11. 1882.

Cells considerably larger than in the typical form and markedly heart shaped instead of pyriform. Individual sheaths of cells conspicuous. Cell contents bright blue-green. (Tychoplanktont).

Greatest breadth of cells 6-13 $\mu$; length 9-20 $\mu$.

Bloom (rrr). 
The cells of the Wisconsin individuals are somewhat longer than Wolle found them, his measurements for the length of the cell varying from 9-16 $\mu$.

\section{MICROCYSTIS Kützing 1833.}

Colonies free-floating; spherical, elongate, irregular, or perforate to form reticulate or clathrate masses of microscopic or macroscopic size. Frequently occurring in sufficient quantities to give the water a verdigris-green color. Envelope of colonies generally copious, delicate to firm. Cells small, spherical, distributed in a solid mass throughout the colony and densely aggregated. Individual cell sheath confluent with colonial envelope. Cell contents homogeneous or with numerous pseudovacuoles; light to dark blue-green, olive-green, or rose colored.

Reproduction by vegetative division of cells in three directions.

Certain species of the genus occur in prodigious quantities and cause the familiar blooming of lakes. These species contain pseudovacuoles, while species without pseudovacuoles rarely occur in quantity.

\section{KEY TO THE SPECIES.}

Cells with numerous pseudovacuoles.

Several colonies enclosed by the same envelope........... Iснтновы.ABE

Colonies not differentiated into several within the same envelope.

Colony entire, not perforate.................... FLos-AQUAE

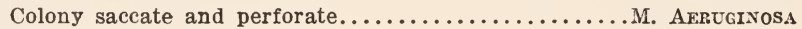

Cells without pseudovacuoles.

Diameter of cells less than $1.5 \mu \ldots \ldots \ldots \ldots \ldots \ldots \ldots \ldots \ldots \ldots \ldots \ldots \ldots \ldots$ INCERTA

Diameter of cells $2-3 \mu \ldots \ldots \ldots \ldots \ldots \ldots \ldots \ldots \ldots \ldots \ldots \ldots \ldots \ldots \ldots$. PuLVERA

\section{Microcystis ichthyoblabe Kützing.}

Phycol. generalis 170. 1843.

Polycystis ichthyoblabe Kützing, Tabulae Phycol. 1: 7, pl. 8. 1845.

Colonies spherical or irregular, fragmented into several distinct subcolonies, each with its own gelatinous envelope, and with the sub-colonies enclosed by a common gelatinous envelope. Cells spherical, close together. Individual cell sheaths confluent with colonial envelope. Cell contents pale to bright blue-green. Generally containing numerous pseudovacuoles. (Facultative Planktont).

Diam. cells $2-4 \mu$.

Catfish (rr), Clear (rr), Kawaguesaga (ss), Minocqua (r). 
Microcystis FloS-AqUaE (Wittrock) Kirchner. Pl. 5, Fig. 1. in Engler \& Prantl, D. nat. Pflanzenfam. 1 (Abt. 1a): 56, fig. $49_{\mathrm{N}^{*}} 1900$.

Colonies spherical to ovoid, rarely elongate; frequently reaching a macroscopic size. Cells compactly and evenly distributed within a very delicate, hyaline, homogeneous, gelatinous envelope. Margins of colony not sharply defined. Cell contents rarely homogeneous and grey to pale blue-green; usually with pseudovacuoles and reddish in color. Plant mass yellowish to verdigris-green. (Euplanktont).

Diam. cells 3.5-6.5 $\mu$.

Bear (2) (rr), Big St. Germain (rr), Birch (1) (c), Birch Island (sss), Browns (cc), Catfish (ss), Center (ss), Cochrane (sss), Duck (ss), Dunham (rr), Fishtrap (rr), Found (sss), Fowler (rr), High (rr), Horseshoe (1) (rr), Kegonsa (cc), Loveless (r), Lower Nashotah (rr), Lower Nemahbin ( $r$ ), Mendota (aa), Mercer (rrr), Monona (aa), Mud (3) (cc), Nagawicka (rr), No Mans (r), North Turtle (ss), Oconomowoc (ss), Paddock (ss), Palmer (ss), Pardee (ss), Plum (ss), Pokegama (1) (ss), Rainbow (r), Rock (s), Rose (ss), Sand (3) (r), Shell (rr), Sishebogema (ss), South Turtle (ss), Squirrel (rr), Star (ss), Tamarack (ss), Tenderfoot (rr), Upper Nashotah (rrr), Wapagossett (ss), Waubesa (ss), Whitefish (ss), Winnebago (cc).

\section{Microcystis aeruginosa Kützing. Pl. 5, Figs. 2-3.}

Tabulae Phycol. 1: 6, pl. 8. 1845.

Clathrocystis aeruginosa (Kützing) Henfrey, Trans. Micr. Soc. London N. S. 4: 53, pl. 4, figs. 28-36. 1856 (in Quart. Jour. Micr. Sci. 4: 1856): Bachmann, Arch. f. Hydrobiol. u. Planktonkde. 3: 61, figs. IV ${ }^{1}-I^{6}$. 1908.

Colonies spherical to subspherical when young, later becoming saceate and ultimately reticulate and clathrate. Gelatinous envelope of colony homogeneous, hyaline, and indistinct. Colonies frequently occurring in suficient quantity to color water a bright green. Cells spherical to subspherical, evenly distributed throughout the colony and close together. Cell contents rarely homogeneous and grey to pale or bright blue-green; usually with numerous pseudovacuoles and reddish. (Euplanktont).

Diam. cells 3-4 $\mu$.

Balsam (ss), Bear (3) (rr), Big Butternut (ss), Bloom (ccc), Bone (ss), Browns (cc), Center (rr), Clam (r), Crooked (rrr), Delavan (sss), Desmoines (ss), Devils (2) (rr), Duck (rr), Dutchmans (rrr), Eagle (ccc), Elizabeth (cc), Fish (ss), Fowler (rr), Grassy (ss), Grindstone (rr), Half Moon (ss), Hooker (ss), Horseshoe (1) (rr), Kawaguesaga (rr), Kegonsa (a), Kimball (ss), Lac du Flambeau (rr), Lac la Belle (rr), Lake of the Woods (r), Little Bass (2) (sss), Little Butternut (cc), Little Crooked (ss), Little Wood (ss), Loveless (ss), Mendota (a), Meronk (ss), Mill (sss), Monona (cc), Mud (2) (r), Mudhen (ss), Nancy (ss), Nicaboyne (ss), North Turtle (ss), North Twin (cc), Oconomowoc (rrr), Old Taylors (r), Otter (rr), Owen (rrr), Pardee (ss), Pewaukee (ss), Pokegama (2) (rr), Pokegama (3) (ss), Prairie 
(sss), Rice (1) (rr), Rooney (r), Sand (1) (ss), Sand (4) (rr), Shell (rr), Silver (2) (ss), Travis (rr), Upper Turtle (ss), Waubesa (cc), White Ash (ss), Wildeat (ss), Wolf (rr).

var. MAJOR (Wittrock) G. M. Smith. Pl. 4, Fig. 6.

Trans. Wis. Acad. Sci., Arts, \& Lett. 18²: 535. 1916.

Mature colonies elongate; irregular, saccate, or clathrate. Colonial envelope much firmer than in typical form and with larger cells. (Euplanktont).

Diam. cells 5.5-6.5 $\mu$.

Center (rr), Mendota (ss), Nancy (sss), St. Croix (rr), Vermilion (cc).

Microcystis incerta Lemmermann. Pl. 5, Fig. 4.

Abh. Naturw. Ver. Bremen 17: 342. 1903; Kryptogamenfl. d. Mark Brandenburg 3; Algen 1: 76, 44, fig. 12.1907.

Colonies spherical or somewhat elongate, enclosed by a hyaline, homogeneous, and very delicate gelatinous envelope. Cells small, very close together but equidistant from one another. Cell contents homogeneous, without pseudovacuoles; grey to pale blue-green in color. (Facultative Planktont).

Diam. cells 1-2 $\mu$.

Camp (rr), Chetek (r), Hooker (s), Prairie (r), Whitefish (rr), Winnebago (c).

The cells of this species are very similar in appearance to those found in Aphanocapsa elachista and A. delicatissima but their compact arrangement shows that the alga is a Microcystis and not an Aphanocapsa.

\section{Microcystis pulvera (Wood) Migula.}

in Thomé, Flora v. Deutschl., Deutsch.-österr. u. d. Schw. 6, Kryptogamen 2, Algen 1: 36. 1907.

Anacystis pulverus Wood. Wolle, Freshw. Algae of U. S. 329, pl. 210, fig. 25. 1887.

Colonies sphericaì or elongate, with a very delicate, hyaline, gelatinous envelope. Cells spherical, very closely crowded together and forming a solid mass. Cell contents homogeneous, without pseudovacuoles; grey, pale olive-green, or blue-green in color. (Facultative Planktont).

Diam. cells 2-3 $\mu$.

Browns (rr), Mill (rrr), Pardee (ss), Sunday (r), Winnebago (sss).

Since the specific difference between this and the foregoing species is mainly one of cell size it might be better to consider $\boldsymbol{M}$. incerta a variety of $M$. pulvera. 


\section{APHANOCAPSA Nägeli 1849.}

Cells united to form spherical, ovoid, or amorphous colonies of microscopic or macroscopic size. Colonies, hyaline, yellow, brown, or bluegreen in color. Cells spherical, equally distributed throughout the colony but always some distance from one another; generally solitary, rarely in clusters. Individual sheaths of cells confluent with the homogeneous, hyaline or colored, colonial envelope. Cell contents homogeneous; usually pale to bright blue-green or grey in color.

Reproduction by vegetative division of cells in three directions.

\section{KEY TO THE SPECIES.}

Cells growing within gelatinous envelope of other algae........ EndophrtrcA Cells forming free-floating or sessile colonies.

Cell contents grey to pale blue-green.

Diameter of cells $3.5-4.5 \mu \ldots \ldots \ldots \ldots \ldots \ldots \ldots \ldots \ldots \ldots \ldots \ldots \ldots \ldots \ldots \ldots$. Pulchra

Diameter of cells less than $3 \mu$.

Cell diameter not exceeding $1 \mu \ldots \ldots \ldots \ldots \ldots$. Dencatissima

Cell diameter $1.5-2.5 \mu \ldots \ldots \ldots \ldots \ldots \ldots \ldots \ldots \ldots . \ldots \ldots . \ldots \ldots$. El.Achista

Cell contents brightly colored, generally blue-green.

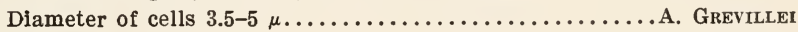

Diameter of cells $5-6 \mu \ldots \ldots \ldots \ldots \ldots \ldots \ldots \ldots \ldots \ldots \ldots \ldots \ldots \ldots \ldots$. RIVULARIS

\section{Aphanocapsa delicatissima W. \& G. S. West. Pl. 2, Fig. 7.} Jour. Linn. Soc. Bot. 40: 431, pl. 19, figs. 2-3. 1912.

Colonies small, spherical, ovoid or irregular, free-floating. Colonial envelope gelatinous, homogeneous, hyaline or ochraceous. Cells spherical, very small, more or less remote from one another. Cell contents homogeneous, grey to pale blue-green. (Euplanktont).

Cells .5-.75 $\mu$ in diam.; colonies 15-30 $\mu$ broad, 15-50 $\mu$ long.

Big Butternut (r), Chain (r), Little Butternut (ss), Loveless (ss), Mendota (s), Poor Farm (r).

The cells of this species are smaller than many bacteria and during the first two year's study of the plankton flora these small colonies were considered bacteria and not recorded so that the record for distribution is far from complete. When the colonies are of any considerable size the mass of cells has a decided blue-green color so that the organism must be called a blue-green bacterium or a blue-green alga of bacterial size. The latter view seems to be the more logical. It is very probable that the bacteria have been derived from the blue-green algae and the Wests' discovery of blue-green algae of bacterial size is very suggestive. 
Aphanocapsa elachista var. conferta W. \& G. S. West. Pl. 2, Fig. 8. Jour. Linn. Soc. Bot. 40: 432, pl. 19, fig. 1. 1912.

Colonies small, spherical, ovoid, or irregular; with the cells enclosed by a gelatinous, homogeneous, hyaline or ochraceous envelope. Individual sheaths of cells confluent with colonial envelope. Cells spherical, fairly close together. Cell contents homogeneous, grey to pale blue-green. (Euplanktont).

Diam. cells $1.6-2.0 \mu$. Colonies up to $75 \mu$ broad and $100 \mu$ long.

Birch Island (rr), Crawling Stone (rrr), Deer (ss), Lindy (r), Nancy (r), Pine Tree (ss), Silver (2) (rr).

var. planctonica var, nov. Pl. 3, Fig. 3 .

Cells spherical, some distance from one another. Sheath enclosing colony always hyaline. Contents of cells pale grey. (Euplanktont).

Diam. cells 2-3 $\mu$.

Bear (1) (s), Bear Trap (rr), Poplar (ss), Round (3) (rr), Sand (1) (r).

Differing from the typical form in the larger cell size and grey color of the cell contents.

Aphanocapsa endophytica sp. nov. Pl. 2, Fig. 10.

Colonies endophytic within the gelatinous sheath of Microcystis colonies and with their envelopes confluent with the envelope of the host colony. Cells spherical, equidistant from one another or in small clumps. Cell contents homogeneous, grey to bright blue-green. (Euplanktont).

Diam. cells $2 \mu$.

Poor Farm (ss).

The occurrence of bacteria in the gelatinous envelope of colonial Myxophyceae is a familiar phenomenon to the limnologist. The bluegreen color of the cells endophytic within the envelopes of Microcystis colonies in Poor Farm Lake precludes their recognition as bacteria. (See G. S. West's remarks concerning a similar endophytic Aphanothece in Jour. Linn. Soc. Bot. 40: 432. 1912).

Aphanocapsa pulchra (Kützing) Rabenhorst. Pl. 2, Fig. 9. Flora Eur. Algarum 2: 49. 1865.

Colonies macroscopic or microscopic, free-floating or sessile, generally spherical to ovoid when found in the plankton. Sheath of colony gelatinous, firm, hyaline, homogeneous; with the cells some distance from 
one another. Individual cell sheaths confluent with the colonial envelope. Cell contents homogeneous, grey to pale blue-green. (Tychoplanktont).

Diam. cells $3.5-4.5 \mu$.

Beaver (r), Beaverdam (sss), Harris (rrr), Lac Court Oreilles (ss), Winnebago (rr).

Aphanocapsa grevillei (Hassall) Rabenhorst. Pl. 3, Fig. 1.

Flora Eur. Algarum 2: 50. 1865; G. S. West, Brit. Freshw. Algae, 351, fig. $165_{\mathrm{A}^{*}} 1904$.

Colonies free-floating or sessile; spherical to ellipsoid when free-floating, dirty green in color. Cells spherical, solitary or in pairs and somewhat crowded. Cell contents homogeneous or finely granulose, bright blue-green in color. (Facultative Planktont).

Diam. cells $3.5-5 \mu$.

Beaverdam (rr), Birch (ss), Camp (ss), Chetac (sss), Muskallonge (rr), Rice (1) (rr), Silver (1) (rrr), Whitefish (ss).

Aphanocapsa rivularis (Carm.) Rabenhorst. Pl. 3, Fig. 2.

Flora Eur. Algarum 2: 49. 1865; Cooke, Brit. Freshw. Algae 210, pl. 86, fig. 2. 1884.

Colonies free-floating or sessile; spherical, tubular, or irregular in shape. Cells spherical, solitary or in pairs and some distance from one another within the colony. Individual sheaths of cells confluent with the hyaline, homogeneous, colonial envelope. Cell contents homogeneous or finely granulose; bright blue-green in color. (Tychoplanktont).

Diam. cells 5-6 $\mu$.

Star (rrr).

\section{APHANOTHECE Nägeli 1849.}

Colonies free-floating, sessile, or endophytic; spherical or expanded into amorphous masses and enclosed by a firm, copious, homogeneous, hyaline or colored envelope. Cells oblong to cylindrical, with rounded ends. Cells forming a solid mass distributed throughout the coloniai envelope but lying some distance from one another. Individual cell sheaths indistinct, confluent with the colonial envelope. Cell contents homogeneous or finely granulose, never with pseudovacuoles; grey, light to bright blue-green, or olive-green in color.

Reproduction by vegetative division of cells in three planes, but with cell divisions always taking place at right angles to the long axes of cells. 
KEY TO THE SPECIES.

Colonies endophytic in gelatinous envelope of other algae..

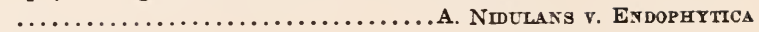

Colonies not endophytic.

Cell contents grey to pale blue-green, never bright blue-green.

Colonies ovoid to spherical, never perforate............ Niduravs

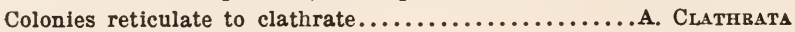

Cell contents bright blue-green.

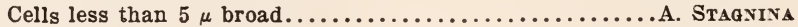

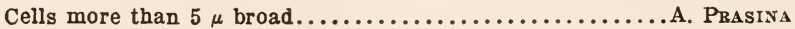

Aphanothece clathrata W. \& G. S. West. Pl. 6, Fig. 3.

Trans. Roy. Irish Acad. 32, Sec. B: 111, pl. 10, figs. 9-11. 1906.

Colonies microscopic; free-floating; elongate and irregular in shape, usually perforate and reticulate. Gelatinous colonial envelope hyaline and homogeneous. Cells very small, bacilliform, straight or curved, embedded in a solid mass in the colonial envelope. Cell contents homogeneous, grey to light blue-green. (Euplanktont).

Cells $0.6-1.0 \mu$ broad, $3.5-4.5 \mu$ long.

Lindy (r), Little Crooked (sss), Nancy (ss), Pokegama (1) (r), Poor Farm (rr), Sand (1) (ss), Wolf (ss).

Aphanothece nidulans P. Richter. Pl. 6, Fig. 1.

Bot. Not. 1884 : 128.1884.

Colonies spherical, ovoid, or "nest-shaped"; enclosed by a homogeneous, hyaline, gelatinous envelope. Cells broadly cylindrical, straight or curved, of small size and fairly close together. Individual sheaths of cells confluent with the colonial envelope. Cell contents homogeneous, grey to light blue-green. (Facultative Planktont).

Cells 1.0-1.5 $\mu$ broad, up to $3.5 \mu$ long.

Beaver (2) (ss), Deer (ss), Lower McKenzie (sss), Pokegama (sss), Tenderfoot $(r)$.

Certain species of this genus resemble bacterial colonies in much the same manner as the minute-celled species of Aphanocapsa. Here again the color of the cell contents is good evidence of the algal nature of the organism.

var. endophytica W. \& G. S. West. Pl. 5, Fig. 6.

Jour. Linn. Soc. Bot. 40: 432, pt. 19, fig. 14. 1912.

Cells embedded in gelatinous envelope of other colonial Myxophyceae. Gelatinous envelope of colony confluent with envelope of host 
colony. Cells narrow, at least twice as long as they are broad. Cell contents homogeneous; generally light blue-green, rarely grey. (Euplanktont).

Cells $0.8-1.5 \mu$ broad, $2.5-4.5 \mu$ long.

Endophytic in sheaths of Coelosphaerium Kuetzingianum and MicroCystis aeruginosa.

Birch Island (r), Chetac (ss), Round (3) (rr).

\section{Aphanothece prasina A. Braun. Pl. 5, Fig. 5.}

In Rabenhorst, Flora Eur. Algarum 2: 65. 1865; Cooke, Brit. Freshw. Algae, 218, pl. 88, figs. 3a-3b. 1884.

Colonies spherical to cylindrical, reaching a diameter of $3-4 \mathrm{~cm}$. under favorable conditions; bright green in color. Cells evenly distributed throughout the colony, broadly cylindrical and with rounded ends. Individual cell sheaths confluent with the colonial envelope. Cell contents homogeneous, bright blue-green. (Tychoplanktont).

Cells 5-6.5 $\mu$ broad, 7.7-11 $\mu$ long.

Beaverdam (r), Nancy (rr), Pokegama (1) (rrr).

The determination of this and the following species is open to question since specific differences in these species are based in part upon the macroscopic appearance of the colony when growing attached to the substratum. The determination of plankton species is from immature colonies and must rest upon cell shape, size, and color.

Aphanothece stagnina (Sprengel) A. Braun. Pl. 6, Fig. 2.

in Rabenhorst, Algen No. 1572; Cooke, Brit. Freshw. Algae 219, pl. 88, fig. 4. 1884 .

Colony spherical, ellipsoidal, or cylindrical; generally macroscopic, $0.5-20 \mathrm{~mm}$ in diameter, pale verdigris-green. Cells broadly cylindrical, their length never more than $1 \frac{1}{2}$ times their breadth. Individual sheaths of cells confluent with the hyaline, homogeneous, gelatinous, colonial envelope. Cell contents homogeneous; pale to bright bluegreen. (Tychoplanktont).

Cells $3-5 \mu$ broad; $5-8 \mu$ long.

Lake of the Woods (rr), Whitefish (rr).

\section{GLOEOTHECE Nägeli 1849.}

Colonies free-floating or sessile, of comparatively few cells enclosed by a hyaline or variously colored, homogeneous, gelatinous envelope. Individual sheaths of cells prominent, homogeneous or slightly lamel- 
lated, sometimes 2-8 cells enclosed by a single sheath. Cells elongate to broadly cylindrical, with rounded ends and irregularly distributed throughout the colonial envelope or with their longer axes pointing in the same general direction. Cell contents homogeneous or finely granulose; grey, pale to bright blue-green, or olive green in color.

Reproduction by vegetative division of cells at right angles to their long axes.

Gloeothece linearis Nägeli. Pl. 6, Fig. 5.

Gatt. einz. Algen 58, pl. 1, fig. G' 1849.

Colonies small; dull yellow to flesh color or dirty olive-green; enclosed by a broad, hyaline, homogeneous, gelatinous envelope. Cells elongate-cylindrical, straight or arcuate, with rounded ends. Sheaths containing one cell only, broad, hyaline, having the same general outline as the cell. Cell contents homogeneous; pale to bright blue-green. (Tychoplanktont).

Cells (without sheath) $1.3-2.5 \mu$ broad, 10.5-18 $\mu$ long; (with sheath) 4-6 $\mu$ broad, 13-22 $\mu$ long.

Harris ( $r$ ), Muskallonge (rr).

var. composita var. nov. Pl. 6, Fig. 6.

Cells shorter and 2-8 enclosed by a single, broad, firm, homogeneous sheath. Individual sheaths of single cells or groups of cells not confluent with the colonial envelope. (Tychoplanktont).

Cells (without sheath) 3.0-3.5 $\mu$ broad, 4-8 $\mu$ long; sheaths 10-12 $\mu$ broad, 20-35 $\mu$ long.

Deer (rrr).

RHABDODERMA Schmidle and Lauterborn. 1900.

Colonies free-floating, small, of comparatively few cells enclosed by a hyaline, homogeneous, gelatinous envelope. Cells cylindrical, with rounded apices, straight or arcuate; with their long axes pointing in the same general direction. Individual sheaths of cells confluent with colonial envelope. Cell contents homogeneous; grey to bright bluegreen in color.

Reproduction by vegetative division of cells, the divisions taking place at right angles to the long axes of the cells. 
Rhabdoderma lineare Schmidle and Lauterborn. Pl. 6, Fig. 4. Ber. d. D. Bot. Ges. 18: 148, pl. 6, figs. 8-11. 1900.

Specific characters as those of the genus. (Euplanktont). Cells $2-3 \mu$ broad, 6-12 $\mu$ long.

Sand (2) (rrr), Whitefish (rr).

This genus is closely related to Gloeothece, the chief difference being a lack of individual sheaths around the cells.

\section{DACTYLOCOCCOPSIS Hansgirg 1888.}

Colonies microscopic, free-floating or lying among other algae; embedded in a copious, hyaline, homogeneous, acicular to fusiform, gelatinous envelope. Cells elongate, acicular and with pointed ends; straight arcuate, sigmoid, or spirally twisted around one another. Individual cell sheaths confluent with colonial envelope. Cell contents homogeneous or with the color bearing area localized in a definite part of the cell; grey to bright blue-green in color.

Reproduction by vegetative division of cells at right angles to their long axes.

\section{KEY TO THE SPECIES.}

Length of cells never more than sixteen times the breadth, cells frequently bent $\ldots \ldots \ldots \ldots \ldots \ldots \ldots \ldots \ldots \ldots \ldots \ldots \ldots \ldots \ldots \ldots$. RAPHIDIOIDKS Length of cells at least twenty times the breadth, cells al-

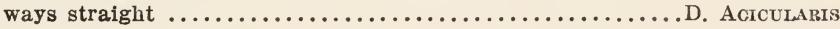

\section{DaCtylococcopsis Rhaphidioides Hansgirg. Pl. 6, Fig. 7.}

Prodr. d. Algenfl. v. Böhmen 139, fig. 49A. 1892; Lemmermann, Kryptogamenfl. d. Mark Brandenburg 3, Algen 1: 50. 1907.

Colonies containing 2-8 or more cells. Cells fusiform ; straight, arcuate or sigmoid; frequently in pairs with one end rounded and the other pointed. Colonies enclosed by a copious, hyaline, homogeneous envelope. Cell contents homogeneous, pale blue-green. (Facultative Planktont).

Cells 1-3 $\mu$ broad, 5-25 $\mu$ long.

Deer (sss), Long (2) (rrr), Mercer (rr), Reserve (rr), Rice (1) (rr).

Hansgirg gives eight as the maximal number of cells found in the colony but I have observed colonies in which there are as many as a 
hundred cells. These cells are also proportionally longer than he states and may be, in extreme cases, sixteen times as long as they are broad. In this respect they follow the cell dimensions delimited by Lemmermann.

Dactylococcopsis acicularis Lemmermann. Pl. 6, Figs. 8-10.

Ber. d. D. Bot. Ges. 18: 309. 1900; Kryptogamenfl. d. Mark Brandenburg 3, Algen 1: 51, 44, fig. 5. 1907.

Cells solitary or in colonies enclosed by a wide, hyaline, homogeneous, gelatinous sheath. Cells' elongate, acicular, with poles attenuated to fine points; straight or slightly arcuate. Cell contents homogeneous and pale blue-green; or with color bearing region restricted to one side of cell. (Euplanktont).

Cells 2-2.5 $\mu$ broad, 55-80 $\mu$ long.

Browns (cc).

The localization of the color bearing portion at one side of the cell is quite abnormal for a member of the Myxophyceae, but, as I have stated elsewhere (Trans. Wis. Acad. Sci., Arts, \& Lett. 1919:620. 1918) notwithstanding this fact the alga belongs to the Myxophyceae.

\section{Order HORMOGONEALES.}

Cells always in filaments that generally contain a number of cells. Filaments simple or branched; solitary or united to form definitely wr indefinitely shaped aggregates. Free-floating, sessile, epiphytic, or endophytic. Cells serially arranged to form trichomes, which when enclosed by a sheath are known as filaments. Trichomes either the same thickness throughout, attenuated towards both extremities, or attenuated from base to apex; straight, arcuate, spirally or irregularly twisted. Sheaths of filaments tough and leathery; or gelatinous, homogeneous to lamellated, hyaline to variously colored, and distinct or confluent with the colonial envelope. Cell shape various. Cell contents homogeneous, or with numerous pseudovacuoles; grey, light to dark bluegreen, olive-green, reddish-green, ochraceous, orange, violet, or black in color.

Reproduction, aside from vegetative cell division, by hormogones and resting spores. 


\section{KEY TO THE FAMILIES.}

Trichomes without heterocysts* . Oscillatoriaceae Trichomes with heterocysts.

Trichomes not attenuated Nostocaceae Trichomes attenuated to a hair-like point RIVULARIACEAE

\section{Family OSCILLATORIACEAE.}

Trichomes free-floating, sessile, epiphytic, or endophytic; of one or more cells forming simple or branched filaments with one or more trichomes within a single sheath. Sheaths of various forms; copious, gelatinous, hyaline or colored, homogeneous to lamellated; firm, narrow and homogeneous or lamellated; or entirely lacking. Filaments straight or spirally twisted. Cells disciform, cylindrical, or barrelshaped. Apical cell of trichomes frequently conical and capitate. Heterocysts never present in the trichomes. Cell contents homogeneous, granulose, or with pseudovacuoles; variously colored.

Reproduction by vegetative division of cells and the formation of hormogones.

KEY TO THE GENERA.

Trichomes solitary or in flocculent, readily dissociating masses.

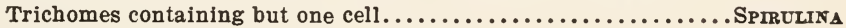

Trichomes containing more than one cell.

Sheaths of filaments firm, generally projecting beyond

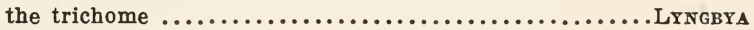

Sheaths delicate or lacking, not projecting beyond

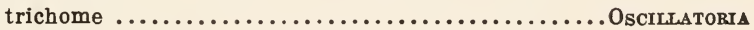

Trichomes laterally united to form free-floating bundles which

do not dissociate readily .................... TRICHODESMIUM

\section{SPIRULINA Turpin 1827.}

Trichome consisting of a single, elongate, cylindrical cell that is not attenuated but with rounded ends. Filaments without sheaths and twisted to form loose or compact regular spirals. Cell contents homogeneous or granulose; light to dark blue-green in color.

Reproduction by vegetative division of cells at right angles to the long axis. No hormogone formation possible.

*Cells commonly larger than the vegetative cells and with heavy walls that have a conspicuous nodule at each pole. Cell contents a homogeneous, pellucid, non-cytoplasmic substance. 


\section{KEY TO THE SPECIES.}

Turns of spirals not over $5 \mu$ in diameter...................... MAsoB Turns of spirals over $10 \mu$ in diameter..................... PRIrckePs

\section{SpIrulina MaJor Kützing. Pl. 7, Fig. 1.}

Phycol. generalis 183. 1843; Gomont, Ann. Sci. Nat. 7 Sér., Bot. 16: 251, pl. 7, flg. 29. 1892.

Filaments free-floating and solitary, or forming a greenish seum. Trichomes in a more or less loose spiral that is straight or bent. Cell contents homogeneous; bright blue-green. Sheath of filament lacking. (Tychoplanktont).

Trichomes 1.2-1.7 $\mu$ in diameter. Spirals 2.5-4 $\mu$ broad, 2.7-5 $\mu$ between turns.

White Ash (rrr).

Spirulina Princeps (W. \& G. S. West) G. S. West emend. Pl. 7, Fig. 2. Jour. Linn. Soc. Bot. 38: 179, pl. 9, fig. 5. 1907; W. \& G. S. West, Trans. Linn. Soc. Bot. 2 Ser., Bot. 6: 205.1902.

Trichomes solitary, in loose spirals that may be straight or curved. Ends of trichomes blunt or rounded. Cell contents homogeneous or with a few scattered granules; bright blue-green. (Tychoplanktont).

Trichomes $3-5 \mu$ broad. Spirals 8.8-16 $\mu$ broad, 9.5-12 $\mu$ between turns.

Poor Farm (rrr).

\section{OSCILLATORIA Vaucher 1803.}

Trichomes possessing a peculiar power of spontaneous movement of an oscillating, rolling, or gliding type; free-floating; solitary or in flocculent masses; sometimes forming strata in moist places. Trichomes unbranched, eylindrical, entirely without or with barely perceptible sheaths. Ends of trichomes straight, slightly attenuated, but never attenuated to a point. Terminal cells rounded or calyptrate. Cell shape cylindrical to disciform. Cell contents usually homogeneous or granulose, rarely with pseudovacuoles. Color of cells variable.

Reproduction by hormogones. 
KEY TO THE SPECIES.

Apex of trichome gradually tapering................... Prolifica Apex of trichome not tapering $\ldots \ldots \ldots \ldots \ldots \ldots \ldots \ldots \ldots \ldots \ldots \ldots \ldots \ldots$. Tenuis

Oscillatoria prolifica (Greville) Gomont. Pl. 7, Figs. 3-5. Ann. Sci. Nat. 7 Sér. Bot. 16: 205, pl. 6, fig. 8. 1892; Olive, Trans. Wis. Acad. Sci., Arts, \& Lett. 15 ${ }^{1}$ : 124-134. 1905; Hyams and Richards, Technology Quart. 14: 302-310, figs. 1-8. 1901.

Filaments rarely solitary, generally irregularly matted to form freeHoating flocculent masses. Plant masses blood-red to dirty purple, becoming lilac when dried. Trichomes straight, elongate, not constricted at cross walls of cells, and slightly tapered at apex with the terminal cell of mature trichomes obtuse-capitate. Cells cylindrical, slightly longer than they are broad. Cell contents with numerous reddish pseudovacuoles, sometimes with rows of granules at the eross walls. (Euplanktont).

Cells $2.2-5 \mu$ broad, $4-6 \mu$ long.

Geneva (aa), Pine (1) (aa).

This species is closely related to 0 . rubescens D. C., but if Gomont's monograph of the Oscillatoriaceae must be taken as the starting point for nomenclature of the group the two are distinct. Both species are peculiar in that they produce blooms in lakes at a time when the water is very cold or covered with ice. The masses of filaments do not have the usual yellowish-green color but are blood red to dirty purple and the phenomenon is spoken of in Europe as "bloody" or "Burgundy" bloom.

Olive has described the occurrence of such a bloom in Pine lake of this state and discussed the literature of the subject. The alga also appeared in profusion in Lake Geneva this (1918) spring at the time when the ice was beginning to disappear. It was not frozen in the ice but grew luxuriantly in the water below the ice and gave a deep reddish color that was especially noticeable in the cracks between the ice. The alga had not been noted in the lake before this time and its sporadic appearance is quite like the sporadic appearance of 0 . rubescens in the Swiss lakes. The excessive growth of $O$. prolifica is not wholly correlated with cold water since it has remained present throughout the summer, but not in such quantities as early in the spring. This abundant growth of the alga in the summer has also been noted in a Massachusetts lake by Hyams and Richards and furnishes a physiological as well as a morphological distinction between $O$. prolifica and $O$. rubescens. 
Oscillatoria tenuis C. A. Agardh. Pl. 7, Fig. 6.

Algarum decades 2: 25. 1813; Gomont, Ann. Sci. Nat. 7 Sér. Bot. 16: 220, pl. 7, figs. 2-3. 1892.

Filaments solitary or in flocese masses that are pale blue-green in color. Trichomes straight, slightly constricted at the cross walls. Terminal cells the same diameter as those in the median portion of the trichome, straight or curved; apical cells rounded but not capitate. Cell shape disciform. Cell contents homogeneous except for a row of granules along the cross walls. (Tychoplanktont).

Cells 4-10 $\mu$ broad, $2.6-5 \mu$ long.

Monona ( $\mathrm{rr})$.

var. Tergestina (Kützing) Rabenhorst. Pl. 7, Figs. 7-8.

Flora Eur. Algarum 2: 102. 1865.

Trichomes narrower than the foregoing. (Tychoplanktont).

Cells 4-6 $\mu$ broad.

Geneva (ss).

LYNGBYA C. A. Agardh. 1824.

Filaments solitary or interwoven to form floceose masses; free-floating or in an expanded stratum. Sheaths of filaments narrow, firm, hyaline or colored, homogeneous or lamellated, generally projecting for some distance beyond the trichome. Filaments unbranched, cylin. drical; straight, flexed, or twisted into regular spirals. Trichomes generally the same thickness throughout, rarely slightly attenuated at the apices; sometimes constricted at the cross walls. Apical cell with distal end rounded or slightly eapitate. Cell contents homogeneous, granulose, or with numerous pseudovacuoles; grey, pale to bright blue-green or variously colored.

Reproduction by the formation of hormogones.

KEY TO THE SPECIES.

Filaments not over $4 \mu$ in thickness, with pale blue-green to grey cell contents.

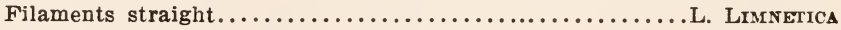
Filaments in regularly coiled spirals................... Contorta Filaments over $10 \mu$ in diameter, contents deeply colored........... BrRgeI

Lyngbia limnetica Lemmermann. Pl. 7, Figs. 9-11.

Bot. Cent. 76: 154. 1898; Kryptogamenfl. d. Mark Brandenburg 3, Algen 1: 135, 102, fig. 8. 1907.

Filaments free-floating, generally solitary; straight or slightly flexed. Trichomes not constricted at the cross walls. Apical cells the same 
thickness as the other cells, with distal end rounded but not capitate. Sheaths firm, hyaline, very narrow, extending for some distance beyond the end of the trichome. Cells cylindrical, at least twice as long as broad. Cell contents homogeneous; generally grey, rarely blue-green in color. (Euplanktont).

Cells 1-1.5 $\mu$ broad, 3-8 $\mu$ long.

Bear (1) (c), Geneva (ss), Soft (rr), Upper Nashotah (rrr).

The length of the individual cells of Wisconsin specimens exceeds that given by Lemmermann but it is very probable that I am dealing with the same species that he names $L$. limnetica. Several plankton "species" have been described which are closely related and it is very probable that future investigations will show that all of these straight, very narrow, colorless "species" should be included under one collective specific name.

\section{Lyngbya contorta Lemmermann. Pl. 7, Figs. 12-13.}

Forschungsbr. a. d. Biol. Stat. zu Plön 6: 202, pl. 5, figs. 10-13. 1898; G. S. West Jour. of Bot. 47: 246, pl. 498, figs. $5_{\mathrm{A}} \mathbf{5}_{\mathrm{B}^{*}} 1909$.

Filaments free-floating, solitary; occasionally straight, generally twisted to form regular, loose or compact spirals or helices. Sheaths firm, very thin, extending for some distance beyond the trichomes. Trichomes the same thickness throughout, not constricted at the cross walls, apical cells rounded but not capitate at the distal ends. Cell contents homogeneous, grey to pale blue-green. (Euplanktont).

Cells 1.5-2 $\mu$ broad, 3-6 $\mu$ long. Spirals 15-20 $\mu$ broad, 6-14 $\mu$ between the turns.

Mendota (rr), Pine Tree (ss), Poor Farm (s), White Ash (cc).

The specific distinction of this species is based in large part upon the spiral twisting of the filament. Since certain normally straight filaments of other algae become spirally twisted under limnetic conditions (vide W. \& G. S. West, Proc. Roy. Soc. London Ser. B, 81: 169, fig. 1. 1909) the validity of spiral twisting as a specific character arises. $L$. contorta was found in considerable quantity at different stations and the vast majority of filaments were spirally twisted. On the other band numerous filaments with cells of the same size that showed no signs of twisting were collected from other stations. I think that Lemmermann is correct in considering these distinct species and that the spiral twisting of filaments in plankton species of the Myxophyceae is a sufficiently constant character to warrant the establishment of species in both this genus and Anabaena. 


\section{Lyngbya birgei G. M. Smith. Pl. 7, Figs. 14-15.}

Bull. Torr. Bot. Cl. 43: 482, pl. 26, fig. 28. 1916.

Filaments free-floating, solitary, never forming floceose masses; straight or slightly flexed. Sheaths firm, at times of considerable thickness, hyaline, generally homogeneous, rarely lamellated, extending for some distance beyond the trichome. Trichomes not attenuated at apices and without constrictions at the cross walls. Terminal cells rounded but not capitate at distal ends. Cell shape disciform. Cell contents rarely homogeneous and with grey to olive green contents; usually with numerous pseudovacuoles. (Euplanktont).

Cells 18-23 $\mu$ broad, 2-5.5 long. Sheaths .5-4 $\mu$ thick.

Balsam (rr), Bear Trap (cc), Big (cc), Deer (rrr), Elizabeth (ss), Fowler (rrr), Half Moon (c), Kegonsa (aa), Lac la Belle (rr), Little Crooked (r), Little Wood (rr), Loveless ( $r r$ ), Lower Nashotah ( $r r)$, Mary (ss), Mendota (cc), Mercer ( $r r)$, Monona (cc), Mudhen ( $r r$ ), Nagawicka (rr), Oconomowoc (rr), Pope (rrr), Round (3) (sss), Sand (1) (r), Spirit (sss), Squirrel (sss), Upper Nashotah (cc), Upper Turtle (rr), Wapagossett (cc), Waubesa (cc), Wolf $(r)$.

This is undoubtedly the alga that Trelease (Trans. Wis. Acad. Sci., Arts, \& Lett. 7: 124, pl. 10, fig. 6. 1888) reported from Lake Mendota as Lyngbya Wollei Farlow. L. Wollei has been shown to be a Plectonema ( $P$. Wollei Farlow) and Trelease's determination is undoubtedly a mistake.

\section{TRICHODESMIUM Ehrenberg 1830.}

Trichomes laterally joined to form spindle- to scale-shaped, freefloating colonies that are not enclosed by a gelatinous sheath. Trichomes cylindrical, straight or spirally twisted, of the same thickness throughout or with apices slightly attenuated. Apical cell undifferentiated, or rounded and slightly capitate. Sheaths of trichomes very delicate. Cells disciform to barrel-shaped. Cell contents homogeneous, granulose, or with numerous pseudovacuoles. Heterocysts and resting spores lacking.

Reproduction by the formation of hormogones.

Trichodesmium lacustre Klebahn. Pl. 8, Fig. 1.

Forschungsbr. a. d. Biol. Stat. zu Plön 3: 13. 1895; Flora 80: 271, pl. 4, flgs. 31-33. 1895.

Trichomes laterally joined to form plate-like, free-floating masses that are not enclosed by a gelatinous envelope. Filaments with a very delicate, homogeneous sheath. Trichomes straight, not attenuated at the apices, and with terminal cells rounded but not capitate. Cells 
disciform, with straight or markedly convex sides. Cell contents occasionally homogeneous and pale to bright blue-green in color; generally with numerous pseudovacuoles. Trichomes without heterocysts or spores. (Euplanktont).

Cells 5-7 $\mu$ broad, 5-7 $\mu$ long. Colonies up to $1 \mathrm{~mm}$. in length.

Amicoy (rrr), Beaverdam (r), Island (rr), Lake of the Woods (rrr), Little Bass (1) (rr), Mud (1) (s), Nicaboyne (rr), Rice (1) (rr), Wild Goose (rrr).

The general appearance of the colony at once suggests an Aphanizomenon species with cells shorter and more rounded than the familiar A. flos-aquae. I have examined a sufficient number of colonies to feel confident in confirming Klebahn's statement that there are no spores or heterocysts in the alga under consideration. This being the case it is impossible to refer the species to Aphanizomenon, but it should be considered a freshwater species of the common Trichodesmium of tropical seas.

\section{Family NOSTOCACEAE.}

Filaments free-floating, sessile, epiphytic, or endophytic; solitary or in colonies of microscopic to macroscopic size that are definitely or indefinitely shaped. Trichomes always unbranched; straight, flexed, spirally twisted, or irregularly interwoven. Sheath rarely firm and narrow; generally copious, gelatinous, hyaline or colored, and distinct or confluent with the colonial envelope. Trichomes generally the same thickness throughout and with spherical to cylindrical cells. Heterocysts either terminal or intercalary, solitary or catenate. Resting spores variously shaped, adjacent to or remote from the heterocysts; formed in all genera. Cell contents homogeneous, granulose, or with pseudovacuoles; grey or variously colored.

Reproduction by fragmentation of colony, hormogones, and resting spores.

\section{KEY TO THE GENERA.}

Trichomes solitary or interwoven to form flocculent masses of

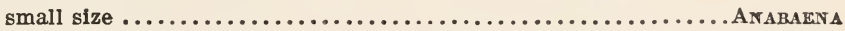
Trichomes laterally joined to form small plate-like colonies.... AphaNizomenoN

\section{ANABAENA Bory 1822.}

Filaments free-floating or forming a delicate mucous layer; solitary or in floccose colonies. Trichomes the same thickness throughout or slightly attenuated at the apices; straight, spiral, circinate, or aggregated without definite order. Sheaths delicate or copious, gelatinous, hyaline, homogeneous, rarely confluent with the colonial envelope; some- 
times entirely lacking. Cells spherical to barrel-shaped, rarely cylindrical, never disciform. Heterocysts approximately spherical, always intercalary, generally solitary and with several in a filament. Spores variously shaped, contiguous to or remote from heterocysts, solitary or in short catenate series. Cell contents homogeneous, granulose, or with numerous pseudovacuoles; grey, blue-green, or variously colored.

Reproduction by hormogones and spores.

\section{KEY TO THE SPECIES.}

Filaments straight or slightly curved.

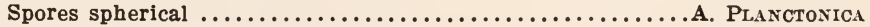

Spores longer than they are broad.

Length of spores not over twice their breadth.

Breadth of spores less than twice that of vegetative cells.

Spores oval to elliptic in optical cross section.

Vegetative cells less than $8 \mu$ broad.................A. Arfinis

Vegetative cells over $10 \mu$ broad.................. Limmetica

Spores hexagonal in optical cross section.............. MAcrosporA

Breadth of spores more than twice the vegetative cells.....A. LEVANDERI

Length of spores at least three times their breadth ........... BobNETIANA Fylaments spirally, circinately, or irregularly twisted.

Trichomes solitary, not forming floccose masses.

Curving of trichome a definite spiral................. SpIBordes

Curving of trichome not a definite spiral.

Length of spore at least four times breadth..A. Augstumalis I. C. Marchia

Length of spore about twice the breadth............... Cracinalis

Trichomes forming a floccose mass.

Spores in a mass at center of colony................ LeMMERMIANMI

Spores not in a mass at the center of the colony.

Trichomes loosely associated, individual filaments some-

times in spiral turns..............................mcinalis

Trichomes greatly and irregularly twisted to form com-

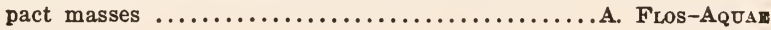

Anabaena planctonica Brunnthaler. Pl. 8, Fig. 2.

Siizenbr. d. kais. Ak. d. Wiss. Wien 112, Abt. 1: 292.1903.

Filaments free-floating, solitary, straight, or slightly bent. Trichomes enclosed by a copious, hyaline, very gelatinous sheath. Vegetative cells spherical, hemispherical, or broadly elliptic. Heterocysts spherical. Spores solitary, remote from or adjacent to heterocysts, spherical or slightly elongate, somewhat broader than the vegetative cells. Cell contents rarely homogeneous, usually with numerous pseudovacuoles. (Euplanktont).

Vegetative cells $9-15 \mu$ broad; heterocysts $12-14 \mu$ broad; spores 12.5-20 $\mu$ broad, 12.5-30 $\mu$ long.

Birch (1) (cc), Center («c), Cranberry (cc), Devils (2) (ss), Rock (cc). 
Many juvenile spores of other speeies are spherical but the spores of this species never become appreciably elongated.

\section{Anabaend affinis Lemmermann. Pl. 8, Fig. 7.}

Abh. Nat. Ver. Bremen 14: 261, pl. 1, figs. 12-13, 16-17. 1897.

Filaments solitary, free-floating, straight or slightly flexed; with a wide, homogeneous, hyaline, faintly discernible gelatinous envelope. Mature vegetative cells generally spherical; rarely with homogeneous contents, usually with pseudovacuoles. Heterocysts spherical. Spores generally remote from heterocysts, short or elongate cylindrical, with rounded ends and covered with a thick, smooth wall. (Facultative planktont).

Cells 5-6 $\mu$ broad; heterocysts 7.5-10 $\mu$ broad; spores $9.5-12 \mu$ broad, 17-26 $\mu$ long.

Lindy (rr), Lost (rr), North Turtle (c), Pardee (sss), Poplar (ss), Sand (1) (s).

\section{Anabaena limnetica G. M. Smith. Pl. 8, Fig. 8.}

Bull. Torr. Bot. Cl. 43: 481, pl. 26, fig. 27. 1916.

Filaments free-floating, solitary, straight or slightly flexed; with a copious, homogeneous, hyaline sheath. Vegetative cells spherical or with poles flattened. Heterocysts spherical. Spores smooth-walled, solitary, broadly ovoid, remote from or adjacent to the heterocysts. Cell contents rarely homogeneous, generally with numerous pseudovacuoles. (Euplanktont).

Cells $12-15 \mu$ broad; heterocysts $10-14 \mu$ broad; spores $17-20 \mu$ broad, 20-30 $\mu$ long.

Bear Trap (ss), Birch (1) (cc), Soft (ss), Tamarack (cc), White Ash (ss).

Anabaena Macrospora var. robusta Lemmermann. Pl. 8, Fig. 6. Bot. Cent. 76: 154. 1898.

Filaments solitary, free-floating, straight or slightly bent, frequently attaining a considerable length; with a copious, hyaline, homogeneous, gelatinous envelope. Mature vegetative cells spherical or subspherical with flattened ends. Heterocysts spherical. Spores solitary or in pairs, adjacent to or remote from heterocysts, cylindrical with conical ends and hexagonal in optical cross section. Spore wall smooth and thick. Cells containing numerous pseudovacuoles. (Euplanktont).

Cells 12-16 $\mu$ broad, 9-12 $\mu$ long; heterocysts $12-16 \mu$ broad; spores 17-19 $\mu$ broad, $30-34 \mu$ long.

Camp (cc), Squirrel (ss). 
Anabaena Levanderi Lemmermann. Pl. 8, Figs. 4-5.

Ber. d. D. Bot. Ges. 24: 536. 1906.

Filaments solitary, free-floating, straight or slightly flexed, not enclosed by a gelatinous sheath. Trichomes cylindrical, slightly constricted at the cross walls of the cells. Vegetative cells twice as long as they are broad, cylindrical, with rounded ends. Heterocysts hyaline, spherical or ellipsoid. Spores solitary, adjacent to or remote from the heterocysts, twice as broad as the vegetative cells, ellipsoid in shape. Cell contents rarely homogeneous and pale blue-green to grey; usually with numerous pseudovacuoles. (Euplanktont).

Cells 4-6 $\mu$ broad, 11-33 $\mu$ long; heterocysts 6.5-8 $\mu$ broad, 6.5-9.5 $\mu$ long; spores $8-15 \mu$ broad, $19-45 \mu$ long.

Chain (sss).

The dimensions of all specimens found in Chain lake have been near the minimal limits set by Lemmermann.

\section{Anabaena Bornetiana Collins. Pl. 8, Fig. 3.}

Erythrea 4: 120.1896.

Filaments free-floating, straight or slightly curved. Vegetative cells spherical or slightly shorter than they are broad, with homogeneous pale blue-green contents. Sheaths of trichomes very delicate. Heterocysts spherical to elongate. Spores elongate cylindrical, with rounded ends, adjacent to and on both sides of, or remote from the heterocysts. (Tychoplanktont).

Vegetative cells $12 \mu$ broad; heterocysts $13-14 \mu$ broad, $13-20 \mu$ long; spores 15-20 $\mu$ broad, 50-90 $\mu$ long.

George (rr).

Only a few filaments of this species were found in George lake and these contained but few spores which were not always adjacent to the heterocysts. The species may, therefore, not be A. Bornetiana for Collins states that the spores are always adjacent to the heterocysts.

Anabaena augstumalis var. marchica Lemmermann. Pl. 8, Figs. 9-10. Forschungsbr. a. d. Biol. Stat. zu Plön 12: 147. 1905.

Filaments solitary, free-floating, more or less bent but not circinate, without a gelatinous envelope. Vegetative cells spherical, broadly ellipsoid or cylindrical; with numerous pseudovacuoles. Heterocysts spherical or slightly elongate. Spores remote from heterocysts, elongate cylin- 
drical, with rounded ends. Spore wall delicate, smooth, and hyaline. (Facultative planktont).

Cells 5-7 $\mu$ broad, 5-9.5 $\mu$ long; heterocysts 8-9.5 $\mu$ broad, 8-14 $\mu$ long; spores $9.5-12 \mu$ broad, 40-70 $\mu$ long.

Bone (ss), Center (cc).

Anabaena spiroides var. Crassa Lemmermann. Pl. 9, Figs. 1-3.

Bot. Cent. 76: 155. 1898; Kryptogamenfl. d. Mark. Brandenburg 3, Algen 1: 188, 159, figs. 15-16. 1907.

Filaments solitary, free-floating; forming a regular, evenly spaced spiral enclosed by a very transparent, homogeneous, gelatinous envelope. Cells spherical or with flattened ends. Heterocysts spherical, hyaline or pale yellow. Spores solitary, remote from the heterocysts, generally broadly ovoid. Cell contents rarely homogeneous, usually with numerous pseudovacuoles. (Euplanktont).

Cells 11-15 $\mu$ broad; heterocysts $10-17 \mu$ broad; spores $20-25 \mu$ broad, $27-42$ (generally 27-31) $\mu$ long. Spirals $50-60 \mu$ broad and $45-55 \mu$ between turns.

Big Butternut (cc), Big St. Germain (cc), Granite (cc), Hooker (c), Kegonsa (a), Long (2) (sss), Little Butternut (cc), Mendota (cc), Monona (aa), North Twin (sss), Round (3) (ss), South Turtle (c), Vermilion (ccc).

Anabaena circinalis (Kützing)Rabenhorst. Pl. 9, Figs. 4-5.

Algen No. 209. 1852; Phillips, Grevillea 9: 5, pl. 134, figs. e-g. 1880; Bornet et Flahault, Ann. Sci. Nat. 7 Sér. Bot. 7: 230. 1888.

Anabaena Hassallii (Kützing) Wittrock. Bot. Not. 1882: 58. 1882.

Filaments free-floating, rarely solitary, curved or sigmoid; usually greatly and irregularly twisted to form floccose masses. Filaments with or without a copious, hyaline, gelatinous envelope. Cells spherical or appreciably flattened at the poles, generally with numerous pseudovacuoles. Heterocysts spherical to subspherical. Spores usually remote from the heterocysts, cylindrical, with rounded ends when mature, frequently curved and with smooth walls. (Euplanktont).

Cells 8-14 $\mu$ broad; heterocysts $8-10 \mu$ broad; spores $16-18 \mu$ broad, 26-30 $\mu$ long when mature.

Center (ss), Chain (sss), Lac la Belle (rr), Mercer (rr), Nagawicka (rr), Pike (r), Upper Nashotah ( $r r$ ), Wapagossett (sss), Winnebago (ss).

This species differs from $A$. flos-aquae in the loose looping of the trichomes, the larger vegetative cells and the broader spores. 
var. MACroSPORA (Wittrock) de Toni. Pl. 9, Fig. 6; Pl. 10, Fig. 1. Sylloge algarum 5: 445. 1907.

Anabaena Hassallii var. macrospora Wittrock, Bot. Not. 1882: 59, figs. 7-9. 1882.

Vegetative cells somewhat smaller but with much narrower and proportionally longer spores.

Cells $7-8 \mu$ broad; heterocysts $7.5-10 \mu$ broad; spores $9-10.5 \mu$ broad, $28-42 \mu$ long.

Camp (sss).

Anabaena flos-aquae (Lyngbye) de Brebisson. Pl. 10, Figs. 2-4.

Mém. de la soc. Acad. de Falaise 1835: 36. 1836; Kützing, Tabulae Phycol. 1: 51, pl. 94, fig. 4. 1848; Bornet et Flahault, Ann. Sci. Nat. 7 Sêr. Bot. 7: 228. 1888.

Filaments free-floating, densely coiled, irregularly twisted and interwoven to form a floccose colony. Cells spherical or cylindrical with convex sides; generally containing numerous pseudovacuoles. Heterocysts broader and longer than the vegetative cells. Spores cylindrical, with rounded ends, usually curved, solitary or in short catenulate series; generally adjacent to, rarely remote from the heterocysts. (Euplanktont).

Vegetative cells 4-8 (generally 5.5) $\mu$ broad; heterocysts $6-9 \mu$ broad; spores 7-13 $\mu$ broad, 20-50 $\mu$ long.

Bear (1) (cc), Birch Island (r), Browns (cc), Camp (ss), Catfish (ss), Catherine (rr), Cochrane (sss), Crab (r), Crawling Stone (rrr), Crooked (sss), Des Molnes ( $r r)$, Devils (1) ( $r$ ), Eagle (sss), Fish (rr), Grassy (r), Green (2) (sss), Half Moon (rr), Hooker ( $r$ ), Horse (rrr), Jag (rr), Jennie (ss), Kegonsa (rr), Lac Court Oreilles (ss), Lac la Belle (r), Little Crooked (rr), Little Wood ( $r$ ), Long (1) ( $r r$ ), Long (3) ( $r r$ ), Lower Nashotah ( $r r$ ), Lynx (Sss), Mary (rr), Mendota (c), Mercer (rr), Mill (rr) Mud (2) (c), Nancy (s), Oconomowoc (r), Okauchee (rr), Palmer (rr), Pine Tree (rr), Poplar (rr), Round (1) (rr), Round (3) (r), Rudolph (rrr), Sanford (c), Shell (rrr), Sishebogema (rr), South Crab (rr), Squirrel (rr), Upper Nashotah (r), Upper Nemahbin (rr), Waubesa (c), Wildcat (sss), Wolf (r).

\section{var. Treleasi Bornet et Flahault. Pl. 10, Figs. 5-7.}

Ann. Sci. Nat. 7 Sêr. Bot. 7 : 230. 1888.

Anabaena mendotae Trelease, Trans. Wis. Acad. Sci., Arts, \& Lett. 7: 123, pl. 10, fig. 5. 1889.

Cells smaller and with spores somewhat narrower and proportionally longer. (Euplanktont).

Vegetative cells $3-5 \mu$ broad, $4.5-12 \mu$ long; heterocysts $4.5-6 \mu$ broad, 6-8 $\mu$ long; spores $6-8 \mu$ broad, $20-40 \mu$ long.

Mendota (aa), Waubesa (s). 
Anabaena Lemmermanni P. Richter. Pl. 10, Fig. 8; Pl. 11, Fig. 1.

Forschungsbr. a. d. Biol. Stat. zu Plön 10: 153. 1903.

Anabaena flos-aquae Klebahn non (Lyngbye) de Breb., Flora 80: 267, pl. 4, tigs. 21-22. 1895.

Filaments free-floating; irregularly or circinately interwoven to form a spherical or broadly ellipsoid mass, with filaments frequently radiating in loops from a common center. Vegetative cells spherical or slightly elongate, usually containing numerous pseudovacuoles. Heterocysts spherical, approximately the same size as the vegetative cells. Spores cylindrical, with rounded ends, with inner side straight and the outer convex; rarely remote from heterocysts, generally forming short catenate series' on both sides of heterocysts and lying in a dense mass at the center of the colony. The spore masses and heterocysts frequently persisting long after the disappearance of the vegetative cells. (Euplanktont).

Vegetative cells $5.5-7 \mu$ broad, 5-8 $\mu$ long; heterocysts 6-7.5 $\mu$ broad; spores 8-11 $\mu$ broad, 19-33 $\mu$ long.

Crawling Stone (rr), Diamond (r), Kawaguesaga (rr), Long (rr), Marl (r), Oconomowoc (r), Paddock (cc), Palmer (r), Pardee (ss), Rainbow (2) (rr), Reserve (r), Rice (1) (s), Sand (2) (rr), Taylor (ss), Trout (s).

The species differs from $A$. flos-aquae in the regular looping of the trichomes from a common center and the development of a large mass of spores at the center of the colony. The persistence of the spores after the disappearance of the vegetative cells is very common and certain of the records for the species are based upon observation of the spore masses only.

\section{APHANIZOMENON Morren 1838.}

Trichomes straight slightly flexed, or curved; in lateral contact with one another to form small, macroscopic, free-floating, feathery, plate or scale-like opaque colonies. Trichomes destitute of a gelatinous sheath, sometimes constricted at cross walls of cells, and slightly attenuated at the apices. Cells cylindrical, with flattened ends. Heterocysts intercalary, cylindrical. Spores elongate, cylindrical and with flattened ends; solitary, adjacent to or remote from the heterocysts.

Reproduction by the formation of hormogones and resting spores.

Aphanizomenon flos-aquae (L)Ralfs. Pl. 11, Figs. 2-4.

Ann. \& Mag. of Nat. Hist. 2 Ser. 5: 340, pl. 9, fig. 6. 1850; Klebahn, Flora 80: 271, pl. 4, figs. 27-30. 1895.

Trichomes straight or slightly curved, laterally joined to form a flat flake- or scale-like plate. Cells cylindrical, with flattened ends, about 
three times as long as they are broad, generally with numerous pseudovacuoles. Heterocysts cylindrical, with straight or slightly convex sides, without a distinct polar nodule. Spores elongate, cylindrical, with rounded or somewhat flattened ends, generally some distance from the heterocysts. (Euplanktont).

Cells 4-6 $\mu$ broad, 5-15 $\mu$ long; heterocysts 5-7 $\mu$ broad, 7-20 $\mu$ long; spores $6-8 \mu$ broad, $35-80 \mu$ long.

Amicoy (aa), Balsam (ss), Bear (3) (rr), Beaverdam (rr), Big (r), Big Butternut (rr), Birch (1) (c), Bone (rr), Camp (r), Catfish (sss), Center (rrr), Chetac (aaa), Cranberry (ss), Crawling Stone (rrr), Deer (rrr), Dunham (rr), Found (rr), Fowler (rr), Granite (a), Green (2) (ss), Half Moon (sss), Hillman (sss), Hooker (cc), Horse (rrr), Horseshoe (1) (rr), Island (c), Kawaguesaga (ccc), Kegonsa (cc), Lac la Belle (rr), Little Bass (2) (rr), Little Butternut (s), Little Rice (1) (s), Little Wood (rr), Long (3) (rr), Lost (ss), Loveless (ss), Lower Nashotah (rr), Mendota (s), Mud (3) (rr), Nagawicka (rr), North Twin (rrr), Oconomowoc (rr), Okauchee (rr), Pardee (cc), Pewaukee (rr), Pike (rr), Plum (r), Pokegama (2) (rrr), Pokegama (3) (aaa), Poplar (rrr), Prairie (aaa), Reserve (rr), Rice (1) (ss), Round (1) (sss), Round (2) (ss), St. Croix (ccc), Sand (1) (r), Sand (3) (r), Sand (4) (r), Sahford (sss), Shell (rrr), South Turtle (sss), Squirrel (a), Streitor (rr), Tied Canoe (sss), Upper Nashotah (rr), Upper Nemahbin (r), Upper Turtle (rr), Vermilion ( $r$ ), Waubesa ( $s$ ), White Ash (rr), Whitefish (rr), White Sand (ss), Winnebago ( $r$ ).

When the alga occurs in any quantity the lake appears to be filled with small pieces of macerated grass and it is one of the few plankton genera that can be determined without the aid of a microscope. The colony is so opague that the heterocysts cannot be seen while the colony is intact but after a mount has been standing a few minutes the colonies begin to dissociate into the component filaments and observation of the heterocysts and spores is then an easy matter. The colonies are frequently sterile and it is generally only during the colder months of the year that there is a formation of spores.

\section{Family RIVULARIACEAE.}

Filaments rareìy solitary, generally forming sessile or free-floating spherical, hemispherical, or amorphous colonies. Trichomes gradually attenuated from a broad basal cell to a hair-like apical cell. Sheaths copious, homogeneous or lamellated, hyaline or colored, firm or gelatinous; enclosing one or more trichomes. Cells hemispherical, spherical, or disciform with convex sides at the basal portion of the trichome, elongate cylindrical in the apical region. Cell contents variously colored; homogeneous, granulose, or with numerous pseudovacuoles. Trichomes simple or with "false branching". Heterocysts solitary; usually 
at base of trichomes, rarely intercalary. Spores, when present, solitary and adjacent to heterocysts.

Reproduction by formation of trichomes and spores.

\section{GLOEOTRICHIA J. G. Agardh 1842.}

Filaments always in colonies; free-floating or sessile; spherical to hemispherical, tough and leathery to gelatinous, hyaline or colored. Trichomes attenuated to fine hair-like processes at the distal end, enclosed by gelatinous sheaths that are distinct at the base and confluent at the apex. Filaments containing one trichome, but at times showing false branching. Heterocysts spherical to hemispherical, solitary; at the base of the trichomes. Spores cylindrical, solitary, always adjacent to the heterocysts. Vegetative cells convexly disciform to short cylindrical at base of trichomes, elongate cylindrical with straight sides at apex of trichomes.

Reproduction by hormogones and resting spores.

\section{Gloeotrichia echinulata (J. E. Smith) P. Richter. Pl. 11, Figs. 5-6.}

Forschungsbr. a. d. Biol. Stat. zu Plön 2: 31, figs. 1-8. 1894.

Conferva echinulata J. E. Smith, Eng. Bot., pl. 1378. 1804.

Rivularia echinulata J. E. Smith, Eng. Bot. index; P. Richter, Forschungsbr. a. d. Biol. Stat. zu Plön 2: 45. 1894; Lemmermann, Kryptogamenfl. d. Mark Brandenburg 3, Algen 1: 255, 245, figs. 1, 6. 1907.

Gloeotrichia pisum Bornet et Flahault (p.p.) non Thuret, Bull. Soc. Bot. France 31: 80. 1884; Ann. Sci. Nat. 7 Sér. Bot. 4: 366 . 1886; Trelease, Trans. Wis. Acad. Sci., Arts, \& Lett. 7 : 124-125 (with fig.) 1889.

Colonies always free-floating, spherical; up to $2 \mathrm{~mm}$. in diameter. Filaments radially arranged about a common center but becoming irregular in arrangement on slight pressure. Sheaths hyaline, homogeneous, distinct at base, apex frequently confluent with colonial envelope. Trichomes broad at base, attenuated to long, colorless, hair-like processes. Lowest vegetative cell of trichome hemispherical; those a short distance from base disciform with markedly convex sides; those in middle of trichome cylindrical; while the cells in the apical region are elongate cylindrical. Basal cells completely filled with cytoplasm, apical cells with cytoplasm restricted to the median portion. Cell contents rarely homogeneous, usually with numerous pseudovacuoles. Heterocysts at base of trichome, spherical. Spores, when present, adjacent to heterocysts, elongate cylindrical with rounded ends.

Cells at base of trichome 8-10 $\mu$ broad; at apex 1-2 $\mu$ broad; heteroeysts $7-10 \mu$ broad; spores $8-10 \mu$ broad, $40-54 \mu$ long.

Bass (3) (rr), Bear (3) (rr), Bear Trap (rr), Beaverdam (rr), Birch (2) (ss), Birch Island (r), Bone (rr), Carroll (rr), Catherine (sss), Chetac (ss), 
Clare (ss), Crawling Stone (rrr), Des Moines (cc), Diamond (ss), Duck (rr), Dummy (rr), Dutchmans (ss), Fish (ss), Fowler (sss), Grindstone (rr), Half Moon (ss), Horseshoe (1) (ss), Horseshoe (2) (rr), Howey (rr), Island (ss), Jennie (rr), Kegonsa (aa), Kimball (rr), Lac Court Oreilles (ss), Lake of the Woods ( $r$ ), Lindy (rr), Long (1) (sss), Loon ( $r$ ), Mendota (s), Monona (cc), Nancy (ss), North Twin (r), Mercer (rrr), Middle McKenzie (ss), Mud (3) (aa), Oconomowoc ( $r r$ ), Owen (rrr), Razorback (aa), Reserve (rr), St. Croix (rr), Sand (1) (rr), Sand (3) (rr), Shell (rr), Soft (rr), Trout (cc), Waubesa (cc), Whitefish (sss), Wild Goose (rr), Winnebago (r).

A bloom of this alga can be recognized at once by the minute seed-like colonies surrounded by an aureole of whitish threads. It was first noted by Davis in England in 1804 and the plant figured and described by Smith in his English Botany. The various references to the alga before the recognition of a definite plankton flora have been compiled by Bornet and Flahault as well as P. Richter. Since the study of the plankton flora by phycologists the alga has been found in the lakes of inost European countries. Although there seems to be but a single species of the Rivulariaceae found free-floating in lakes and ponds the nomenclatorial treatment of this species is quite varied. Bornet and Flahault affirm that it is the common Gloeotrichia pisum, which ordinarily grows attached to submerged plants along the shore, that has broken away and become free-floating. They hold that Rivularia echinulata J. E. Smith (whose dimensions are the same as those of G. pisum) is nothing but a free-floating $G$. pisum. In my observations on the algae of our lakes there is no correlation between the appearance of $G$. pisum and G. echinulata in the same lake in Wisconsin. In the region of Madison, $G$. pisum does not appear until the middle of July and yet at one time there was a heavy bloom of $G$. echinulata on the 28 th of June, a time when there was no G. pisum along the shore. I am convinced that the sessile Gloeotrichia is not the one found in the plankton and that Richter is quite right in reviving the old specific name echinulata. Some investigators hold that Gloeotrichia is but a sub-genus of Rivularia, but I have followed Bornet and Flahault in considering the two distinct. This distinction is based upon the occurrence of spores in Gloeotrichia and a lack of spores in Rivularia. 


\section{Class PHAEOPHYCEAE.}

Plants usually of macroscopic size and definitely shaped. Cells variously shaped and containing brown chromatophores in which a brown pigment, phaeophycin, masks the chlorophyll. Cell wall not conspicucusly impregnated with silica and cells generally immobile in the vegetative phases.

Asexual reproduction by vegetative cell division, aplanospores, and zoospores.

Sexual reproduction by isogamous zoogametes; or heterogamous with a fusion of zoogametes of unequal size, or a union of a large immobile oosphere and a small motile antherozooid.

All of the complex non-motile members of this class are marine and only unicellular or simple colonial forms are found in fresh waters. These freshwater forms have the motile phase dominant, as a rule, and form the subclass Chrysomonadineae of the Phaeophyceae. Many place all of the colorless or brown chromatophored motile unicellular organisms in a class by themselves, the Flagellatae, but, as I have stated elsewhere, the group of the Chrysomonadineae seems sufficiently related to the Phaeophyceae to warrant uniting the two.

\section{Sub-class CHRYSOMONADINEAE.}

Cells with one or more definite, disciform, laminate, or reticulate, golden-brown chromatophores. Cells free-swimming or sessile, solitary or in colonies of definite to indefinite shape. Life cycle generally with the motile phase dominant but sometimes developing into amorphous or rhizopodial palmella stages. Cells either naked or with a gelatinous to definitely constituted periplast. Individual cells with 1-2 anterior or lateral cilia of equal or unequal length; 1-10 contractile vacuoles, generally at the anterior end; with or without an eyespot; and with one or more chromatophores. Symmetry of cells bilateral, not interrupted by a lateral or longitudinal grooving. Nutrition holophytic or saprophytic; assimilation product leucosin or fat, never starch.

Asexual reproduction by longitudinal or transverse division of cells. Resting stages with heavy walls known in many genera.

Sexual reproduction as yet unknown in the sub-class. 


\section{KEY TO THE DIVISIONS.}

Motile phase dominant, rhizopodial or palmella phase rare.EUCHRYSOMONADINAE Immobile phase dominant, motile phase known or unknown.

Cells spherical to ovoid, embedded in a gelatinous envelope... HrdruriNaE

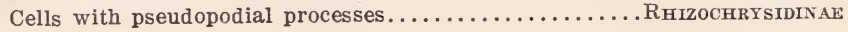

\section{Division EUCHRYSOIMONADINAE.}

Cell structure and organization as noted in the description of the sub-class. Ciliate phase dominating the life history. Palmella or rhizopodial phases known but not the general rule.

\section{KEY TO THE ORDERS.}

Motile phase with one flagellum Chromulinales Motile phase with two flagella.

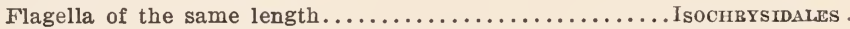

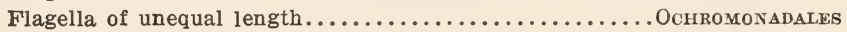

\section{Order CHRONIULINALES.}

Cells generally solitary, rarely colonial; free-floating or sessile. Motile phase with a single apical flagellum. Chromatophores reticulate, laminate, or disciform; generally two in each cell. Apical contractile vacuoles present or lacking. Cells either naked or with a definite, homogeneous or sculptured periplast.

Reproduction by vegetative division of cells. Thick-walled resting stages known in certain genera.

\section{KEY TO THE FAMILIES.}

Cells naked . Euchromulinaceae Cells with a differentiated periplast . MALLOMONADACEAR

\section{Family EUCHROMULINACEAE.}

Cells naked, without a differentiation of the periplast. Cells with sharply defined disciform to laminate chromatophores, and without contractile vacuoles. Flagellum single.

There are several genera with many species in the family but only one of them, Chrysamoeba, has been noted in the plankton of the state. 


\section{CHRYSAMOEBA Klebs 1893.}

Cells solitary, free-floating, with a mono-flagellate motile phase and an amoeboid non-motile phase. Motile phase broadly ovoid, naked, with two elongate, laminate, golden-brown chromatophores; a large ron-contractile vacuole, 2-3 small contractile vacuoles; and a single flagellum slightly longer than the cell. Eye-spot lacking.

Non-motile phase solitary or in small clumps, with several simple or branching pseudopodial processes extending in all directions. Chromatophores and vacuoles as in the motile phase.

\section{Chrysamoeba radians Klebs. Pl. 12, Fig. 1.}

Zeits. f. wiss. Zool. 55: 406, pl. 18, figs. 1a-1b. 1893.

Specific characters as described above. (Euplanktont).

Motile phase 8-10 $\mu$ broad, 12-15 $\mu$ long; amoeboid phase (without processes) $12-17 \mu$ broad, (with processes) $35-40 \mu$ broad.

Round (4) (rr), Taylor (rr).

\section{Family MALLOMONADACEAE.}

Cells always free-swimming, solitary or colonial, never metamorphosing into a palmella or rhizopodial phase. Periplast of cells or colonial envelope with numerous small plates of silica that have long, siliceous, needle-like processes. Cells ovoid to ellipsoid, with one flagellum, a number of contractile vacuoles and two long laminate chromatophores.

KEY TO THE GENERA.

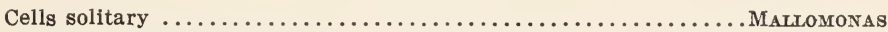
Cells in spherical colonies

.Chrysosphakrella

\section{MALLOMONAS Perty 1852.}

Cells always solitary, free-swimming, with a single flagellum at the anterior end. Periplast of cells with small circular or angular siliceous dises covering the entire surface of the cell or restricted to one or both ends. Scales frequently arranged in regular transverse or diagonal rows, produced into a single, long, simple or toothed, needle-like setae. Cells containing one or more contractile vacuoles that may be apical, median, or basal in position. Chromatophores two, parietal, laminate, and golden-brown in color. Assimilation product leucosin.

Reproduction by vegetative cell division parallel to the long axis. Akinetes known in many species. 


\section{KEY TO THE SPECIES.}

Setae restricted to one end of the cell.

Apical end with setae.

Cells cylindrical. M. Alpina

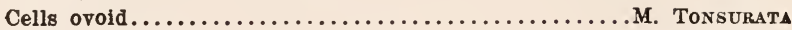

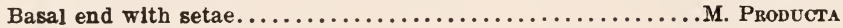

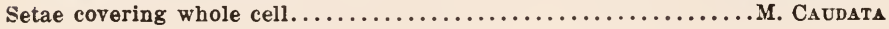

\section{Mallomonas alpina Pascher \& Ruttner. Pl. 12, Fig. 4.}

in Pascher, D. Süsswasserfl. Deutschl., Österr., u. d. Schw. 2, Flagellatae 2: 36, fig. 58A. 1913.

Cells ellipsoid to elongate cylindrical, with poles rounded or pointed. Scales rhomboidal, in diagonal rows; with a single, long, straight or curved seta. Setae confined to anterior end of cells. (Euplanktont).

Cells 8-12 $\mu$ broad, 25-45 $\mu$ long.

Camp (r).

\section{Mallomonas producta (Zacharias) Iwanoff. Pl. 12, Fig. 2.}

Bull. de l'Acad. Imp. d. Sc. de St. Pétersbourg 5 Sér., 11: 250, pl. A, figs. 4-6. 1899.

Cells cylindrical, with straight or slightly convex sides, ends rounded and tapering. Scales in regular transverse to diagonal rows, diamondshaped or laterally elongate. Setae straight or bent, confined to basal portion of cell. Chromatophores two, golden-brown, laminate, and parietal. (Euplanktont).

Cells 9-13 $\mu$ broad, 40-70 $\mu$ long.

Catfish (sss), Cranberry (ss), Crawling Stone (sss), Lac la Belle (ss), Long (1) (ss), Otter (r), South Turtle (rrr), Upper Nashotah (rr).

\section{var. MARCHICA Lemmermamn. Pl. 12, Fig. 3.}

Zeits. f. Fischeri 1903: 106. 1903.

Cells shorter and relatively broader. Setae sometimes at both ends of cells. (Euplanktont).

Cells 11-12 $\mu$ broad, 21-26 $\mu$ long.

Nancy (r), Oconomowoc (ss), Tamarack (ss).

\section{Mallomonas tonsurata Teiling. Pl. 12, Fig. 5.}

Sv. Bot. Tids. 6: 277, fig. 3. 1912.

Cells ellipsoid, with posterior end rounded and anterior end pointed. Setae confined to anterior third of cell, fairly short and somewhat curved. Scales not regularly arranged. (Euplanktont).

Cells $7-8 \mu$ broad, about $18 \mu$ long.

Waupaca (rr). 


\section{Mallomonas caudata Iwanoff. Pl. 12, Fig. 6.}

Bull. de l'Acad. Imp. d. Sc. de St. Pétersbourg 5 Sér., 11: 250, Pl. B, Ags. 1-8. 1899.

Cells broadly ovoid, with posterior end narrower than the anterior. Scales oval, arranged in transverse series. Setae long, covering the entire surface of the cell and frequently with minute teeth-like projections at the distal end. Cells with two long, parietal, laminate, chromatophores. (Euplanktont).

Cells $12-30 \mu$ broad, $40-85 \mu$ long.

Beasley (rr), Birch (1) (rrr), Browns (rr), Carson (rrr), Catherine (rr), Clare (r), Clear Crooked (rr), Crab (rr), Crawling Stone (rrr), Diamond (rrr), Hill (ss), Jennie (rr), Kitten (sss), Lac la Belle (ss), Long (3) (ss), Long (4) (rr), Lynx (rr), Mud (2) (ss), No Mans (s), North Turtle (r), Okauchee (rr), Otter (sss), Pokegama (1) (rr), Pokegama (2) (r), Red Bass (s), Rock (cc), Round (1) (sss), Rudolph (sss), St. Croix (rrr), Sand (4) (sss), Sanford (sss), South Crab (rr), Wildcat (sss), Wild Goose (rr), Wolf ( $r r)$.

\section{CHRYSOSPHAERELLA Lauterborn 1896.}

Cells ellipsoid to pyriform, in spherical colonies of microseopic size that are partially embedded in a spherical, hyaline, gelatinous envelope containing numerous, tangentially placed, minute plates of silica. Anterior ends of cells with two short, vase-shaped projections, each bearing a single, long, straight, siliceous seta of some length. Cells with one anterior flagellum; two elongate, parietal, golden-brown chromatophores; and several vacuoles.

Reproduction by vegetative cell division. Resting akinetes unknown.

\section{Chrysosphaerella longispina Lauterborn. Pl. 12, Figs. 7-8.}

Zool. Anz. 19: 16. 1896; Zeits. f. wiss. Zool. 65: 381, pl. 18, figs. 12-16. 1899.

Specific characters as described above. (Euplanktont).

Average breadth of cells $9 \mu$, average length $15 \mu$. Colonies $50-250 \mu$ in. diam.

Bettine (rr), Blue Gill (ss), Boulder (rrr), Canteen (r), Elizabeth (rr), Hill (aa), Lac la Belle (rr), Long (4) (rr), Lynx (r), Marl (rr), Mary (ss), No Mans (rr), Oconomowoc (ss), Okauchee (s), Otter (ss), Rainbow (ss), Round (4) (rr), Rudolph (sss), Silver (2) (ss), South Turtle (ec), Upper Nemahbin (ss), Wild Goose (cce).

\section{Order ISOCHRYSIDALES.}

Cells free-floating or sessile, solitary or colonial, naked or with a definite homogeneous or sculptured periplast. Motile phase always present, palmella or rhizopodial phase lacking. Cells variously shaped, 
always with two apical cilia of equal length; generally with two laminate, parietal, golden-brown chromatophores and without an eyespot.

The only family represented in the flora of the state is that of the Euhymenomonadaceae.

\section{Family EUHYMENOMONADACEAE.}

Differing from other families of the order in having a definite sculptured periplast and an anterior vacuolar system. Synura the sole representative.

\section{SYNURA Ehrenberg 1838.}

Cells radially arranged in spherical to oblong-ovoid free-swimming colonies that are not enclosed by a gelatinous sheath. Individual cells broadly pyriform, with the narrower end towards the center of the colony. Outer portion of cells firm, with small spines, reticulations, or combinations of the two. Cells with two long anterior cilia of equal length, several vacuoles, two long laminate parietal chromatophores, and without an eyespot.

Reproduction by division of cells and liberation of cell contents to form amoeboid cells. Akinete formation also known.

Synura uvella Ehrenberg. Pl. 12, Figs. 9-10.

Infusionsthierchen $61, p l .3$, figs. $9^{2}-9^{5}$. 1838.

Exterior of cells covered with fine spines that are generally limited to the anterior portion. (Facultative Planktont).

Cells 8-17 $\mu$ broad, 20-35 $\mu$ broad. Colonies up to $350 \mu$ in diam.

Camp (ss), Canteen (cc), Crawling Stone (rrr), Fowler (cc), Jenny (rr), Kawaguesaga (rr), Little Bear (rrr), Little Crooked (rr), Long (3) ( $r$ ), Lower Nemahbin (rr), Lynx (r), Mendota (ss), Mercer (rr), Mill (ccc), Mud (2) (rr), Nagawicka (cc), Nancy (cc), Nicaboyne (rr), No Mans (cc), North Turtle (rr), Oconomowoc (s), Palmer (c), Pardee (sss), Pewaukee (sss), Pope (rrr), Rainbow (1) (rr), Red Bass (ss), Round (1) (sss), Rudolph (sss), Sand (4) (rr), Sanford (ss), South Turtle (rr).

\section{Order OCHROMONADALES.}

Cells solitary or colonial, free-swimming or sessile, not forming palmella or rhizopodial stages. Cells naked, or with a definitely shaped receptacle; two lateral or apical cilia of unequal length, one or two goldenbrown disciform to laminate chromatophores; contractile vacuoles; and an eyespot. 
KEY TO THE FAMILIES.

Cells naked, at times in a gelatinous envelope but never a

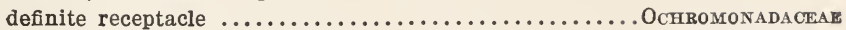

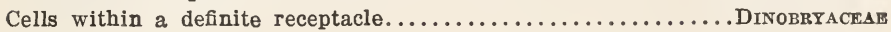

\section{Family OCHROMONADACEAE.}

Cells solitary or in colonies, always free-swimming, not enclosed by a definite receptacle but at times with a hyaline, homogeneous, gelatinous envelope. Cells with two apical cilia of unequal length, one or two golden-brown chromatophores, an eyespot and contractile vacuoles.

Uroglenopsis is the only representative in the local flora.

\section{UROGLENOPSIS Lemmermann 1899.}

Colonies free-swimming, with the cells embedded in a single layer at the periphery of a copious, hyaline, homogeneous, gelatinous matrix of spherical to broadly ellipsoid shape. Arrangement of cells radial or somewhat irregular. Cells spherical to narrowly ellipsoid; with two cilia of unequal length; two vacuoles at the anterior end; one or two laminate to disciform, parietal, golden-brown chromatophores; and with or without an eyespot.

Reproduction by vegetative cell division.

Uroglenopsis americana (Calkins) Lemmermann. Pl. 13, Figs. 1-4.

Forschungsbr. a. d. Biol. Stat. zu Plön 7: 107. 1899; Kryptogamenfl. d. Mark Brandenburg 3, Algen 1: 449, 444, figs. 1-3, 4-6. 1908.

Uroglena americana Calkins, Ann. Rept. Mass. State. Bd. of Health 23: 655, pl. 4, figs. 1-4. 1892; Moore, Bot. Gaz. 23; 105, pl. 10, figs. 1-11. 1897.

Colonies free-swimming, generally spherical. Cells ellipsoid, with one basal or lateral, parietal, disciform to laminate chromatophore. Eyespot single. Cilia of unequal length, with the longer 2-3 times the length of the cell, the shorter $1 / 3^{-1 / 2}$ the length of the cell. (Euplanktont).

Cells 3-7 $\mu$ broad, 5-10 $\mu$ long. Colonies up to $500 \mu$ in diam.

Beasley (cc), Bettine (ss), Browns (ss), Camp (ss), Carson (rrr), Diamond (rr), Eagle (sss), Fowler (cc), Howey (rr), Lac la Belle (ss), Long (3) (ss), Long (4) ( $r r)$, Lower Nemahbin (rr), Lynx (rr), Mendota (ss), Mill (ss), Mud (4) (cc), Nancy (rr), Oconomowoc (ss), Okauchee (rrr), Otter (ss), Paddock (s), Pewaukee (rr), Rainbow (1) (ss), Round (4) (rr), Taylor (ss), Wildcat (ss), Wolf (rr), Youngs (cc). 


\section{Family DINOBRYONACEAE.}

Cells solitary or in colonies, free-floating or sessile. Always attached to the base of a conical to vase-like, colored or hyaline, smooth or sculptured receptacle. Cells with one or two laminate chromatophores, contractile vacuoles, an eyespot, and two cilia of unequal length.

\section{KEY TO THE GENERA.}

Receptacles homogeneous, without growth rings.............. Dirobryov Receptacles with successive growth rings...........................

\section{DINOBRYON Ehrenberg 1835.}

Cells free-floating, sessile, or epiphytic; solitary or in colonies; attached to the bottom of conical, campanulate, or cylindrical receptacles with open apices and pointed bases. Colonial species arbuscular, each receptacle with the pointed ends of $1-4$ other receptacles in its mouth. Development of branching indefinite. Protoplast spindle-shaped, conical, or ovoid; attached by a stalk to the base of the receptacle. Anterior end of protoplast with two cilia of unequal length that project beyond the open end of the receptacle. Cells with one or two laminate, elongate, parietal, golden-brown chromatophores; several apical, lateral, or basal contractile vacuoles; and one apical eyespot. Assimilation product generally leucosin.

Reproduction by longitudinal division of cell contents to form ovoid daughter cells that migrate to the mouth of the old receptacle or leave it entirely before developing new receptacles. Akinetes known.

The specific limits of colonial plankton species of this genus are very poorly defined and it is almost impossible to draw a sharp line of demarcation between the various species. I have indicated as species the centers around which the variations seem to occur.

KEY TO THE SPECIES.

Cells solitary.

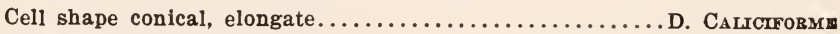

Cells broadly spindle-shaped.................... Tabellabiae Cells in colonies.

Branching of cells markedly divergent............... Divkekgens

Branching of cells not sharply divergent.

Cells elongate conical.

Sides of receptacles straight................ Stritatum

Sides of receptacles undulate................ B. Bararicus

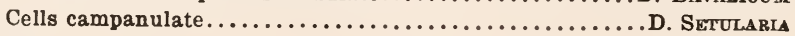


Dinobryon Caliciforme Bachmann. Pl. 13, Figs. 5-6.

Arch. f. Hydrob. u. Planktonkde. 3: 82, fig. XI's 1908.

Cells solitary; epiphytic upon the gelatinous envelope of various colonial Myxophyceae. Receptacles elongate conical, with a sharply pointed base. Protoplast the same shape as the lower two-thirds of receptacle. Chromatophores two, laminate, parietal, and golden-brown in color. Eyespot single. Cilia not as long as the cell. (Euplanktont).

Receptacles 5-6 $\mu$ broad at apex, 30-40 $\mu$ long.

Embedded in or on gelatinous envelope of Coelosphaerium Naegelianum and Microcystis aeruginosa.

Browns (sss).

Dinobryon tabellariae (Lemmermann) Pascher. Pl. 13, Figs. 7-9. Süsswasserfl. Deutschl., österr. u. d. Schw. 2, Flagellatae 2: 66, figs. 105a-105b 1913.

Dinobryon utriculus var. tabellariae Lemmermann, Arkiv för Botanik 2, No. 2: 119, pl. 1, fig. 19.1904.

Cells solitary; epiphytic upon filaments of Tabellaria. Receptacle broadly spindle-shaped, with the base produced into a short stipe. Protoplast attached to side of lower portion of receptacle, ovoid in shape and with the usual contents of the genus. (Euplanktont).

Receptacles $7-10 \mu$ broad at center, 4-5 at apex; 18-22 $\mu$ long.

Crawling Stone (r), Long (3) (rr), Sand (4) (s).

\section{Dinobryon bavaricum Imhof. Pl. 13, Fig. 10.}

Zool. Anz. 13: 484. 1890; Lemmermann, Bot. Not. 1903: 78, pl. 3, figs. 3-4. 1903.

Cells in free-floating compact colonies. Receptacles of individual cells elongate-conical. Base of receptacle very much produced with sides almost parallel; expanded portion of receptacle with undulate sides. Seasonal variation pronounced, the receptacles being much longer during the summer. (Euplanktont).

Receptacles $6.5-8.5 \mu$ broad; 45-100 $\mu$ long.

George (ss), Harris (rr), Marl (ss), Oconomowoc (ss), Speese (ss), Tied Canoe (ss), White Sand (s). 


\section{Dinobryon stipitatum Stein. Pl. 13, Fig. 11.}

Der Organismus der Infusionstiere 3: pl. 12, fig. 5. 1878; Pascher, D. Süsswasserfl. Deutschl. Österr. u. d. Schw. 2, Flagellatae 2: 73, fig. 118. 1913.

Cells always in narrow, fairly dense, free-floating colonies. Receptacles of individual cells elongate-conical, with bases produced into stipes with nearly parallel sides. Sides of receptacle not undulate. Individual receptacles of colony not divergent from one another. Seasonal variation chiefly in elougation of apical cells of colony. (Facultative Planktont).

Receptacles 6-8 $\mu$ broad; 56-96 $\mu$ long.

Marl (ss), Oconomowoc (cc), Round (4) (sss), South Turtle (rr).

\section{Dinobryon sociale Ehrenberg. Pl. 13, Fig. 12.}

Abh. d. k. Ak. d. Wiss. Berlin 1833: 279. 1835; Die Infusionsthierchen 125, pl. 8, fig. 9. 1839; Pascher, Süsswasserfl. Deutschl. Österr. u. d. Schw. 2, Flagellatae 2: 73, figs. 116-117. 1913.

Cells in free-floating colonies. Individual receptacles somewhat divergent from one another and producing a fairly loose colony. Receptacles conical, sometimes slightly constricted below the open mouth, with bases gradually tapering to a sharp point that is not extended to form a process. (Facultative planktont).

Receptacles $7-8 \mu$ broad, 30-70 $\mu$ long.

Beasley (ss), Green (1) (ss), Green (2) (cc), Mill (c), North Turtle (rr), Oconomowoc (cc), Silver (2) (s), Trout (rr).

Dinobryon setularia Ehrenberg. Pl. 13, Fig. 13; Pl. 14, Fig. 1. Abh. d. k. Ak. d. Wiss. Berlin 1833: 280. 1835; Die Infusionsthierchen 124, pl. 8, fig. 8. 1838.

Cells in free-floating, densely branching colonies. Receptacles cylindrical-campanulate, with the convex bases tapering abruptly to a sharp point. Cells with shorter and broader receptacles than the other species. Seasonal variation not so pronounced as in other species. (Facultative Planktont).

Receptacles 10-14 $\mu$ broad, 30-44 $\mu$ long.

Devils (1) (ccc), Kawaguesaga (ss), Long (4) (ss), Lost (ss), Lower Nemahbin (ss), Rock (ss), Round (3) (ss), Winnebago (rr). 


\section{Dinobryon divergens Imhof. Pl. 14, Fig. 2.}

Jahresbr. d. Naturf. Ges. Graubündens N. F. 30: 134. 1887.

Dinobryon cylindricum var. divergens (Imhof) Lemmermann, Ber. d. D. Bot. Ges. 18: 517, pl. 19, figs. 15-20. 1300.

Cells in free-floating densely or openly branched colonies. Receptacles with conical bases and the upper portion cylindrical or with slightly flaring mouths. The axis of the upper portion of receptacle forming an angle of 45-90 degrees with that of the basal portion. Sides of receptacle sometimes undulate. Seasonal variation confined to denseuess of branching in colony rather than changes in receptacle shape. (Facultative Planktont).

Receptacles $7-8 \mu$ broad, $35-50 \mu$ long (20-27 $\mu$ in upper portion and 15-20 in basal portion).

Beasley (s), Boulder (cc), Browns (cc), Center (ss), Devils (1) (ss), Elizabeth (cc), George (r), Green (2) (rr), Hill (cc), Lac la Belle (ss), Lnng (2) (rr), Marl (ss), Mary (cc), Meta (r), Mill (cc), Mud (1) (ss), Nagawicka (cc), North Turtle (ss), Oconomowoc (cc), Otter (ss), Rock (ss), Round (4) (rrr), Silver (2) (cc), Speese (cc), Tamarack (ss), Taylor (ss), Tied Canoe (ss).

\section{HYALOBRYON Lauterborn 1896.}

Cells solitary or in branching colonies, free-floating or epiphytic. Receptacle shape and cell contents as in Dinobryon but with the wall of the receptacle containing a number of successive growth rings instead of homogeneous. Wall of receptacle more delicate than Dinobryon.

\section{Hyalobryon mucicola (Lemmermann) Pascher. Pl. 14, Figs. 3-4.}

D. Süsswasserfl. Deutschl., österr. u. d. Sch.w. 2, Flagellatae 2: 81, fig. 131. 1913.

Hyalobryon Lauterbornei var. mucicola Lemmermann, Ber. d. D. bot. Ges. 10: 340. 1901; Bachmann, Arch. f. Hydrob. u. Planktonkde. 3: 81, figs. $\mathrm{XI}^{10}-$ $\mathrm{XI}^{17} .1908$.

Cells solitary, epiphytic upon gelatinous envelope of colonial Myxophyceae, Chlorophyceae and Phaeophyceae. Receptacle delicate, upper portion cylindrical and with a flaring mouth, lower portion conical and with a short stipe. Growth rings of receptacle numerous. Protoplast ovoid, attached to base of receptacle, with two golden-brown chromatophores, two cilia of unequal length and an eyespot. (Euplanktont).

Receptacles 4-6 $\mu$ broad, 25-45 $\mu$ long; stipe 4-12 $\mu$ long.

Crawling Stone (r), Lac du Flambeau (sss), Long (3) (c), Mud (2) (rr), Round (1) (rr). 


\section{Division HYDRURINEAE.}

Cells free-floating or sessile, usually in palmella-like colonies and motile only at the time of reproduction; rarely solitary, generally in gelatinous colonies of microscopic to macroscopic size that have a definite to indefinite shape. Colony capable of growth in all parts or with growing region restricted to apex. Gelatinous sheath of cells hyaline, homogeneous or lamellated. Cells ovoid to spherical, with one or two golden-brown parietal chromatophores and with or without a definite wall.

Reproduction by pyramidate, spherical, or ovoid zoospores with one or two cilia.

The members of this division are the connection between the normally motile and the highly differentiated sessile Phaeophyceae.

\section{Order PHAEOCAPSALES.}

Cells generally organized into free-floating, spherical, ellipsoid, or elongate colonies. Growth of colony taking place in all parts and not restricted to the apical region. Cells variously shaped and with one or two golden-brown chromatophores.

Reproduction, aside from vegetative cell division, by the formation of spherical to ovoid zoospores.

The order contains the single family of the Phaeocapsaceae and only one member of the family, Phaeococcus, is found in the local flora.

\section{PHAEOCOCCUS Borzi 1892.}

Cells in spherical, ovoid, or irregularly shaped free-floating colonies enclosed by a copious, hyaline, homogeneous or slightly lamellated, gelatinous envelope. Cells ellipsoid to sub-spherical or spherical. Cell number a multiple of two in young colonies, indefinite in older colonies. Cells containing one or more golden-brown chromatophores, sometimes with a red pigment spot.

Reproduction by vegetative cell division or direct metamorphosis of cell contents into biciliate ovoid to pyriform zoospores.

\section{Phaeococcus planctonicus W. \& G. S. West. Pl. 14, Fig. 5.} Trans. Roy. Soc. Edinb. 41: 496, pl. 6, figs. 15-16. 1905.

Cells spherical to sub-spherical, generally distributed in small clumps within a copious, hyaline, homogeneous or radially fibrillar, gelatinous envelope. Number of cells in colony generally 16-64. Cells contain- 
ing 1-2 parietal, disciform to bell-shaped, golden-brown chromatophores with smooth or irregular margins. (Euplanktont).

Cells 7.2-9.6 $\mu$ in diam.; colonies 50-250 $\mu$ in diam.

Carson (ss), Clear Crooked (c), Crawling Stone (rr), Devils (1) (ss), Hillman (rr), Jennie (r), Mary (s), Mendota (sss), Pokegama (1) (rr), Sand (4) (rr), Shell (ss), Silver (2) (s), White Sand (rr).

\section{Division RHIZOCHRYSIDINAE.}

Algae that are known in the rhizopodial stage only, although the power to form a motile phase is presumed to be present. Cells solitary or in small colonies, always free-floating. Cells with rhizopodial processes and with or without a differentiated periplast. Cells with 1-2 golden-brown chromatophores, and with or without numerous vacuoles.

Reproduction by vegetative cell division.

This is an entirely artificial group where rhizopodial forms are placed pending further elucidation of their life histories. Since the group contains such doubtful forms no attempt has been made to differentiate the orders and families.

KEY TO THE GENERA.

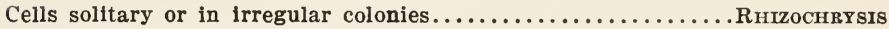
Cells joined in a linear series to form colonies............. Chrysidastrum

\section{RHIZOCHRYSIS Pascher 1913.}

Cells free-floating, solitary or in colonies that are naked or enclosed by a gelatinous sheath. Cells without a differentiation of the. periplast but with few or numerous, delicate, pseudopodial processes. Cells with one or two golden-brown chromatophores and numerous vacuoles, of small size when united in colonies.

Rhizochrysis limnetica sp. nov. Pl. 14, Fig. 6.

Cells solitary, free-floating, without a differentiation of the periplast but with numerous spicule-like processes extending in all directions. Cells approximately spherical, with one golden-brown chromatophore and numerous vacuoles. (Euplanktont).

Diam. cells (without processes) $35-45 \mu$.

Beasley (sss), Birch Island (rr), Crawling Stone (rr), Deer (rr), Diamond (rrr), Half Moon (rr), Horse (rr), Kitten (sss), Lac du Flambeau (r), Long (3) (sss), Marl (rrr), Nemahbin (ss), Oconomowoe (rr), Okauchee (rrr), 
Otter (rrr), Pokegama (2) (r), Rainbow (1) (r), Round (3) (rr), Sand (4) (sss), Taylor (r), Upper Nashotah (r), Wildcat (sss).

This species is quite unlike other members of the genus since the processes are much more delicate and the cells larger.

\section{CHRYSIDASTRUM Lauterborn 1913.}

Cells joined to one another by pseudopodial processes and arranged to form free-floating linear colonies of $2-16$ cells that are not enclosed by a gelatinous envelope. Cells spherical, with the periplast undifferentiated but extending into several long, delicate, pseudopodia-like processes. Chromatophore single, central, and laminate to band-shaped.

Reproduction unknown.

\section{Chrysidastrum catenatum Lauterborn. Pl. 14, Figs. 7-8.}

in Pascher, D. Süsswasserfl. Deutschl., österr. u. d. Schw. 2, Flagellatae 2: 91, fig. 144.1913.

Specific characters the same as those of the genus. (Euplanktont).

Diam. cells (without processes) 12-15 $\mu$; (with processes) $45-60 \mu$.

Kitten (rr), Mud (2) (rr), Wildcat (rrr).

The cell shape is quite like that of Chrysamoeba but the definite organization into a linear colony and the single laminate chromatophore are points of difference. The alga should also be compared with Rhizochrysis planctonica Pascher. 


\section{Class HETEROKONTEAE.}

Cells microscopic or macroscopic; free-floating, sessile, or epiphytic. Cell shape spherical, ovoid, pyriform, cylindrical or irregular. Cells solitary, in colonies of regular to irregular shape, or united to form simple filaments. Colonies or individual cells with or without a gelatinous envelope. Chromatophores one to many, parietal, generally disciform, rarely laminate, yellowish-green in color and without a pyrenoid. Assimilation product oil, never starch. Cells uninucleate or multinucleate.

Asexual reproduction by vegetative cell division and a formation of zoospores. Zoospores ovoid to pyriform, with two cilia of unequal length and generally more than one yellowish-green chromatophore.

Sexual reproduction, insofar as known, isogamous, by zoogametes that are similar in structure to the zoospores.

The various genera of the Heterokontae were formerly scattered throughout the different families of the Chlorophyceae. The distinguishing characteristics of this class are the yellowish-green chromatophores without pyrenoids, with oil not starch the assimilation product; and zoospores with two cilia of unequal length. There are three orders in the class and representatives of all three are found in Wisconsin lakes.

KEY TO THE ORDERS.

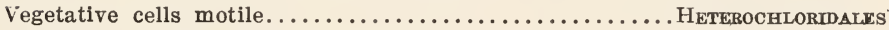
Vegetative cells immobile.

Cells solitary or in colonies, never in filaments..........HETERococcales

Cells united to form simple filaments............... HeterotrichaLes

\section{Order HETEROCHLORIDALES.}

Cells solitary, free-swimming, ovoid to pyriform in shape. Motile phase dominant, rarely metamorphosing over into an amoeboid or palmella phase. Cells with two cilia of unequal length, one or more chromatophores of a yellowish-green color and without an eyespot. Assimilation product leucosin or fat, never starch.

Asexual reproduction by vegetative division of cells.

Sexual reproduction unknown.

The order has but one family, the Chloramoebaceae, whose characters ale those of the order. 


\section{CHLOROCHROMONAS Lewis 1913.}

Cells solitary, generally free-swimming, very rarely amoeboid, sometimes attached to substratum by a posterior pseudopodia-like structure. Cell shape pyriform to sub-ovoid, with an oblique depression at the anterior end. Cilia two, at the anterior end of the cell and of unequal length. Chromatophores two, yellowish-green in color, oblong with rounded ends in front view, somewhat flattened in side view. Cells with a single anterior vacuole, one nucleus, and without an eyespot. Nutrition holophytic or saprophytic.

Reproduction by longitudinal fission when in the motile phase.

Chlorochromonas minuta Lewis. Pl. 15, Figs. 1-3.

Arch. f. Protistenkunde 32: 254, pl. 12, figs. 1-24. 1913.

Characters as described above. (Euplanktont).

Cells 4.5-9.5 (av. 6.3) $\mu$ long, with an average breadth of $4.7 \mu$. Average length of longer cilium $12.5 \mu$, of the shorter $2.9 \mu$.

Mendota.

This organism was first found by Lewis in a dish containing sections of basswood (Titia americana) that had been standing for some time in a dish of tap water, which is drawn directly from Lake Mendota. I have never noted the alga in plankton collections but have no doubt but that a continued search will demonstrate its presence in Lake Mendota. During the past winter (1917-18) the alga appeared in an infusion of fern leaves which had been standing for some time in tap water. This shows that the original source of the alga was the water with which the sections were moistened and not the Tilia.

\section{Order HETEROCOCCALES.}

Cells spherical, ovoid, saccate, or elongate cylindrical; solitary or in colonies of definite or indefinite shape; free-floating or sessile. Cells of colonies embedded in a hyaline, gelatinous envelope or a tough elastic membrane. Chromatophores one to many, yellowish-green to nearly grass-green in color and with oil not starch the assimilation product.

Asexual reproduction by vegetative cell division and a formation of zoospores with cilia of unequal length.

Sexual reproduction by a fusion of zoogametes that are similar in structure to the zoospores is known in certain genera. 
KEY TO THE FAMILIES.

Cells epiphytic. . Chlobosaccaceae

Cells freefloating.

Length of cells several times the diameter. . Ophiocytiaceas

Length of cells less than twice the diameter.

Cells irregularly distributed throughout an ovold gelatinous envelope.................... СНLововотRYDACEAE Cells arranged about a common center within an irregular gelatinous envelope...............BOTBYococCACEAE

\section{Family CHLOROSACCACEAE.}

Cells epiphytic, solitary, gregarious, or embedded in an amorphous gelatinous matrix. Chromatophores one to several, parietal, of a yellowish-green color, with oil not starch the assimilation product.

Asexual reproduction by a formation of zoospores that presumably have two cilia of unequal length.

Sexual reproduction by the fusion of isogamous zoogametes.

\section{PERONIELLA Gobi 1887.}

Cells epiphytic upon other algae, solitary or gregarious. Shape of mature cells globular to ovoid, of young cells pyriform to ovoid. Cells attached to substratum by a delicate hyaline stipe that is usually somewhat longer than the cell. Chromatophores one to two, pale yellowishgreen, without pyrenoids or starch and with oil as the assimilation product.

Asexual reproduction by the division of cell contents into 2-4-8 uniciliate (?) zoospores that are liberated by a lateral rupture of mother cell wall. Zoospores swarming a short time and then coming to rest upon substratum and developing into vegetative cells.

\section{Peroniella Planctonica G. M. Smith. Pl. 15, Fig. 4.} Bull. Torr. Bot. Cl. 43: 476, pl. 25, fig. 15.1916.

Cells broadly ovoid to pyriform, with a long, delicate, hyaline stipe that is without a disc or other enlargement at the base. Chromatophores usually single, rarely two, pale yellowish-green, without pyrenoids or starch. (Euplanktont).

Cells (without stipe) $6-9.5 \mu$ long; (with stipe) $15-18 \mu$. Stipe 8-10 $\mu$ long, $1.2 \mu$ broad.

In gelatinous envelope of Sphaerozosma filaments.

Devils (1) (rr). 


\section{Family CHLOROBOTRYDACEAE.}

Cells solitary or in free-floating colonies enclosed by a copious, homogeneous, gelatinous envelope. Colony generally with a small number of cells and with cell number a multiple of two. Cells spherical, ovoid, angular, or cylindrical; with a firm cell wall that is sometimes impregnated with a slight trace of silica; and with one to many parietal, disciform, yellowish-green chromatophores without pyrenoids.

Asexual reproduction by vegetative cell division or a formation of zoospores with two cilia of unequal length.

\section{CHLOROBOTRYS Bohlin 1901.}

Cells rarely solitary, generally in colonies of $2-4-8-16$ or more embedded in a copious, homogeneous, hyaline, gelatinous envelope. Cells spherical to broadly ovoid, with a heavy wall that sometimes contains a small amount of silica. A conspicuous red pigment spot present in cells at times.

Reproduction by vegetative division of cells in three directions.

\section{KEY TO THE SPECIES.}

Cells ovoid, with few chromatophores.................. LIMNETICUs Cells spherical, with numerous chromatophores............. REGULARIs

Chlorobotrys regularis (W. West) Bohlin. Pl. 15, Fig. 10. Bih. kgl. Sv. Vet.-Ak. Handl. 27, Afd. 3, No. 4: 34. 1901; W. \& G. S. West, Jour. of Bot. 41: 78, pl. 447, figs. 7-10. 1903.

Chlorococcum regulare W. West, Jour. Roy. Micr. Soc. 1892: 737, pl. 10, fig. 55.1892.

Cells spherical to subspherical; rarely solitary, generally in colonies of 2-4-8-16 enclosed by a copious, hyaline, homogeneous, gelatinous envelope. Cell wall thick, sometimes containing a trace of silica. Chromatophores yellowish-green, disciform, parietal, 6-30 in each cell. Cells at times containing a single conspicuous red pigment spot. (Tychoplanktont).

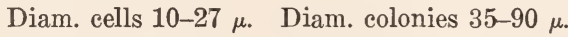

North Turtle (rrr).

Chlorobotrys limneticus G. M. Smith. Pl. 15, Fig. 9.

Trans. Wis. Acad. Sci., Arts, \& Lett. 19': 653, pl. 14, fig. 10. 1918.

Cells ovoid, irregularly distributed within a homogeneous, hyaline, gelatinous envelope. $10-30$ cells in a colony. Chromatophores $3-4$, 
pale yellowish-green, disciform, parietal, and without pyrenoids. (Euplanktont).

Cells 5-6 $\mu$ broad, 6-8 $\mu$ long. Diam. colonies 40-200 $\mu$.

Camp (rr).

\section{Family BOTRYOCOCCACEAE.}

Cells always in free-floating colonies of definite or indefinite shape. Number of cells in colony generally indefinite, few or many. Colony enclosed by an envelope that may be hyaline or colored, gelatinous or leathery. Cells usually ovoid, rarely spherical; with 1-2 parietal, laminate to disciform, yellowish-green to nearly grass-green chromatophores without pyrenoids and with oil as the assimilation product.

Asexual reproduction by vegetative cell division. Zoospore formation or sexual reproduction unknown.

\section{BOTRYOCOCCUS Kützing 1849.}

Cells in free-floating colonies of indefinite shape. Cells closely apposed to one another and enclosed by a gelatinous or tough membrane that is sometimes wrinkled and folded. Colonies generally with cells in several aggregates that are connected by broad or delicate strands of the colonial integument. Cell shape spherical, ovoid, or euneate. Groups of cells arranged in a single layer around a commion center, or irregular in arrangement. Chromatophore single, parietal, laminate to disciform, yellowish-green to nearly grass-green in color and without a pyrenoid.

Reproduction by vegetative division of cells.

\section{KEY TO THE SPECIES.}

Cells held together by a thin gelatinous envelope............. Sudericus Cells held together by an irregular tough membrane.

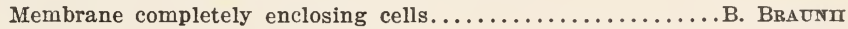

Membrane covering base only of cells........... Protuberans var. Mrnor

\section{Botryococcus sudeticus Lemmermann. Pl. 15, Fig. 8.}

Forschungsbr. a. d. Biol. Stat. zu Plön. 4: 111, figs. 6-7. 1896.

Botryococcus Braunii G. S. West non Kützing, Brit. Freshw. Algae 237, figs. 106A-106B. 1904; G. M. Smith, Trans. Wis. Acad. Sci., Arts, \& Lett. 18 ${ }^{2}$ : 545 1916.

Colonies free-floating; spherical or irregular; with cells held in botryoidal clusters by a hyaline gelatinous envelope and frequently joined 10 one another by broad or narrow strands of the gelatinous envelope. Cells spherical to subspherical, 16-32 or more in each botryoidal group, 
and arranged around a common center. Chromatophore single, cupshaped to disciform, without a pyrenoid. (Euplanktont).

Diam. cells 6-13 $\mu$.

Clear (rr), Waubesa (rrr).

This is the B. Braunii Ktz. of the preliminary list, the identification being based upon G. S. West's description of B. Braunii in his British Freshwater Algae. Dr. West has since informed me that the Ineffigiata neglecta of that work is $B$. Braunii Ktz. and the B. Braunii described therein is $B$. sudeticus Lemm.

\section{Botryococcus Brauni Kützing. Pl. 15, Fig. 5.}

Spectes algarum 892. 1849; Fresenius, Abh. Senckenb. Naturf. Ges. 2: 239, pl. 11, figs. 27-33. 1858.

Ineffigiata neglecta W. \& G. S. West, Jour. Roy. Micr. Soc. 1897: $503 . \quad 1897$; Jour. of Bot. 41: 80, pl. 447, figs. 1-6. 1903.

Cells joined in small free-floating colonies of irregular shape that are without a conspicuous gelatinous envelope but completely enclosed by a tough, elastic, hyaline to orange colored membrane that is produced into irregular wrinkles, folds, and spines. Colonies frequently united to form compound colonies by long delicate projections of the colonial envelope. Cells ovoid or ellipsoid in shape and forming a single layer around a central cavity. Chromatophore single, cup-shaped to laminate, yellowish-green to nearly grass-green in color, without a pyrenoid. Assimilation product a reddish oil that may color the whole colony a brick red. (Facultative planktont).

Cells 3.5-5.5 $\mu$ broad, 5.7-10.5 $\mu$ long. Simple colonies up to $100 \mu$ in diam.; compound colonies up to $1.5 \mathrm{~mm}$.

Balsam (rr), Bear (3) (rr), Bear Trap (rrr), Beaver (2) (rr), Beaverdam (ss), Birch Island (rrr), Birch (2) (rr), Boulder (rrr), Browns (sss), Camp (rrr), Carson (r), Center (r), Chain (rrr), Chetac (rr), Clam (rrr), Clare (r), Cochrane (rrr), Crawling Stone (rr), Crooked (sss), Deer (rr), Delavan (rrr), Des Moines (rr), Devils (1) (r), Devils (2) (r), Devils (3) (rrr), East (rr), Eltzabeth (rr), Green (1) (rr), Green (2) (rrr), Grindstone ( $r$ ), High ( $r r$ ), Horse (rrr), Horseshoe (1) (rr), Island (rr), Jennie (rr), Jones (rrr), Kawaguesaga (rrr), Kegonsa ( $r$ ), Kimball (rrr), Kitten (rrr), Lac Court Orellles (sss), Lac du Flambeau (rrr), Little Bass (1) (rrr), Little Butternut (rrr), Little Crooked (rrr), Little Doctor (rr), Little Rice (1) (rr), Long (1) (rrr), Lower Nashotah (r), Lynx (rr), Mary (sss), Mendota (ss), Mercer (rrr), Mill (rrr), Monona (sss), Mud (3) (rrr), Mud Hen (sss), Nancy (r), Nicaboyne (rrr), No Mans (rr), Paddock (r), Palmer (rrr), Pardee (sss), Pike (rrr), Pokegama (1) (rrr), Pokegama (2) (rrr), Poor Farm (rrr), Reserve (rr), Rice (1) ( $r r)$, Round (2) (rrr), St. Croix (rrr), Sand (1) (r), Sand (2) (rr), Sand (3) (rr), Sand (4) (rrr), Shell (rr), Silver (2) (r), Sishebogema (rr), South Turtle (rr), Spirtt (rrr), Tled Canoe (rrr), Travts (rrr), Upper Nashotah (sss), Wapagossett (rr), Waubesa (r), White Ash (rrr), Whitefish (rrr), Wildeat (rrr), Winnebago (rrr), Wolf (rrr). 
Botryococcus Protruberans var. Minor G. M. Smith. Pl. 15, Figs. 6-7. Trans. Wis. Acad. Sci., Arts, \& Lett. 19': 652, pl. 14, figs. 6-7. 1918.

Cells in colonies of 4-8-16 or more held together by a tough gelatinous membrane. Colonies frequently joined to one another by long hyaline strands of the colonial envelope. Cells ovoid to cuneate-ovoid, with their bases embedded in the colonial envelope and their apices not enclosed by the envelope. Cells arranged in a single layer around a central cavity. Chromatophores single, yellowish-green, laminate, occupying the median portion of the cell. (Euplanktont).

Cells 8-9.5 $\mu$ long, 5-6.5 $\mu$ broad at the widest part.

Diamond (rrr), George (aa), Hillman (rr), Lindy (rr), Oak (ss), Pardeo (rr), Sanford (rr), South Crab (s).

This species is distinguished from the foregoing by the smaller number of cells in the colony and the projection of the apex of the cells through the colonial integument.

\section{Family OPHIOCYTIACEAE.}

Cells sessile or free-floating, solitary or colonial. Length of cells generally several times the breadth. Cells straight, curved, sigmoid, or spiral; with or without terminal spines. Chromatophores yellowishgreen; annular, parietal and few in number; or disciform, parietal and numerous; without pyrenoids and with oil as the assimilation product.

Asexual reproduction by division of cell contents to form 4-16 aplanospores or 2-8 biciliate zoospores with cilia of unequal length.

Sexual reproduction unknown.

\section{OPHIOCYTIUM Nägeli 1849.}

Cells free-floating or epiphytic, solitary or colonial; straight, arcuate, sigmoid, or spiral elongate cylinders with rounded or capitate ends that may be apiculate or attenuated into a single spine. Chromatophores pale yellowish-green, H-shaped in optical cross section, without pyrenoids and with oil as the assimilation product. Cells coenocytic. Cell wall consisting of a homogeneous cap at one end and with the remaining portion of the wall composed of a number of laminate layers.

Asexual reproduction by division of cell contents to form 4-16 aplanospores or 2-8 biciliate zoospores with cilia of unequal length. 
KEY TO THE SPECIES.

Poles of cells without spines. . O. Pabvulum Poles of cells with spines. O. Capitatum

Ophiocttium parvulum (Perty) A. Braun. Pl. 15, Fig. 11. Alg. unicell. 55. 1855; Lemmermann, Hedwigia 38: 33, pl. 4, figs. 30-33. 1899.

Cells cylindrical, several times as long as broad; straight, arcuate, or spiral; poles rounded and without spines. Chromatophores several, H-shaped in cross section, pale yellowish-green. Oil droplets rarely present. (Tychoplanktont).

Cells 3-9 $\mu$ broad.

Fishtrap (rrr).

Ophocytium capitatum Wolle. Pl. 15, Figs. 12-13.

Freshw. Algae of U. S. 176, pl. 158, figs. 3-7. 1887.

Cells solitary; arcuate, sigmoid, or spiral cylinders with poles rounded and the same size as or slightly larger than the median portion of the cell. Length of cell 5-10 times the breadth. Poles of cells with a single short, straight, or slightly curved spine. (Tychoplanktont).

Cells 5-10 $\mu$ broad, up to $85 \mu$ long. Spines $5-7 \mu$ long.

Tied Canoe (rrr).

var. LONGispinum (Möbius) Lemmermann. Pl. 15, Figs. 14-16. Hedwigia 38: 32, pl. 4, figs. 21-25. 1899.

Cells cylindrical; straight, arcuate, or spirally twisted, with a single long spine at each pole that is nearly as long as the cell. (Euplanktont).

Diam. cells 4.5-6 $\mu$. Length of spines $16-50 \mu$.

George (rr), Loon (rr).

\section{Order HETEROTRICHALES.}

Cells in simple, unbranched filaments; with or without a gelatinous envelope. Cell wall firm, fairly thick, lamellated in structure and breaking down into $\mathrm{H}$-shaped pieces at the time of reproduction. Chromatophores few to several, yellowish-green, disciform, and parietal. Cells usually uninucleate. Assimilation product oil, not starch.

Asexual reproduction by the formation of aplanospores or by zoospores with two cilia of unequal length. 
Sexual reproduction by the fusion of isogamous zoogametes.

There is but one family in the order, the Tribonemaceae, whose characters are the same as those of the order.

TRIBONEMA Derbes and Solier 1856.

Cells in simple unbranched filaments destitute of an enveloping gelatinous sheath. Cells cylindrical or barrel-shaped, with flattened end walls. Cell wall frequently of considerable thickness and laminate in structure. Chromatophores two to several, yellowish-green, disciform, parietal, without starch and with oil as the assimilation product.

Asexual reproduction by aplanospores and biciliate zoospores that have cilia of unequal length. The cell wall pulling apart and breaking dnwn into $\mathrm{H}$-shaped pieces at the time of reproduction.

Sexual reproduction by the fusion of isogamous zoogametes.

Tribonema minus (Wille) Hazen. Pl. 15, Figs. 17-18.

Mem. Torr. Bot. Cl. 11: 185, pl. 25, figs. 7-8. 1902.

Filaments generally forming a floceose yellowish to greenish mass. Cells cylindrical or slightly swollen in the median portion, generally $2-4$, rarely 6 , times as long as broad. Chromatophores 2-4, yellowishgreen, disciform, parietal, generally in pairs. (Facultative planktont).

Cells 5-6 $\mu$ broad, 10-35 $\mu$ long.

Green (1) (rrr), Mendota (s).

Members of this genus are frequently found in ditches but seldom in lakes. During the past season $T$. minus has appeared in considerable quantity in the plankton of Lake Mendota, although previous to this time the alga has not been found in the plankton. A similar sudden appearance of $T$. bombycina forma depauperata Wille, a form closely related to $T$. minus, has been noted in the plankton of Danish lakes by Wesenberg-Lund (Studier over de danske soers Plankton p. 100. Kjobenhavn, 1904). 


\section{Class CHLOROPHYCEAE.}

Cells with the coloring matter restricted to definite bodies that are grass-green in color (chloroplasts). Cells free-floating, sessile, epiphytic, epizootic, or endophytic; solitary, in microscopic to macroscopic colonies of definite or indefinite shape that are naked or enclosed by a hyaline to colored, homogeneous or lamellated, firm or gelatinous envelope. Colonies with all of the cells morphologically alike or differentiated. Colonies growing in all directions; forming simple, laminated, or parenchymatous plates; or developing into simple or branched filaments. Cells motile throughout the whole life history, for a portion of it, or immobile at all times. Cells variously shaped; spherical, hemispherical, ovoid, ellipsoid, spindle-shaped, acicular, reniform, angular, irregular, cylindrical, conical, simple to branching tubular, or constricted to form two symmetrical halves of various shapes. Cells containing one or more disciform, laminate, cup-shaped, astral, ribbon-like, or reticulate chloroplasts that are parietal, axial, or central in position and have one or more centers for the synthesizing of starch (pyrenoids). Assimilation product oil in a few cases. Cells uninucleate or multinucleate (coenocytic); containing a central vacuole, numerous small vacuoles, or without vacuoles. Contractile vacuoles chiefly confined to the motile genera.

Asexual reproduction by vegetative cell division, aplanospores, zoospores, or akinetes.

Sexual reproduction by isogamous or heterogamous zoogametes, isogamous aplanogametes, or heterogamous motile antherozoids and immobile oospheres. Zygotes germinating immediately, or after a period of rest; with a direct or an indirect germination into the plant body.

\section{KEY TO THE DIVISIONS}

Sexual or asexual reproductive bodies with $2-4$ cilia of equal length.. IsokonTaz Sexual or asexual reproduction by non-ciliate reproductive bodies....Akontar

\section{Division ISOKONTAE.}

Cells solitary or in colonies and showing the same great range of variation in shape, organization of the colony, interior structure, and method of reproduction noted in the description of the class.

Included in this division is the important plankton family of the Autosporaceae where no motile phase of reproduction is known. The 
close phylogenetic connection between the Autosporaceae and the other members of the Protococcales is, however, perfectly evident.

\section{KEY TO THE ORDERS.}

Cilla normally present throughout the whole life cycle.......... Volvocalrs Cilia present at time of reproduction only.

Cells in simple or branched filaments.

Cells uninucleate, with a single laminate chloroplast.... UlotrichaLfa

Cells multinucleate, with one or more chloroplasts..Siphorocladiares Cells solitary or in simple colonies, generally of microscopic

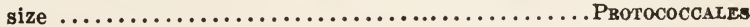

\section{Order VOLVOCALES.}

Cells normally ciliate and motile during the vegetative phases of the life cycle. Solitary or organized into colonies of definite form that generally contain a definite number of cells. Protoplasts rarely naked, usually with a differentiated outer cellulose covering that may be partially gelatinized. Shape of protoplast spherical, ovoid, disciform, pyramidate, or irregularly radiate. Cells with a single eup-shaped to irregular chloroplast, with or without pyrenoids; with 2-4 cilia at the anterior end; generally with a disciform to bacilliform eyespot, two to several contractile vacuoles, and one nucleus. Palmella stages frequently arising in the unicellular members.

Asexual reproduction by division of cell contents into 2-16 zoospores ; or a development of special, or all cells of the colony into autocolonies.

Sexual reproduction by isogamous zoogametes; heterogamous zoogametes; or small motile antherozoids and large immobile oospheres.

Many hold with G. S. West (Algae 151, 1916) "that it is very doubtful if the Volvocineae have sufficient claims to be removed from the Protococcales and elevated to a group of equal rank (the "Volvocales')". There is a very close relationship between the "palmella" stage of various unicellular Volvocales and the family Palmellaceae of the Protococcales. This represents to me, however, a close phylogenetic relationship between the two and not a justification for uniting in the same order forms with mobile vegetative cells and those which are immobile.

\section{KEY TO THE FAMILIES.}

2 cllia at the anterior end of cells.

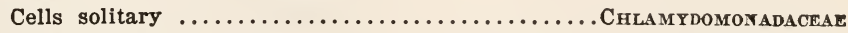

Cells in definite coenobla ........................ VolvocaceAe

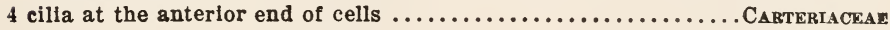




\section{Family CHLAMYDOMONADACEAE.}

Cells normally solitary and motile during the vegetative phases of the life history. Spherical, ovoid, cylindrical, sub-acicular, compressed, or quadrately projected. Chloroplast cup-shaped to laminate, lateral or posterior in position, with or without pyrenoids. Cells uninucleate, with or without an eyespot, with two cilia of equal length that generally have two contractile vacuoles at their base. Cells at times becoming immobile and developing into amorphous colonies enclosed by a wide gelatinous envelope.

Asexual reproduction by the division of cell contents to form 2-16 biciliate zoogametes.

Sexual reproduction by the fusion of isogamous zoogametes.

\section{CHLAMYDOMONAS Ehrenberg 1832.}

Cells normally solitary and motile; though capable of coming to rest, losing the cilia, developing a gelatinous envelope and dividing vegetatively to form colonies containing an indefinite number of cells. Cells spherical, fusiform, ovoid, pyriform, or ellipsoid ; with two cilia of equal length at the anterior end. Chloroplast typically cup-shaped, posterior, and with one pyrenoid. Cells uninucleate, generally with two contractile vacuoles at the base of the cilia; with or without an eyespot which, when present, lies in the anterior portion of the cell.

Asexual reproduction by division of cell contents to form 2-16 biciliate zoospores.

Sexual reproduction isogamous, by the division of cell contents into 8-64 zoogametes that fuse in pairs to form smooth-walled or sculptured zygotes.

Cells spherical.

KEY TO THE SPECIES.

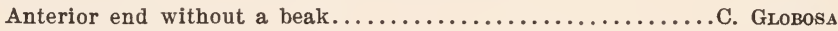

Anterior end with a pronounced beak................ EPIPHYTICA Cells ovoid.

Chloroplast cup-shaped and basal..................... SNown

Chloroplast laminate, lateral, or basal................ DrNoBryorı

Chlamydomonas globosa Snow. Pl. 16, Fig. 8.

Bull. U. S. Fish Comm. 22: 389, pl. 1, figs. III ${ }^{1}-I^{5}$. 1903.

Cells spherical or slightly ellipsoid, without an anterior beak. Chloroplast cup-shaped, occupying the greater portion of the cell, with one pyrenoid at the posterior end. Eyespot present, small, generally in the middle third of the cell. Cilia slightly longer than the cell and with a 
single contractile vacuole at their base. Palmella stages frequent and usually containing 4-8 cells. (Euplanktont).

Cells $5-10 \mu$ broad.

Crawling Stone (rr).

Chlamydomonas epiphytica sp. nov. Pl. 16, Figs. 11-13.

Cells spherical to pyriform, with a very pronounced anterior beak. Chloroplast cup-shaped, forming a thin layer next to the cell wall, with a single pyrenoid at the posterior end. Eyespot conspicuous, disciform, at the anterior end of the cell. Cilia more than twice as long as the cell. Cells frequently coming to rest in the gelatinous envelope of Microcystis colonies but not losing the eyespot and usually retaining the cilia. (Euplanktont).

Cells $7-8 \mu$ broad, 8-9 $\mu$ long; cilia 20-25 $\mu$ long.

Elizabeth (s), Mary (sss).

The alga is frequently found in the gelatinous envelope of Microcystis colonies and suggests an epiphytic Characium but the presence of cilia shows that it is a Chlamydomonas.

\section{Chlamydomonas Snowi Printz. Pl. 16, Figs. 9-10.}

Skr. Vidensk.-Selsk. 1 Kristiana, Mat.-Naturv. Kl. 1913²: No. 6: 18.1914.

Chlamydomonas communis Snow, Bull. U. S. Fish Comm. 22: 388, pl. 1, figs. $\mathrm{II}^{1}-\mathrm{II}^{2} .1903$.

Cells motile but frequently forming palmella stages containing a considerable number of cells. Cell shape ovoid to ellipsoid, with a very inconspicuous anterior beak. Chloroplast cup-shaped, massive in the posterior portion, with one pyrenoid at the center of the cell. Cilia slightly longer than the cell; eyespot inconspicuous, variable in position. (Facultative planktont).

Cells $6.5-8 \mu$ broad, 10-15 $\mu$ long.

Nancy ( $r r)$.

Chlamydomonas dinobryoni sp. nov. Pl. 16, Figs. 5-7.

Cells rarely free-swimming, generally in large numbers and filling the empty receptacles of Dinobryon colonies. Cells small, ovoid to pyriform in shape, without an anterior beak; with two short cilia at the anterior end. Chloroplast disciform to hemispherical, basal or lateral in position, containing a pyrenoid. Eyespot and contractile vacuoles not observed. (Euplanktont).

Cells $2-3 \mu$ broad, 3.5-5 $\mu$ long; cilia 6-8 $\mu$ long.

Lac du Flambeau (ss), Long (3) (s), Pokegama (2) (r). 
Many of the empty Dinobryon receptacles in these three connecting lakes were filled with a minute green organism. These had cilia, even when in the receptacle, and on the slightest crushing of the receptacle began swimming around outside of it. Since cilia are constantly present the alga is a Chlamydomonas and not one of the Palmellaceae collected at the time of reproduction.

\section{Family CARTERIACEAE.}

Cells normally motile and with four cilia of equal length at the anterior end. Solitary, or in coenobia containing a definite number of cells. Cell shape spherical, ovoid, ellipsoid, cardioid, pyriform, or lenticular. Cells enclosed by a definite wall, and with or without a cup-shaped to lenticular chloroplast that is with or without pyrenoids. Eyespot generally present, conspicuous, and at the anterior end of the cell. Cells frequently with contractile vacuoles at the base of the cilia. Palmella stages known in the solitary members of the family.

Asexual reproduction by the division of cell contents into 2-16 tetraciliate zoospores or into autocolonies.

Sexual reproduction isogamous, by a fusion of tetraciliate zoogametes.

\section{CARTERIA Diesing 1866.}

Cells solitary, generally motile throughout the vegetative phases of the life cycle. Spherical, ovoid, ellipsoid, or cardioid in shape; with four cilia of equal length at the anterior end. Cell contents consisting of a single cup-shaped chloroplast that contains a pyrenoid; one eyespot; and two contractile vacuoles at the base of the cilia. Palmella stages containing an indefinite number of cells are found at times.

Asexual reproduction by division of cell contents to form 2-8 tetraciliate zoospores.

Sexual reproduction by the division of cell contents to form 4-64 tetraciliate zoogametes that fuse in pairs to form zygotes with smooth or sculptured walls.

KEY TO THE SPECIES.

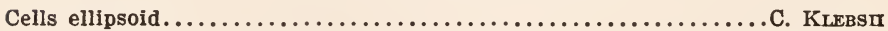

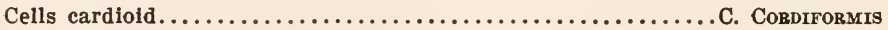

\section{Carteria Cordiformis (Carter) Diesing. Pl. 16, Fig. 1.}

Sitzbr. d. k. Ak. d. Wiss. Wien, Mat.-Naturw. Kl. 52' : 356. 1866; Dill, Jahrb. f. wiss. Bot. 28: 353, pl. 5, figs. 42-44. 1895.

Cells cardioid in shape with four cilia at the base of the apical depression. Chloroplast cup-shaped, fairly massive, with a single pyre- 
noid in the posterior region. Cells with two contractile vacuoles at the base of the cilia and with a disciform eyespot in the upper third of the cell. (Tychoplanktont).

Cells 9-16 $\mu$ broad, 12-20 $\mu$ long.

Crawling Stone (rrr).

Carteria Klebsir (Dangeard) Dill. Pl. 16, Figs. 2-4.

Jahrb. f. wiss. Bot. 28: 353. 1895; Printz, Skr. Vidensk.-Selsk. Kristiana, Mat.Naturv. Kl. 1913' : No. 6: 13.1914.

Pithiscus Klebsii Dangeard, Ann. Sci. Nat. 7 Sér. Bot. 7: 137, pl. 12, figs. 1-6. 1888.

Cells solitary, ellipsoid to ellipsoid-cylindrical, with a more or less prominent beak at the anterior end. Chloroplast cup-shaped, massive, with a large pyrenoid at the posterior end. Cells without an eye-spot and with two contractile vacuoles at the base of the cilia. Cilia about twice as long as the cells. Palmella stages containing many cells at times. (Tychoplanktont).

Cells 5-10 $\mu$ broad, 8-16 $\mu$ long.

Pokegama (1) ( $r$ ).

Family VOLVOCACEAE.

Cells always motile and in coenobia of definite shape that contain a definite or an indefinite number of cells. Colonies enclosed in a homogeneous, hyaline, gelatinous envelope. Cells of colony all alike or differentiated into vegetative and reproductive cells. Vegetative cells spherical, ellipsoid, pyriform or disciform; with or without connecting cytoplasmic processes; always biciliate. Chloroplasts generally cupshaped and containing one pyrenoid. Vegetative cells usually with an eyespot and two contractile vacuoles.

Asexual reproduction by the division of all or certain of the cells in the colony to form autocolonies.

Sexual reproduction by a division of all cells in the colony to form isogamous zoogametes or heterogamous zoogametes of slightly different size; or the formation of motile antherozoids from certain cells and large immobile oospheres from others. Zygotes with smooth or sculp. tured walls. 
KEY TO THE GENERA.

Colony with cells in a flat plate............................... Colony with cells forming a hollow sphere.

Cells mutually compressed. .PANDORINA Cells some distance from one another.

Asexual reproduction by division of all cells in colony......Eudorins Asexual reproduction by division of special cells.

At least half of cells capable of forming autocolonies... PLEOdoBina Only a few cells capable of forming autocolonies......... Volvox

\section{GONIUM Mueller 1773.}

Colonies of $4-8-16$ cells arranged in a flat quadrangular plate and embedded in a common gelatinous matrix or connected by broad gelatinous strands. Cells ovoid to pyriform, with a single cup-shaped chlorcplast containing one pyrenoid. Each cell with two cilia of equal length, contractile vacuoles at the base of the cilia, and an eyespot. Four- and eight-celled colonies with the cilia on the same side; sixteencelled colonies with the four central cells having their cilia on the same side and the twelve marginal cells with radially arranged cilia.

Asexual reproduction by simultaneous division of all cells in the colony to form autocolonies, or by a formation of $2-4$ zoospores in each cell.

Sexual reproduction isogamous, by a fusion of biciliate zoogametes.

Gonium pectorale Mueller. Pl. 16, Figs. 14-15.

Vermium terrestrium et fluviatilium etc. 1: 60. 1773; Migula, Bot. Cent. 44: 72, pl. 2, figs. 1-8. 1890; Harper, Trans. Am. Micr. Soc. 31: 65, pl. 5, figs. 1-19, 23. 1912 .

Colonies containing 4-8-16 cells. Usually with 16 cells arranged in two concentric series in a flat plate with truncate corners. Cells connected with one another by broad, hyaline, gelatinous processes and with open spaces between the processes; or with processes indistinct and the whole colony embedded in a homogeneous, gelatinous matrix. Outer ring with twelve cells whose long axes lie parallel to the plane of the coenobe. Inner ring of four cells with a large open space at the center and their long axes perpendicular to plane of the coenobe. Cells ovoid to pyriform, with two cilia at the anterior end; a posterior massive cup-shaped chloroplast; an anterior eyespot; and two contractile vacuoles at the base of the cilia. (Tychoplanktont).

Cells 7-11 $\mu$ broad, 10-25 $\mu$ long.

Beaverdam (rrr), Clam (rrr), Duck (rr), Fowler (rrr), Island (r), Ko gonsa (rrr), Long (1) (rrr), Mendota (rrr), Number One (rr), Pike (rrr), Poplar (rrr). 


\section{PANDORINA Bory 1824.}

Colonies always motile, spherical to subspherical, containing 4-8-1632 cells mutually compressed to form a hollow sphere with a small open space at the center. Colony enclosed by a fairly copious, firm, hyaline, homogeneous, gelatinous envelope. Cells pyriform to angular by mutual compression, with pointed ends toward the center of the colony; biciliate at the flattened distal end, the two cilia lying close together while passing through the colonial envelope and then becoming markedly divergent. Chloroplast single, massive, cup-shaped, with one pyrenoid at the base. Eyespot single, generally on distal face of the cell. Cells with a definite wall and two contractile vacuoles at the base of the cilia.

Asexual reproduction by simultaneous division of all cells of the colony to form autocolonies that are liberated by a gelatinization of the colonial envelope.

Sexual reproduction by a division of each cell of the colony into 16-32 zoogametes. Zoogametes showing indications of heterogamy in the slight difference in size and motility of the pairs that fuse to form the smooth walled zygote.

\section{Pandorina morum Bory. Pl. 16, Figs. 16-17.}

Encyc. meth. hist. nat. de Zoophytes 2: 600. 1824; G. S. West, Brit. Freshw. Algae 193, figs, $76 \mathrm{~A}-76 \mathrm{H}$. 1904.

Colonies generally 16-celled and as described above. (Facultative Planktont).

Cells 8-16 $\mu$ broad; colonies $20-45 \mu$ broad.

Bear Trap (rrr), Blake (rrr), Camp (rr), Center (cc), Chetac (rr), Chetek (ss), Deer (rrr), Duck (ss), East (rrr), Fowler (rr), Grindstone (s), Hillman (rr), Hooker (s), Kegonsa (sss), Lac Court Oreilles (ss), Lindy (rr), Little Bass (2) (rr), Little Butternut (rr), Little Rice (1) (r), Little Wood (rrr), Long (1) (rrr), Loveless (rr), Lower Nashotah (rr), Lower Nemahbin (rr), Lower Turtle (sss), Mendota (ss), Monona (s), Mud (1) (rrr), Nagawicka (ss), Nicaboyne (r), No Mans (rr), Number One (rr), Oconomowoc (rrr), Okauchee (rrr), Pokegama (3) (r), Prairie (r), Rice (1) (r), St. Croix (rr), Sishebogema (rr), South Turtle (sss), Upper Nashotah (rr), Upper Nemahbin (rr), Upper Turtle (rr), Waubesa (ss), Whitefish (rr), Winnebago (rr).

\section{EUDORINA Ehrenberg 1832.}

Colonies always motile, spherical or slightly elongate, of 16-32-64 cells lying some distance from one another and arranged to form a hollow sphere near the periphery of the homogeneous, hyaline, gelatinous envelope. Cells spherical, with or without a beak at the point of origin of the two cilia. Cilia parallel while passing through the 
colonial envelope and then widely divergent. Chloroplast single, cupshaped, filling practically the whole cell and generally with several pyrenoids. Cells with a firm wall, one or two anterior contractile vacuoles, and a single conspicuous eyespot near the base of the cilia.

Asexual reproduction by a simultaneous division of all cells to form autocolonies which are liberated by a rupture of the colonial envelope.

Sexual reproduction heterogamous, dioecious, with all cells of a colony developing into large immobile oospheres or plate-like masses of 32-64 fusiform antherozoids; or monoecious with four cells forming antherozoids and the remainder oospheres. Zygote smooth-walled.

\section{Eudorina Elegans Ehrenberg. Pl. 19, Fig. 1.}

Abh. d. kgl. Ak. d. Wiss. zu Berlin 1831: 78, pl. 2, figs. 10^-10D. 1832; G. S. West Brit. Freshw. Algae 194, figs. 77A-77F. 1904.

Colonies generally 32-celled and as described above. (Facultative planktont).

Cells $12-24 \mu$ in diam.; colonies 50-200 $\mu$ in diam.

Balsam (rrr), Bear (3) (ss), Bear Trap (r), Beaverdam (sss), Big Butternut (rr), Birch (2) (ss), Birch Island (rr), Boulder (cc), Bryer (rr), Camp (cc), Catherine (ss), Center (sss), Chetac (ss), Chetek (s), Clam (rr), Crawling Stone (rrr), Delavan (sss), Devils (1) (aa), Diamond (sss), Duck (ss), Dunham (ss), Dutchmans (rrr), Elizabeth (rr), Fish (sss), Fowler (rr), Granite (ss), Green (2) (rr), Grindstone (rrr), Hillman (rr), Hill (rrr), Hooker (rr), Horseshoe (1) (rr), Horseshoe (2) (rrr), Howey (rrr), Island (ss), Jennie (r), Kawaguesaga (rr), Kegonsa (ss), Lac Court Oreilles (rr), Lac la Belle (rr), Lake of the Woods ( $\$$ ), Lindy (rr), Little Butternut (rr), Little Wood (rrr), Long (3) (rrr), Loon (rr), Lower Nemahbin (rrr), Lower Turtle (r), Lynx (rr), Meronk (rrr), Middle McKenzie (rr), Nancy (rr), Nicaboyne (ss), No Mans (rr), North Turtle (ss), North Twin (rr), Number One (rr), Okauchee (rr), Paddock (cc), Pine (2) (rrr), Pike (r), Pokegama (2) (rr), Pokegama (3) (ss), Poplar (rr), Prairie (ss), Reserve (rr), Rainbow (rrr), Rice (1) (ss), Rooney (rr), Round (1) (r), Round (2) (rr), Round (3) (sss), Sand (1) (sss), Sand (4) (rr), Silver (2) (c), Sishebogema (ss), South Crab (rr), South Turtle (sss), Spirit (sss), Squirrel (ss), Tenderfoot (rrr), Travis (rrr), Vermilion (rr), Waubesa (sss), White Sand (rrr).

\section{PLEODORINA Shaw 1894.}

Colonies always motile; spherical to sub-spherical, with 32-128 cells lying some distance from one another just within the periphery of the homogeneous, hyaline, gelatinous, colonial envelope and not connected by cytoplasmic strands. Cells differentiated into those that are purely vegetative in character and those capable of dividing to form daughter colonies. All but four cells of the colony reproductive or about half reproductive and half vegetative. Cells spherical to ovoid in shape. Vegetative cells with a cup-shaped chloroplast containing one pyrenoid; 
2 large anterior eyespot; two cilia of equal length with two contractile vacuoles at their base. Reproductive cells at first like the vegetative cells, later with a more massive chloroplast that eventually contains several pyrenoids. The eyespot and cilia of reproductive cells disappearing when they are mature.

Asexual reproduction by a simultaneous division of all reproductive cells to form autocolonies.

Sexual reproduction (which has been observed in one species only) heterogamous, dioecious, by a division of all reproductive cells to form plates of 64-128 biciliate, fusiform antherozoids; or a development of reproductive cells into oospheres. Zygotes smooth-walled.

The validity of this genus has been questioned by many and the view put forward that the alga is but a stage in the life history of Eudorina. Grove (New Phytol. 14: 169-182. 1915) gives a full discussion of the literature of Pleodorina. Although Eudorina elegans is found in a large number of Wisconsin lakes, Pleodorina has been found in but three of them. If Pleodorina is a developmental stage of Eudorina, it is strange that the "Pleodorina" stage has not been observed with greater frequency. The young colonies look very much like those of Eudorina and it is probably on this account that the two have been confused.

Pleodorina Calffornica Shaw. Pl. 17, Figs. 1-3.

Bot. Gaz. 19: 279, pl. 27, figs. 1-9. 1894.

Colonies containing 64-128 cells. Cells usually spherical and about half vegetative and half reproductive. Reproductive cells becoming 4-5 times broader than the vegetative cells. (Facultative planktont).

Vegetative cells $6-14 \mu$ in diam.; reproductive cells $6-34 \mu$ in diam. Colonies $40-400 \mu$ in diam.

Clam (ss), Mud (1) (cc), Sand (1) (r).

VOLVOX L. 1758.

Colonies always motile, spherical to ovoid, containing a large number of cells arranged in a single layer just within the periphery of the homogeneous, hyaline, gelatinous, colonial envelope. Cells differentiated into those for vegetative purposes, asexual, and sexual reproduction. Vegetative cells close together or some distance from one another, with or without cytoplasmic connections of varying thickness. Cell shape spherical, ovoid, or disciform. Individual cells or groups of cells sometimes enclosed by their own gelatinous envelope. Cells with two cilia of equal length, 2-6 contractile vacuoles, one nucleus 
one eyespot, and a cup-shaped to disciform chloroplast that contains one pyrenoid. Number of cells in a colony varying from 200-22,000.

Asexual reproductive cells few in number (rarely more than 20) and forming autocolonies by repeated division, the young colonies migrating to the center of the coenobe at a certain stage in their development.

Sexual reproduction heterogamous, monoecious or dioecious, with a development of 6-400 cells into spherical oospheres and few or many of the cells into antheridia that contain 16-256 biciliate fusiform antherozoids. Zygote with a smooth or stellate wall.

\section{KEY TO THE SPECIES.}

Cells with cytoplasmic connections.

Cytoplasmic connections heavy...................... GLobato

Cytoplasmic connections delicate....................... Aureus Cells without cytoplasmic connections................... MonoNaE

\section{Volvox globator L. Pl. 18, Figs. 3-5.}

Systema natura, Ed. 10: 820. 1758; Cohn, Beitr. z. Biol. d. Pflanzen 1, Heft 3: 93, pl. 2, figs. 1-6. 1875 .

Colonies large, with many $(1,000-22,000)$ cells that are flattened and pentagonal to octagonal in surface view. Cells connected to one another by stout cytoplasmic strands. Chloroplast of cells single, flattened and angular, with one pyrenoid. Cells with 2-6 contractile vacuoles at the base of the two cilia and with an eyespot. Gelatinous sheaths of individual cells sharply defined and (in surface view) pentagonal to octagonal by mutual compression. Generally with 8 asexual reproductive cells giving rise to autocolonies. Colonies commonly monoecious, with 12-40 (generally $20-30$ ) oospheres enclosed by large gelatinous vesicles. Antherids a flat plate of 64-256 fusiform antherozoids with laterally attached cilia. Zygote verrucose, with conical warts. (Tychoplanktont).

Cells 2-7.5 (generally 3-5) $\mu$ in diam. Colonies 400-800 $\mu$ in diam.

Center (s), Hooker (rr), Kegonsa (rr), Monona (r), Soft (rrr), Waubesa (rrr).

\section{Volvox aureus Ehrenberg. Pl. 18, Fig. 2.}

Die Infusionsthierchen $71, p l .4$, fig. 2. 1838; Klein, Jarhb. f. wiss. Bot. 20: 138, pl. 12, figs. 26-33. 1889.

Colonies spherical, containing a comparatively small $(200-4,000)$ number of cells. Cells circular in surface view, connected with one another by very fine cytoplasmic strands. Individual gelatinous sheaths of cells confluent with the colonial envelope. Cells containing a spheri- 
cal chloroplast, one eyespot, and a pair of contractile vacuoles at the base of the two cilia. 4-14 asexual reproductive cells giving rise to autocolonies. Colonies generally dioecious, with 3-9 oospheres and about half of the cells developing into antherids that contain 16-32 fusiform antherozoids with two terminal cilia. Zygote smooth-walled. (Facultative Planktont).

Cells 5-9 $\mu$ in diam.; colonies 200-680 $\mu$ in diam.

Beaverdam (rrr), Camp (sss), Center (ss), Delavan (ss), Eagle (rr), Elizabeth (rrr), Fowler (rrr), Jennie (rrr), Kawaguesaga (rrr), Lac du Flambeau (rr), Lac la Belle (rr), Mill (rrr), Oconomowoc (rrr), Paddock (r), Pokegama (1) (rr), St. Croix (rrr), Silver (2) (rr).

Volvox mononae sp. nov. Pl. 18, Fig. 1.

Colonies spherical, containing a comparatively small (400-2500) number of cells. Cells spherical, not connected with one another by cytoplasmic processes. Individual sheaths of cells confluent with colonial envelope. Cells containing a single bell-shaped chloroplast with one pyrenoid, an eye spot, and two cilia whose length is $2-3$ times the diameter of the cell. 3-10 asexual colonies formed inside the coenokium and these daughter colonies in turn frequently containing young colonies. Asexual reproductive cells becoming much larger than vegetative cells before division commences. Colonies dioecious, with oogonia and antheridia in young daughter colonies only. 20-60 cells of a young colony formng typical Volvox antheridia that generally contain 64 antherozoids. Female colonies with 6-10 oospheres. Zygote smooth walled.

Vegetative cells $5-8 \mu$ in diam. Colonies $50-350 \mu$ in diam.

Monona (aaa).

\section{Order PROTOCOCCALES.}

Vegetative cells immobile; free-floating, sessile, or epiphytic; solitary or in colonies. Colonies amorphous and frequently embedded in a gelatinous envelope; or of definite shape and with or without a gelatienvelope. Colonies capable or incapable of increasing the number of their cells after they are formed. Cells variously shaped, generally with one chloroplast and pyrenoid.

Asexual reproduction by zoospores, fragmentation of the colony, autospores, or autocolonies. Resting akinetes known in some species.

Sexual reproduction by isogamous zoogametes known but not found in a majority of the genera. 


\section{KEY TO THE FAMILIES.}

Asexual reproduction by zoospores.

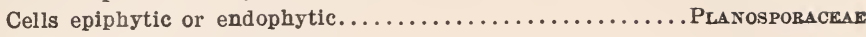
Cells or colonies free-floating.

Colonies capable of growth by cell division. .Palmellaceaz

Colonies incapable of growth by cell division........... HYDBodictYacEAE Asexual reproduction by autospores or division of cells.

Cells capable of vegetative division.

Solitary, in regular masses, or in strata.............. РвотососсасEAE

In colonies held together by remains of old cell walls.. DictYospHakriaceaE Cells incapable of division except to form autospores.........Autosporacear

\section{Family PALMELLACEAE.}

Cells spherical, ovoid, or reniform; rarely solitary, generally united to form colonies which are at times of macroscopic size. Colonies always embedded in a gelatinous matrix. Colonies capable of an increase in size by the vegetative division of the constituent cells. Chloroplasts generally single, cup-to disc-shaped and parietal; or star-shaped and central; with or without pyrenoids.

Reproduction by the fragmentation of the colony or by zoospores.

Sexual reproduction known in certain genera.

\section{KEY TO THE GENERA.}

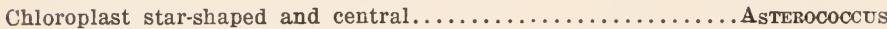
Chloroplast cup- to disc-shaped and parietal.

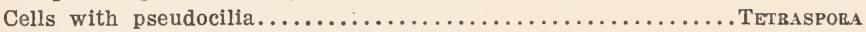

Cells without pseudocilia.

Gelatinous envelope of colony lamellated................ Giozocystis

Gelatinous envelope of colony homogeneous.

Cells spherical.

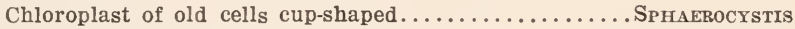

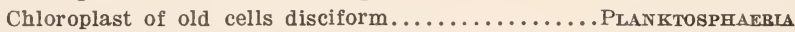

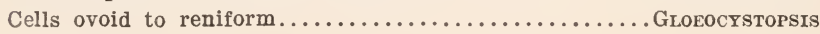

\section{GLOEOCYSTIS Nägeli 1849.}

Cells spherical; solitary or in small colonies of eight cells or less. Each cell and the whole colony surrounded by a hyaline, lamellated, gelatinous sheath. Chloroplast of young cells cup-shaped, parietal, and with one pyrenoid; generally diffuse and rich in starch in old cells.

Asexual reproduction by a fragmentation of the colony through the softening of the gelatinous envelope, or by zoospores. Akinetes known. 
Glokocystis gigas (Kützing) Lagerheim. Pl. 19, Fig. 2.

öfvers. kgl. Vet.-Ak. Förh. 40: No. 2: 63. 1883; G. S. West, Brit. Freshw. Algae 245: figs. $113 \mathrm{~F}-113 \mathrm{H}$. 1904.

Cells spherical; solitary or in families of 2-8; enclosed by a thick, distinctly lamellated, gelatinous envelope. Chloroplast of young cells cup-shaped, of older cells diffuse. (Tychoplanktont).

Cells 9-17 $\mu$ in diam.; colonies $45-95 \mu$ in diam.

Mendota (rr), Oconomowoc (rr).

\section{SPHAEROCYSTIS Chodat 1897.}

Colonies spherical with the cells in groups of 4-8-16-32 and disposed towards the periphery of a hyaline, homogeneous, gelatinous envelope and with the envelope surrounding each group of cells distinct or confluent with the colonial envelope. Colonies sometimes forming palmella stages where the cells are irregularly disposed. Cells spherical; chloroplast cup-shaped or filling the entire cell, with one pyrenoid.

Reproduction by the liberation of a group of cells through the softening of the colonial envelope. Zoospores of two sizes have been observer.

\section{Sphaerocystis Schroeteri Chodat. Pl. 19, Figs. 3-4.}

Bull. Herb. Boiss. 5: 119, pl. 9, figs. 1-12. 1897; G. S. West, Jour. Linn. Soc. Bot. 39: 76, figs. 9A-9F. 1909.

Characters the same as those of the genus. (Euplanktont).

Diam. cells 6-22 $\mu$; diam. colonies 50-500 $\mu$.

Balsam (rr), Bear (2) (ss), Bear Trap (sss), Beasley (rr), Big (sss), Big Butternut (rr), Birch (1) (rr), Birch (2) (ss), Birch Island (rr), Boulder (ss), Browns (rr), Camp (rr), Carson (rr), Catfish (rr), Center (rr), Chetac (ss), Chetek (cc), Clam (rrr), Clear Crooked (s), Crab (r), Cranberry (rr), Deer (rr), Devils (1) (sss), Eagle (rr), East (rr), Elizabeth (sss), Found (r) Fowler (rr), Green (1) (rr), Half Moon (rr), Hillman (rr), Hooker (rr), Kimball (rr), Kitten (rr), Lac Court Oreilles ( $r r)$, Lac du Flambeau (r), Lac la Belle (ss), Little Bass (1) (ss), Little Butternut (r), Little Doctor (rr), Little Wood (rr), Long (1) (ss), Long (2) (rr), Long (3) (rrr), Loveless ( $r r$ ), Lower Nashotah (rr), Lower Nemahbin (cc), Lower Turtle (r), Mary (ss), Mendota (r), Meta (cce), Mill (sss), Monona (r), Mud (1) (rr), Mudhen (sss), Nicaboyne (r), No Mans (rr), North Turtle (rr), North Twin (rr), Number One (cc), Oconomowoc (ss), Okauchee (ss), Old Taylors (rr), Pike (rr), Pine (2) (rr), Pine Tree (rr), Pokegama (1) (ss), Pokegama (3) (sss), Poplar (ss), Prairie (ss), Rainbow (rr), Rice (1) (ss), Rock (r), Round (1) (rrr), Round (2) (rr), Rudolph (rr), Sand (3) (rr), Sand (4) (rrr), Shell (ccc), Silver (2) (r), South Turtle (r), Tamarack (rr), Upper Nemahbin (rr), Upper Turtle (rr), Waubesa (rr), Winnebago (r). 
Lemmermann follows Wille in placing the alga as a synonym of Braun's old genus Gloeococcus but I prefer to follow G. S. West's practice and consider the two genera distinct. The ordinary vegetative condition is easily recognized but the rather rare palmella stage may be mistaken for one of the limnetic Tetraspora species.

\section{TETRASPORA Link 1809.}

Colonies macroscopic or microscopic; attached or free-floating; gelatinous; spherical, cylindrical, expanded, or variously lobed. Cells spherical, generally in groups of four towards the periphery of the homogeneous, hyaline, gelatinous colonial envelope. Sometimes irregularly distributed within the gelatinous colonial envelope. Chloroplast eupshaped, parietal; sometimes diffuse; with one pyrenoid. Each cell with two or four long, hyaline, gelatinous bristles (pseudocilia).

Asexual reproduction by the direct metamorphosis of vegetative cells into biciliate zoospores.

Sexual reproduction by a division of vegetative cells to form 4-8 bilciliate zoogametes that fuse in pairs.

\section{Tetraspora lacustris Lemmermann. Pl. 19, Figs. 5-6.}

Bot. Cent. 76: 152. 1898; Forschungsbr. a. d. Biol. Stat. zu Plön 7: 118, pl. 1, jig. 13. 1899.

Colonies microscopic; spherical, elongate, or irregular in shape; always free-floating. Cells spherical, generally in groups of four and with pseudocilia 6-8 times as long as the diameter of the cell. Chloroplast single, cup-shaped, and parietal; with or without pyrenoids. (Euplanktont).

Diam. cells 7-10 $\mu$; diam. colonies up to $300 \mu$.

Crawling Stone (sss), Fence (rrr), Long (3) (sss), Mud (2) (sss), Pike (rrr).

Small colonies frequently resemble palmella stages of Sphaerocystis Schroeteri but Tetraspora may be recognized by the pseudocilia. In case of doubt it is always advisable to stain with safranin to bring out the pseudocilia.

\section{GLOEOCYSTOPSIS G. M. Smith 1916.}

Cells elongate-cylindrical, with rounded ends and more or less curved. Cells aggregated in fours or eights within a homogeneous gelatinous sheath. Colonies spherical to ovoid and composed of an indefinite number of these aggregates. Colony not enclosed by a gelatinous sheath. 
Chloroplast of young cells single, laminate, parietal, with one pyrenoid; diffuse in old cells.

Reproduction, aside from vegetative cell division, unknown.

Gloeocystopsis limneticus G. M. Smith. Pl. 20, Figs. 1-2. Bull. Torr. Bot. Cl. 43: 475, pl. 24, fig. 12. 1916.

Cells 4-6 $\mu$ broad, 10-15 $\mu$ long. Cell aggregates 25-30 $\mu$ in diam.; colonies up to $125 \mu$ in diam. (Euplanktont).

Bear Trap (rr), Beaverdam (rrr), Catfish (rr), Harris (rrr), Little Bass (2) (rrr).

A species that combines the general external morphological characteristics of Gloeocystis and the cell shape of Nephrocytium.

\section{PLANKTOSPHAERIA G. M. Smith 1918.}

Cells spherical, embedded in a copious, homogeneous, hyaline, gelatinous envelope. At first solitary, later irregularly distributed within the gelatinous envelope. Nature cells with several parietal, polygonal, flattened chloroplasts each of which contains a single pyrenoid.

Reproduction by liberation of daughter colonies through the breaking down of the gelatinous colonial envelope.

Planktosphaeria gelatinosa G. M. Smith. Pl. 20, Figs. 3-6. Trans. Wis. Acad. Sci., Arts, \& Lett. 19' : 627, pl. 10, figs. 8-11. 1918.

Specific characters as described above. (Euplanktont).

Diam. cells 4.5-25 $\mu$; colonies up to $150 \mu$ in diam.

Browns (rr), Mendota (r).

The general appearance of the colony suggests Sphaerocystis $S$ chroeteri but $P$. gelatinosa differs in the numerous parietal chloroplasts of each cell.

\section{ASTEROCOCCUS Scherffel 1908.}

Cells spherical or sub-spherical, solitary or in colonies, with a wide, homogeneous or lamellated, gelatinous envelope. Chloroplast single, central, star-shaped, the astral radiations ending in a dise at the cell wall. Pyrenoid single, at the center of the chloroplast. Certain species with two peripheral vacuoles and an eyespot.

Asexual reproduction by vegetative cell division and biciliate subspherical zoospores.

Sexual reproduction unknown. 
Asterococcus limneticus G. M. Smith. Pl. 20, Figs. 7-10. Trans. Wis. Acad. Sci., Arts, \& Lett. 19 : 627, pl. 10, figs. 3-6. 1918.

Colonies spherical, rarely ovoid, of 4-8-16 spherical cells widely separated from one another and lying within a hyaline, homogeneous, gelatinous matrix. Chloroplast single, star-shaped, with 4 or 8 (rarely 16) rays coming from a central mass and ending in a dise at the cell wall. Pyrenoid single, at the center of the chloroplast. (Euplanktont).

Diam. cells 7.5-35 $\mu$; colonies up to $125 \mu$ in diam.

Chain (r), Clam (sss), Crooked (rrr), Deer (rrr), Des Moines (rr), Dummy (ss), Fish (sss), Half Moon (rr), Hillman (rrr), Horseshoe (1) (ss), Horseshoe (2) (rr), Howey (rr), Lac Court Oreilles (ss), Lake of the Woods (rr), Long (1) (r), Nancy (r), North Twin (rrr), Owen (cc), Reserve (r), Rooney (rr), Sand (1) (r), Sand (3) (r), Shell (cc), Whitefish (sss), Wild Goose (rrr).

The shape and cellular arrangement in colonies of this species is quite similar to that of Sphaerocystis, but a sharp distinction exists in its star-shaped chloroplast, a type of chloroplast that is very uncommon. The alga is widely distributed in the lakes of northwestern Wisconsin.

\section{Family DICTYOSPHAERIACEAE.}

Cells in spherical or ovoid colonies, the number in young colonies a multiple of two, in older colonies indefinite. Colonies with or without a gelatinous envelope. Cells held together in fours or eights by the persistence of the old mother cell wall in repeatedly branching fourarmed thongs or irregular threads. Chloroplast single; cup-shaped, or filling the entire cell; with one pyrenoid.

Reproduction by the division of cells into autospores which remain attached to mother colony until accidentally broken away.

KEY TO THE GENERA.

Colony enciosed in a gelatinous sheath................ Dictrosphaerium Colony not enclosed in a gelatinous sheath.

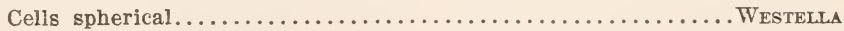

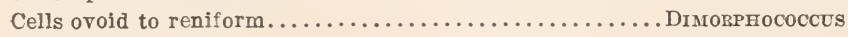

\section{DICTYOSPHAERIUM Nägeli 1849.}

Cells spherical, ovoid, or reniform, connected with one another by cruciately or dichotomously branching threads. Colony enclosed by a hyaline, homogeneous, gelatinous envelope that is spherical or ovoid in shape. Chloroplast single, parietal, cup-shaped, with one pyrenoid. 
Reproduction by the division of the cell into 2 or 4 daughter cells which remain connected to the colony by the old mother cell wall that divides into 2 or 4 parts to form the branching thread system connecting the cells. Zoospores reported but their existence is very doubtful. Resting akinetes known.

KEY TO THE SPECIES.

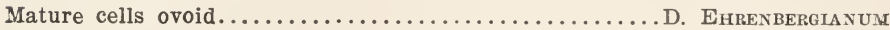
Mature cells spherical.

D. PULCHRLLUN

Dictyosphaerium Ehrenbergianum Nägeli. Pl. 20, Figs. 11-12. Gatt. einz. Algen, 73, pl. 2, figs. Ea-E'. 1849.

Colonies spherical to ovoid, rarely containing more than 30 cells. Cells ovoid to ellipsoid when mature. Chloroplasts 1-2, parietal, laminate, generally with a single pyrenoid. (Facultative Planktont).

Cells 4-7 $\mu$ broad; 6-10 $\mu$ long.

Clear (rr), Kegonsa (rrr), Mendota (rr).

Dictyosphaerium pulchellum Wood. Pl. 20, Fig. 13; Pl. 21, Fig. 1. Smithsonian cont. to knowl. 19, No. 241: 84, pl. 10, fig. 4. 1872.

Colonies spherical to broadly ovoid, of 4-8-16-32 or many cells lying uear the periphery of the hyaline, homogeneous, gelatinous envelope. Cells spherical when mature, spherical to ovoid when young; generally in fours at the ends of a repeatedly branching system of threads. Chloroplast single, parietal, cup-shaped, with one pyrenoid. (Facultative planktont).

Diam. cells 3-10 $\mu$.

Amicoy (ss), Balsam (rrr), Bear (1) (ss), Bear (2) (r), Bettine (s), Big Butternut (r), Birch (1) (r), Birch (2) (rrr), Blake (ss), Bone (r), Boulder (rrr), Canteen (rr), Carson (sss), Catfish (r), Catherine (rrr), Center (r), Chain (rr), Chetac (ss), Chetek (ss), Crab (s), Cranberry (rr), Crawling Stone (rrr), Deer (rr), Diamond (rr), Duck (cc), Dummy (sss), Eagle (rr), Elizabeth (rrr), Fishtrap (rr), Granite (ss), Grassy (rr), Grindstone (rr), Half Moon (rr), High (rr), Hillman (ss), Horse (rr), Horseshoe (1) (rrr), Horseshoe (2) (ss), Howey (rr), Jag (rr), Kawaguesaga (rr), Kegonsa (r), Kitten (rrr), Lac Court Oreilles (ss), Lac du Flambeau (rr), Lindy (rr), Little Bass (1) (rr), Little Bass (2) (rr), Little Butternut (rr), Little Crooked (rrr), Little Rice (2) (sss), Little Wood (sss), Long (1) (rrr), Long (3) (rrr), Loon (r), Loveless (rr), Lower Turtle (r), Lynx (rrr), Mendota (ss), Mercer (rrr), Middle McKenzie (rrr), Monona (ss), Mud (2) (rr), Mudhen (rr), Nagawicka (rrr), Nancy (r), Nicaboyne (rr), North Turtle (r), Oconomowoc (r), Okauchee (rr), Old Taylors (rr), Owen (rrr), Palmer (rr), Pewaukee (rr), Pine Tree (sss), Pokegama (1) (r), Pokegama (3) (c), Poor 
Farm (rrr), Prairie (c), Reserve (rr), Rice (ss), Rock (rr), Rooney (rr), Rose (sss), Rozen (rr), St. Croix (rrr), Sand (3) (rrr), Shell (cc), Sishebogema (rr), South Turtle (rr), Spirit (r), Tamarack (sss), Tenderfoot (rr), Tied Canoe (rrr), Travis (rr), Upper Nashotah (sss), Upper Nemahbin (rr), Vermilion (r), Wapagossett (rrr), Waubesa (ss), White Ash (sss), Whitefish (rr), White Sand (rr), Wild Goose (s), Winnebago (sss).

\section{DIMORPHOCOCCUS A. Braun 1855.}

Cells in groups of four and held in an irregular free-floating colony by the branching remains of the old mother cell wall. Colony not enclosed by a gelatinous envelope. Each aggregate of four cells lying in oue plane with two cells ovoid to cylindrical with rounded ends, and two cells reniform to cardioid. Chloroplast of young cells single, parietal, laminate, with one pyrenoid; chloroplast of old cells occupying the entire cell.

Reproduction by the division of any cell into four daughter cells which remain attached to the colony by the threadlike remains of old cell wall until accidentally broken away.

\section{Dimorphococcus lunatus A. Braun. Pl. 21, Fig. 5.}

Alg. Unicell. 44. 1855; Rabenhorst, Fl. Eur. Algarum 3: 36, figs. a-c (p. 6). 1868; G. S. West, Brit. Freshw. Algae 221, figs. 93А-93в. 1904.

Cells of each group of four alternately arranged (in vertical view) the central cells cylindrical with rounded ends, the terminal cells reniform to cardioid. (Facultative planktont).

Cells 4-15 $\mu$ broad, 9-25 $\mu$ long. Colonies up to $150 \mu$ in diam.

Bear (2) (rr), Bear (3) (rr), Beaverdam (rrr), Blue Gill (rrr), Catfish (rr), Des Moines (rrr), Devils (2) (rr), Horseshoe (1) (rr), Horseshoe (2) (rrr), Kegonsa (rrr), Lindy (rr), Minocqua (rrr), Mud (1) (rr), Pike (rr), Pine (1) (rr), Pine Tree (rrr), St. Croix (rrr), Shell (rrr).

\section{WESTELLA de Wildeman 1897.}

Cells small, spherical to sub-spherical, grouped in fours (rarely eights) in irregular, free-floating colonies containing 30-100 cells; the colony being held together by the non-gelatinizing remains of the old rother cell walls. Colonies without a gelatinous envelope. Chloropiast cup-shaped and parietal, or entirely filling the cell, with or without a pyrenoid.

Reproduction by the division of any cell to form 4-8 autospores that remain connected with the mother colony until accidentally broken away. 
KEY TO THE SPECIES.

Groups with cells quadrate or pyramidate................. Botryordes Groups with cells in a linear series....................... Lineabis

Westerla botryomes (W. West) de Wildeman. Pl. 21, Fig. 4. Bull. Herb. Boiss. 5: 532.1897.

Tetracoccus botryoides W. West, Jour. Roy. Micr. Soc. 1892: 735, pl. 10 , figs. 43-48. 1892.

Colonies irregularly shaped, without a gelatinous envelope, generally containing 40-80 cells. Cells spherical, pyramidately or quadrately arranged in groups of four (rarely eight). Chloroplast single, cupshaped or entirely filling the cell; with or without a pyrenoid. (Facultative Planktont).

Diam. cells 3-9 $\mu$.

Blake (rrr), Fishtrap (rr), Hillman (rrr), Horse (rrr), Horseshoe (1) (rr), Jag (r), Little Bass (2) (rr), Little Butternut (rrr), Little Crooked (rr), Mendota (rrr), Mill (rrr), Nancy (rr), Pine Tree (rr), Round (3) (rr), Sishebogema (rr).

var. MAJOR G. M. Smith.

Trans. Wis. Acad. Sci., Arts, \& Lett. 19' ${ }^{1}$ : 628. 1918.

Cells larger than the typical form, otherwise the same.

Diam. cells 8-13 $\mu$.

Whitefish (rr).

Westella linearis sp. nov. Pl. 21, Figs. 2-3.

Colonies of irregular shape, rarely containing more than 40 cells. Cells spherical, always in groups of four and arranged in a linear series. Remains of old mother cell walls that hold the colony together very inconspicuous. Colony without a gelatinous envelope. Chloroplast single, parietal, without a pyrenoid. (Euplanktont ?).

Diam. cells $3-6 \mu$.

Pine Tree (rr).

In the arrangement of the cells this species is quite unlike the other members of the genus but since the cells are in groups of four that are held together by the remains of old mother cell walls it seems better to place it in this genus than in Crucigenia. 


\section{Family PROTOCOCCACEAE.}

Cells solitary and spherical; or in colonies containing an indefinite number of cells that are spherical and mutually compressed or in very short irregular filaments. Cell wall delicate to heavy, smooth or variously sculptured. Chloroplast single, parietal and disciform, with or without pyrenoids. Cells capable of vegetative division.

Reproduction, aside from vegetative division of cells, by zoospores or aplanospores.

KEY TO THE GENERA.

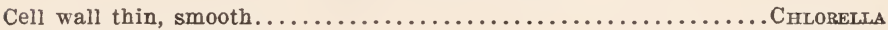

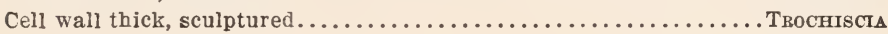

\section{CHLORELLA Beyerinck 1890.}

Cells small, spherical; solitary or in small colonies of indefinite shape. Chloroplast disciform to cup-shaped, with or without a pyrenoid.

Reproduction by the division of cell contents into 2-4-8 daughter cells. Resting akinetes known.

Chlorella vulgaris Beyerinck. Pl. 22, Fig. 1.

Bot. Ztg. 48: 758, pl. 7, figs. 2a-2b. 1890.

Cells spherical, generally solitary. Chloroplast parietal, cup-shaped, with or without a pyrenoid. Cell wall smooth and delicate. (Facultative Planktont).

Diam. cells $5-10 \mu$.

Mendota (rr).

C. vulgaris is a minute alga and one that is easily overlooked. The record of its occurrence in Lake Mendota is based upon its isolation by pure culture methods from a plankton catch. It is very probable that it is present in other lakes but has been overlooked.

\section{TROCHISCIA. Kütznig 1845.}

Cells spherical to sub-spherical, solitary or in small clumps. Cell wall fairly heavy, areolate or ornamented with spines, denticulations, ridges, or other projections. Cells generally containing several parietal disciform chloroplasts each with a pyrenoid.

Reproduction by vegetative cell division or the formation of 4-16 aplanospores that are liberated by the dissolution of the old mother cell wall. 
Trochiscia Reticularis (Reinsch) Hansgirg. Pl. 22, Fig. 2.

Hedwigia 27: 129.1888.

Acanthococcus reticularis Reinsch, Ber. d. D. bot. Ges. 4: 242, pl. 12, figs. 24a-24b. 1886.

Cells generally solitary, spherical. Cell wall fairly thick and covered with linear ridges that intersect to form 50-70 polygons on the surface of the cell. (Tychoplanktont).

Diam. cells 24-32 $\mu$.

Wildcat (rrr).

\section{Family AUTOSPORACEAE.}

Cells solitary or in colonies that are generally of a definite shape and without a gelatinous envelope. Cells variously shaped; with a single chloroplast and pyrenoid as a rule. Cells incapable of vegetative division to form two similar daughter cells.

Reproduction by division of cell contents into 2-4-8-16-32-64 cells which assume the shape of the mother cell before their liberation (autospores). In the colonial species the autospores from any one cell are nrganized to form the new colony (autocolony) before their liberation. Niotile asexual reproductive bodies or sexual reproduction unknown.

KEY TO THE SUBFAMILIES.

Cells solitary.

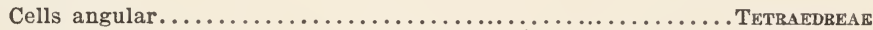

Cells not angular.

Ornamented with long spines or setae...............Mrcractinteae (p. p.)

Not ornamented with spines or setae.

Length of cells several times the diameter.......... SELENASTrEAE (p.p.)

Length of cells not more than twice the diameter....Oocrsteat (p.p.)

Cells in colonies.

Ornamented with long setae or spines.

Coenobe capable of growth in three directions.......MrCRACTINIEAE (p.p.)

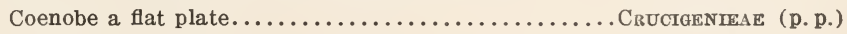

Not ornamented with setae or spines.

Number of cells in coenobe always a multiple of two.

Coenobe flat...................................

Coenobe spherical or cells radiating from a common

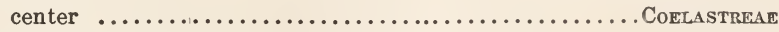

Number of cells not a multiple of two in every case.

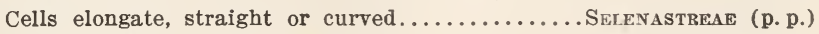

Cells spherical, ovoid, or reniform................... Oocrsteae (p. p.) 


\section{Subfamily OOCYSTEAE.}

Cells spherical, ovoid, or reniform; solitary or in temporary colonies. Daughter cells retained within old mother cell wall for some time after their formation. Walls generally thick and cells with one to many chloroplasts.

\section{KEY TO THE GENERA.}

Cells within old mother cell wall separated by a dark gelatinous

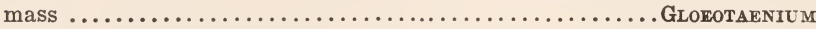

Cells within old mother ceil wall not separated by a dark gelatinous mass.

Cells ovoid to elliptic, never curved.........................

Cells ovoid to reniform, frequently curved.............. NEPHROCYTIUM

\section{OOCYSTIS Nägeli 1845 .}

Cells ovoid, ellipsoid, or cylindrical with rounded to somewhat pointed ends, generally symmetrical but never curved. Cell wall smooth, withcut spines, frequently with nodular thickenings at the poles. Chloroplasts one to many; parietal, disciform, stellate, or reticulate; with or without pyrenoids. Cells solitary or in temporary colonies of 2-4-8-16 or more enclosed by the partially gelatinized and greatly swollen old mother cell wall.

Reproduction by a formation of 2-4-8-16 autospores that remain within the old cell wall for some time. Three to four cell generations sometimes enclosed by the same wall. Tetraedron-like resting spores with granulate walls have been observed.

The genus differs from others in the expanded cell wall that encloses the cells in temporary colonies. Printz (Nyt. Mag. f. Naturvidensk. 1913, p. 165) has recently monographed the genus and cleared up many points by collecting the published descriptions of species; but there is great need of a series of cultural studies to determine the range of variation within the so-called "species" that are recognized at the present time.

KEY TO THE SPECIES.

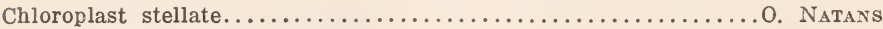
Chloroplast disciform to laminate.

Cells with polar nodules.

Sides of cells concave. O. Panduriformis

Sides of cells convex.

4 or more chloroplasts in each cell.

Cells with $40-60$ chloroplasts. . O. Eremosphaeria 
Cells with 6-25 chloroplasts.

Polar nodules conspicuous, $12-25$ chloroplasts......... Solitaria

Polar nodules not prominent, $4-10$ chloroplasts......... CRassa 1-2 (rarely 4) chloroplasts in each cell.

Cells elliptic, length $1 \frac{1}{2}$ times breadth.............. Lacustris

Cells oblong-cylindrical, length $2-3$ times breadth...... O. Submarina Cells without polar nodules.

Poles of cells rounded.

Length of cells less than $12 \mu \ldots \ldots \ldots \ldots \ldots \ldots \ldots$. Pusmis

Length of cells more than $12 \mu$.

1-4 chloroplasts in each cell................... Borger

$8-10$ chloroplasts in each cell................ ELLiptica

Poles of cells pointed.

Old cell wall enclosing colonies rounded............. PArva

Old cell wall enclosing colony sharply pointed..O. GLoeocystiformis

\section{Oocystis PUSILLA Hansgirg. Pl. 22, Fig. 3.}

Sitzbr. d. k. böhm. Ges. d. Wiss. in Prag, Jahrgang 1890: 9. 1890; Printz, Nyt. Mag. f. Naturvidensk. 51: 181, pl. 4, figs. 31-32. 1913.

Cells cylindrical, poles rounded and without nodules. Chloroplasts 2-3, parietal, laminate, without pyrenoids. Temporary colonies containing $2-4-8$ cells. (Tychoplanktont).

Diam. cells 4.5-6.5 $\mu$; length 8-12 $\mu$.

Tied Canoe (rr).

\section{Oocystis Borgei Snow. Pl. 22, Fig. 4.}

Bull. U. S. Fish Comm. 22: 379, pl. 2, figs. VII'-VII'5 1903.

Cells broadly elliptic, length $1 \frac{1}{2}$ times the breadth; poles rounded but without nodules. Chloroplasts 1-4, parietal, laminate, each containing a single pyrenoid. Cells solitary or in families of 2-4-8 within an old mother cell wall. (Euplanktont).

Cells 9-13 $\mu$ broad, 9-17 $\mu$ long.

Big (rr), Birch (1) (sss), Camp (r), Catfish (r), Devils (1) (rr), Duck (r), Found (rr), Green (2) (rr), Kawaguesaga (rr), Kitten (rrr), Long (2) (rr), Mendota (r), North Turtle (r), Pardee (rr), Rock (r), Winnebago (rr).

\section{Oocystis elliptica W. West. Pl. 22, Fig. 5.}

Jour. Roy. Micr. Soc. 1892: 736, pl. 10, fig. 56. 1892.

Cells oblong-elliptic, with poles rounded and without nodules. Chloroplasts 10-20, disciform, parietal, without (?) pyrenoids. Cells rarely solitary, generally in families of 4-8 within an old mother cell wall. (Tychoplanktont).

Cells 11-12.5 $\mu$ broad, 20-25 $\mu$ long.

Amicoy (rr). 
Oocystis Parva W. \& G. S. West. Pl. 22, Fig. 6.

Jour. of Bot. 36: 335. 1898; G. S. West, ibid. 37 : 223, pl. 394, figs. 14-17. 1399.

Cells broadly fusiform to elliptic, ends pointed but without polar nodules. Each cell with 1-3 parietal, laminate to disciform chloroplasts, with or without pyrenoids. Cells solitary or in families of 2-4-8. (Facultative Planktont).

Cells 4-7 $\mu$ broad; 6-12 $\mu$ long.

Beaver (1) (rr), Bettine (rr), Clear Crooked (rr), Cochrane (rrr), Crab ( $r r r)$, Deer (rr), George (rr), Half Moon (rr), Hooker (rr), Little Bass (2) (rr), Lynx (rr), Mendota (rr), Muskallonge (rr), Palmer (rr), Pine (1) (rr), Rudolph (rr), Sand (1) (rrr), Stone (rr), Wolf (rr).

\section{Oocystis gloeocystiformis Borge. Pl. 22, Fig. 7.}

Botaniska Studier till. F. R. Kjellman 23, pl. 1, figs. 1a-1b. 1906.

Cells narrowly elliptic with ends pointed. Chloroplast single, parietal, without a pyrenoid. Cells in families of $2-4$ within the old cell wall, several cell generations frequently forming a single colony. Wall enclosing colony with pointed ends but no polar nodules. (Tychoplanktont).

Breadth of cell 3-5.5 $\mu$; length 8-15 $\mu$.

Lac Court Oreilles (sss).

The old mother cell wall does not gelatinize as readily in this species as in others so that several cell generations are generally found in the same colony. The species is best recognized, however, by the sharply pointed ends of the colony wall.

\section{Oocystis lacustris Chodat. Pl. 22, Figs. 8-9.}

Bull. Herb. Boiss. 5: 119, pl. 10, figs. 1-7. 1897.

Cells elliptic to broadly fusiform, somewhat pointed and with a nodule at the poles. Chloroplasts 1-3, laminate, parietal, with or without pyrenoids. Margins of chloroplasts sometimes irregular. Cells rarely solitary, generally in families of $2-4-8$ within the old mother cell wall. (Euplanktont).

Cells 8-22 $\mu$ broad, 14-32 $\mu$ long.

Big Butternut (rr), Bone (rr), Center (r), Chain (rr), Chetek (r), Devils (2) (ss), Dummy (rr), Fowler (rr), Hillman (rr), Little Bass (2) (rr), Little Butternut (rrr), Long (2) (rrr), Long (3) (rrr), Mary (r), Mercer (rr), Palmer (rr), Pokegama (3) (rr), Prairie (rr), Reserve (rr), Sand (4) (rr), Sishebogema (rrr), Upper Nashotah (rrr), Upper Turtle (sss), White Sand (rr). 
Oocystis submarina Lagerheim. Pl. 22, Fig. 10.

Bot. Not. 1886: 45, fig. 1. 1886.

Cells oblong-cylindrical, 2-3 times as long as broad, somewhat pointed and with a nodule at each pole. Chloroplasts 1-2, laminate, parietal, usually with a pyrenoid. Cells rarely solitary, generally in families of 2-4-8-16 within the old mother cell wall. (Tychoplanktont).

Cells $3-9 \mu$ broad, $7-20 \mu$ long.

Camp (sss), Upper Nemahbin (rr).

Oocystis solitaria Wittrock. Pl. 22, Fig. 11.

Bot. Not. 1879: 24, figs. 1-5. 1879.

Cells ovoid to ellipsoid, solitary or in families of 2-4-8. Cell wall fairly thick and with conspicuous polar nodules. Chloroplasts numerous (generally 12-25), parietal, disciform to polygonal, with or without pyrenoids. (Facultative Planktont).

Cells 7-20 $\mu$ broad, 14-35 $\mu$ long.

Hooker (r), Sand (1) (rr).

Oocystis CRasSa Wittrock. Pl. 22, Figs. 12-13.

Bot. Not. 1880: 117. 1880.

Cells ovoid, length $11 / 2$ times the breadth, with a nodule at each pole. Chloroplasts 4-10 in number, fairly large, parietal, disciform to angular, generally with a pyrenoid. Cells solitary or in families of 2-4-8. Old cell wall enclosing the colony greatly distended. (Tychoplanktont).

Cells 10-20 $\mu$ broad, 14-26 $\mu$ long.

St. Croix (rr).

Oocystis eremosphaeria G. M. Smith. Pl. 23, Figs. 1-2.

Trang. Wis. Acad. Sci., Arts, \& Lett. 19': 630, pl. 14, figs. 8-9. 1918.

Cells ovoid, $1 \frac{1}{2}$ to 2 times as long as broad. Solitary or in families of 2-4. Chloroplasts numerous (40-60), parietal, lenticular, each containing a single pyrenoid. Cell wall thick, with a conspicuous polar nodule. (Facultative Planktont ?).

Cells 23-31 $\mu$ broad, 35-45 $\mu$ long.

Beaverdam (rr), Shell (sss). 
Oocystis PANdURIformis var. Minor G. M. Smith. Pl. 23, Fig. 3. Bull. Torr. Bot. Cl. 43: 471, pl. 24, fig. 2. 1916.

Cells oblong-ovoid, 2 to $2 \frac{1}{2}$ times as long as broad, sides slightly concave and poles with a conspicuous nodule. Chloroplasts numerous (15-25), parietal, disciform, and each containing a pyrenoid. Cells solitary or in families of 2-4-8. (Tychoplanktont).

Greatest diameter of cells 12-15 $\mu$, median diameter 11-14; length 30-35 $\mu$.

Star (rr).

This is the only species of the genus where the sides of the cells are concave.

Oocystis natans var. major var. nov. Pl. 23, Figs. 4-5,

Cells ovoid, without a conspicuous polar nodule. Chloroplasts 4-8, parietal, star-shaped or irregular, each chloroplast with a pyrenoid. More than two cell generations rarely found within the same mother cell wall. (Facultative Planktont).

Cells 16-25 $\mu$ broad, 31-38 $\mu$ long. Families up to $90 \times 120 \mu$.

Birch (2) (sss), Chetac (s), Rice (1) (rr).

Lemmermann founded the genus Oocystella upon this stellate nature of the chloroplast (Zeits. f. Fischeri u. d. Hilfsw. 11: 103. 1903) but the genus has not been recognized and the single species is placed in Oocystis.

\section{NEPHROCYTIUM Nägeli 1849.}

Cells ovoid, reniform, or oblong-elliptic; generally in colonies of 2-4-8-16 cells within the partially gelatinized remains of the old mother cell wall. Arrangement of cells in young colonies spiral, in old colonies irregular. Chloroplast single and expanded at first, later fragmenting and becoming diffuse; pyrenoid single.

Reproduction by the formation of 2-4-8-16 autospores in each cell.

Nephrocytium Agardhianum Nägeli. Pl. 23, Figs. 6-7. Gatt. einz. Algen 79, pl. 3, figs. Ca-Cp. 1849.

Cells reniform, generally spirally arranged in young colonies. Chloroplast single, parietal, laminate, and with one pyrenoid in young cells; diffuse in old cells. (Tychoplanktont).

Cells 2-12 $\mu$ broad, $6-28 \mu$ long; colonies up to $60 \mu$ long.

Bear (3) (rrr), Bear Trap (rrr), Camp (rr), Hillman (rr), Little Bass (rrr), Mendota (rr), Mill (rrr). 


\section{GLOEOTAENIUM Hansgirg 1890.}

Cells spherical, ovoid, or variously flattened; solitary or united in colonies of 2-4-8 cells enclosed by a non-expanded mother cell wall and scparated from one another by a dark colored gelatinous mass that lies between the cells. Colonies rectangular, with rounded corners in front view; oblong with sharp corners in side view. Cell wall thick, distinctly lamellated; old cell wall enclosing the colony frequently with folds and gelatinous dises opposite the cells. Chloroplast entirely filling cells; with or without a pyrenoid.

Reproduction by autospores and aplanospores.

Gloeotaenium Loitlesbergerianum Hansgirg. Pl. 23, Figs. 8-9.

Sitzbr. d. k. böhm. Ges. d. Wiss. in Prag, Jahrgang 1890: 10. 1890; Transeau, Bot. Gaz. 55: 66, pl. 3, figs. 1-24. 1913.

Cells spherical to ovoid, completely filling the space inside of old mother cell wall. (Tychoplanktont).

Diam. cells 20-30 $\mu$; length 2-celled colonies 40-70 $\mu$ breadth 22-40 $\mu$; thickness $20-30 \mu$. 4-celled colonies $40-70 \mu$ broad, 40-80 $\mu$ long.

Big Butternut (rrr).

\section{Sub-family TETRAEDREAE.}

Cells always solitary, without a gelatinous envelope, flattened or isodiametric, triangular, quadrangular, or polyangular; angles simple or produced into spines or long hyaline setae.

KEY TO THE GENERA.

Cells simple or with fairly stout spines at angles............ Tetrakdron Cells with long hyaline setae at angles................. PoLYEDRIOPSIS

\section{TETRAEDRON Kützing 1845.}

Cells solitary, free-floating, flattened or isodiametric, triangular, quadrangular, or polyangular. Angles simple or produced into simple or furcate spines. Cell wall smooth or verrucose. Chloroplasts one to many, parietal, disciform to angular; or completely filling the cell; with or without pyrenoids.

Reproduction by division of cell contents into 4-8 autospores that are liberated by the rupture of the old mother cell wall. 


\section{KEY TO THE SPECIES.}

Angles of cells never produced into processes.

Corners of cells without spines.

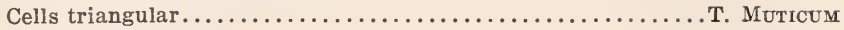

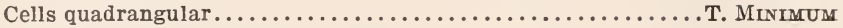

Corners of cells with spines.

All cell corners in the same plane.

Cells triangular.............................................

Cells with more than three angles.

Cells with four angles................ R. REGULARE v. INcus (p. p.)

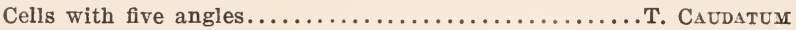

All cell corners not in the same plane.

Cells quadrangular.

Pyramidal cells........................... REg ULARE

Halves of cells twisted over one another.

Wall smooth.

Angles delicately tapering............. Victorieae var. MAJok

Angles strongly convex.......... T. REgulare var. Torsum (p.p.)

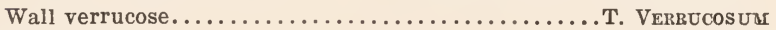

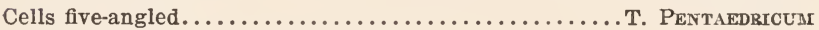

Angles at corners produced into processes.

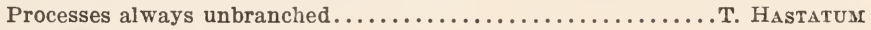

Processes always branched.

Cells flattened and processes in the same plane.

General outline of cell H-shaped................. Constricum

General outline of cell not H-shaped.

Processes long, conspicuously branched............... Gracile

Processes short, not conspicuously branched....T. LoBULAtuM (p. p.)

Cells isodiametric and processes not in the same plane.

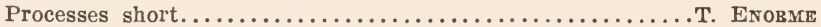

Processes long.

With 3-5 series of branchings...... T. Lobulatum var. PolyfurcatuM

Never more than three series of branchings.

Diameter of cells always greater than the length

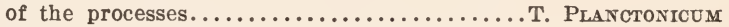

Diameter of cell always less than the length of

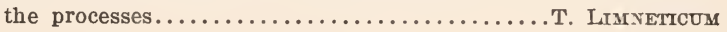

Tetraedron muticum var. PUnctulatum (Reinsch) de Toni. Pl. 23, Figs. 10-13.

Sylloge algarum 1: 600. 1889.

Polyedrium muticum var. punctulatum Reinsch, Notarisia 3: 498, pl. 4, fg. 6. 1888.

Cells small, triangular, somewhat flattened. Sides of cells convex in front view. Corners sharp but without spines. Cell wall covered with small granules. (Tychoplanktont).

Diam. cells 15-20 $\mu$; thickness 8-10 $\mu$.

Beaverdam (rr), Deer (rrr), Sand (2) (rr). 
Tetraedron trigonum (Nägeli) Hansgirg. Pl. 23, Figs. 14-16. Hedwigla 27: 130. 1888.

Polyedrium trigonum Nägeli, Gatt. einz. Algen 84, pl. 4, figs. B1a-B1b. 1849.

Cells medium sized, triangular, flattened. Sides of cells generally concave, rarely straight. Corners with a single, stout, straight or curved spine. (Facultative Planktont).

Diam. cells (without spines) 20-30 $\mu$; length spines 8-10 $\mu$.

Crawling Stone (rrr), High (r), Pokegama (1) (rr), Rice (1) (rrr), Tenderfoot (rr), Tied Canoe (rrr).

var. Setigerum (Archer) Lemmermann. Pl. 24, Figs. 1-4.

Arkiv. för Botanik 2, No. 2: 110. 1904.

Tetrapedia setigera Archer, Quart. Jour. Micr. Sci. N. S. 12: 365, pl. 21, figs. 14-17. 1872; Grevillea 1: 46, pl. 3, figs. 14-17. 1872; G. S. West, Brit. Freshw. Algae 349. 1904; de Toni, Sylloge algarum 5: 113. 1907.

Polyedrium trigonum var. setigerum (Archer) Schröder, Forschungsbr. a. d. Biol. Stat. zu Plön 6: 23, pl. 1, fig. 6. 1898.

Cells small, triangular, flattened, with a conspicuous emargination on each side in front view. Corners of cells rounded and produced into a long delicately tapering spine. Chloroplast single, filling the entire cell; with one pyrenoid. (Facultative Planktont).

Diam. cells (without spine) 7-9 $\mu$; length of spines 12-15 $\mu$.

White Ash ( $r$ ).

G. S. West and de Toni follow Archer in considering this organism a member of the Myxophyceae West stating; "T. setigera Archer is a beautiful little species known from N. W. Scotland and W. Ireland, which has been erroneously referred by some authors to the chlorophyceous genus Tetraëdron. The cell contents of Tetrapedia setigera are homogeneous and of a pale blue-green color." The cell contents of the individuals that I have observed are distinctly grass green in color and contain a single pyrenoid. This pyrenoid has not been noted by either Archer or Schröder. Since the shape and dimensions of the ceis that I have found are exactly the same as those given by Archer I believe that I am dealing with the same organism that he described and one which is a member of the Chlorophyceae and not the Myxophyceae.

var. gracile (Reinsch) de Toni. Pl. 24, Figs. 5-9.

Sylloge algarum 1: 598, 1889; Printz, Kgl. Norske Vidensk. Selsk. Skr. 1915, No. 4: 29, pl. 3, figs. 167-169. 1916.

Polyedrium trigonum var. gracile Reinsch, Die Algenfl. d. mitt. Th. จ. Franken 75: pl. 3, figs. 1am 1b. 1867.

Tetraëdron proteiforme G. M. Smith non (Turner) Brunnthaler, Trans. Wis. Acad. Sci., Arts, \& Lett. 19': 632, pl. 15, figs. 4-5. 1918. 
Cells triangular, flattened, concavity of sides very marked. Angles of cells ending in short spines. Several parietal, disciform chloroplasts without pyrenoids. (Facultative Planktont).

Cells $23-50 \mu$ broad; $6-10 \mu$ thick.

Blake (rr), Chain (r), Cochrane (r), Fishtrap (rr), Horse (r), Lac Court Oreilles (rr), Little Bear (rr), Little Crooked (rrr), Loon (rr), Paddock (rrr), Palmer (rrr), Rice (1) (rr), Tenderfoot (r), Tied Canoe (rrr), White Ash (rr), Wolf (rr).

In the second list of Wisconsin algae this alga was given as $T$. proteiforme but I am now convinced that it is $T$. trigonum var. gracile. The cells reach a much larger size than that given by Reinsch and the excavation of the sides may be very much greater; in fact the cells are at times so delicate that they might be placed as Cerasterias species had not other individuals in the same collection the ordinary cell shape of T. trigonum var. gracile.

Tetraedron minimum (A. Braun) Hansgirg. Pl. 24, Figs. 10-13. Hedwigia 27: 131. 1888; G. S. West, Brit. Freshw. Algae 231, fig. 101A, 1904.

Cells small, flattened, front view square or oblong with slightly rounded corners and concave sides. Side view fusiform-elliptic. Wall smooth or finely granulate. Chloroplast single, parietal, with one pyrenoid. (Facultative Planktont).

Cells 6-20 $\mu$ long, 5-8 $\mu$ thick.

Beaver (2) (rrr), Camp (rr), Deer (rrr), Hillman (rrr), Horse (rr), Little Bass (2) (rrr), Little Doctor (rr), Mendota (rrr), Okauchee (rrr), Paddock (rrr), Round (3) (rrr).

Tetraedron regulare Kützing. Pl. 24, Fig. 14.

Phycol. germanica 129.1845.

Polyedrium tetraedricum Nägeli, Gatt. einz. Algen $84, p l$. 4, figs. B3a-B3b. 1849.

Cells medium sized, tetragonal, generally pyramidal, sides concare, straight, or slightly convex. Angles with a single, heavy, short, blunt, spine. (Tychoplanktont).

Diam. cells (with spines) $14-45 \mu$.

Blake (rr).

var. INcus Teiling. PI. 24, Figs. 15-16.

Sv. Bot. Tids. 6: 277, 274, fig. 12.1912.

Polyedrium regulare Chodat non Kützing, Matér. pour la flore crypt. Suisse $1^{3}$ : 220, fig. 146.1902.

Cells small, tetragonal, flattened or pyramidal, sides slightly concave. Angles produced into a single short delicate straight or curved spine. (Tychoplanktont). 
Diam. cells (without spine) 13-18 $\mu$; length of spines 7-8 $\mu$.

\section{Poor Farm (rr).}

This is probably what Chodat has figured as $T$. regulare. It differs from the typical form in the smaller size, constantly concave sides of the cell, and the delicate spines at the cell angles.

var. TORSUM (Turner) Brunnthaler. Pl. 24, Figs. 17-18.

in Pascher, Süsswasserfl. Deutschl., österr. u. d. Schw. 5²: 150, fig. 163. 1915.

Cells medium sized, tetragonal, with the two halves of the cells cruciately arranged. Sides of cells straight or convex. Angles of cells with a single short stout spine (Facultative Planktont).

Diam. cells $25-40 \mu$.

Horse (sss).

Over a hundred individuals were observed in the plankton eatch from this lake and the twisting of the cell halves was a very constant character.

Tetraëdron victorieae var. major var. nov. Pl 24, Figs. 19-22; Pl. 25, Fig. 1.

Cells medium sized, four-sided, with two deeply emarginate sides dividing the cell into two cruciately arranged halves. Sides of cells, in vertical view, broadly fusiform with acute apices. All angles of cells with a single heavy straight spine (Euplanktont).

Cells (with spines) 30-60 $\mu$ long; 15-20 $\mu$ broad.

Chain (r).

The cell shape and the peculiar twisting of the two halves is identical with that of $T$. victorieae Woloszynska (Hedwigia 55: 203, pl. 6, figs. 1-4. 1914) which is known from the plankton of Lake Victoria Nyanza, Africa. Measurement of about 25 Wisconsin individuals give the following variation in size, length $30-60 \mu$, breadth $15-20$; whereas the length of the African individuals varies from 20 to $30 \mu$ and the breadth $10-15 \mu$.

Tetraedron verrucosum G. M. Smith. Pl. 25, Figs. 2-3.

Trans. Wis. Acad. Sci., Arts, \& Lett. 19': 632, pl. 15, figs. 1-2. 1918.

Cells large, tetragonal, pyramidate, or with the halves cruciate. Sides convex. Angles of cell terminating in a very heavy, blunt spine. Cell wall thick, verrucose. (Euplanktont).

Diam. cells (with spines) $65-80 \mu$; length of spines 13-18 $\mu$.

Bear (1) (rr). 
Tetraedron caudatum (Corda) Hansgirg. Pl. 25, Figs. 4-7. Hedwigia 27: 131. 1888; G. S. West, Brit. Freshw. Algae 231, fig. 101в. 1904.

Cells small, flattened, five-sided; four of the sides concave and the fifth deeply incised. Angles rounded and produced into a single straight spine that lies parallel with the flat side of the cell. (Tychoplanktont).

Diam. cells 6-22 $\mu$; length of spines 1-3.5 $\mu$.

Chain (rrr), East (rrr), Dutchmans (rrr), Horse (rr), Lake of the Woods (rrr), Mendota (rrr), Palmer (rrr), Reserve (rrr), Wild Goose (rrr).

The notch at one side of the cell varies considerably in depth but is always deeper than the incurving of the other four sides.

var. Longispinum Lemmermann. Pl. 25, Figs. 8-12.

Bot. Cent. 76: 151. 1898; Forschungsbr. a. d. Biol. Stat. zu Plön 7: 117, pl. 1, jigs. 8-9. 1899.

Spines on corners at right angles to the flat side of the cell, generally two pointing in one direction and three in the other. Spines much longer than in the typical form. (Euplanktont).

Diam. cells (without spines) 8-18 $\mu$; length of spines $3-8 \mu$.

Pine Tree (r), Travis (sss)

This is a sharply defined variety, differing from the typical form in the bending of the spines so that they lie at right angles to the plane of the cell. Lemmermann's figure 9 shows this very well but for some reason the cell in his figure 8 has no spines and so is not at all characteristic.

Tetraedron Pentaedricum W. \& G. S. West. Pl. 25, Figs. 13-17. Trans. Linn. Soc. 2nd Ser. Bot. 5: 84, pl. 5, figs. 15-16. 1895.

Cells small, five-cornered, with four corners in one plane and the fifth lying at an angle of 30-90 degrees. Corners subacute, each with a single, short, curved spine. Chloroplast single, parietal, with one pyrenoid. (Facultative Planktont).

Diam. cells (without spines) 5.5-14 $\mu$, (with spines) 9-20 $\mu$.

Soft (rr).

T. pentaëdricum has not been observed since it was described from Madagascar by the Wests. Chodat considers it a synonym of T. caudatum (Corda) Hansg. erroneously citing it as Tetrapedia pentaëdricum (Matér. pour la fl. crypt. Suisse $1^{3}: 219$. 1902). Isolation of this 
alga in pure culture with the retention of its distinguishing character shows that the Wests are correct in considering it a distinct species. It resembles $T$. caudatum in the size, number of corners, character of spines at the corners, and the concave sides; but differs in having four corners in approximately the same plane and the fifth at an angle with the plane of the other four. There is considerable variation in the angle at which this fifth corner lies but it is never in the same plane as the other corners. The Wests (1. c. fig. 17) also describe a variety minima which, as the name implies, is smaller. I find that the variations in size of cells of the typical form in a pure culture include the dimensions set for the variety minima so that this variety cannot be recognized.

\section{Tetraedron hastatum (Reinsch) Hansgirg. Pl. 25, Fig. 18.}

Hedwigia 27: 132. 1888.

Polyedrium tetraedricum var. hastatum Reinsch, Die Algenfl. d. mitt. Th. v. Franken 77, pl. 5, figs. 3a-3b. 1867.

Cells medium sized, pyramidate, with the angles produced into long tapering and somewhat concave processes. Processes unbranched but having 2 or 3 short spines at the tip. (Tychoplanktont).

Diam. cells (with processes) $28-36 \mu$; diam. base of process $8 \mu$.

Horse (rrr).

The general shape of the cell is similar to that of $T$. limneticum but there is no branching of the processes.

var. Palatinum (Schmidle) Lemmermann. Pl. 25, Figs. 19-21.

Ber. d. D. bot. Ges. 20: (247). 1902.

Polyedrium hastatum var. palatinum Schmidle, Ber. d. D. bot. Ges. 18: 148, 149, pl. 6, figs. 4-5. 1900.

Cells pyramidal, with convex sides, angles produced into fairly delicate non-tapering processes about as long as the diameter of the cells. Processes unbranched but with three short spines at the apex. (Tychoplanktont).

Diam. cells (without processes) 4-14 $\mu$; length processes about $10 \mu$.

Horse ( $r r)$.

The processes at the angles of the cell do not seem as much a part of the cell as in the typical form. Although both the typical form and the variety palatinum were found at the same station the two seem distinct and without transition forms. 
Tetraëdron constrictum nom. nov. Pl. 25, Figs. 22-24.

Tetraëdron arthrodesmiforme var. lobulatum Woloszynska, Hedwigia 55: 203, pl. 6, fig. 11.1914.

Cells medium sized, tetragonal, flattened, two sides straight and two opposite sides concave. Angles produced into narrow slightly tapering processes which give the cell a decided H-shape. Ends of processes generally dichotomously branched the branchlets ending in two short spines. (Euplanktont).

Diam. cells (without processes) 5-8 $\mu$; length 18-25 $\mu$; thickness $8 \mu$. Length of processes 10-15 $\mu$.

Bone (rr).

Woloszynska has found these peculiar $\mathrm{H}$-shaped cells in the plankton of Lake Victoria Nyanza, Africa and placed them among other varieties of $T$. arthrodesmiforme described at the same time. The variety lobulatum is, however, sufficiently different from the other varieties to warrant raising it to specific rank. Bone lake is the only station where it has been found but several individuals were seen in the catch from this lake.

Tetraedron gracile (Reinsch) Hansgirg. Pl. 26, Figs. 1-5.

Hedwigia 28: 19.1889.

Polyedrium gracile Reinsch, Notarisia 3: 502, pl. 7, figs. 1a-1c. 1888.

Cells medium size, conspicuously flattened, rectangular, with flattened sides. Angles of cells produced into narrow processes that generally branch twice and end in minute spines. The primary branchings of the processes are at an angle of 90 degrees with one another and always parallel with a side of the cell. Each cell containing several, parietal disciform to laminate chloroplasts without pyrenoids. (Euplanktont).

Diam. cells (without processes) $15-30 \mu$; (with processes) $35-80 \mu$; thickness of cells 6-12 $\mu$.

Bear (1) (rr), Bear Trap (rrr), Blake (rr), Chain (rr), Elizabeth (rrr), Hillman (sss), Loon (rrr), Pine (2) (rr), Poor Farm (rr), Round (rr), Travis (r), Wapagossett (rr).

Tetraedron lobulatum (Nägeli) Hansgirg. Pl. 26, Figs. 6-7.

Hedwigia 27: 132.1888.

Polyedrium lobulatum Nägeli, Gatt. einz. Algen 84, pl. 4, figs. B4a-B4b. 1849.

Cells medium sized, tetragonal, flattened, or pyramidal. Processes of angles with one or two short dichotomous branchings that generally do not end in spines. Sides of cells distinctly concave. Cells contain- 
ing several parietal disciform chloroplasts without pyrenoids. (Tychoplanktont).

Diam. cells (with processes) $30-40 \mu$.

Birch Island (rrr), Long (3) (rrr), Sand (2) (rr).

The specimens from Sand lake were of particular interest since three showed the production of autospores (fig. 6). The chloroplast of old cells are frequently indistinct but they can be seen quite readily in young cells.

var. polyfurcatum G. M. Smith. P1. 26, Fig. 8.

Bull. Torr. Bot. Cl. 43: 480, pl. 26, figs. 21-22. 1916.

Cells tetragonal, flattened or pyramidal; with concave, straight, or slightly convex sides. Processes at angles somewhat tapering, 3-5 times dichotomously branching, the ultimate branchlets with 2-3 minute spines. (Facultative Planktont).

Diam. cells (without processes) $15-25 \mu$, (with processes) $35-70 \mu$.

Beaverdam (r), Blake (rr), Bone (rr), Clare (rr), Fish (rr), Loon (rr), Muskallonge (rrr), Palmer (r), Pardee (r), Pine Tree (rr), Rice (1) (rr), Shell (rr), Wild Goose (rrr).

Differing from the typical form in the greater branching of the processes and from $T$. enorme (Ralfs) Hansg. in the much longer processes.

Tetraedron limneticum Borge. Pl. 27, Figs. 1-3.

Bct. Not. 1900: 5, pl. 1, fig. 2. 1900; W. \& G. S. West, Trans. Roy. Soc. Edinburgh 41: 507, pl. 6, figs. 10-11. 1905.

Cells of medium size, tetragonal, pyramidal, the four angles being produced into one or two dichotomous branchings. Terminal branchlets with 2-3 short spines. (Euplanktont).

Diam. cells (with processes) 45-85 $\mu$; diam. base of processes 8-12 $\mu$.

Chain (rr), Chetek (r), Clear (r), Crawling Stone (rrr), Deer (rr), Diamond (rrr), Island (rr), Kitten (rr), Little Butternut (rr), Little Crooked (rrr), Mud (2) (r), Nancy (rr), Palmer (rr), Pine Tree (rr), Poplar (rr), Spirit (rrr), Squirrel (rr), Wildcat (rr), Wild Goose (rrr), Wolf (rr).

Tetraedron planctonicum G. M. Smith. Pl. 27, Figs. 4-5. Bull. Torr. Bot. Cl. 43: 479, pt. 26, figs. 19-20. 1916.

Cells medium-sized, four to five sided, sides concave to convex. Angles of cells produced into narrow, once to twice dichotomously branched processes. Ultimate branchlets with 2-3 short spines. Processes brofd in front view, narrow in side or vertical view. (Euplanktont). 
Diam. cells (without processes) $18-30 \mu$; (with processes) $45-60 \mu$.

Cranberry (rr), Cochrane (rr), Devils (2) (sss), Granite (rr), Horseshoe (1) (rr), Lindy (rrr), Lost (rr), No Mans (rr), Prairie (rr), Rock (rr), Vermilion $(r)$.

The chief difference between this species and $T$. limneticum is the greater size of the cells in proportion to the length of the processes.

\section{Tetraedron enorme (Ralfs) Hansgirg. Pl. 27, Fig. 6.}

Hedwigia 27: 132. 1888; G. S. West, Brit. Freshw. Algae 231, fig. 101D. 1904.

Cells irregularly tetrahedric, angles produced into short processes and sides emarginate. Processes generally bilobed and ending in short spines. (Tychoplanktont).

Diam. cells $25-45 \mu$.

Carson (rr), Cochrane (rr), Devils (2) (r), Horse (rrr), Horseshoe (2) (rrr), Lake of the Woods (rrr), Okauchee (rrr), Pine (2) (rr).

\section{POLYEDRIOPSIS Schmidle 1899.}

Cells solitary, generally tetragonal, flattened; rarely pyramidal $\mathrm{cr}$ with sides cruciate. Cormers truncate and with 3-10 long, hyaline, slightly tapering setae. Chloroplast parietal or entirely filling the cell, pyrenoid single.

Reproduction by the formation of 2-4-8 autospores through the division of the cell contents.

\section{Polyedriopsis spinulosa Schmidle. Pl. 27, Figs. 7-8.}

Allg. Bot. Zeitschr. 5: 17.1899.

Tetraëdron spinulosum Schmidle, 1bid. 2: 193, fig. 2. 1896.

Characters the same as those of the genus. (Euplanktont).

Greatest diameter of cells 12-25 $\mu$; length of setae about $40 \mu$.

Horse (rr), Prairie (rrr).

The general tendency among phycologists is to follow Wille's practice and place the alga in a special sub-genus of Tetraëdron. The setae on the cell angles are of the same type as those found on Lagerheimia and Micractinium so that Polyedriopsis forms, in my opinion, a genus parallel with Tetraëdron just as Lagerheimia does with Oocystis. 


\section{Sub-family MICRACTINIEAE.}

Cells solitary or in colonies; spherical or ovoid; with long hyaline setae or spines completely covering or restricted to certain parts of the cell wall. Chloroplast single and cup-shaped; or laminate to disciform and from one to several in each cell. Chloroplasts generally with pyrenoids.

Cells spherical.

\section{KEY TO THE GENERA.}

Cells organized into definite colonies...................

Cells solitary.

Wall covered with fine hair-like setae.

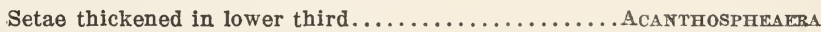

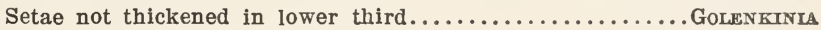

Wall covered with delicately tapering spines......... ECHINOSPHAERELLA Cells ovoid.

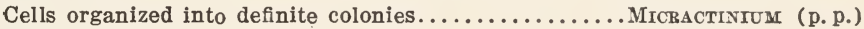

Cells solitary.

Setae somewhat tapering $\ldots \ldots \ldots \ldots \ldots \ldots \ldots \ldots \ldots \ldots \ldots \ldots \ldots \ldots \ldots \ldots$ LAGRHETM

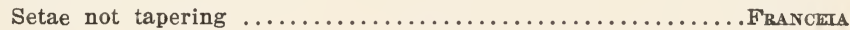

\section{MICRACTINIUM Fresenius 1858.}

Cells spherical or ovoid, in colonies of 4-32 or more, generally quadrately arranged in one plane but sometimes tetrahedrically disposed. Cell wall delicate, with 1-7 long hyaline setae that are not thickened at the base lying on the free surface of the cells. Chloroplast single, parietal, cup-shaped; with one pyrenoid.

Reproduction by the division of contents of any cell to form a 4- or 8-celled autocolony, the young colony being liberated by a rupture of the mother cell wall into four parts. Young coenobia frequently remaining attached to the parent coenobe for some time.

KEY TO THE SPECIES.

Cells spherical .M. Posmlun

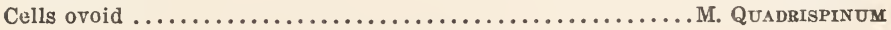

\section{Micractinium pusillum Fresenius. Pl. 28, Figs. 1-3.}

Abh. Senckenb. Naturf. Ges. 2: 236, pl. 11, figs. 46-49. 1858; G. M. Smith, Bull. Torr. Bot. Cl. 43: 477, pl. 25, fig. 18.1916.

Richteriella botryoides (Schmidle) Lemmermann, Hedwigia 37: 307, pl. 10, figs. 1-6. 1898.

Richteriella botryoides forma fenestrata Chodat, Matér. pour la flore crypt. Suisse 13: 194, fig. 110. 1902. 
Richteriella botryoides forma tetraedrica Lemmermann, Arch. f. Hydrobiol. u. Planktonkde. 5: 307.1910.

Colonies of 4-8-16 or more cells in groups of four and disposed in a quadrate or pyramidate manner with the groups of four in turn pyramidately or quadrately arranged. Cells spherical, with 1-5 long, hyaline, delicately tapering setae on the face not adjacent to other cells. Chloroplast single, parietal, cup-shaped; with one pyrenoid. (Euplanktont).

Diam. cells (without setae) 3-7 $\mu$; length of setae 20-35 $\mu$.

Blake (rrr), Bone (sss), Chain (sss), Chetek (rr), East (rr), Green (1) (rr), Hooker (rr), Horse (rr), Horseshoe (2) (rrr), Island (rrr), Little Bass (2) ( $r$ ), Little Crooked (rrr), Loveless ( $r$ ), Mendota (rr), Monona (cc), North Turtle (rr), Pokegama (3) (rr), Poor Farm (rr), Pope (rr), Prairie (rr), Round (1) (rr), Tenderfoot (rrr), Tied Canoe (rr), Wolf (rrr).

Flat sixteen-celled colonies with a central open space are the most common. Such colonies have been given the form name fenestrata but both it and the form tetraedrica are unworthy of recognition. On rare cccasions large colonies are found; colonies containing over 750 cells having been collected from the plankton of Lake Monona.

\section{var. elegans G. M. Smith. Pl. 29, Fig. 1.}

Trans. Wis. Acad. Sci., Arts, \& Lett. 19': 631, pl. 12, fig. 4. 1918.

Cells with 5-7 setae on the exposed face. Dimensions as in the typical form. (Euplanktont).

Rice (1) (rr).

This seems to be a distinct variety since the cells of colonies from this lake all bore the large number of setae.

Micractinium quadrisetum (Lemmermann) G. M. Smith. Pl. 28, Fig. 4.

Bull. Torr. Bot. Cl. 43: 479, pl. 25, fig. 17. 1916.

Cells ovoid, with 1-4 long, delicately tapering setae on the exposed faces. Chloroplast single, parietal, cup-shaped; with one pyrenoid. (Euplanktont).

Diam. cells (without setae) 4-7 $\mu$, length 8-10 $\mu$; length of setae $23-40 \mu$.

Bear Trap (rrr), Camp (rr), Cranberry (rrr), Eagle (rrr).

The cells of this species are somewhat larger than those of $M$. pusitlum and are distinctly ovoid. The character upon which the specific 
name is based is quite misleading since the number of setae may vary from one to four. Colonies containing more than sixteen cells have not been observed and the cell arrangement has been quadrate in every case.

\section{GOLENKINIA Chodat 1894.}

Cells spherical, normally solitary; occasionally forming temporary colonies. Cell wall thin, sometimes enclosed in a thin gelatinous envelope. Surface of cell covered with hyaline setae that are slightly tapering but not conspicuously thickened in the lower third. Chloroplast single, parietal and cup-shaped or entirely filling the cell; pyrenoid single.

Reproduction by the formation of autospores. Zoospores have been reported but their formation is doubtful.

KEY TO THE SPECIES.

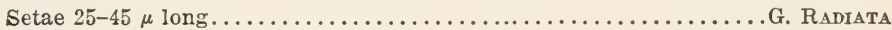

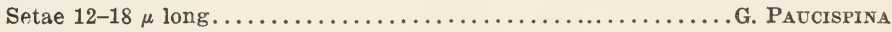

Golenkinia radiata Chodat. Pl. 29, Figs. 2-3.

Jour. de Bot. 8: 305, pl. 3, figs. 1-24. 1894.

Cells spherical, solitary, sometimes in temporary colonies of four cells. Entire cell wall covered with long, delicate, hyaline setae. Chloroplast single, cup-shaped, parietal; with one pyrenoid. (Euplanktont).

Diam. cells (without setae) 7-15 $\mu$; length setae 25-45 $\mu$.

Green (2) (rrr), White Ash (rr).

This and the following Golenkinia species have been made a subgenus of Micractinium by Wille and that terminology followed in the second list but the colonial and solitary habit seem to me sufficiently diverse to warrant generic distinction.

Golenkinia paucispina W. \& G. S. West. Pl. 29, Figs. 4-5. Trans. Roy. Irish Acad. 32, Sec. B: 68, pl. 1, fig. 18. 1902.

Cells solitary, spherical, with few to fairly numerous, short, delicately tapering, hyaline or dark setae. Chloroplast single, completely filling the cell, with one pyrenoid. (Euplanktont).

Diam. cells (without setae) 15-18 $\mu$; length setae 12-18 $\mu$.

Prairle (rr).

The setae of the cells in Prairie lake were more numerous than the Wests found them in individuals from the plankton of Lough Neagh, 
Ireland. They were also dark colored and are more conspicuous than in other members of the Micractineae.

\section{ACANTHOSPHAERA Lemmermann 1899.}

Cells spherical, solitary, with a single cup-shaped chloroplast containing one pyrenoid. Cell wall thin, without a gelatinous sheath; covered with many long hyaline setae that are thicker in the lower third and then abruptly diminish to a very fine hair.

Method of reproduction unknown.

Acanthosphaera Zachariasi Lemmermann. Pl. 29, Figs. 6-8.

Forschungsbr. a. d. Biol. Stat. zu Plön 7: 118, pl. 1, figs. 10-11. 1899.

Characters as those of the genus. (Euplanktont).

Diam. cells (without setae) 9-14.5 $\mu$; length setae 30-35 $\mu$.

Horse (rr).

The chief distinction between this genus and Golenkinia is the thickening of the lower part of the setae.

Echinosphaerella gen. nov.

Cells spherical, solitary. Cell wall thin, completely covered with heavy, long, hyaline, delicately tapering and slightly concave, homogeneous spines. Chloroplast single, parietal, cup-shaped; with one pyrenoid.

Reproduction unknown.

Echinosphaerella limnetica sp. nov. Pl. 29, Figs. 9-11.

Characters as described above. (Euplanktont).

Diam. cells (without spines) 9-12 $\mu$. Spines $2.5-3 \mu$ broad at base, 20-25 $\mu$ long.

Horse (rr).

The alga at once suggests a desmid zygospore, especially those of certain Staurastrum species. In all desmid zygospores the chloroplast is not definite and since the alga collected from Horse Lake has a single, well defined, cup-shaped chloroplast with one pyrenoid the presumption is that it is a vegetative cell and not a zygospore. The nearest genus is Echinosphaeridium Lemmermann where the setae covering the wall have a broad tapering gelatinous sheath at the base. In Echinosphaerella there is not a central hair-like seta with a gelatinous covering, but a homogeneous spine of considerable thickness at the 
base. Although the genus is provisionally placed in the Micractinieae its spines are quite different from those of other genera of the subfamily.

\section{LAGERHEIMIA Chodat 1895.}

Cells solitary; ovoid, ellipsoid, or citriform. Cell wall firm, without a gelatinous sheath; with long tapering setae that lie a short distance back from the poles or cover the entire wall. Chloroplasts $1-4$, parietal, laminate; with or without pyrenoids.

Reproduction by autospores that are generally liberated at once but which may remain inside the old mother wall a short time.

\section{KEY TO THE SPECIES.}

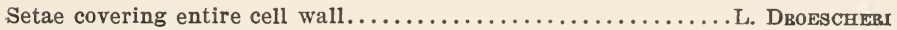
Setae confined to poles of the cell.

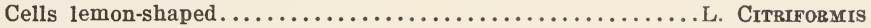
Cells ovoid.

Length of setae more than double that of cell............. LoNGiseta Length of setae less than double that of cell.

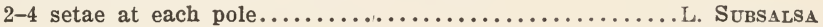
3-8 (generally 6) setae at each pole................... Crumata

Lagerheimia ciliata (Lagerheim) Chodat. Pl. 31, Figs. 1-2.

Nuova Notarisia 10: 90.1895.

Oocystis ciliata Lagerheim, öfvsers Kgl. Vet.-Ak. Förh. 39, No. 2: 76, pl. 3, figs. 33-37. 1882.

Chodatella ciliata (Lag.) Lemmermann, Hedwigia 37: 310. 1898.

Cells oblong-ovoid, with 3-7, hyaline, delicately tapering setae at each pole. Chloroplasts 1-4, parietal, laminate; each with a single pyrenoid. (Euplanktont).

Breadth of cells (without setae) 6-18 $\mu$; length (without setae) 10 $21 \mu$. Setae $15-20 \mu$ long.

Kegonsa (rr), Mendota (sss).

The setae of this species are not in definite whorls but distributed over the entire polar region.

var. minor (G. M. Smith) comb. nov. Pl. 31, Fig. 3.

Chodatella ciliata var. minor G. M. Smith. Bull. Torr. Bot. Cl. 43: 477, pl. 25, fig. 16. 1916.

Cells ovoid, with 6-8 setae at each pole. (Euplanktont).

Diam. cells (without setae) 6-7.5 $\mu$; length (without setae) 8-10 $\mu$. Setae about $20 \mu$ long.

Muskallonge ( $r r)$. 
Lagerheimia subsalsa Lemmermann. Pl. 30, Figs. 3-4.

Forschungsbr. a. đ. Blol. Stat. zu Plön 6: 193, pl. 5, figs. 2-6. 1898.

Chodatella subsalsa Lemmermann, Hedwigia 37: 310. 1898.

Cells ovoid, with 2-4 delicate setae at each pole. Chloroplast single, laminate, parietal; with one pyrenoid. (Euplanktont).

Diam. cells (without setae) 2.5-8 $\mu$; length (without setae) 5-12 $\mu$. Setae 7.5-26 $\mu$ long.

Deer (rrr), Geneva (rr).

Lagerheimia longiseta (Lemmermann) Printz. Pl. 30, Figs. 8-9. Skr. Vidensk. 1 Kristiania, Mat.-Naturv. Kl. 1913', No. 6: 60. 1914.

Chodatella longiseta Lemmermann, Hedwigia 37: 310, pl. 10, figs. 11-18. 1898 .

Cells ellipsoid, with a whorl of 4-10 long, hyaline, delicately tapering setae a short distance from each pole. Chloroplast single (?), parietal; without a pyrenoid (?). (Euplanktont).

Breadth of cells (without setae) 5-8 $\mu$; length (without setae) 9-13 $\mu$. Setae $40-55 \mu$ long.

White Sand (sss).

The exceedingly long setae at once distinguish the species from all others. The arrangement of the setae in a whorl is best seen in an end view of a cell.

var. major var. nov. Pl. 30, Figs. 10-12.

Cells ovoid, with somewhat pointed ends. With a whorl of 4-7 setae ¿ short distance from each pole. Cells containing 1-2 laminate parietal chloroplasts each with a single pyrenoid. (Euplanktont).

Breadth of cells (without setae) 12-15 $\mu$; length (without setae) 15-22 $\mu$. Setae 45-60 $\mu$ long.

Blake (rr), Little Bass (2) (rrr).

The variety is distinguished from the typical form by the more pointed and larger cells.

Lagerheimia citriformis (Snow) comb. nov. Pl. 30, Figs. 1-2.

Chodatella citriformis Snow, Bull. U. S. Flsh Comm. 22: 389, pl. 2, figs. $8^{1}-8^{3} .1903$.

Cells ovoid to ellipsoid, with a small obtuse projection at each pole. Poles with a whorl of 4-8 long, hyaline, delicately tapering setae at the 
base of the polar projections. Chloroplast single, parietal; with one pyrenoid. (Euplanktont).

Breadth cells (without setae) 8-20 $\mu$; length (without setae) 13-23 $\mu$. Setae 25-35 $\mu$ long.

Horse (rrr), Kegonsa (rrr).

This is the only species with polar projections that resemble the polar nodules of Oocystis.

Lagerheimia Droescheri (Lemmermann) Printz. Pl. 30, Figs. 5-7. Skr. Vidensk. i Kristiania Mat.-Naturv. Kl. 1913', No. 6: 60. 1914.

Chodatella Droescheri Lemmermann, Ber. d. D. Bot. Ges. 18: 98, pl. 3, fig. 12. 1900.

Cells ovoid to ellipsoid; with numerous hyaline delicately tapering setae covering the entire wall. Cells with 2-4 parietal, laminate chloroplasts; each with a single pyrenoid. (Euplanktont).

Breadth of cells (without setae) 5-12 $\mu$; length (without setae) 9-16 $\mu$. Setae 15-22 $\mu$ long.

Horse (rrr), Travis (r), Upper Nashotah (rr).

\section{FRANCEIA Lemmermann 1898.}

Cells ovoid, solitary or in colonies of 2-4; free-floating. Cells enclosed in a delicate gelatinous sheath (?). Entire cell wall covered with delicate hyaline setae that do not taper. Chloroplasts 1-3, parietal, laminate, with or without pyrenoids.

Reproduction by autospores.

Franceis ovalis (Francé) Lemmermann. Pl. 31, Fig. 4. Hedwigia 37: 308. 1898.

Phythelios ovalis Francé, Notarisia 1894: 2, figs. 1-5. 1894.

Cells ovoid to elliptic; with two chloroplasts. (Euplanktont).

Breadth of cells (without setae) 7-10 $\mu$; length (without setae) 13$17 \mu$. Setae $15-23 \mu$ long.

Pine Tree (rr).

The minimal dimensions given above are somewhat smaller than those given by Francé but I feel that the Wisconsin organism should not be considered a distinct variety until the variation in size of the typical form has been determined more fully.

The recognition of the genus Franceia is open to question since the characters upon which Lemmermann bases the genus (number of 
chloroplasts, presence of a vacuole, and cell division in one plane) are ones which might be found in any Lagerheimia species. The setae, however, are very delicate and do not taper so that the genus is provisionally considered distinct from Lagerheimia.

\section{Sub-family SELENASTREAE.}

Cells elongate, straight or curved; with finely pointed ends or with ends rounded. Solitary or associated in colonies containing an indefinite number of cells. Colonies with or without a gelatinous envelope. Cells generally with one parietal chloroplast that is with or without pyrenoids.

Cells solitary.

KEY TO THE GENERA.

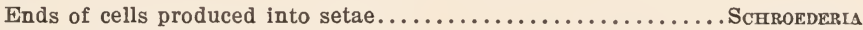

Ends of cells not produced into setae.

Chloroplast with an axial row of pyrenoids...................

Chloroplast never with more than a single pyrenoid.Ankistrodesmus (p. p.) Cells in colonies.

Colonies not enclosed in a gelatinous sheath.

Cells straight, in loose fasiculate bundles or spirally

twisted around one another..................Anxistrodesmus (p.p.)

Cells curved, with convex faces towards one another........ SELENASTRUM Colonies enclosed in a gelatinous sheath.

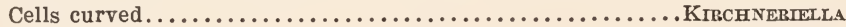

Cells straight.

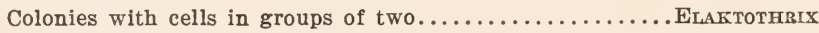

Colonies with cells in groups of $2-4-8 \ldots \ldots \ldots \ldots \ldots \ldots \ldots$ QUADrIGULA

\section{SELENASTRUM Reinsch 1867.}

Cells broadly to narrowly acicular, semilunar; joined by their convex faces into colonies of 4-8-16 or more cells without a gelatinous envelope. Chloroplast single, parietal, laminate, on convex side of young cells; entirely filling older cells; with one pyrenoid.

Reproduction by any cell forming 2-4-8 autospores which, when liberated, have the arrangement of the cells in an adult colony. Autospores remaining attached to parent colony for some time.

The statement is generally made that there are not more than sixteen cells in a colony but I have found that in the plankton of Wisconsin lakes the colonies sometimes contain over a hundred cells. 
KEY TO THE SPECIES.

Cells arcuate, never sickle-shaped............................. Westu

Cells arcuate to sickle-shaped.

Diameter of cells not exceeding $5 \mu \ldots \ldots \ldots \ldots \ldots \ldots \ldots \ldots \ldots$. Gracrle

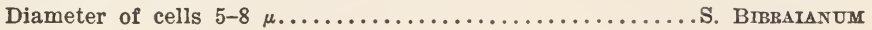

\section{Selenastrum gracile Reinsch. Pl. 31, Fig. 5.}

D. Algenfl. d. mitt. Th. v. Franken 65, pl. 4, figs. 3a-3b. 1867.

Cells lunate to sickle-shaped, quite narrow in proportion to their length. Apices of cells acute. Chloroplast single, laminate, parietal, on convex side of cell. Without a pyrenoid. (Facultative Planktont).

Diam. cells 3-5 $\mu$; length 15-30 $\mu$. Distance between apices 8-20 $\mu$.

Bear (3) (rr), Chain (rr), Hillman (rrr), Horse (rr), Monona (r), Pokegama (1) (rr), Prairie (rr), Upper Turtle (rrr), Whitefish (rr).

Differs from the next species in the more delicate cells. Possibly it should be considered a variety of S. Bibraianum and not a distinct species.

Selenastrum Bibraianum Reinsch. Pl. 31, Figs. 6-7.

D. Algenfl. d. mitt. Th. v. Franken 64, pl. 4, figs. 2a-2b. 1867.

Cells in spherical to ovoid colonies of 4-8-16 or more with their convex sides facing the center of the colony. Cells crescent-shaped to sickle-shaped, gradually tapering to a fairly sharp apex. Chloroplast parietal, on convex side of and almost filling the cell; pyrenoid single. (Facultative Planktont).

Diam. cells 5-8 $\mu$; length 20-38 $\mu$. Distance between apices 5-25 $\mu$.

Beaverdam (rr), Blake (rrr), Bone (rr), Deer (rrr), Little Bass (2) (rrr), Loveless (rr), Mendota (rrr), Meta (r), Nancy (rr), Pewaukee (rr), Pine Tree (rr), Poor Farm (rr), Rice (1) (rr), Spirit (rrr), Squirrel (rrr), Tenderfoot (rr), Travis (rr), White Ash (sss), Wolf (rr).

All descriptions of $S$. Bibraianum state that there are but four or eight cells in the colony but I have found that in Wisconsin lakes there may be over a hundred cells in the colony, the number of cells usually ceasing to be a multiple of two after there are more than sixteen cells in the colony.

Selenastrum Westii sp. nov. Pl. 31, Figs. 8-10.

Selenastrum acuminatum G. S. West non Lagerheim, Jour. of Bot. 50: 88, figs. 5a-5g. 1912.

Colonies of $2-1-8$ cells irregularly arranged with their convex sides in apposition. Frequently dissociating into the individual cells when 
rature. Colls 1!nate to arcuate, never sickle-shaped; gradually tapering to a sharp point. Chloroplast single, parietal on convex side of cell; without a pyrenoid. (Facultative Planktont).

Diam. cells 1.5-2.5 $\mu$. Distance between apices 15-18 $\mu$.

Devils (1) (rr).

The cells of this species are quite like those of Scenedesmus acuminatus (Lagerheim) Chodat but their organization in the colony is quite different. West has recently investigated an organism which he considers identical with the Selenastrum acuminatum deseribed by Lagerheim. I have obtained West's organism in pure culture and find that the cell shape and colony organization is as he describes. The fortunate rediscovery of Lagerheim's species from the plankton of Horse Lake shows that in the organization of the colony it is a Scenedesmus and that Chodat is entirely correct in removing the species from Selenastrum. The organism that West found is, on the other hand, a true Selenastrum but is not the species which Lagerheim erroneously referred to Selenastrum.

\section{ANKISTRODESMUS Corda 1838.}

Cells acicular to fusiform; straight, lunate, or sigmoid; ends of cells gradually tapering to a point; solitary or loosely aggregated without order in temporary colonies that are not embedded in a gelatinous envelope. Chloroplast single, parietal, sometimes fragmented into small pieces; with or without a pyrenoid.

Reproduction by the formation of several autospores in any cell.

\section{KEY TO THE SPECIES.}

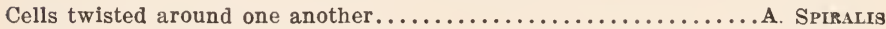

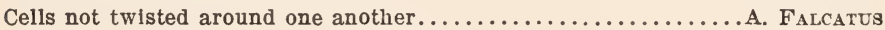

\section{Ankistrodesmus falcatus (Corda) Ralfs. Pl. 32, Fig. 1.}

Brit. Desmidieae 180, pl. 34, figs. 3a-3b. 1848; G. S. West, Brit. Freshw. Algae 223, fig. 94A. 1904 .

Cells acicular to narrowly fusiform, tapering very gradually to acute apices, lunate or slightly arcuate. Length 12-24 times the diameter. Seldom solitary, generally loosely associated in fasiculate bundles. Chloroplast single, generally without pyrenoids. (Facultative Planktont).

Diam. cells 1.5-3.5 $\mu$; length 20-80 $\mu$.

Fence (rrr), Half Moon (rrr), Horse (rr), Kawaguesaga (rrr), Lac du Flambeau (rrr), Little Crooked (rr), Lost (rr), Oconomowoc (rrr), Pine 
Tree (rr), Poor Farm (rr), Poplar (rr), Rock (1) (rr), Tenderfoot (rr), White Ash (rr).

var. ACicularis (A. Braun) G. S. West.

Brit. Freshw. Algae 223, figs. 94B-94c. 1904.

Cells usually solitary, straight or slightly curved, apices acutely attenuated. Chloroplast single, parietal, with or without a pyrenoid.

Cells 2.5-4 $\mu$ broad, 36-65 $\mu$ long.

Beaverdam (rr), Little Bass (1) (rrr), Mendota (rr), Rice (1) (rr), Waubesa ( $r r r)$.

var. tumidus (W. \& G. S. West) G. S. West. Pl. 32, Fig. 2. Brit. Freshw. Algae 224, fig. 94D. 1904.

Cells solitary or in small aggregates, straight or curved, inflated at the middle and with acute apices. Chloroplast single, parietal, with or without pyrenoids. (Tychoplanktont).

Cells 4.5-6.5 $\mu$ broad; 61-73 $\mu$ long.

Devils (1) (rrr), Mendota (rr).

var. mirabilis (W. \& G. S. West) G. S. West. Pl. 32, Figs. 3-5. Brit. Freshw. Algae 224, fig. 94E. 1904.

Cells solitary, straight, lunate, or sigmoid; with acute apices; much longer and narrower than the typical form. Chloroplast single, commonly fragmented by large vacuoles in the cytoplasm; without pyrenoids. (Euplanktont).

Cells $2-3.5 \mu$ broad; up to $150 \mu$ long.

Bear (3) (rr), Bryer (rr), Chain (sss), Crab (rrr), Devils (1) (sss), Devils (2) (rr), Dummy (rr), High (rr), Horseshoe (1) (rr), Reserve (rr), Squirrel (rr), Travis (rrr), Whitefish (rr).

Ankistrodesmus spiralis (Turner) Lemmermann. Pl. 32, Figs. 6-7. Arch. f. Hydrobiol. u. Planktonkde. 4: 176. 1908.

Raphidium spirale Turner, Kgl. Sv. Vet.-Ak. Handl. 25, No. 5: 156, pl. 20, fig. 26. 1892.

Ankistrodesmus falcatus var. spiratis (Turner) G. S. West, Brit. Freshw. Algae 224. 1904.

Cells acicular, attenuated to acute apices; in colonies of four or eight and spirally twisted around one another in the middle of the cell but with the extremities free. Chloroplast single, completely filling the cell; without a pyrenoid (?). (Tychoplanktont). 
Cells $1-2.5 \mu$ broad; $20-40 \mu$ long.

Grassy (rr), Silver (2) (rrr).

G. S. West places the alga as a variety of $A$. falcatus but the twisting of the cell seems to be such a constant character that I have followed Lemmermann's practice in considering it a distinct species.

\section{CLOSTERIOPSIS Lemmermann 1898.}

Cells solitary, acicular, with ends produced into very acute apices, without a gelatinous envelope. Chloroplast single, not interrupted at the center of the cell, occupying the greater portion of the cell and containing a single axial row of about a dozen pyrenoids.

The genus is very closely related to Ankistrodesmus, differing only in the greater length of the cells and the axial row of pyrenoids. It also resembles certain Closterium species but the chloroplast of Closterium is always interrupted at the center of the cell. Many feel that the single species is not sufficiently differentiated to warrant its separation from Ankistrodesmus.

Closteriopsis longissima var. tropica W. \& G. S. West. Pl. 32, Fig. 8. Trans. \& Proc. Bot. Soc. Edinb. 23: 31, pl. 1, fig. 1. 1905.

Rhaphidium longissimum var. tropicum W. \& G. S. West, Trans. Linn. Soc. 2nd. Ser. Bot. 6: 198.1902.

Cells acicular, poles acute but not ending in a point of hair-like fineness. (Facultative Planktont).

Cells 6-7.5 $\mu$ broad; 225-370 $\mu$ long.

North Turtle (rr).

The dimensions of specimens that I have found agree with those given for individuals from Ceylon but not with those from the Scotch plankton.

\section{SCHROEDERIA Lemmermann 1898.}

Cells solitary, straight or curved, acicular; with one apex produced into a fine seta tapering to a point, the other with a slightly broader projection terminating in a small dise. Cells without a gelatinous envelope. Chloroplast single, parietal, laminate; with one pyrenoid.

Method of reproduction unknown. 
Schroederia SETigera (Schröder) Lemmermann. Pl. 32, Fig. 12.

Hedwigia 37: 311. 1898; G. M. Smith, Bull. Torr. Bot. Cl. 43: 473, pl. 24, fig. 8. 1916.

Length of cells 15-20 times breadth. (Euplanktont).

Cells 3-6 $\mu$ broad, 60-85 $\mu$ long (with spines). Length of spines 13-27 $\mu$.

Chain (sss), Devils (1) (c), Long (2) (rr), Sand (1) (rr).

This peculiar alga has the general appearance of a Characium. Although hundreds of individuals have been found, it has never been found attached to other algae or to crustaceans so that it seems safe to assume that it leads a free-floating and not an epiphytic existence. The dise at one end of the setae described above has not been observed by other investigators, possibly because the alga is very minute.

Reproductive stages have never been found so that the systematic position of the genus is doubtful. Judging by the cell shape it is a close relative of Ankistrodesmus, a genus to which it has been referred by some.

Schroederia Judayi G. M. Smith. Pl. 32, Figs. 9-11.

Bull. Torr. Bot. Cl. 43: 474, pl. 24, figs. 9-11. 1916.

Cells smaller than the foregoing. (Euplanktont).

Cells $2.5-6 \mu$ broad, 45-63 $\mu$ long (with spines). Length of spines $10-16 \mu$.

Amicoy (rr), Birch (rrr), Camp (rr), Delavan (rr), Kawaguesaga (rr), Mendota (sss), Prairie (rr), Round (1) (rrr), St. Croix (rr).

\section{QUADRIGULA Printz 1915.}

Cells generally in groups of 2-4-8 with their long axes parallel to the long axis of the colony and enclosed by a hyaline, homogeneous, gelatinous sheath. Colonies ellipsoid, 2-5 times as long as broad. Cells cylindrical to fusiform, 4-7 times as long as broad, straight or slightly curved. Chloroplast single, filling most of the cell; with or without pyrenoids.

Reproduction by 2-4-8 autospores from each cell, the fasiculate group of autospores frequently remaining within the envelope of the mother colony for some time. 
KEY TO THE SPECIES.

Ends of cells rounded................................ Pfitzeri Ends of cells pointed.

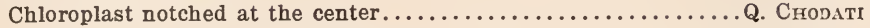

Chloroplast not notched at the center.................. LAcustis

Quadrigula Pfitzeri (Schröder) comb. nov. Pl. 33, Figs. 1-2.

Rhaphidium Pfitzeri Schröder, Verh. d. Nat.-Med. Ver. zu Heidelberg N. F. 7: 152, pl. 6, fig. 6. 1902.

Ankistrodesmus Pfitzeri (Schröde-) G. S. West, Brit. Freshw. Algae 224, figs. 94G-94H. 1904.

Cells about 7 times as long as broad, central portion cylindrical with ends slightly tapering and rounded. Chloroplast generally filling the entire cell, with or without a pyrenoid. (Euplanktont).

Breadth of cells 3-6 $\mu$, length 22-45 (generally about 35) $\mu$.

Bear (1) (rr), Beaverdam (rr), Blake (rr), Chain (rr), Clear (rr), Cochrane (sss), Devils (1) (s), Fishtrap (rrr), Found (r), Fowler (rr), Harris (rr), Hillman (ss), Jennie (rr), Lac Court Oreilles (rr), Lindy (rr), Long (2) (rrr), Little Wood (rr), Mud (1) (rr), Mudhen (rr), Oconomowoc (rr), Okauchee (rr), Palmer (sss), Pardee (rr), Pine Tree (r), Poplar (r), Reserve (rr), Rice (1) (rr), Sand (1) (rr), Shell (rr), Sishebogema (rr), Travis (rr), White Ash (r), Whitefish (rr), Wild Goose (rrr).

The chief characteristic of the genus is the arrangement of the cells in groups of 2-4-8 with their long axes parallel to the long axis of the colony, together with the gelatinous envelope that surrounds the colony. Admitting the generic validity of Quadrigula, Ankistrodesmus Chodati and $A$. lacustris are in a much more natural position when placed with Quadrigula species.

Quadrigula Chodati (Tanner-Fullman) comb. nov. Pl. 33, Fig. 3.

Raphidium Chodati Tanner-Fullman, Bull. Herb. Boiss. 2 Ser. 6: 156, figs. 1-11. 1906.

Ankistrodesmus Chodati (Tanner-Fullman) Brunnthaler, in Pascher, Süsswasserfl. Deutschl., österr. u. d. Schw. 5²: 193, fig. 306. 1915.

Cells linear, arcuate, or lunate; fusiform and tapering to sharp ends. Longitudinally arranged in a gelatinous colony of 4-8-16 or more cells. Cells with a single, parietal, laminate chloroplast that is notched at the center and contains two pyrenoids. (Euplanktont).

Breadth of cells $3.5-7 \mu$, length $30-80 \mu$. Colonies up to $50 \times 250 \mu$.

Boulder (r), Little Bass (2) (rrr), Lac du Flambeau (rr), Sand (3) (ss).

Tanner-Fullman states that the cells are always lunate but those that I have observed were always straight or slightly curved. The notching of the chloroplast together with the two pyrenoids is such a distinct 
feature that there can be no doubt of the identity of the Wisconsin alga with his species.

Quadrigula lacustris (Chodat) comb. nov. Pl. 33, Figs. 4-6.

Raphidium Braunii var. lacustre Chodat, Bull. Herb. Boiss. 5: pl. 11, figs. 9-10. 1897; Matér. pour la fl. crypt. Suisse 13: 200, fig. 117. 1902.

Ankistrodesmus lacustre (Chodat) Ostenfeld, Hedwigia 46: 384. 1907.

Cells spindle-shaped, straight, with pointed ends. Cells rarely solitary, generally irregularly distributed throughout, or in groups with their long axes parallel to the long axis of the fusiform gelatinous colonial envelope. Chloroplast single, parietal, laminate, at one side of the cell or spirally twisted; generally with a single pyrenoid. (Euplanktont).

Cells $3-5 \mu$ broad, 20-25 $\mu$ long.

Blue Gill (rr), Browns (rr), Clear Crooked (cc), Green (2) (rr), Horseshoe (1) (rr), Lynx (rr), Pokegama (2) (rr), Round (1) (rrr).

\section{ELAKTOTHRIX Wille 1898.}

Cells fusiform when mature, longitudinally arranged in pairs within a fusiform homogeneous gelatinous matrix. Chloroplast single, laminate, parietal, with one or two pyrenoids. Colonies epiphytic when young and free-floating when mature; or free-floating throughout the life of the plant.

Reproduction by a transverse division into two daughter cells which remain unchanged for some time. Akinetes known.

Wille first placed the alga as a close relative of Actinastrum Hantzschi Lagerheim, but later thought it a relative of Coccomyxa Schmidle (Wille, in Engler \& Prantl, Nat. Pflanzenfam. $1^{2}$ (Nachtr.) : 36, figs. 18A-18E. 1909) ; Pascher (Susswasserfl. Deutschl., Osterr. u. d. Schw. $5^{2}$ : 220, figs. 25-26. 1915) places it among the algae of doubtful systematic position; while G. S. West (Algae 1: 202. 1916) thinks it closely allied to Ankistrodesmus, a view which seems to me most logical since Ankistrodesmus, Quadrigula and Elaktothrix form a very natural evolutionary series.

KEY TO THE SPECIES.

Both poles of cells acute............................. Viridis One pole of cell acute, the other generally rounded............. GeLAtivosa

\section{Elaktothrix gelatinosa Wille. Pl. 34, Figs. 1-3.}

Biol. Cent. 18: 302. 1898; in Engler \& Prantl, Nat. Pflanzenfam. 1' (Nachtr.): 36, figs. 18A-18E. 1909; W. \& G. S. West, The Naturalist, 1909: 291, figs. 6A-6D. 1909.

Colonies free-floating, elongate fusiform to somewhat irregular; with 
the long axes of the cells parallel to the long axis of the colony. Cells lying in pairs, spindle-shaped; generally with one pole rounded and the other pointed. The rounded ends of a pair of cells in apposition. Chloroplast single, parietal, laminate; with one pyrenoid. Colonies rarely containing over fifty cells. (Euplanktont).

Cells 3-6 $\mu$ broad; 15-25 $\mu$ long. Colonies 10-30 $\mu$ broad; 70-160 $\mu$ long.

Crooked (rrr), Deer (rrr), Hillman (rr), Jag (rrr), Jennie (rr), Long (2) (rrr), Long (3) (rr), Loon (rrr), Mudhen (rr), Pine (2) (rrr), Sand (2) (rrr), Streitor (sss).

The dimensions of the cells and the general appearance of the colony in individuals that I have found is more like the Wests' description of the alga as found in England. Wisconsin colonies rarely contain more than sixteen cells.

Elaktothrix viridis (Snow) Printz. Pl. 33, Fig. 7.

Skr. Vidensk. i Kristiania Mat.-Naturv. Kl. 1913' ${ }^{1}$ No. 6: 31, pl. 1, figs. 9-12. 1914.

Fusola viridis Snow, Bull. U. S. Fish Comm. 22: 389, pl. 2, figs. VI²-VI 1903.

Colony free-floating or epiphytic, fusiform or irregular; gelatinous sheath of colony sharply defined, frequently showing remains of old cell wall at apex. Cells broadly fusiform, straight or sigmoid, with acute apices. Chloroplast single, completely filling the cell; with one or two pyrenoids. (Tychoplanktont).

Cells 6-15 $\mu$ broad, 12-35 $\mu$ long.

Soft (rr).

\section{KIRCHNERIELLA Schmidle 1893.}

Cells lunate to sickle-shaped with their apices almost touching; or elongate, vermiform, arcuate, or spiral cylinders with rounded ends. Associated without definite arrangement in colonies enclosed by a hyaline, homogeneous, gelatinous envelope. Number of cells in young colonies a multiple of two, in older colonies indefinite but rarely more than seventy-five. Chloroplast single, parietal, on convex side of or entirely filling the cell; generally with a single pyrenoid.

Reproduction by the division of any cell to form four or eight autospores that are liberated by a rupture of the old mother cell wall but remain within the gelatinous envelope of the colony. 


\section{KEY TO THE SPECIES.}

Cells lunate to sickle-shaped.

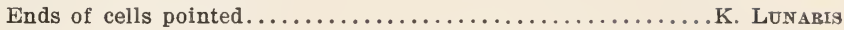

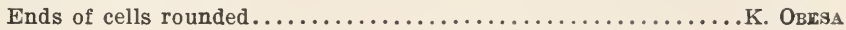

Cells arcuate, spiral, or vermiform cylinders.

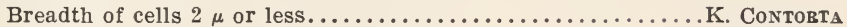

Breadth of cells over $2 \mu \ldots \ldots \ldots \ldots \ldots \ldots \ldots \ldots \ldots \ldots \ldots \ldots \ldots \ldots \ldots \ldots \ldots$. Elongata

\section{Kirchneriella lunaris (Kirchner) Möbius. Pl. 34, Fig. 4.}

Abh. d. Senckenb. Naturf. Ges. 18: 331. 1894; Chodat, Matér. pour la fl. crypt. Suisse $1^{3}$ : 202, figs. $121^{1}-121^{6}$. 1902.

Cells flattened, crescent-shaped, with apices some distance apart, about twice as long as broad, ends tapering to a blunt point; irregularly arranged in groups of four to eight within the gelatinous colonial envelope. Chloroplast single, filling the entire cell with the exception of a small part on the concave side; pyrenoid single. (Facultative Planktont).

Cells $3-8 \mu$ broad, $6-15 \mu$ long; colonies up to $250 \mu$ in diam.

Bear (3) (rr), Beaverdam (rr), Birch Island (rrr), Blake (rr), Chain (ss), Chetek (rr), Cochrane (rr), Crab (rrr), Deer (rr), Devils (2) (rr), Duck (rr), Dummy (sss), Elizabeth (rr), Green (2) (rr), High (rr), Hillman (r), Hurseshoe (1) (rr), Jag (rr), Lindy (rrr), Little Crooked (rrr), Little Doctor (rr), Long (3) (rrr), Loveless (rr), Lower Turtle (rrr), Lynx (rrr), Mendota (rr), Meta (rr), Mud (2) (rr), Nancy (sss), North Twin (rrr), Paddock (rr), Pardee (rr), Pine Tree (rr), Pokegama (1) (r), Pokegama (3) (sss), Poplar (rr), Prairie (sss), Round (3) (rrr), St. Croix (r), Shell (r), Spirit (rrr), Squirrel (rr), Upper Turtle (rrr), White Ash (rr).

The species differ from $K$. obesa in the pointed ends of the cells. The two are widely distributed plankton .organisms but have never been found in quantity in any lake of the state.

var. Dianae Bohlin. Pl. 34, Fig. 5.

Bih. Kgl. Sv. Vet.-Ak. Handl. 23, Afd. 3, No. 7: 20, pl. 1, figs. 28-30. 1897.

Cells curved until the apices are almost touching, apices more pointed and frequently slightly twisted. (Facultative Planktont).

Cells 3-5 $\mu$ broad, 10-21 $\mu$ long.

Hillman (rr), Pine (2) (rr), White Ash (r).

The cell shape of this variety resembles that of Selenastrum but the colony differs in being enclosed by a gelatinous envelope. The apices are much sharper than in the typical form. 
var. irregularis var. nov. Pl. 35, Fig. 1.

Apices of cells twisted and frequently not pointing in the same direction. (Facultative Planktont).

Cells 4-6 $\mu$ broad, 6-13 $\mu$ long.

Cochrane (rr), Pokegama (1) (r), Tenderfoot (rr).

Although the cell apices of $K$. lunaris var. dianae are sometimes not in the same plane, they never exhibit the twisting found in this variety. The twisting of the cells of this variety is similar to that of $K$. contorta but they have the shape and pointed ends that characterize $K$. lunaris.

Kirchneriella obeSa (W. West) Schmidle. Pl. 35, Figs. 2-3.

Ber. d. Naturf. Ges. zu Freiburg i. B. 7: 16 (83). 1893; G. S. West, Brit. Freshw. Algae 226, figs. 96A-96E. 1904.

Cells flattened with outer side markedly convex and inner sides parallel, ends rounded and tapering slightly. Chloroplast single, filling the entire cell with the exception of a small portion on the concave side; with one pyrenoid. (Facultative Planktont).

Cells 3-8 $\mu$ broad, 6-16 $\mu$ long.

Bear (2) (rr), Bear Trap (rr), Camp (rr), Catherine (rr), Center (r), Chain (rr), Chetac (r), Crawling Stone (rrr), Devils (1) (rrr), Hillman (rr), Kitten (rr), Lac Court Oreilles (ss), Lac du Flambeau (rr), Mendota (r), Palmer (rrr), Pine Tree (rr), Pokegama (2) (rr), Poor Farm (rr), Reserve (rr), Rice (1) (rr), Rock (rrr), Sand (4) (rr), South Turtle (rr), Whitefish ( $r r r)$, Wildcat ( $r r)$, Winnebago ( $r r)$.

The cells of this species might be described as thick discs incised a third to a half the width of the cell did not other members of the genus show that this effect is produced by a curving of the cell.

var. MAJOR (Bernard) G. M. Smith. Pl. 35, Fig. 4.

Trans. Wis. Acad. Scl., Arts, \& Lett. 19 ${ }^{1}: 636, p l$. 10, fig. 7. 1918.

Inner face between cell apices curved; apices not close together, rounded and slightly tapering. (Facultative Planktont).

Cells $3-5 \mu$ broad, 8-21 $\mu$ long.

Carson (rr), Lac Court Oreilles (r), Wolf (rr).

This variety has a large open space between the apices whereas in the typical form this space is narrow and with parallel sides. The cells are also much narrower in proportion to their length. Brunnthaler (in Pascher, Süsswasserfl. Deutschl. Osterr. u. d. Schw. 5² : 180. 1915) has placed the alga as a form of $K$. lunaris var. dianae but the cell apices are too rounded to consider it a variety of $K$. lunaris. 
var. APERTA (Teiling) Brunnthaler. Pl. 35, Figs. 5-6.

in Pascher, Süsswasserfl. Deutschl. österr. u. d. Schw. 5²: 182, fig. 268. 1915. Kirchneriella aperta Teiling, Sv. Bot. Tids. 6: 276, fig. 9. 1912.

Cells with blunt, rounded apices, concave side between apices broadly V-shaped. (Facultative Planktont).

Diam. cells 6-12 $\mu$.

Diamond (rr), Palmer (ss).

Kirchneriella contorta (Schmidle) Bohlin. Pl. 35, Fig. 7.

Bih. Kgl. Sv. Vet.-Ak. Handl. 23, Afd. 3, No. 7: 20.1897.

Kirchneriella obesa var. contorta Schmidle, Flora 78: 44, pl. 7, fig. 2. 1894.

Cells cylindrical, arcuate or in spirals that never make more than $11 / 2$ turns; ends rounded, not tapering. Cells generally lying some distance from one another within the homogeneous colonial envelope. Chloroplast single, filling the entire cell, without a pyrenoid. Cells sometimes spirally arranged in the colony; rarely more than sixteen cells in a colony. (Facultative Planktont).

Cells $0.7-2.0 \mu$ broad, 8-14 $\mu$ long; colonies up to $60 \mu$ in diam.

Chain (rrr), Clear (rr), Cochrane (rr), Fowler (rrr), Mendota (rrr), Pardee (rr), Pine Tree (rrr), Poor Farm (rrr).

A species which at first glance does not appear related to $K$. lunaris and $K$. obesa, but which at times shows a certain resemblance to $K$. obesa var. major. It and the following species are rare algae in Wisconsin. They are closely related, the chief difference being the smaller size and fewer number of cells in the colony of $K$. contorta.

Kirchnerteila elongata G. M. Smith. Pl. 36, Figs. 1-2.

Bull. Torr. Bot. Cl. 43: 473, pl. 24, fig. 7. 1916.

Cells elongate-cylindrical with rounded ends; spirally or irregularly twisted. Colonies of 4-8-16 or more cells arranged in a snarl at the center of a copious homogeneous gelatinous sheath. Chloroplast single, parietal; without a pyrenoid. (Facultative Planktont).

Cells $2-3 \mu$ broad, $15-25 \mu$ long; colonies up to $100 \mu$ in diam.

Devils (2) (rrr), Horse (rrr), Lac Court Oreilles (rr), No Mans (rr), Palmer (rr), White Ash (sss).

\section{Sub-family CRUCIGENIEAE.}

Cells acicular, fusiform, ovoid, triangular, or trapezoidal; in flat coenobia with the number of cells always a multiple of two. Cells quadrately arranged in coenobe or in a linear series. Coenobe generally without a gelatinous envelope. Chloroplasts 1-4, parietal, disciform or laminate; generally with one pyrenoid. 


\section{KEY TO THE GENERA.}

Cells quadrately arranged.

Quadrate arrangement apparent in front view of cells.

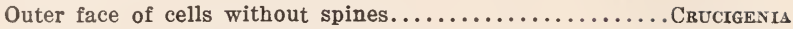

Outer face of cells with spines.................... Tetrastrum

Quadrate arrangement apparent in end view of cells........TETRADESMUS

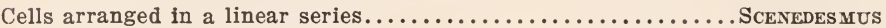

\section{CRUCIGENIA Morren 1830.}

Coenobe free-swimming, of four cells quadrately arranged with a quadrangular open space at the center and frequently connected to other coenobia by a gelatinous envelope or the remains of the old mother cell walls. Multiple coenobia forming a flat plate one cell in thickness and containing 4, 16, 32, 64 or more cells. Cells flattened; ovoid, triangular, trapezoidal, or semicircular in front view; with a smooth cell wall. Chloroplasts 1-4, parietal, disciform to laminate, with or without pyrenoids.

Reproduction by autocolony formation, the four cells of the coenobe generally producing autocolonies at the same time.

KEY TO THE SPECIES.

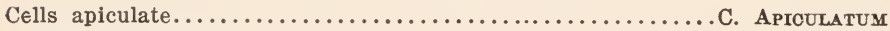
Cells not apiculate.

Coenobe with a large rectangular open space at the center.

Front view of cells trapezoidal.................... Fenestrata

Front view of cells semicircular.................. LAUTERBornet

Coenobe with a small open space at the center.

Length of coenobe greater than the breadth.

Wall of cell the same thickness throughout.

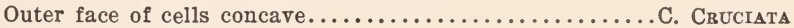

Outer face of cells convex.

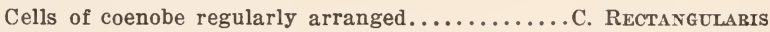

Cells of coenobe irregularly arranged............. IRrEgULARIS

Wall of cell thicker at the poles................... Truncata

Length of coenobe the same as the breadth.

Cells triangular, with fairly acute corners............. TETRAPEDIA

Cells spherical to triangular, with rounded corners......... QUADRATA

Crucigenia rectangularis (Nägeli) Gay. Pl. 36, Fig. 3.

Recherches sur le. dév. et la class. de quelques algues vertes $100, p l .15, f g .151$. 1891.

Coenobe four-celled, cells in mutual contact at the poles and sides and with a small rectangular open space at the center. Generally united in compound coenobia containing an indefinite number of coen- 
obes. Cells ovoid to elongate-ovoid, with 1-4 parietal, disciform chloroplasts, each with a single pyrenoid. Old mother cell wall frequently enclosing young coenobia for some time. (Facultative Planktont).

Cells 4-7 $\mu$ broad, 5-10 $\mu$ long.

Bear (2) (rr), Beaverdam (rr), Big (rrr), Birch Island (rrr), Devils (1) (r), Fowler (rrr), Half Moon (rr), Hillman (rr), Kegonsa (rr), Lac Court Oreilles (rr), Lindy (rr), Little Bass (2) (rr), Little Doctor (rr), Mill (rrr), Nancy (rr), Nicaboyne (rr), Okauchee (rrr), Old Taylors (rr), Pine Tree (rr), Sand (1) (rr), Upper Nashotah (rrr), Winnebago (rr).

\section{Crucigenia irregularis Wille. Pl. 36, Figs. 4-5.}

Biol. Cent. 18: 302. 1898; Nyt. Mag. f. Naturvidensk. 38: 10, pl. 1, fig. 15, 1900; W. \& G. S. West Trans. \& Proc. Bot. Soc. Edinburgh 23: 29, pl. 1, figs. 6-7. 1905.

Coenobia four-celled, with cells in contact at sides and poles, at other times without a definite arrangement. Coenobia irregularly combined into multiple coenobia. Cells ovoid; with 1-4 parietal, disciform chloroplasts; with or without pyrenoids. (Facultative Planktont).

Cells $4-9 \mu$ broad, 6-14 $\mu$ long. Coenobia 8-14 $\mu$ broad, 15-30 $\mu$ long.

Browns (rr), Camp (rr), Fish (rr), Horseshoe (2) (rr), Mudhen (rr), Reserve (rr), Sand (3) (sss).

The cell shape is quite similar to that of $C$. rectangularis but the arrangement of cells within the coenobe is very irregular in about half the colonies one meets with. This irregular cellular arrangement coupled with the larger cell size warrants the separation of the alga from C. rectangularis. The alga is generally reported to be without pyrenoids but I have frequently found them in the chloroplasts of $C$. irreguharis.

Crucigenia crucifera (Wolle) Collins. Pl. 36, Fig. 6.

Tufts. coll. studies 2: 170. 1909.

Staurogenia crucifera Wolle, Bull. Torr. Bot. Cl. 6: 140. 1877.

Staurogenia cruciatum Wolle, Freshw. Algae of U. S. 171, pl. 157, figs. 9-11. 1887.

Coenobia four-celled, rhomboidal, with rounded ends, slightly concave sides, and a small rectangular open space at the center. Cells elongate, outer face concave, inner and those in contact with other cells straight. Chloroplast single, parietal, laminate; without a pyrenoid. (Facultative Planktont).

Cells 3.5-5 $\mu$ broad, 5-7 $\mu$ long. Coenobia 9-11 $\mu$ broad, 14-16 $\mu$ long. Hillman ( $\mathrm{rr}$ ), Tenderfoot ( $\mathrm{rr}$ ).

The arrangement of the individual coenobia into compound coenobia is generally that which Wolle gives in his figure 9 of Staurogenia cruci- 
atum. Collin's surmise that the reported cruciform marking of the cell wall is probably due to a division of the cell contents is correct and what Wolle calls the cell is in reality the coenobe. The remains of the old cell walls play an important part in binding together the various coenobia of the multiple coenobe.

Crucigenia truncata sp. nov. Pl. 36, Figs. 7-9.

Coenobe four-celled, with a small rectangular space at the center and held in compound coenobia of indefinite size by the remains of old mother cell walls. Cells quadrately arranged with bases and middle third of inner sides in mutual contact but with apices and outer faces free. Cells elongate, ovoid, with free ends truncate. Cell wall at free apex thicker than in other parts. Chloroplasts 1-4, parietal, disciform, without pyrenoids. (Euplanktont).

Cells 4-6 $\mu$ broad, 6-10 $\mu$ long. Coenobia 6-12 $\mu$ broad, 12-20 $\mu$ long. Compound coenobia up to $50 \times 75 \mu$.

Chain (rr), Hillman (rr), Pine Tree (rr), Travis (rr).

The species is differentiated by its flattened cell apices and the thicker walls at the apices. The cells are always regularly arranged within the coenobe, but when in compound coenobia the arrangement is frequently irregular.

Crucigenia apiculata (Lemmermann) Schmidle. Pl. 37, Fig. 1. Allg. Bot. Zeitschr. 6: 234. 1900.

Staurogenia apiculata Lemmermann, Bot. Cent. 76: 151.1898 ; Forschungsbr. a. d. Biol. Stat. zu Plön 7: 119, pl. 1, fig. 14. 1899; Snow, Bull. U. S. Fish Comm. 22: 376, pl. 1, figs. V'-Vs. 1903.

Tetrastrum apiculatum (Lemmermann) Brunnthaler, in Pascher, Süsswasserfl. Deutschl., österr. u. d. Schw. 5²: 177, fig. 258. 1915; G. M. Smith, Bull. Torr. Bot. Cl. 43: 472, pl. 24, fig. 3. 1916.

Coenobia four-celled, embedded in a delicate gelatinous sheath. Cells quadrately arranged with their long axes parallel and a small rectangular space at the center. Coenobia generally in multiple coenobia which, when containing large numbers of coenobia, are frequently irregular. Cells ovoid to triangular, with a short conical projection at the free apex and frequently another one at the side of the base away from the center of the coenobe. Each cell containing 1-4 parietal disciform chloroplasts with one pyrenoid. (Euplanktont).

Cells 3-7 $\mu$ broad, 5-10 $\mu$ long. Coenobia 6-12.5 $\mu$ broad, 9-18 $\mu$ long. Compound coenobia up to $150 \mu$ broad.

Mendota (rrr), Palmer (rrr), South Crab (rr).

The cells of 16-celled multiple coenobia are regularly arranged but when multiple coenobia contain 150-200 cells the arrangement is fre- 
quently irregular. The gelatinous sheath enclosing the colony is very delicate and can only be seen when properly stained. This species was placed in the genus Tetrastrum in a preliminary list, but it is more closely related to Crucigenia than to Tetrastrum.

\section{Crucigenia quadrata Morren. Pl. 36, Figs. 10-14.}

Ann. Sci. Nat. 20: 415, pl. 15, figs. 1-5. 1830.

Staurogenia triangularis Chodat, Mém. Herb. Boiss. 1, No. 17 : 7, figs. 14-19. 1900.

Crucigenia triangularis (Chodat) Schmidle, Allg. Bot. Zeitschr. 6: 234. 1900.

Staurogenia multiseta var. punctata Schmidle, Ber. d. D. bot. Ges. 18: 157, pl. 6, figs. 13-14. 1900.

Coenobia four-celled, circular in outline. Cells in mutual contact at or with very small rectangular openings at center of the coenobe. Four coenobia compressed to form rectangular multiple coenobia which in turn are joined to other sixteen-celled multiple coenobia. Cells spherical to triangular; with a smooth wall or with 1-6 minute knoblike projections on the wall. Chloroplasts 1-4, parietal, disciform, with or without pyrenoids. (Facultative Planktont).

Cells 2.5-6 $\mu$ broad, 3-7 $\mu$ long. Coenobia 5.5-17 $\mu$ in diam. 16celled compound coenobia $12-30 \mu$ in diam.

Carson (rrr), Chain (rr), Hillman (sss), Kitten (rrr), Lac du Flambeau (rr), Palmer (sss), Pardee (rr), Tenderfoot (rrr), White Sand (rrr).

Pyrenoids are very prominent in the chloroplasts of certain colonies while other colonies collected from the same station show no trace of them. In some of the colonies from Hillman lake small, globular, button-like structures were observed on the cell walls. Such structures have been noted by Schmidle and form the distinctive character of his variety punctata of Staurogenia multiseta [Tetraslrum multisetum (Schmidle) Chodat]. If the variety is to be recognized it should be called C. quadrata var. punctata (Schmidle) but I am of the opinion that it is not a sufficiently constant character to warrant recognition. There is likewise no justification for considering $C$. triangularis (Chodat) Schmidle a distinct species since it does not differ in any respect from C. quadrata.

Crucigenia tetrapedia (Kirchner) W. \& G. S. West. Pl. 37, Fig. 2.

Trans. Roy. Irish Acad. 32, Sec. B: 62, pl. 1, figs. 11-12. 1902.

Staurogenia tetrapedia Kirchner, Jahreshefte d. Ver. f. Vaterl. Naturk. 1. Württemberg 1880, pl. 2, fig. 1.

Tetrapedia emarginata Schröder, Ber. d. D. bot. Ges. 15: 492, pl. 25, figs. 6a-6c. 1897.

Lemmermannia emarginata (Schröder) Chodat, Mém. Herb. Boiss. 1, No. 17; 5, figs. 1-8. 1900. 
Lemmermannia tetrapedia (Kirchner) Lemmermann, Arkiv. för Botanik 2 , No. 2: 157. 1904.

Coenobia four-celled, with a very small rectangular open space at the center. Frequently joined in multiple coenobia of sixteen cells that may be connected in turn to other 16-celled multiple coenobia. Cells flattened, triangular, with rounded corners. Cell contents homogeneous, or with a single parietal chloroplast, with or without pyrenoids. (Facultative Planktont).

Diam. cells 4.8-9.5 $\mu$; diam. coenobia 8-15 $\mu$; diam. 16-celled multiple coenobia up to $40 \mu$.

Palmer (rr).

Certain investigators have noted that the cell contents are at times absolutely homogeneous. This has caused Schröder to consider the alga a species of Tetrapedia, one of the Myxophyceae, but the Wests have given cogent reasons for considering it a Crucigenia. I have found a distinct parietal chloroplast and pyrenoid in the cells whereas Chodat states that there is a chloroplast but no pyrenoid. His founding of the genus Lemmermannia upon this single character (lack of a pyrenoid) has rightly been called by G. S. West (Brit. Freshw. Algae 217. 1904) "the climax of absurdity."

\section{Crucigenia fenestrata Schmidle. Pl. 37, Fig. 3.}

Allg. Bot. Zeitschr. 6: 234. 1900.

Staurogenia fenestrata Schmidle, Allg. Bot. Zeitschr. 3: 107, fig. 1. 1897.

Coenobia four-celled, rectangular, with a medium-sized opening at the center; with an inconspicuous gelatinous sheath. Frequently in multiple coenobia with the component coenobia lying close together. Cells trapezoidal, with the longest face at the outside of the coenobe. Chloroplast single, except just before division, parietal, without a pyrenoid (?). (Euplanktont).

Cells $3-5 \mu$ broad, 5-12 $\mu$ long; coenobia 8-14 $\mu$ broad.

Bettine (rr), White Sand (rr).

The specimens that I have found do not agree in all respects with Schmidle's description since there was no gelatinous sheath surrounding the coenobe and filling the central space.

Crucigenia Lauterbornei Schmidle. Pl. 37, Fig. 4.

Allg. Bot. Zeitschr. 6: 234. 1900.

Staurogenia Lauterbornei Schmidle, Allg. Bot. Zeitschr. 2: 192, fig. 1. 1896.

Coenobia four-celled, cells in contact with one another at their apices only and with a large square open space at the center of the coenobe. 
Coenobia joined in multiple coenobia of at least sixteen cells by the remains of old cell walls and a gelatinous envelope. Cells flattened, subhemispherical in front view with the flattened side towards the center of the coenobe. Chloroplast single, parietal, on the outer face of the cell; with one pyrenoid. (Euplanktont).

Cells 4.5-9 $\mu$ broad, 8-15 $\mu$ long. Coenobia 15-25 $\mu$ in diam; multiple coenobia up to $150 \mu$ in diam.

Kegonsa (r), Pokegama (rr), Rice (1) (r), Upper Turtle (r).

A very distinct species and one that is readily recognized by the large opening at the center of the colony. C. fenestrata also has a large, rectangular open space at the center of the coenobe but the two species have quite differently shaped cells; those of $C$. Lauterbornei being semicircular in front view, and those of $C$. fenestrata trapezoidal.

\section{TETRASTRUM Chodat 1895.}

Coenobia four-celled, with cells cruciately arranged in a flat plate; at times embedded in a thin gelatinous envelope. Cells triangular to ovoid, with several spines or setae on the free face. Chloroplasts 1-4, parietal, disciform, with or without pyrenoids.

Reproduction by autocolony formation in any cell.

The genus is closely related to Crucigenia, differing only in the spines on the margins of the cells and an absence of an association in multiple coenobia.

Tetrastrum staurogeniaeforme (Schröder) Lemmermann. Pl. 37, Figs. 5-6.

Ber. d. D. bot. Ges. 18: 95.1900.

Cohniella Staurogeniaeformis Schröder, Ber. d. D. bot. Ges. 15: 373, $p l .17$, fig. 5. 1897.

Coenobia four-celled, with a very minute open space at the center of the colony. Coenobe embedded in a very delicate gelatinous envelope. Cells cruciately arranged, triangular, with 5-6 very delicate setae on the free surface. Chloroplasts 1-4, parietal, disciform, with or without pyrenoids. (Euplanktont).

Diam. cells (without setae) 3-6 $\mu$; diam. coenobia (without setae) 7-15 $\mu$. Setae $4-8 \mu$ long.

Horse (rr), Mendota (rrr).

The setae on the outer face of the cells are very delicate and easily overlooked. If the setae are not taken into consideration the alga looks exactly like Crucigenia quadrata. 


\section{TETRADESMUS G. M. Smith 1913.}

Colonies free-floating, four-celled, rarely two- or three-celled. Cells in two planes with two cells in each plane and joined along the long axes when the colony is viewed from the side. Viewed from the top cclls quadrately arranged. Cells elliptic-fusiform to broadly elliptic, with outwardly divergent or straight apices. Chloroplast single, parietal and laminate or completely filling the cell; pyrenoid single, central or eccentric.

Reproduction by autocolony formation in any cell of the colony, the young coenobia being liberated by a rupture of the mother cell wall.

Tetradesmus wisconsinensis G. M. Smith. Pl. 37, Figs. 7-11. Bull. Torr. Bot. Cl. 40: 76, pl. 1, figs. 1-2, 3-20. 1913.

Cells elliptic-fusiform, apices attenuated and outwardly divergent. Pyrenoids eccentric. (Facultative Planktont).

Cells 4-6 $\mu$ broad, 12-14.5 $\mu$ long.

Blake (rrr), Mendota (rr), Nancy (rrr).

\section{SCENEDESMUS Meyen 1829.}

Coenobe a flat (rarely curved) plate of ellipsoidal, ovoid, or acicular cells with cell number always a multiple of two. Cells in lateral contact and in one or two rows. Cell wall smooth, corrugated, granulate, or spicate; with or without marginal or lateral teeth or spines. Chloroplast single, parietal, and laminate in young cells; frequently filling entire cell in older colonies; pyrenoids single, central or eccentric.

Reproduction by autocolonies from any or all cells of the coenobe, the number of cells in the colony not necessarily the same as that of the mother colony.

\section{KEY TO THE SPECIES.}

Walls smooth, without granulations, lateral ridges, terminal teeth or spines.

Cells acicular to broadly elliptic, with pointed ends.

Colony a flat plate.

All cells in colony erect.

S. OBLiquUs

Median cells erect, terminal cells lunate............... DimorpHus

Colony a curved or twisted plate.

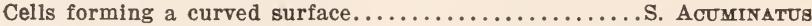

Cells alternately arranged with terminal cells not in the

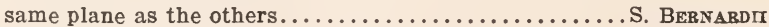

Cells ovoid to cylindrical, with rounded ends.

Arrangement of cells a single linear or subalternating but

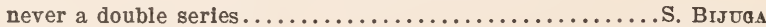

Arrangement of cells a double linear series................ ARcuatus 
Wall variously sculptured or ridged, at times with terminal teeth or spines.

Longitudinal ridges on sides of the cells.

Without terminal teeth or spines.

S. Acutrioracis

With terminal teeth or spines.

Terminal cells with long spines at poles................. Aвмatus

All cells with short teeth at poles.................. BrasiLnensis

Longitudinal ridges not present on sides of the cells.

Teeth-like spines covering entire wall.

.S. Hrstbrx

Teeth or spines confined to poles, outer face of terminal

cells, or middle of all cells.

Cells with short teeth at poles.

S. Dentroulatus

Cells with long spines.

Spines on both median and terminal cells.

Poles of cells only region bearing spines.

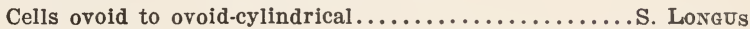

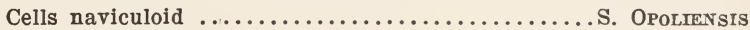

Poles and median part of cells bearing spines.......... S. ABUNDANs

Spines confined to terminal cells.

Cells ovoid to ovoid-cylindrical................. QuAdricaUdA

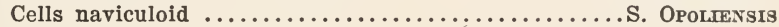

Scenedesmus obliquUs (Turpin) Kützing. Pl. 37, Figs. 12-14.

Linnaea 8: 609. 1833; G. S. West, Brit. Freshw. Algae 220, fig. 92A. 1904.

Cells of 2-4-8 cells arranged in a single linear or sublinear series. Cells fusiform, with acute apices; interior cells with straight sides, outer face of terminal cells slightly concave, straight, or convex. Cell wall smooth, without terminal teeth or spines. (Tychoplanktont).

Cells 3-9 $\mu$ broad, 10-21 $\mu$ long. 4-celled coenobia 10-21 $\mu$ broad, 12.5-24 $\mu$ long.

Balsam (rrr), Bear (1) (rrr), Blake (rr), Bone (rr), Grassy (rr), Hillman (rrr), Horseshoe (2) (rrr), Lindy (rr), Little Bear (rrr), Little Doctor (rr), Little Rice (2) (rrr), Loon (rr), Mendota (rrr), Pewaukee (rrr), Poor Farm (rrr), Pope (rrr), Rice (2) (rr), Sand (3) (rrr), Sand (4) (rrr), Upper Nemahbin (rrr), White Ash (rrr).

Scenedesmus dimorphus (Turpin) Kützing. Pl. 37, Figs. 15-17.

Linnaea 8: 608. 1833; G. M. Smith, Trans. Wis. Acad. Sci., Arts, \& Lett. 18² 434, pl. 32, figs. 185-189; pl. 33, figs. 190-195. 1916.

Coenobia of four or eight cells arranged in a linear or alternating series. Cells fusiform with apices attenuated to delicate points. Interior cells erect, outer erect or markedly lunate. Cell wall smooth, without terminal teeth or spines. (Facultative Planktont).

Cells 2-5 $\mu$ broad, 18-23 $\mu$ long. 4-celled coenobia 18-23 $\mu$ broad, 12-25 $\mu$ long.

Dunham (rrr), Horse (r), Pine Tree (sss), Poor Farm (ss), Travis (sss). 
The outwardly turned lunate terminal cells, together with the pronounced alternate arrangement distinguishes this species from the foregoing. I have given elsewhere (1. c.) the reasons for considering this a distinct species and not a variety of S. obliquus.

Scenedesmus acuminatus (Lagerheìm) Chodat. Pl. 38, Figs. 1-4.

Matér. pour la fl. crypt. Suisse 133: 211. 1902.

Selenastrum acuminatum Lagerheim öfvers. Kgl. Vet.-Ak. Förh. 39: No. 2: 71, pl. 3, figs. 27-30. 1882 .

Coenobia curved, of 4 or 8 (generally 4 ) cells. All of the cells of a colony areuate or lunate, fusiform, with the ends gradually tapering to a fine point. Cell wall smooth, without teeth, granulations or spines. (Facultative Planktont).

Cells $3-7 \mu$ broad, $30-40 \mu$ between apices.

Horse (sss).

This species should not be confused with Selenastrum acuminatus G. S. West non Lagerheim, a species which I have already discussed in connection with Selenastrum Westii G. M. Smith.

Scenedesmus Bernardi G. M. Smith. Pl. 38, Figs. 5-9. Trans. Wis. Acad. Sci., Arts, \& Lett. 18²: 436, pl. 33, figs. 196-208. 1916.

Colonies of 2-4-8 cells. Interior cells fusiform, lunate or sigmoid, with acute apices; alternately arranged with apices in contact with apices or median portion of adjacent cells. Terminal cells fusiform to lunate, frequently at an angle to the plane of the coenobe, in contact with the interior cells by the apex only. Cell wall smooth, without terminal spines or teeth. (Tychoplanktont ?).

Cells $3-6 \mu$ broad, $8-17 \mu$ long.

Monona (rrr).

Scenedesmus bijuga (Turpin) Lagerheim. Pl. 37, Figs. 18-20. Nuova Notarisia 1893: 158. 1893.

Scenedesmus bijugatus (Turpin) Kützing. G. S. West, Brit. Freshw. Algae 220, fig. 92c. 1904.

Coenobes flat, of 2-4-8 cells in a single (rarely subalternate) series. Cells oblong-elliptic to ovoid, with broadly rounded ends. Cell wall smooth, without teeth or spines. (Tychoplanktont).

Cells 4-7 $\mu$ broad, 7-18 $\mu$ long. 4-celled colonies 7-18 $\mu$ broad, 16-25 $\mu$ long.

Fowler (rrr), Lindy (rr), Little Rice (2) (rr), Mill (rr), Poplar (rrr), Silver (2) (rr), Streitor (rr), Upper Turtle (rrr), Wolf (rr). 
var. alternans (Reinsch) Borge. Pl. 38, Figs. 10-11.

Arkiv. för Botanik 6, No. 1: 57. 1906.

Scenedesmus alternans Reinsch, Abh. Senckenb. Naturf. Ges. 6: 135, pl. 20, fig. $\mathrm{D}^{\mathrm{s}} .1866$.

Colonies flat, generally 8-celled, with a very marked alternate arrangement of the component cells. Cells ovoid to elliptic. (Tychoplanktont).

Cells 4-8 $\mu$ broad, 6-15 $\mu$ long. 8-celled coenobia 12-30 $\mu$ broad, $22-45 \mu$ long.

Blake (rr), Devils (1) (rrr), Muskallonge (rr).

Since cultural studies have shown that the alternate arrangement of cells is a constant character it is proper to consider this a distinct variety. The variety has also been found in lakes where the typical form is absent.

\section{Scenedesmus arcuatus Lemmermann. Pl. 38, Figs. 12-14.}

Forschungsbr. a. d. Biol. Stat. zu Plön 7: 112, pl. 1, figs. 2-4. 1899.

Colonies always curved, of 4-8-16 (generally 8) cells arranged in a double row. Cells ovoid, sometimes angular by mutual compression at the base. Coenobia with small interstices between the cells. Cell wall smooth, without spines or teeth. (Euplanktont).

Cells 3-9 $\mu$ broad, 9-17 $\mu$ long. 8-celled coenobia 15-25 $\mu$ broad, $15-40 \mu$ long.

Beaverdam (rr), Blake (rrr), Camp (rrr), Center (ss), Chain (rr), Cochrane (rr), Cranberry (rr), Hillman (r), Lac Court Oreilles (rr), Lac du Flambeau (rr), Little Bass (2) (rr), Little Crooked (rr), Long (1) (rrr), Long (3) (rr), Lower Turtle (rr), Mendota (sss), Meta (rrr), North Turtle (rr), Owen (rrr), Paddock (rrr), Palmer (rrr), Pardee (rr), Pokegama (2) (rr), Reserve (rr), Round (1) (rrr), Sand (1) (rrr), Sand (4) (rrr), Shell (rrr), Sishebogema (rr), Tied Canoe (rr), Upper Turtle (rr), Wolf (r).

One of the few species of the genus that is exclusively confined to the plankton. The curving of the coenobe and the double series of ovoid cells at once separates it from all other species.

var. Capitatus G. M. Smith. Pl. 38, Figs. 15-16.

Trans. Wis. Acad. Sci., Arts, \& Lett. 19 ${ }^{1}$ : 637, pl. 11, figs. 4-5. 1918.

Cells with nodular thickenings at the poles. (Euplanktont).

Cells 5-11 $\mu$ broad, 11-23 $\mu$ long. 8-celled colonies 22-27 $\mu$ broad, $20-35 \mu$ long.

Center (rr). 
var. Platrdisca G. M. Smith. Pl. 39, Figs. 1-3.

Trans. Wis. Acad. Sci., Arts, \& Lett. 18²: 451, pl. 30, figs. 101-105. 1916.

Colonies always flat, generally 8-celled. Cells oblong-elliptic and arranged in a double series. Coenobia with small interstices between the cells. (Facultative Planktont).

Cells 4.5-7.5 $\mu$ broad, 8-17 $\mu$ long. 8-celled coenobia 11-30 $\mu$ broad, 18-30 $\mu$ long.

Camp (rrr), Eagle (rr), Fowler (rr), George (rr), Horse (rrr), Kegonsa (ss), Paddock (rr), Pine (1) (rr).

An alga that has been considered a normal variation of $S$. bijuga but one which, as stated elsewhere (l. c.), seems more closely related to S. arcuatus.

Scenedesmus acutiformis Schröder. Pl. 39, Figs. 4-6.

Forschungsbr. a. d. Biol. Stat. zu Plön 5: 45, pl. 2, figs. 4a-4b. 1897.

Coenobia flat, of 2-4-8 (generally 4) cells arranged in a linear series. Cells fusiform, with acute apices. Cell wall of interior cells with a single ridge that extends from pole to pole on each side; wall of terminal cell with $2-4$ ridges. Poles of cells without spines or teeth. (Facultative Planktont).

Cells 5-8 $\mu$ broad, 16-22 $\mu$ long. 4-celled colonies 16-22 $\mu$ broad, 20-25 $\mu$ long.

Mendota (rr), Rice (1) (rrr).

Only a single longitudinal ridge can be seen in a front view of the cell but the number of ridges is readily ascertained in an end view of cells. The presence of these ridges without accompanying spines or teeth separates this from other species.

Scenedesmus armatus (Chodat) G. M. Smith. Pl. 39, Figs. 7-10.

Trans. Wis. Acad. Sci., Arts, \& Lett. 18²: 460, pl. 29, figs. 90-93. 1916.

Coenobia of 2-4-8 cells arranged in a linear or subalternating series. Cells ovoid to oblong-ellipsoid; with rounded apices. Terminal cells with a single long spine at each pole. Both sides of cells with a longitudinal ridge that may extend from pole to pole but is generally indistinct in the median portion of the cell. (Facultative Planktont).

Cells 4-7 $\mu$ broad, 7-16 $\mu$ long. 4-celled coenobia (without spines) 7-16 $\mu$ broad, 16-25 $\mu$ long. Spines 5-7 $\mu$ long.

Bear (2) (rr), Bear Trap (rrr), Bone (rr), Browns (rr), Carson (rr), Fishtrap (rrr), Horseshoe (2) (rr), Lac Court Oreilles (rr), Little Butternut (rrr), Little Crooked (rr), Loveless (rr), Lynx (rrr), Mendota (rrr), Pardee (rrr), Pine Tree (rr), St. Croix (rrr), Silver (rr), Upper Turtle (rrr), Wolf (rr). 
var. major var. nov. Pl. 39, fig. 11.

Cells up to $9 \mu$ broad and $25 \mu$ long. Spines $15 \mu$ long. (Facultative Planktont ?).

Palmer (rr).

Scenedesmus brasiliensis Bohlin. Pl. 39, Figs. 12-14. Bih. Kgl. Sv. Vet.-Ak. Handl. 23, Afd. 3, No. 7: 22, pl. 1, figs. 36-37. 1897.

Coenobia flat, of 2-4-8 (generally 4) cells arranged in a single linear series. Cells cylindrical to ovoid-ellipsoid, with a single longitudinal ridge extending from pole to pole on each side of the cell. Poles with 1-4 small teeth. (Facultative Planktont).

Cells 3-6 $\mu$ broad, 11-24 $\mu$ long. 4-celled coenobia 11-24 $\mu$ broad, 12-25 $\mu$ long.

Bear (2) (r), Beaverdam (rrr), Chain (rrr), Clare (rrr), Deer (rrr), Jag (rr), Lac du Flambeau (rrr), Lake of the Woods (rrr), Lindy (rr), Little Doctor (rr), Old Taylors (rr), Pine (2) (rr), Rice (1) (rr), White Sand (rrr).

The species may be distinguished from S. denticulatus by the linear ridges on the sides of the cells.

Scenedesmus hystrix Lagerheim. Pl. 39, Figs. 15-16. öfvers. Kgl. Vet.-Ak. Förh. 39, No. 2: 62, pl. 2, fig. 18. 1882.

Coenobia flat, of 2-4-8 cells joined in a single linear series. Cells oblong-cylindrical, with blunt conical apices. Entire surface of cells covered with minute spines. (Tychoplanktont).

Cells 3-5 $\mu$ broad, 8-18 $\mu$ long. 4-celled coenobia 8-18 $\mu$ broad, 12$25 \mu$ long.

Rudolph (rrr).

Scenedesmus denticulatus Lagerheim. Pl. 39, Figs. 17-19. öfvers. Kgl. Vet.-Ak. Förh. 39, No. 2: 61, pl. 2, figs. 13-17. 1882.

Coenobia flat, generally four-celled. Cells ovoid to ovoid-ellipsoid, arranged in a linear or subalternating series. Poles of cells without ridges but with 1-4 short spines. (Facultative Planktont).

Cells 5-11 $\mu$ broad, 7-15 $\mu$ long. 4-celled coenobia 7-15 $\mu$ broad, 15-22 $\mu$ long.

Amicoy (rr), Bear (2) (rr), Browns (rr), Chain (rr), Deer (rrr), High (r), Hillman (rr), Horse (rrr), Horseshoe (2) (rr), Lac du Flambeau (rrr), Little Doctor (rrr), Silver (3) (rr), White Ash (rr), Wolf (rr). 


\section{Scenedesmus longus Meyen. Pl. 39, Figs. 20-22.}

Nova Acta Phys.-Med. Acad. Caes. Leop. Nat. Cur. 14: 774, pl. 43, fig. 28. 1829. G. M. Smith, Trans. Wis. Acad. Sci., Arts, \& Lett. 18²: 469, pl. 31, figs. 156-158. 1916.

Scenedesmus quadricauda var. setosus (Kirchner) Lagerheim, öfvers. Kgl. Sv. Vet.-Ak. Förh. 39, No. 2: 63. 1882.

Coenobe flat, of 2-4-8 (generally 4) cells arranged in a single linear series. Cells ovoid to oblong-cylindrical, with rounded poles. Poles of all cells with 1-2 spines. Cell wall destitute of spines except at the poles. (Tychoplanktont).

Cells 4-5 $\mu$ broad, 8-11 $\mu$ long. 4-celled coenobia 8-11 $\mu$ broad, 16$20 \mu$ long.

Rock (rr).

var. Naegelii (Brebisson) comb. nov. Pl. 40, Figs. 1-2.

Scenedesmus Naegelii de Brebisson, Mem. de la soc. Imp. de Sc. Nat. de Cherbourg 4: 158.1856.

Scenedesmus caudatus Nägeli non Corda, Gatt. einz. Algen 91, pl. 5, figs. $2 \mathrm{c}-2 \mathrm{~d} . \quad 1849$.

Colonies flat, always eight-celled. Cells cylindrical, with rounded poles. Terminal cells with spines at both poles, interior cells with spines at one pole, rarely at both poles. (Facultative Planktont).

Cells 6.6-11 $\mu$ broad, 18-33 $\mu$ long. 8-celled colonies 18-33 $\mu$ broad, $50-85 \mu$ long.

Blake (rr), Camp (rrr), Poor Farm (rrr), White Ash (rr).

This alga was described by de Brebisson from the drawings of S. quadricauda by Nägeli. In my monograph of Scenedesmus I included it as a synonym of S. longus (Trans. Wis. Acad. Sci., Arts, \& Lett. $18^{2}: 469$. 1916) but am now convinced that it should be considered a distinct variety. The cells are much larger than the typical form but unfortunately Nägeli gives neither measurements for the cells nor an indication of the scale of magnification of his drawings. The measurements stated above are those of cells from Wisconsin lakes. The peculiar arrangement of the spines that Nägeli figures, where three adjacent interior cells have spines on the same end and none on the other with the reverse condition in the remaining interior cells, was found to be a common but not a constant character since specimens were found with spines at both poles of interior cells. 
Scenedesmus abundans (Kirchner) Chodat. Pl. 39, Figs. 23-25.

Matér. p. la fl. crypt. Suisse. $4^{2}: 77$. 1913; G. M. Smith, Trans. Wis. Acad. Sci., Arts, \& Lett. 18²: 465, pl. 31, figs. 137-140. 1916.

Scenedesmus quadricauda var. abundans (Kirchner) Lagerheim, öfvers. Kgl. Vet.-Ak. Förh. 39, No. 2: 64, pl. 2, fig. 20. 1882.

Coenobe flat, generally 4-celled. Cells ovoid to oblong-ellipsoid. Terminal cells with 1-2 spines at poles and additional spines on outer face between the poles. Interior cells with 1-2 spines at each pole. (Facultative Planktont).

Cells 4-7 $\mu$ broad, 7-12 $\mu$ long. 4-celled coenobia 7-12 $\mu$ broad, 15-30 $\mu$ long. Spines 4-7.5 $\mu$ long.

Beaver (2) (rr), Cochrane (rr), Diamond (rr), Grassy (rr), Horse (rr), Long (1) (rrr), Nancy (rrr), Palmer (rr), Poor Farm (ss).

var. longicauda G. M. Smith. Pl. 39, Figs. 26-27.

Trans. Wis. Acad. Sci., Arts, \& Lett. 18²: 467, pl. 30, figs. 121-125. 1916.

Cells smaller, ovoid. Spines much longer in proportion to the size of the cells. (Facultative Planktont).

Cells 3-6 $\mu$ broad, 7-9 $\mu$ long. 4-celled coenobia 7-9 $\mu$ broad, 10-15 $\mu$ long. Spines 6-10 $\mu$ long.

Camp (rr), Chain (rrr), Horse (rr), White Ash (rr).

var. brevicauda G. M. Smith. Pl. 40, Figs. 3-5.

Trans. Wis. Acad. Sci., Arts, \& Lett. 18²: 468, pl. 30, figs. 126-132. 1916.

Cells ovoid, smaller. Spines much shorter and never more than three between the polar spines of terminal cells. (Facultative Planktont).

Cells 2.5-5 $\mu$ broad, 5-8 $\mu$ long. 4-celled coenobia 5-8 $\mu$ broad, 10-13 $\mu$ long. Spines 1.5-3.5 $\mu$ long.

Mendota (rr).

var. ASx maetrica (Schröder) G. M. Smith. Pl. 40, Figs. 6-8.

Trans. Wis. Acad. Sci., Arts, \& Lett. 18²: 468, pl. 27, figs. 45-46. 1916.

Scenedesmus quadricauda var. asymmetrica Schröder, Forschungsbr. a. d. Biol. Stat. zu Plön 5: 45, pl. 2, figs. 5a-5c. 1897.

Coenobia generally 4-celled, with oblong-ellipsoid cells. Poles of terminal cells with a single spine. All cells of coenobe with a single median spine perpendicular to the plane of the coenobe and at one side of cell only. (Facultative Planktont).

Cells $2.5-4.5 \mu$ broad, 12-15 $\mu$ long. 4-celled coenobia 12-15 $\mu$ broad. 13-18 $\mu$ long. Spines 7-10 $\mu$ long.

Blue Gill (rr), Wild Goose (rrr). 
Scenedesmus quadricauda (Turpin) de Brebisson. Pl. 40, Figs. 9-11.

Mém. de la Soc. Ac. de Falaise 1835: 66. 1835; G. S. West, Brit. Freshw. Algae 220, figs. 92D-92F. 1904.

Coenobia flat, of 2-4-8-16 (generally 4) cells in a simple linear or subalternating series. Cells cylindrical-ovoid, with rounded poles. Poles of terminal cells with a single long straight or curved spine. Poles of interior cells without spines. (Facultative Planktont).

Cells 3.5-6 $\mu$ broad, 11-16 $\mu$ long. 4-celled coenobia 11-16 $\mu$ broad, 12-23 $\mu$ long. Spines 10-12 $\mu$ long.

Beaverdam (rr), Big Butternut (rrr), Blake (rr), Browns (rr), Camp (rr), Chetek (rr), Clam (rr), Clear (rr), Eagle (rr), East (rrr), Fishtrap (rr), Green (1) (rr), Hillman (rr), Horseshoe (2) (rr), Lac du Flambeau (rr), Lindy ( $r r)$, Little Rice (2) (r), Lost (rr), Loveless (rr), Lower Nashotah (rr), Lower Nemahbin (rr), Mary (rr), Meta (rr), Mud (1) (rr), Mud (2) (rr), Muskallonge (r), Nancy (rr), Okauchee (rrr), Old Taylors (rr) Pokegama (1) (rr), Pope (rr), Poplar (rr), Poor Farm (sss), Rice (1) (rr), Round (3) (rr), Sand (1) (rrr), Sand (4) (rr), Travis (ccc), White Ash (rr), Wild Goose (rrr), Winnebago (rr).

The most ubiquitous species of the genus. The presence of spines on the poles of the terminal cells only is the distinguishing feature of the species. Cultural work has shown that it is possible to recognize several distinct varieties of this species.

\section{var. Parvus G. M. Smith. Pl. 40, Fig. 17.}

Trans. Wis. Acad. Sci., Arts, \& Lett. 18²: 480, pl. 31, figs. 162-166. 1916.

Cells ovoid-cylindrical. Length of cells 2-2.5 times the breadth and equal to the length of the spines. (Tychoplanktont).

Cells $3-4 \mu$ broad, $5.5-8 \mu$ long. 4-celled coenobia 5.5-8 $\mu$ broad, 12-15 $\mu$ long. Spines 4.5-8 $\mu$ long.

Deer ( $r r r)$.

var. QUadrispina (Chodat) G. M. Smith. Pl. 40, Figs. 15-16.

Trans. Wis. Acad. Sci., Arts, \& Lett. 18²: 479, pl. 31, figs. 167-171. 1916.

Cells broadly ovoid, about twice as long as broad. Spines short, about as long as the diameter of the cell. (Tychoplanktont).

Cells $3.5-8 \mu$ broad, 8.5-15 $\mu$ long. 4-celled coenobia 8.5-15 $\mu$ broad, 16-32 $\mu$ long. Spines 2.5-5.5 $\mu$ long.

Mill (rrr), Pine (rr), Pokegama (1) (rrr), Round (1) (rr), Tied Canoe (rrr). 
var. Longispina (Chodat) G. M. Smith. Pl. 40, Figs. 12-14.

Trans. Wis. Acad. Sci., Arts, \& Lett. 18²: 480, pl. 31, figs. 159-161. 1916.

Cells ovoid-cylindrical. Length of cells 2.5 times the breadth. (Facultative Planktont).

Cells 3.5-5 $\mu$ broad, 8-11 $\mu$ long. 4-celled coenobia 8-11 $\mu$ broad, 12-20 $\mu$ long. Spines 7.5-10 $\mu$ long.

Horse (rr), Lost (rr), Mendota (sss), Palmer (r).

var. WestiI G. M. Smith. Pl. 41, Figs. 3-7.

Trans. Wis. Acad. Sci., Arts, \& Lett. 18²: 480, pl. 32, figs. 177-180. 1916.

Cells 4.5-8 $\mu$ broad, 16-22 $\mu$ long. 4-celled coenobia 16-22 $\mu$ broad, 25-35 $\mu$ long. Spines 12-16 $\mu$ long. (Facultative Planktont).

Bear Trap (rrr), Blake (rr), Camp (rr), Cochrane (rr), Crawling Stone (rr), Grassy (rr), Horse (rrr), Lac Court Oreilles (rr), Loon (rrr), Meta (rr), Silver (2) (rr).

var. maximus W. \& G. S. West. Pl. 41, Figs. 1-2.

Trans. Linn. Soc. 2 Ser. Bot. 5: 83, pl. 5, figs. 9-10. 1895.

Cells much larger and spines proportionally longer. (Facultative Planktont).

Cells 9-11.5 $\mu$ broad, 27-36 $\mu$ long. 4-celled coenobia 27-36 $\mu$ broad, 35-40 $\mu$ long. Spines 20-30 $\mu$ long.

Eagle (rr), Nicaboyne (rr), Pine Tree (rr), Poor Farm (rr), Tenderfoot (rrr), Travis ( $r$ ).

Scenedesmus opoliensis P. Richter. Pl. 41, Figs. 8-11.

Zeits. f. angw. Mikr. 1: 7, figs. A-E. 1896.

Coenobia flat, of 2-4-8 (generally 4 ) cells in a single linear series. Interior cells naviculoid, outer margin of terminal cells straight or slightly convex. Cells in lateral contact in median third only. Terminal cells with a long spine at each pole; interior cells with or without long or short spines. Polar spines greatly reduced at times. (Facultative Planktont).

Cells 5-8 $\mu$ broad, 12-28 $\mu$ long. 4-celled coenobia 12-28 $\mu$ broad, 15-30 $\mu$ long. Spines 5-28 $\mu$ long.

Palmer (rr).

The navicular shape of the cells, their lateral contact in the median third only, together with the beak-like instead of rounded apex separates this species from $S$. quadricauda. 


\section{Sub-family COELASTREAE.}

Coenobia forming a sphere with the cells radially arranged in a single layer around a common center. The number of cells in a coenoba always a multiple of two. Cells spherical, polygonal, or elongate cylindrical.

\section{KEY TO THE GENERA.}

Cells spherical, polygonal, or flattened; length never more than twice the breadth.

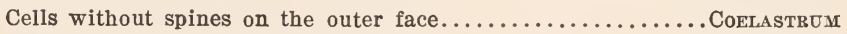

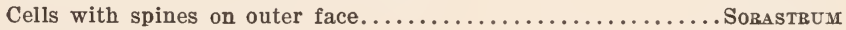

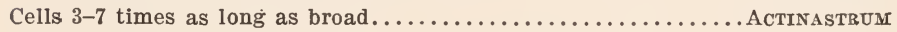

\section{COELASTRUM Nägeli 1849.}

Coenobe a hollow sphere of 2-4-8-16-32-64-128 cells. Cells spherical, ovoid, or pyramidal; compressed or with large intercellular spaces; enclosed in a very delicate gelatinous sheath. Daughter coenobia sometimes remaining joined in multiple coenobia by the remains of the old mother cell wall.

Reproduction by autocolony formation in any cell of the coenobe. Liberation of young coenobia by a rupture of old mother cell wall.

Cells spherical.

\section{KEY TO THE SPECIES.}

Processes uniting the cells long. C. Reticulatum

Processes uniting the cells short.

External face of cells without projections............. Microporum

External face of cells with short truncate projections...C. CAMBricum

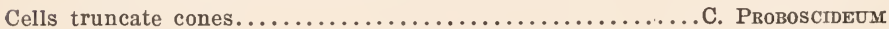

Coelastrum microporum Nägeli. Pl. 41, Figs. 12-13; Pl. 42, Fig. 1. in Braun, Alg. unicell. 70. 1855; Senn, Bot. Ztg. 57: 53, pl. 2, figs. 11-17. 1899.

Coenobia spherical to ovoid; with 8-16-32-64 cells. Cells spherical, enclosed by a delicate gelatinous sheath and connected to one another by short, stout, gelatinous processes. Intercellular interstices smaller than the diameter of the cells. (Facultative Planktont).

Diam. cells (without sheath) 3-20 $\mu$; (with sheath) 4-23 $\mu$. Diam. coenobia 20-90 $\mu$.

Balsam (rrr), Bear (1) (rr), Bear (2) (rr), Bear Trap (rrr), Big Butternut (rrr), Blake (rrr), Bone (rrr), Boulder (rrr), Browns (rr), Center (rr), Chetac (rr), Cochrane (rr), Deer (rrr), East (rrr), Elizabeth (rr), Fishtrap (rrr), Granite (rr), Hill (rr), Hillman (rrr), Horseshoe (2) (rrr), 
Island (rr), Lac du Flambeau (sss), Little Bass (2) (rr), Little Butternut (rr), Little Crooked (rrr), Little Doctor (rr), Loveless (rrr), Lower Nashotah (rrr), Lower Turtle (rr), Mary (rr), Mendota (sss), Mill (rrr), Mud (2) (rr), Nancy (rrr), Oconomowoc (rr), Otter (rrr), Pewaukee (rrr), Pine Treo (rrr), Pokegama (1) (rr), Pokegama (2) (rr), Poor Farm (rrr), Pope (rrr), Prairie (rrr), Round (1) (rrr), Sand (1) (rr), Sand (4) (rr), Shell (rrr), Silver (1) (rr), South Turtle (rr), Squirrel (rr), Tenderfoot (rr), Tied Canoo (rrr), Travis (rrr), Vermilion (rr), White Ash (rrr), White Sand (rrr), Wolf (rrr).

A species that is found in all types of lakes.

\section{Coelastrum cambricum Archer. Pl. 42, Figs. 2-3.}

Quart. Jour. Micr. Sci. N. S. 8: 65. 1868; W. West, Jour. of Bot. 31: 99, pl. 333, fig. 14.1893.

Coenobia spherical, of 8-16-32-64-128 (generally 32) cells. Cells spherical, with a single truncate projection on the outer face. Each cell connected to adjacent ones by short, somewhat flattened, gelatinou projections. Small circular or triangular interstices between the cells. (Facultative Planktont).

Diam. cells (with sheath) 6-21 $\mu$, (without sheath) 5-18 $\mu$. Diam. coenobia $20-100 \mu$.

Balsam (rrr), Bear (2) (rr), Beaverdam (rr), Birch Island (rrr), Blue Gill (rrr), Catfish (rr), Cochrane (rrr), Cranberry (rr), East (rr), Found (rr), Hillman (rrr), Jag (rr), Little Bass (2) (r), Mercer (rr), Middle McKenzie (rrr), Minocqua (rr), Nancy (rrr), Nicaboyne (rr), Old Taylors (rrr), Owen (rrr), Pine (1) (rr), Pine Tree (rr), Pokegama (1) (rr), Prairie (rr), Rudolph (rrr), St. Croix (rr), Silver (1) (rr), Streitor (rr), Travis (r), Wild Goose (rrr).

\section{Coelastrum recticulatum (Dangeard) Senn. Pl. 42, Figs. 4-6.} Bot. Ztg. 57: 66, pl. 2, figs. 1-10. 1899.

Coenobia spherical, of 8-16-32 cells; generally held in multiple coenobia by the remains of old mother cell walls. Cells spherical, enclosed by a narrow gelatinous sheath and connected to adjacent cells by 6-9 long, slender, tough, gelatinous processes. (Facultative Planktont).

Diam. cells (with sheath) 6-24 $\mu$. Diam. coenobia 10-65 $\mu$.

Bear Trap (rrr), Bear (3) (rr), Beaverdam (rrr), Big McKenzie (rrr), Birch (2) (rr), Blake (rrr), Browns (ss), Camp (rr), Fish (rr), High (rrr), Island (rr), Lac Court Oreilles (rr), Little Bass (2) (rr), Mary (rr), Mendota (rr), Mud (1) (rr), Mudhen (rr), Nancy (rr), North Twin (rrr), Palmer (rr).

The long processes connecting the cells distinguish this species from all others. Solitary coenobia are rarely met with since the long processes hinder the escape of young coenobia. 
Coeldastrum proboscideum Bohlin. Pl. 42, Figs. 7-8; Pl. 43, Figs. 1-2. Bih. t. Kgl. Sv. Vet.-Ak. Handl. 23, Afd. 3, No. 7: 33, pl. 2, figs. 19-22. 1897.

Coenobia pyramidal or cubical, rarely polygonal; of 4-8-16-32 (generally 4 or 8) cells ; frequently joined in compound coenobia of irregular shape. Cells truncate cones, at times with concave sides; with base of cone towards the center of coenobe. Interstices between cells large, polygonal. Chloroplast single, parietal, with one pyrenoid. (Facultative Planktont).

Diam. cells $6.5-17 \mu$; diam. 4-celled coenobia 12-35 $\mu$; compound coenobia up to $350 \mu$ in diam.

Bear Trap (rrr), Cochrane (rr), Durchmans (rrr), Pine Tree (aa), Round (rrr).

The appearance of this alga as the dominant organism of the plankton of Pine Tree lake is of particular interest since Coelastrum species have not been reported as occurring in abundance by any student of the phytoplankton. Compound coenobia were very common and it was not at all unusual to find 50-80 four- or eight-celled coenobia joined in one irregular mass. The cells of four-celled coenobia are tetrahedrically arranged in the manner that G. S. West has described them for Coelastrum compositum (Jour. Linn. Soc. Bot. 38: 136, pl. 5, figs. 8-9. 1907) and I believe that $C$. compositum should be considered a synonym of C. proboscideum. The cellular arrangment of eight-celled coenobia is exactly as Bohlin and Senn describe. In the sixteen-celled coenobia, which are of very rare occurrence, the cells form a hollow sphere so that the general appearance of the colony resembles the other species of the genus. This difference in cell number is of minor significance, the number of cells in a colony being dependent upon the vegetative vigor of the mother cell at the time colony formation takes place.

\section{SORASTRUM Kützing. 1845.}

Cells pyriform, semilunar, or reniform; united to form spherical colonies of 8-16-32-64-128 cells. Center of colony a polyhedral body from which gelatinous strands radiate to each cell. Distal side of cells with 1,2 , or 4 spines. Chloroplast diffuse, with one pyrenoid.

Reproduction unknown; presumably by autocolonies as in Coelastrum, possibly by zoospores as in Pediastrum. 
KEY TO THE SPECIES.

Spines on outer face of cells short $(4-8 \mu) \ldots \ldots \ldots \ldots \ldots \ldots$. S. Spindosum Spines on outer face of cells long $(10-15 \mu) \ldots \ldots \ldots \ldots \ldots \ldots$. . A AmEricandum

\section{Sorastrum spinulosum Nägeli. Pl. 44, Figs. 4-5.}

Gatt. einz. Algen 99, pl. 5, figs. Da-Dd. 1849; G. S. West, Brit. Freshw. Algae 215, figs. $89 \mathrm{~A}-89 \mathrm{~B}, 1904$.

Coenobe of 4-8-16-32 cells. Cells broadly reniform to euneate, with four short horns at the corners of the outer face. Stipe leading to sphere at center of colony short. Chloroplast single, generally filling the entire cell; pyrenoid single. (Tychoplanktont).

Cells $8-20 \mu$ broad, $6-18 \mu$ long, $5-8 \mu$ thick. Horns of adult cells 4-8 $\mu$ long.

Hillman (rrr), Horse (rrr).

Sorastrum americanum (Bohlin) Schmidle. Pl. 44, Fig. 1.

Engl. Jahrb. 27: 230. 1900: Lemmermann, Arch. f. Hydrob. u. Planktonkde. 5: 310 , fig. 5.1910.

Selenosphaerium americanum Bohlin, Blh. t. Kgl. Sv. Vet.-Ak. Handl. 23, Afd. 3, No. 7: 40, pl. 2, figs. 38-41. 1897.

Coenobia spherical, solitary, of 16-32-64-128 (generally 16 or 32 ) cells. Cells cardiate to pyramidate, somewhat flattened, with the apex towards the center of the coenobe and ending in a broad gelatinous stalk as long as the cell. Stalk cylindrical, 5-6 faceted at the base; with the facets in contact with those of other stalks and forming a hollow sphere. Outer face of cells emarginate, with a single long spine at each of the four corners. (Facultative Planktont).

Cells 7-20 $\mu$ broad, 5-20 $\mu$ long (without stalk), 4-8 $\mu$ thick. Spines of adult cells 10-15 $\mu$ long.

Devils (1) (rr), Devils (2) (rrr), Nancy (rrr), Travis (rr).

The longer spines and stalk, together with the more prominent central sphere, separates this species from the foregoing.

var. undulatum G. M. Smith. Pl. 44, Figs. 2-3.

Trans. Wis. Acad. Sci., Arts, \& Lett. 19' : 640, pl. 13, fig. 7. 1918.

Sides of facets at base of stipe undulate. Dimensions as in the typical form. (Facultative Planktont).

Beaverdam (rrr). 


\section{ACTINASTRUM Lagerheim 1882.}

Coenobia free-floating, of 4-8-16 (generally 8), ovoid, cylindrical, club-shaped, or drum stick shaped cells radiating from a common center. Coenobia sometimes united to form multiple coenobia of irregular shape. Each cell with a single, laminate, parietal chloroplast; with or without pyrenoids.

Reproduction by longitudinal and transverse division of the contents of any cell, the young autocolony being liberated by a rupture of the mother cell wall.

\section{KEY TO THE SPECIES.}

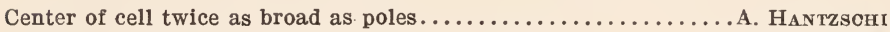
Center of cells about the same width as the poles............. Grachulaum

Actinastrum gracillimum G. M. Smith. Pl. 43, Figs. 3-5. Bull. Torr. Bot. Cl. 43: 480, pl. 26, fig. 23. 1916.

Coenobia of 4 or 8 cells radiating from a common center. Cells elongate-cylindrical, tapering but slightly to a truncate end, 7-10 times as long as broad. Chloroplast single, parietal, laminate, with or without a pyrenoid. (Euplanktont).

Cells 1.75-3 $\mu$ broad, 14-21 $\mu$ long; colonies $30-45 \mu$ in diam.

Horse (rr), Kegonsa (rrr), Mendota (rr).

The species differs from the following in the very slight dilation of the median portion of the cell and the greater proportional length.

\section{Actinastrum Hantzschi Lagerheim. Pl. 43, Figs. 6-7.}

öfvers. Kgl. Vet.-Ak. Förh. 39, No. 2: 70, pl. 3, figs. 25-26. 1882.

Coenobia of 4 or 8 cells radiating from a common center. Coenobia sometimes united to form multiple coenobia. Cells 3-6 times as long as broad, with truncate poles, ovoid-cylindrical. Diameter of middle of cells twice that of poles. Chloroplast single, parietal, laminate; with one pyrenoid. (Euplanktont).

Cells 3-6 $\mu$ broad, 10-26 $\mu$ long; coenobia up to $50 \mu$ in diam; compound coenobia up to $200 \mu$ in diam.

Chetek (rr), Kegonsa (r), Lower Turtle (rrr), Mendota (rr), Prairie (rr), Upper Turtle (rr), Waubesa (rrr).

Multiple coenobia are of rare occurrence and have only been found in the plankton of Chetek lake. This may be due to the fact that such colonies readily fragment into the individual coenobia and the handling incident to the collection of samples is sufficient to break up multiple coenobia. 
var. Elongatum G. M. Smith. Pl. 43, Fig. 8.

Trans. Wis. Acad. Sci., Arts, \& Lett. 19': 636, pl. 12, fig. 3. 1918.

Colonies of 4 or 8 cells. Cells cylindrical, tapering but little towards the poles. (Euplanktont).

Cells 4-5 $\mu$ broad, 30-35 $\mu$ long.

Bear (3) (rr).

The cells of this variety are much longer than those of the typical form.

Family $H Y D R O D I C T Y A C E A E$.

Cells cylindrical, or flattened and hexagonal to trapezoidal with one, two, or four projections. Coenobia of definite shape; cylindrical with a large number of cells; or disciform with 2-4-8-16-32-64-128 cells. Cells incapable of division after their formation. Chloroplast single, parietal, laminate to reticulate, frequently filling the entire mature cell; with one to many pyrenoids.

Asexual reproduction by the division of contents of any cell to form zoospores that swarm within old cell wall or within a gelatinous vesicle extruded from the cell. Zoospores becoming apposed in the shape of the adult cell when they come to rest.

Sexual reproduction by isogamous zoogametes which fuse in pairs to form angular resting cells which form colonies on their germination.

\section{KEY TO THE GENERA.}

Coenobe a hollow cylindrical tube with rounded ends.......... HYDRoDICTYon Coenobe a flattened disc one cell in thickness.

Number of cells in coenobe always $2 \ldots \ldots \ldots \ldots \ldots \ldots \ldots$ EuAstropsis Number of cells in coenobe $4-8-16-32-64-128$, very

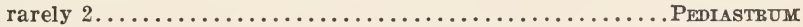

\section{HYDRODICTYON Roth 1800.}

Cells macroseopic, oblong-cylindrical with rounded ends; united to form a free-floating, reticulate, saceate coenobium. Meshes of nets 3-12 (generally 5-6) sided. Cells coenocytic; chloroplast parietal, reticulate at first, later diffuse; pyrenoids single in very young cells, several hundred in mature cells.

Asexual reproduction by the division of cell contents into very many biciliate zoospores which swarm about in and become arranged as in the mature coenobe within the old mother cell wall. Liberation of the young coenobe by a gradual gelatinization of the mother cell wall.

Sexual reproduction by zoogametes which are similar in structure to 
zoospores but smaller, the zoogametes fusing in pairs to form a spherical zygote after their liberation through a pore in the cell wall. Zygote germinating, after a short period of rest, into 2-5 large uni- or biciliate zoospores that form irregular polyhedral cells on coming to rest. Polyeders ultimately germinating into 200-300 zoospores that are liberated in a vesicle and form a net as in asexual reproduction.

Hxdrodictyon Reticulatum (L) Lagerheim. Pl. 44, Fig. 6; Pl. 45, Fig. 1.

öfvers. Kgl. Vet.-Ak. Förh. 40, No. 2: 71. 1883; G. S. West, Brit. Freshw. Algae 208, figs. 84A-84F. 1904

Cells elongate cylindrical, forming a definite closed net. (Tychoplanktont).

Cells 5-250 $\mu$ broad, up to $1.5 \mathrm{~cm}$. long. Coenobia up to $30 \mathrm{~cm}$. long.

Little Bass (2) (rr), Mendota (rr), Monona (sss).

An alga that is in no sense a plankton organism but one which sometimes grows in abundance in shallow, well protected bays and so may, at times, be found free-floating in large patches a considerable distance from the shore.

\section{PEDIASTRUM Meyen 1829.}

Coenobia disciform to stellate, free-floating, of 2-4-8-16-32-64-128 cells arranged in a layer one cell in thickness. Coenobe entire, perforate, or clathrate. Marginal cells polygonal, with one, two, or four processes that sometimes terminate in a tuft of long hyaline setae. Interior cells polygonal, without processes. Cell wall smooth, granulate, or covered with a meshwork of fine ridges; without a gelatinous sheath. Chloroplasts parietal and disciform at first, later filling the entire cell; with 1-4 pyrenoids. Cells coenocytic.

Asexual reproduction by the division of contents of any cell into 2-4-8-16-32-64-128 biciliate zoospores that are extruded in a gelatinous vesicle and, after a short period of swarming, on becoming quiescent appose themselves in the same position as the mature cells of the coenobe.

A fusion of biciliate zoogametes into polyhedral resting cells has been observed. On germination these zygospores form 8-16-32 zoospores that behave as in asexual reproduction. 


\section{KEY TO THE SPECIES.}

Outer face of marginal cells without projections.

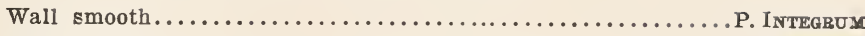

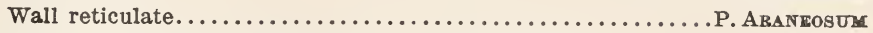

Outer face of marginal cells with 1,2, or 4 projections.

Marginal cells with more than one projection.

Cells on margin with four projections and a deep linear incision..P. TETRAa

Cells on margin with two projections.

Coenobe entire.

Cell wall smooth or punctate.

Projections side by side in front view of cell........... BoRYANUM

Projections above one another in front view.......... K. KAWRAISKYr Cell wall reticulate.

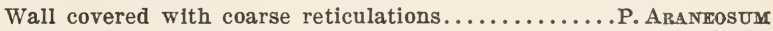

Wall covered with fine reticulations.............. SculptatuM

Coenobe perforate.

Ends of projections truncate...................... Duplex

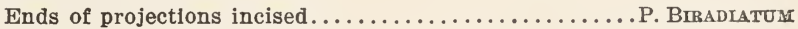

Marginal cells with one projection..................... Srmplex

Pediastrum simplex var. duodenarium (Bailey) Rabenhorst. Pl. 45, Figs. 2-6.

F1. Eur. Algarum 3: 72. 1868.

Monactinus duodenarius Bailey, Smithsonian cont. to knowl. 7, Art. 3: 14, pl. 1, fig. 37. 1855.

Monactinus octonarius Bailey, ibid. p. 14, pl. 1, fig. 36. 1855.

Pediastrum simplex var. clathratum (Schröter) G. S. West, Jour. Linn. Soc. Bot. 38: 134. 1907.

Coenobia circular to oval, of 4-8-16-32-64-128 (generally 8-16-32) cells. Inner face of marginal cells concave, outer face produced into a single, delicately tapering, concave process frequently furnished with a tuft of delicate hyaline setae. Interior cells as those of the periphery but with shorter processes. Interstices between cells large. Cell wall smooth or finely punctate. (Facultative Planktont).

Cells 10-24 $\mu$ broad, 20-45 $\mu$ long.

Balsam (rr), Bear (1) (r), Bear Trap (rrr), Blake (r), Camp (rr), Green (1) (rrr), High ( $r r$ ), Hillman (rrr), Kegonsa (rr), Little Bass (rr), Little Butternut ( $r$ ), Little Crooked (rrr), Lost (rr), Loveless (rrr), Mary (rr), Monona (r), Mud (2) (rr), Palmer (rrr), Pokegama (1) (sss), Rice (1) (r), St. Croix (rr), Silver (1) (rr), Spirit (rr), Upper Turtle (r), Vermilion (cc), Wapagossett (r), White Ash (rr), Winnebago (rr), Wolf (rrr).

This alga is one that has been given a number of names by various investigators, but for the reasons stated elsewhere (Trans. Wis. Acad. Sci., Arts, \& Lett. $19^{1}: 642$. 1918) I consider the one given above the proper name. 


\section{Pediastrum integrum Nägeli. Pl. 45, Fig. 7.}

Gatt. einz. Algen 97, pl. 5, figs. B4a-B4r. 1849.

Coenobia 8-16-32-64-celled, circular or oval, without perforations. Interior cells polygonal ; marginal cells 5-6 sided, at times with rudiments of two projections that are sometimes reduced to a single wart, but generally without projections. Cell wall smooth or punctate. (Tychoplanktont).

Diam. cells $15-30 \mu$.

Soft (rrr).

var. PRIVA Printz. Pl. 45, Figs. 8-10.

Skr. Vidensk. 1 Kristiana Mat.-Naturv. Kl. 1913': No. 6: 73, pl. 5, fig. 147. 1914.

Coenobia generally 8-celled. Marginal cells trapezoidal, without incisions or processes. Interior cells polygonal, without incisions. Cell wall smooth. (Facultative Planktont).

Diam. cells 8-10 $\mu$. Diam. 8-celled coenobia 15-25 $\mu$.

Palmer (rr).

The general shape of the cells is like that of $P$. tetras but since there are no incisions in the cells they cannot be placed among the varieties of $P$. tetras.

\section{Pediastrum araneosum Raciborski. Pl. 45, Fig. 11.}

Mem. Acad. Imp. Sci. Cracow 20: 84. 1890.

Coenobia circular to oval, without perforations, of 8-16-32-64-128 cells. Interior cells in contact with 4-6 other cells, straight sided. Inner half of marginal cells similar to interior cells, outer half without processes but with a deep emargination. Surface of cell covered with a coarse reticulum of ridges. (Facultative Planktont).

Diam. cells 15-32 $\mu$.

Birch Island (rr), Blue Gill (rrr), Boulder (rrr), Carson (rrr), Deer (rrr), Devils (1) (rrr), Diamond (rrr), Dutchmans (rr), Horseshoe (1) (rr), Lake of the Woods (rrr), Lindy (rr), Loon (rrr), Nicaboyne (rr), Nancy (r), Pine Tree (rr), Pokegama (1) (rrr), Poor Farm (rrr), Sand (2) (rr), Wild Goose ( $r$ r).

var. Rugulosum (G. S. West) G. M. Smith. Pl. 45, Figs. 12-13.

Bull. Torr. Bot. Cl. 43: 476, pl. 25, fig. 14. 1916.

Sides of cells undulate where they are in contact with one another. (Facultative Planktont).

Meta (r). 
Pediastrum sculptatum G. M. Smith. Pl. 46, Fig. 1. Bull. Torr. Bot. Cl. 43: 475, pl. 25, fig. 13.1916.

Coenobia oval to circular, of 8-16-32 cells. Interior cells with 4-6 straight sides, with a few interstices between the cells. Marginal cells bilobed, with the lobes produced into two short divergent or parallel processes. Cell wall covered with a network of very fine ridges. (Facultative Planktont).

Diam. cells 10-15 $\mu$. Diam. coenobia 80-150 $\mu$.

South Turtle (rr).

Pediastrum Boryanum (Turpin) Meneghini. Pl. 46, Figs. 2-7.

Linnaea 14: 210. 1840; G. S. West, Brit. Freshw. Algae 211, figs. 85F-85н. 1904.

Coenobia circular to ovoid, of 4-8-16-32-64-128-256 (generally 816-32) cells that are normally compactly arranged in concentric rings. Interior cells 4-6 sided, with straight sides. Inner half of marginal cells similar to interior cells; outer half produced into two short obtuse processes ending in short spines, slightly to deeply emarginate between the processes. Projections on outer face and their spines sometimes greatly reduced. Wall smooth or granulate. (Facultative Planktont).

Diam. cells 7.5-30 $\mu$. Diam. 16-celled coenobia 40-100 $\mu$.

Balsam (rrr), Bear (1) (rrr), Bear (2) (rrr), Bear (3) (ss), Bear Trap (rr), Beasley (rr), Beaver (rr), Beaverdam (ss), Big Butternut (rr), Birch Isiand ( $r r)$, Blake ( $r r)$, Bloom ( $r$ ), Boulder (rrr), Browns ( $r r$ ), Camp ( $r$ ), Carroll (sss), Carson (rrr), Catherine (rr), Center (ss), Chetac (rr), Chetek (rrr), Clear Crooked (rr), Cochrane (rrr), Crawling Stone (rr), Deer (r), Des Moines (rr), Devils (1) (rr), Eagle (sss), East (rrr), Elizabeth (rrr), Fence (rrr), Fishtrap (rr), Found (rr), Fowler (rrr), Geneva (rr), Granite (rr), Grassy (rr), Green (2) (rrr), Grindstone (rr), Half Moon (rrr), Harris (rr), High (rr), Hillman (rr), Hooker (rr), Horse (rrr), Horseshoe (1) (ss), Kawaguesaga (r), Kegonsa (sss), Kitten (rr), Lac la Belle (rr), Lac Court Oreilles ( $r r$ ), Lac du Flambeau (r), Lindy (rr), Little Bass (2) (r), Little Bear (sss), Little Butternut (rrr), Little Crooked (rr), Little Rice (2) (rr), Little Wood (rrr), Long (2) (rr), Long (3) (rrr), Loveless (r), Lower Nashotah (rrr), Lower Nemahbin (rr), Lower Turtle (rr), Marl (rr), Mary (ss), Mendota (ss), Monona (ss), Mud (1) (r), Mud (2) (r), Mudhen (rr), Muskallonge (rr), Nagawicka (rr), Nancy (sss), Nicaboyne (rrr), Oconomowoc (rr), Old Taylors (rr), Owen (r), Paddock (rrr), Pewaukee (rr), Pine (2) (rrr), Pokegama (1) (sss), Pokegama (2) (r), Pokegama (3) (rr), Poor Farm (rr), Poplar (rr), Prairie (rrr), Rainbow (rr), Reserve (rrr), Rice (1) (rr), Round (1) (sss), Round (2) (rr), St. Croix (rr), Sand (1) (rrr), Sand (3) (rrr), Sand (4) (sss), Silver (2) (r), Spirit (rr), Star (rr), Streitor (rr), Taylor (r), Tenderfoot (rrr), Tied Canoe (rrr), Turtle [North and South] (rr), Up- 
per Turtle (r), Vermilion (rr), Waubesa (r), White Ash (sss), Whitefish (rr), White Sand (rr), Wildcat (rrr), Winnebago (r), Wolf (s).

A species that is almost universally present and one which varies greatly in the character of the marginal cells.

var. undulatum Wille. Pl. 46, Fig. 8.

öfvers. Kgl. Vet.-Ak. Förh. 36, No. 5: 28. 1879.

Sides of cells in contact with other cells undulate instead of straight. (Tychoplanktont).

Winnebago (rr).

var. LONGICORNE Raciborski. Pl. 46, Fig. 9.

Akad. Umiej. w. Krakowie 20: 13. 1889; Printz, Skr. Vidensk. i Kristiana Mat.-Naturv. Kl. 1913, No. 6: 74, pl. 5, fig. 149. 1914.

Horns at the ends of processes much longer than typical form, sometimes swollen at apex. Cell wall smooth or granulate.

Diam. cells up to $40 \mu$. Horns $12-30 \mu$ long.

Bone (rrr).

Raciborski recognizes the forms glabrum and granulatum but, judging by the variation in the nature of the wall in the typical form, these forms should not be recognized.

\section{Pediastrum Kawraisky Schmidle. Pl. 46, Figs. 10-13.}

Arb. d. Botan. Gartens zu Tiflis 2: 269. 1897; Nitardy, Beih. z. Bot. Cent. 32²: 164, pl. 5, fig. 5. 1914.

Coenobia of 16-32-64 cells that are compactly arranged. Interior cells 4-6 sided, sides straight. Inner half of marginal cells as interior cells, outer half with two short projections that lie one above the other when the coenobe is seen in surface view. Cell wall smooth. (Euplanktont).

Diam. cells 9-22 $\mu$. Diam. 32-celled coenobia 60-100 $\mu$.

Big Bass (r), Palmer (rr), Tenderfoot (rrr), Winnebago (r).

The cell shape is quite similar to $P$. Boryanum but the peculiar position of the processes on the marginal cells at once distinguishes this species from all others. Some investigators are inclined to the view that $P$. Kawraiskyi is but a passing condition of $P$. Boryanum that is found for one generation only. I have grown $P$. Boryanum in pure cultures for several years and have never seen a single coenobe with the projections of marginal cells lying one above the other, and so feel confident that $P$. Kawraiskyi is not a temporary growth condition of P. Boryanum. 


\section{Pediastrum duplex Meyen. Pl. 46, Figs. 14-16.}

Nova Acta Phys. Med. Ac. Caes. Leop.-Carol. Nat. Cur. 14²: 772, pl. 43, figs. 6-20. 1829.

Coenobia of 8-16-32-64-128 (generally 16-32) cells, with small lensshaped perforations between the cells. Interior cells more or less rectangular, not in contact with one another in the central portion of the side walls. Inner half of marginal cells similar to interior cells, outer half prolonged into two short truncate processes. Cell wall smooth. (Facultative Planktont).

Diam. cells 11-21 $\mu$.

Balsam (rrr), Bear (2) (r), Birch Island (rr), Browns (rr), Catherine (rr), Center (r), Clam (rrr), Cochrane (rr), Crawling Stone (r), Deer (rr), Des Moines (rrr), Diamond (rrr), Eagle (r), Fishtrap (rr), Found (rr), Fowler (rr), Helen (1) (rr), High (rr), Kawaguesaga (rr), Kegonsa (r), Kitten ( $r$ ), Lac la Belle (r), Lindy (rr), Little Bass (2) (rr), Little Bear (r), Littlo Crooked (r), Little Rice (2) (rr), Long (3) (rrr), Lost (rr), Mendota (sss), Mercer (rr), Meronk (rrr), Monona (c), Nagawicka (rr), Nancy (sss), Nicaboyne (rrr), North Twin (rr), Oconomowoc (rr), Okauchee (rr), Pardee (rr), Pokegama (1) (ss), Pokegama (2) (rr), Poor Farm (r), Poplar (rrr), Round (1) (r), Round (2) (rr), Sand (4) (sss), Sishebogema (rr), Soft (r), South Turtle (sss), Taylor (rr), Tenderfoot (r), Tied Canoe (rrr), Upper Nemahbin (rr), Waubesa (ccc), White Sand (rrr), Wildcat (sss), Wild Goose (rrr), Winnebago (ss), Wolf (sss).

In many cases the marginal cells of this species and the varieties clathratum, reticulatum and gracillimum have a tuft of long hyaline setae at the apex of the projections. Their function is to give buoyancy to the coenobe when living under pelagic conditions. Petersen (Bot. Tids. 31: 161-176. 1911) has been able to demonstrate their presence in other species by means of stains.

var. clathratum (A. Braun) Lagerheim. Pl. 47, Figs. 1-3. ö̊vers. Kgl. Vet.-Ak. Förh. 39, No. 2: 56. 1882.

Cells more deeply emarginate and perforations of disc larger. (Facultative Planktont).

Diam. cells 12-22 $\mu$.

Balsam (rr), Bear (3) (rr), Bear Trap (rr), Beaverdam (sss), Big Butternut (rr), Blake (r), Bloom (rr), Camp (ss), Catfish (rr), Catherine (rr), Chetek (s), Cranberry (rr), East (rrr), Fish (s), Horseshoe (1) (rr), Horseshoe (2) (rr), Lac du Flambeau (rrr), Lac la Belle (r), Little Bass (2) (ss), Little Butternut (r), Little Wood (rrr), Long (1) (rrr), Loveless (sss), Lower Turtle (r), Mary (r), Mendota (r), Middle McKenzie (s), Mud (2) (rr), Mud (3) (sss), Nancy (r), Okauchee (rrr), Old Taylors (rrr), Pokegama (1) (r), Rice (1) (ss), Round (2) (rr), Sand (3) (rr), Sand (4) (r), Spirit (sss), Upper Turtle (sss), Wapagossett (rr), White Ash (r). 
var. Reticulatum Lagerheim. Pl. 47, Figs. 4-7.

öfvers. Kgl. Vet.-Ak. Förh. 39, No. 2: 56, pl. 2, fig. 1. 1882.

Perforations of coenobe very large, oval. Interior cells sub-cruciate to H-shaped. Sides of projections of marginal cells parallel, projections generally terminating in a tuft of delicate long hyaline setae. (Euplanktont ?).

Cells $10-20 \mu$ broad, $15-40 \mu$ long.

Big (rr), Camp (s), Center (s), Chetek (s), Crab (rr), Hill (rr), Hooker (rr), Horse (sss), Island (sss), Kawaguesaga (rr), Little Bear (rr), Little Rice (1) (rr), Lost Bass (r), Loveless (r), Nancy (r), Paddock (rr), Palmer (r), Pardee (r), Pine (2) (rrr), Pokegama (1) (r), Pokegama (3) (ss), Prairie (ss), Reserve (rr), Rice (r), St. Croix (sss), Sishebogema (r), South Turtle (rr), Tenderfoot ( $r r$ ), Waubesa ( $r r$ ), Whitefish (rr), Winnebago (rr).

var. Gracillimum W. \& G. S. West. Pl. 47, Figs. 8-11; Pl. 48, Figs. 1-2. Jour. of Bot. 33: 52.1895.

Cells very narrow, never wider than the processes. Body of marginal cells curved outwards, with two long, somewhat converging processes that have parallel or slightly convex sides. Interior cells like those of margin but with somewhat shorter processes. Perforations of coenobe very large. (Euplanktont).

Cells 10-22 $\mu$ broad, 12-32 $\mu$ long. Diam. 16-celled coenobia 65-140 $\mu$.

Clam (rr), Pine Tree (sss), Travis (r).

The perforations of the coenobe and the extension of the processes are the greatest in this variety. The varieties clathratum, reticulatum, and gracillimum are not sharply defined and it is possible, taking the collections as a whole, to arrange a series that grades almost imperceptibly from the typical form to the variety gracillimum. The individuals from any one lake, however, generally vary within fairly narrow limits so I feel that these varieties should be recognized instead of putting them in one collective species without varieties.

\section{var. RотUndatum Lucks. Pl. 46, Fig. 17.}

Jahrb. d. Westpr. Lehrervereins f. Naturk. 2-3: 31. 1907; Nitardy, Beih. z. Bot. Cent. 32²: pl. 9, fig. 11. 1914.

Projections of marginal cells markedly convex and capitate instead of parallel. (Tychoplanktont).

Oconomowoc (rrr), Horseshoe (1) (rr). 
var. cohaerens Bohlin. Pl. 48, Figs. 3-4.

Bih. t. Kgl. Sv. Vet.-Ak. Handl. 23, Afd. 3, No. 7: 31, pl. 2, fig. 1. 1897.

Pediastrum duplex var. reticulatum forma cohaerens (Bohlin) Brunnthaler, in Pascher, D. Süsswasserfl. Deutschl., österr. u. d. Schw. 5²: 95, fig. 57e. 1915.

Coenobia circular to oval, of 16-32-64 cells, with median-sized intercellular spaces. Wall of cells covered with short, linear, concentrically arranged granules. (Facultative Planktont).

Cells 12-22 $\mu$ broad; 13-24 $\mu$ long.

Pine Tree (r).

\section{Pediastrum biradiatum Meyen. Pl. 48, Figs. 5-8.}

Nova Acta Phys.-Med. Ac. Caes.-Leop. Nat. Cur. 14²: 773, pl. 43, figs. 21-22. 1829.

Pediastrum rotula (Ehrenberg) A. Braun emend. Alg. unicell. 101, pl. 6, tgs. 2-3, 5-7, 10, 12-14. 1855.

Coenobia of 4-8-16-32-64 cells, with medium sized openings between cells. Marginal cells in contact with one another at base only, with two long projections that are dilate and incised at the apex. Interior cells as those of the margin but apices of projections neither dilate nor incised, in contact with other cells at base and ends of projections only. Cell wall smooth. (Facultative Planktont).

Cells 10-22 $\mu$ broad, 15-30 $\mu$ long. Diam. 32-celled coenobia 80-150 $\mu$.

Balsam (rrr), Bear (3) (rr), Big McKenzie (rr), Lac du Flambeau (rr), Mud (2) (rr), Nancy (rrr), Pokegama (1) (rrr), Wolf (rrr).

This species resembles $P$. duplex var. reticulatum in the perforation of the disc but differs in the deep incision of the marginal cell projections. Perfect colonies are seldom seen since apices of projections of certain interior cells are free and have the same dilation and incision that is found in the marginal cells. The number of cells in the colony is generally stated as 8-16-32 but the coenobia in the plankton of Wisconsin lakes are 32 - or 64-celled except in very rare cases.

Pediastrum tetras (Ehrenberg) Ralfs. Pl. 48, Figs. 9-12.

Ann. \& Mag. of Nat. Hist. 14: 469, pl. 12, fig. 4. 1844.

Coenobia rectangular, oval or circular; without perforations; of 4-8-16-32 (generally 4-8) cells. Outer face of marginal cells with a single deep linear to cuneate incision, the halves of the outer face slightly to deeply emarginate. Interior cells with a single deep linear incision and 4-6 straight sides. Cell wall smooth. (Tychoplanktont).

Diam. cells 8-15 $\mu$.

Blake (rrr), Browns (rrr), Chain (rrr), Chetek (rr), Cochrane (rrr), Hillman (rrr), Horse (rrr), Horseshoe (2) (rrr), Kimball (rrr), Lindy (rrr), 
Little Doctor (rr), Mendota (rrr), Palmer (rrr), Pewaukee (rrr), Pine (2) (rr), Pokegama (1) (rr), Poor Farm (rr), Tied Canoe (rrr).

The four projections in the outer face of marginal cells are due to a deep emargination of the two halves. This, coupled with the deep incision of all cells, at once separates the species from others of the genus. The alga does not thrive under plankton conditions although it is common in ditches and ponds of the state.

var. OBTUSATA Raciborski.

Akad. Umiej. w. Krakowie 20: 32. 1889; Printz, Skr. Vidensk. i Kristiana Mat.-Naturv. Kl. 1913', No. 6: 78, pl. 6, fig. 153.1914.

Cells larger than typical form, sometimes expanded at base. Halves of outer face of marginal cells entire or very slightly emarginate. (Tychoplanktont).

Diam. cells 14-18 $\mu$; length 18-22 $\mu$.

Beaverdam (rrr).

var. tetraodon (Corda) Hansgirg. Pl. 48, Figs. 13-14; Pl. 49, Figs. 1-2. Prodr. d. Algenfi. v. Böhmen 1: 112. 1888.

Euastrum tetraödon Corda, Almanach de Carlsbad 9: 238, pl. 2, fig. 9. 1839.

Coenobia generally 8-celled. Incision of cells deep, and with projections adjacent to incision very pronounced on marginal cells. (Facultative Planktont).

Diam. marginal cells 8-15 $\mu$; length 12-18 $\mu$.

Pine Tree (rr), Travis (r).

There is no question that my figures of the organism are identical with the one that Nitardy (Beih. Bot. Cent. $32^{2}: 123, p l .5$, fig. 8. 1914) has reproduced from Corda. The variety is sharply defined through the greater development of the projections.

\section{EUASTROPSIS Lagerheim 1894.}

Coenobia free-floating, 2-celled. Cells flattened, approximated at the bases, distal end free and deeply emarginate. Chloroplast single, parietal, with one pyrenoid.

Asexual reproduction by division of cell contents into 2-4-8-16-32 zoospores which are extruded in a vesicle and on becoming quiescent join in pairs to form the characteristic coenobe.

Sexual reproduction unknown. 
Euastropsis Richteri (Schmidle) Lagerheim. Pl. 49, Fig. 3. Tromsö Museums Aarshefter 17: 20, pl. 1, figs. 8-27. 1894.

Cells trapezoidal, outer face deeply emarginate. (Tychoplanktont).

Cells 4.5-25 $\mu$ broad, 5-20 $\mu$ long. Coenobia 4.5-25 $\mu$ broad, 10-40 $\mu$ long.

Kegonsa (rrr).

It is quite possible to mistake 2-celled Pediastrum colonies for E. Richteri, but since such Pediastrum colonies are of very rare occurrence the similarity of the two is not apt to lead to confusion.

\section{Family PLANOSPORACEAE.}

Cells solitary or gregarious; ovoid, pyriform, fusiform, cylindrical, or hemispherical; epiphytic, endophytic, or epizootic. Cells capable of growth but incapable of division after their formation. Generally with a single chloroplast with one or more pyrenoids.

Asexual reproduction by division of eell contents to form many zoospores.

Only one genus, Characium, is found in the plankton of the state.

\section{CHARACIUM A. Braun 1849.}

Cells sub-spherical, ovoid, pyriform, fusiform, or cylindrical; solitary or gregarious; epiphytic or epizootic; generally attached to substratum by a more or less elongate stipe, rarely sub-sessile. Chloroplast parietal and laminate to cup-shaped in young cells; later expanded to fill entire cell: with one or more pyrenoids. Cells at times with several ehloroplasts.

Asexual reproduction by repeated division of cell contents into 8-1632-64-128 zoospores that are liberated through a lateral or apical pore. Zoospores swarming but a short time and then coming to rest on substratum and developing into vegetative cells.

Microgametes reported but doubtful.

\section{KEY TO THE SPECIES.}

Epiphytic upon other algae.

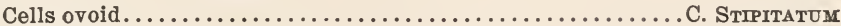

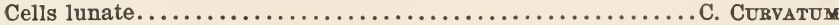
Epizootic upon crustaceans.

Apices of cells rounded....................... Crumpricum

Apices of cells produced into a fine seta.

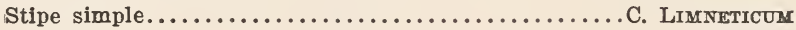

Stipe ending in fliform rhizoids................. Gracturm 
Characium stipitatum (Bachmann) Wille. Pl. 49, Figs. 4-7. In Engler \& Prantl, Nat. Pflanzenfam. $1^{3}$ (Nachtr.); 45. 1909; G. M. Smith, Bull. Torr. Bot. Cl. 43: 472, pl. 24, figs. 4-6. 1916.

Cells spherical to pyriform, with a delicate hyaline stipe somewhat longer than the cell. Chloroplast single, parietal, cup-shaped, always on the side away from the stipe; pyrenoid single. Zoospores broadly ovoid, biciliate, with a cup-shaped chloroplast at the posterior end. (Euplanktont).

Epiphytic upon and embedded within the gelatinous envelope of Coelosphaerium Naegelianum Unger.

Cells 5-8 $\mu$ broad. Stipe 10-16 $\mu$ long.

Amicoy (r), Balsam (rr), Beartrap (rr), Beaverdam (s), Big (rr), Big McKenzie (ss), Clam (ss), Devils (2) (ss), Horseshoe (1) (ss), Horseshoe (2) (rr), Long (2) (ss), Kawaguesaga (ss), North Twin (sss), Pardee (r), Pike (rr), Pokegama (1) (s), Pokegama (2) (r), Poplar (rrr), St. Croix (r), Sand (4) (rr), Sishebogema (rr).

In one case the alga was found upon Oocystis but in all others it was inside the gelatinous envelope of Coelosphaerium Naegelianum Unger. When the alga grows upon Coelosphaerium the colony is apt to be infested with 50-100 individuals as a rule. The alga was originally described as a Chlamydomonas species but since the sessile phase is the dominant one of the life cycle it is better placed as a Characium species. Although found at only one station in Europe it is widely distributed in northern Wisconsin.

\section{Characium curvatum G. M. Smith. Pl. 49, Figs. 8-15.}

Trans. Wis. Acad. Sci., Arts, \& Lett. 19 ${ }^{1}$ : 641, pl. 11, figs. 6-13. 1918.

Cells lunate or recurved, with acute or sub-acute apices. Stipe hyaline, thick, tubular or conical, sometimes irregular in outline. Chloroplast single, parietal, laminate to cup-shaped; with or without a pyrenoid. (Euplanktont).

Epiphytic upon Coelosphaerium Naegelianum Unger, Dictyosphaerium pulchellum Wood, and Phaeococcus planctonicus W. \& G. S. West.

Cells 3-6 $\mu$ broad, 8-18 $\mu$ long (without stipe), 13-22 $\mu$ long with stipe.

Bear (1) (rr), Birch (2) (cc), Chain (rr), Chetac (aa), Chetek (rr), Clam (sss), East (rr), Horseshoe (1) (ss), Lindy (rr), Mud (1) (rr), South Crab (ss), Wild Goose (rr).

An alga that resembles $C$. stipitatum in the manner of growth but one which is found upon a wider range of genera. It also differs in the curved cells and the broader stipe. 
Characium cylindricum Lambert. Pl. 49, Figs. 16-19.

Rhodora 11: 70, pl. 79, figs. 1-2, 7-8, 10-13, 23-25. 1909.

Cells cylindrical, with rounded apices, base tapering slightly into a short stipe without a basal dise. Chloroplasts 1-16, parietal, disciform to laminate, without pyrenoids. (Euplanktont).

On Diaphanosoma brachyura and Branchipus vernalis.

Cells $8-20 \mu$ broad, $20-430 \mu$ long.

Howey (cc).

The lack of a pyrenoid suggests Characiopsis but the bright green color of the chloroplast shows that the alga is one of the Chlorophyceas and so is placed among Characium species. Young cells contain a single chloroplast but with growth there is an increase in the number of chloroplasts and all stages between cells with a single chloroplast and those with sixteen may be found on the same crustacean. Lambert holds that this condition is a stage in the division into zoospores but in my opinion it is the normal condition of the adult cell. Another point of interest is the position of the alga upon the host since it is only found on the tail of the crustacean.

Characium limneticum Lemmermann. Pl. 49, Figs. 25-29.

Bot. Not. 1903: 81, pl. 3, figs. 7-10. 1903.

Cells broadly fusiform, lunate, rarely straight; apex produced into a single delicate hyaline seta; base a delicate stipe without basal dises. 1-8 parietal band-shaped chloroplasts, each containing 1-2 pyrenoids. (Euplanktont).

Cells 5-14 $\mu$ broad, 25-110 $\mu$ long; stipe 5-10 $\mu$ long.

On Diaphanosoma brachyura.

Boulder (rr), Browns (rr), Delavan (rrr).

Lemmermann describes the chloroplast as single but reports a division of the chloroplast prior to division. I have found that in all normal adult cells of $C$. limneticum, $C$. gracilipes, and $C$. cylindricum there is more than one chloroplast.

The species is very closely related to $C$. gracilipes but is much smaller, proportionally broader, and has a simple stipe. It is very probable that Raphidium longissimum var. septatum Chodat (Ankistrodesmus longissimum var. septatum (Chodat) Brunnthaler) is a cell of C. limneticum broken off from the crustacean during collection. 
Characium gracilipes Lambert. Pl. 49, Figs. 20-24.

Rhodora 11: 65, pl. 79, figs. 3-6, 9, 14-22. 1909.

Cells straight or curved with the median portion fusiform; apex tapering into a long seta and base attenuated to a filiform stipe. Chloroplast parietal, band-shaped, 1-32 per cell; with one pyrenoid in each chloroplast. (Euplanktont).

On Diaphanosoma brachyura.

Cells 5-14 $\mu$ broad, 70-480 $\mu$ long.

Howey (cc).

This alga was found on the same organism and at the same time as C. cylindricum. It was confined to the forward appendages while C. cylindricum was found at the tail only.

\section{Order ULOTRICHALES.}

Cells usually in a simple or branched thallus, rarely forming disciform thalli one cell in thickness. Thallus generally attached, rarely free-floating; naked, or enclosed by a tough and leathery or copious and gelatinous, homogeneous or lamellated envelope. Cells generally with a single parietal laminate to cup-shaped chloroplast with one or more pyrenoids. Cell shape usually cylindrical with flattened ends, rarely cylindrical with rounded ends, spherical or cubical.

Asexual reproduction by vegetative cell division, by a division of vegetative or special cells to form 2-16 bi- or tetraciliate zoospores, and by aplanospores.

Sexual reproduction either isogamous by a division of cell contents to form bi- or tetraciliate zoogametes; or heterogamous by the fusion of tetraciliate zoogametes of different size or the union of large non-motile oospheres and small biciliate antherozoids.

\section{KEY TO THE FAMILIES.}

Cells united to form simple filaments................ Ulotrichaceas Cells united to form branching filaments.

Sexual reproduction by isogamous zoogametes......... С HAETOPHorace.aE

Sexual reproduction by heterogamous zoogametes...... APHANochaETACEAE

\section{Family ULOTRICHACEAE.}

Cells united to form simple free-floating or sessile filaments which are enclosed at times by a copious, hyaline, homogeneous or radially fibrillar, gelatinous envelope. Cell shape spherical to cylindrical with rounded or flattened ends. Walls of cells delicate or thick, homogen- 
eous or lamellated. Cells containing a nucleus and one parietal, laminate or cup-shaped chloroplast with one or more pyrenoids.

Asexual reproduction by vegetative cell division, aplanospores or biciliate zoospores.

Sexual reproduction isogamous, by a fusion of bi- or tetraciliate zoogametes.

\section{ULOTHRIX Kützing 1833.}

Filaments simple, free-floating or with the basal cell modified to form a hold-fast. Cells cylindrical, with flattened end walls, united to form simple filaments that are the same diameter throughout. Wall of cells delicate or thick, homogeneous or lamellated, without a gelatinous outer layer. Chloroplast single, parietal, laminate, with one or more pyrenoids. Cells uninucleate.

Asexual reproduction by the division of cell contents to form 1-32 aplanospores and bi- or tetraciliate zoospores.

Sexual ieproduction isogamous, by a fusion of biciliate zoogametes.

KEY TO THE SPECIES.

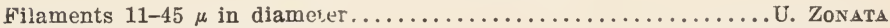

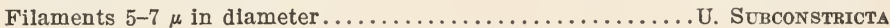

Ulothrix zonata (Weber \& Mohr) Kützing. Pl. 50, Fig. 6. Fiora 16: 519. 1833; Hazen, Mem. Torr. Bot. Cl. 11: 147, pl. 20, figs. 1-4. 1902.

Filaments attached or free-floating and forming greenish masses. Cells disciform to cylindrical, $1 / 3$ to 11,6 times as long as broad. End walls of cells straight, side walls straigit or slightly convex in older cells. Chloroplast forming a broad or narrow paricial annular girdle containing several pyrenoids. Wall of cell thick, generally homogeneous but at times lamellated in structure. (Tychoplanktont).

Mature cells $11-45 \mu$ in diameter.

Mendota (rrr).

Ulothrix subconstricta G. S. West. Pl. 50, Figs. 4-5. Jour. of Bot. 53: 82, figs. 6A-6c. 1915.

Filaments free-floating, narrow, slightly constricted at cross walls of cells, with or without a homogeneous gelatinous envelope. Cells elongate, 2-6 times as long as broad, slightly inflated at the poles. Chloroplast single, parietal, laminate, with irregular edges and occupying the median two thirds of the cell. With or without 1-2 pyrenoids. Cell wall very delicate. (Facultative Planktont). 
Cells 5.7-9 $\mu$ broad.

The specimens that I have found in our lakes differ somewhat from those described by West since the cells are not slightly dilate at the poles and the chloroplasts usually contain pyrenoids. The Wisconsin organism does not seem sufficiently differentiated, however, to warrant the description of a new variety or species. This alga is of particular interest since it is the only one of the order which has become established as a true member of the plankton.

\section{Family CHAETOPHORACEAE.}

Cells united to form branching filamentous, discoidal or parenchymatous thalli. Branches of thallus generally attenuated at apices and sometimes ending in long hair-like processes. Thallus' naked or enclosed in a copious, hyaline, homogeneous, gelatinous envelope. Cell shape ordinarily cylindrical with flattened ends. Chloroplast single, parietal and laminate to girdle-shaped; with one or more pyrenoids. Nucleus single.

Asexual reproduction by aplanospores and bi- or tetraciliate zoospores.

Sexual reproduction isogamous, by a fusion of biciliate zoogametes.

\section{STIGEOCLONIUM Kützing 1843.}

Thallus free-floating or attached, with branches scattered and not arising in dense tufts. Thallus without an appreciable difference in size between the main stem and minor branches; covered with a homogeneous, hyaline, gelatinous envelope. Cells cylindrical to disciform, gradually decreasing in diameter towards the apex and with terminal cells conical or elongated to hair-like unseptate proeesses. Chloroplast single, parietal; gridle-shaped and filling median portion of older cells; completely filling younger cells. Each chloroplast generally containing several pyrenoids.

Asexual reproduction by aplanospores and tetraciliate zoospores.

Sexual reproduction isogamous, by the fusion of biciliate zoogametes.

Stigeoclonium Lubricum (Dillwyn) Kützing. Pl. 50, Fig. 7. Phycol. germ. 189.1845.

Myxonema lubricum (Dillw.) Fries. Hazen, Mem. Torr. Bot. Cl. 11: 195, p?. 28, figs. 1-2. 1902.

Filaments forming dark green tufts up to $30 \mathrm{~cm}$. long. Filaments much branched and branches usually opposite, rarely single. Cells of main filament at base of branches sub-spherical, shorter than other cells. 
Branchlets abundant, opposite, scattered in basal portion, dense in distal, ot:-y shghtly narrower than the branch from which they arise and with terminal cell conical or setiferous. Lower cells of main branch swollen $2 \div-4$ times as long as broad, with a girdle-like chloroplast in inedian portion. (Tychoplanktont).

Main branches 14-16.5 $\mu$ broad; branchlets 6-7 $\mu$ broad.

Mendota (rrr), Wild Goose (rrr).

\section{Family APHANOCHAETACEAE.}

Thallus epiphytic, generally upon other algae, creeping in habit and composed of simple or irregularly branching filaments that taper from the center to short, narrow terminal cells that do not end in terminal setce. Central cells of filament spherical to spherical-cylindrical; those towards the end cylindrical with straight or convex sides; terminal cells conical. Celis generally bearing one or more long, hyaline, unseptate setae with swollen bases. Chloropast parietal, completely filling the cell, or gridle-like and in the median portion; generally with more than one pyrenoid.

Asexual reproduction by tetracliate zoospores or aplanospores.

Sexual reproduction heterogamous, by the fusion of tetraciliate zoogametes that are markedly different in size.

The family contains the single genus Aphanochaete whose characters are those of the family.

Aphanochaete vermiculoides Wolle. Pl. 50, Fig. 8.

Freshw. algae of U. S. 119, pl. 105, figs. 9-10. 1887.

Herposteiron hyalothecae Hansgirg. G. M. Smith, Trans. Wis. Acad. Sct., Arts, \& Lett. 18²: 560. 1916.

Filaments but slightly branched and confined to the peripheral portion and twisted around or arched from the gelatinous envelope of if yalotheca filaments. Cells cylindrical, with straight or convex sides and containing a single chloroplast with $1-4$ pyrenoids. Setae very sparse, rarely more than five on any filament. (Tychoplanktont).

Cells 4-6 $\mu$ broad ; 5-12 $\mu$ long.

Beaverdam (rr).

All other species of the genus grow directly upon the cells of the substratum but the wide gelatinous envelope of the Hyalotheca is in this case sufficiently firm to support the Aphanochaete. The alga has the apnearance of an arching worm crawling along the filament. 


\section{Order SIPHONOCLADIALES.}

Cells multinucleate, generally cylindrical and united to form simple or branched thalli that are, at times, quite complicated in structure. Chloroplasts disciform, parietal and numerous, or united by strands to form a single reticulate structure. Pyrenoids generally present.

Asexual reproduction by zoospores and aplanospores.

Sexual reproduction isogamous by means of zoogametes; or heterogamous by large non-motile oospheres and small motile antherozoids.

The order is largely marine and only one representative, Cladophora, has been found in the plankton.

\section{Family CLADOPHORACEAE.}

Filaments generally sessile, simple or branched, with septations between the cells complete. Walls of cells generally heavy, homogeneous or lamellose, without a gelatinous envelope. Cells with numerous parietal disciform chloroplasts or a single reticulate chloroplast; multinucleate; with a single large central vacuole.

Asexual reproduction by zoospores and akinetes.

Sexual reproduction isogamous, by means of zoogametes.

\section{CLADOPHORA Kützing 1843.}

Filaments branched, with the component cells in a single linear series; lateral branches arising at distal part of main branch cells and generaily with an abundantly developed system of branching. Growth of filaments confined to the apical region. Cells cylindrical, several times as long as broad; multinucleate; with numerous parietal disciform chloroplasts or the chloroplasts united by processes to form a single reticulate chloroplast; pyrenoids numerous.

Asexual reproduction by the formation of many biciliate zoospores in any cell of the filament.

Sexual reproduction isogamous, by means of biciliate zoogametes.

\section{Cladophora glomerata (L.) Kützing. Pl. 50, Figs. 1-3.}

Phycol. gener. 266. 1843; Collins, Tufts Coll. Studies 2: 350, pt. 13, fig. 124. 1909.

Branching of filaments fairly dense in lower portion and very dense at the apex. Ultimate branchlets containing several cells, straight or slightly incurved, with ends rounded but not markedly attenuated. Cells of main branches 6-7 times as long as broad, 3-6 times as broad 
as branchlets. Zoospore formation confined to terminal and subterminal cells. (Tychoplanktont).

Diam. main cells $75-100 \mu$, branchlets $35-50 \mu$.

Mendota (rr).

\section{Division AKONTAE.}

Cells solitary or in filaments, variously shaped, with one or more grass-green chloroplasts that usually contain more than one pyrenoid.

Asexual reproduction ordinarily by vegetative cell division, rarely by aplanospores, never by zoospores.

Sexual reproduction isogamous, always by aplanogametes, never by ciliate zoogametes.

The lack of cilia in every type of reproduction is the great characteristic of the division. It includes but one order, the Conjugales, which forms a very homogeneous though diverse group.

\section{Order CONJUGALES.}

Cells solitary or in simple filaments; cell shape various, eylindrical without median constrictions or bilaterally symmetrical and usually with a median constriction dividing the cell into two symmetrical halves. Cell wall smooth or variously ornamented, with an inner firm portion and an outer gelatinous portion that is very copious at times. Chloroplasts 1-8, variously shaped, axial or parietal, with one to several pyrenoids. Nucleus single, at the center of the cell.

Asexual reproduction by vegetative cell division or aplanospores.

Sexual reproduction isogamous, by aplanogametes.

\section{KEY TO THE FAMILIES.}

Cells cylindrical, without a median constriction, united to

form simple filaments.......................... Z Y

Colls solitary or in filaments, divided into two symmetri-

cal halves, generally with a median constriction.......... DESMIDLACEAE

(See Part II)

\section{Family ZYGNEMACEAE.}

Cells always cylindrical, with ends flattened or replicate, serially arranged to form simple filaments that occasionally have simple lateral matgrowths. Filaments generally free-floating though at times attached by a modification of terminal cell into a basal cell with short rhizoidal processes. Wall of cell firm, homogeneous, with a narrow or copious, homogeneous or radially fibrillar, gelatinous covering. Cell contents eonsisting of a single nucleus, and one to several chloroplasts that are 
either stellate or laminate and axial or parietal. Chloroplasts with one to many pyrenoids.

Asexual reproduction by vegetative cell division or metamorphosis of cell contents into a single large aplanospore.

Sexual reproduction isogamous, by metamorphosis of all or a part of the cell contents into an aplanogamete which fuses with an aplanogamete from the same or another filament. Zygote with 2-3 layers, sometimes germinating immediately but usually after a period of rest.

KEY TO THE GENERA.

Chloroplast stellate.

ZYGNEMA

Chloroplast a longitudinal band.

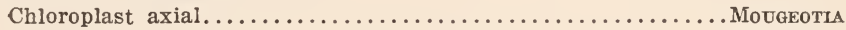

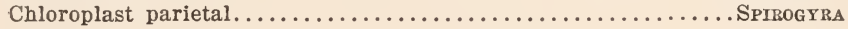

\section{MOUGEOTIA C. A. Agardh 1824.}

Cells cylindrical, generally several times as long as broad. Chloroplast single, forming an axial plate extending the whole length of the cell and generally with several pyrenoids.

Conjugation generally scalariform and with the zygote formed in the conjugation tube. Zygote at times occupying the median portion of male and female gametangia as well as conjugation tube. Wall of zygote of two layers the inner smooth, the outer smooth or sculptured, hyaline or colored.

\section{Mougeotia viridis (Kützing) Wittrock. Pl. 51, Fig. 1.}

Bih. Kgl. Sv. Vet.-Ak. Handl. 1, No. 1: 39. 1872.

Staurospermum viride Kützing. Cooke, Brit. Freshw. Algae 107, pl. 44, figs. 2a-2c. 1882 .

Cells 4-10 times as long as broad. Zygospores normally bounded by four cells, quadrangular, with concave sides and truncate corners. (Tychoplanktont).

Cells $6-8 \mu$ broad. Zygotes $22-32 \mu$ broad.

Okauchee (rrr).

\section{ZYGNEMA C. A. Agardh 1817.}

Cells cylindrical, rarely more than twice as broad as long. Filaments with a terminal cell at times modified to form a holdfast. Cells with one nucleus and two axial stellate chloroplasts each of which contain a single pyrenoid. Conjugation lateral or scalariform, with a formation of zygospores in the conjugation tube or the gametangia. Zygotes spherical to ellipsoid, wall with three layers. 
Zygnema Pectinatum (Vaucher) C. A. Agardh. Pl. 51, Fig. 2. Synop. algarum Scand. 102. 1817; DeBary, Unters. u. d. Fam. d. Conjugaten. 77, pl. 1, figs. 15-19. 1858.

Vegetative cells 1-3 times as broad as long. Zygospore formed in eonjugation tube, with rounded ends. Middle layer of zygote wall brown and scrobiculate. (Tychoplanktont).

Vegetative cells $30-40 \mu$ broad. Zygote $35-40 \mu$ broad.

Oconomowoc (rrr).

\section{SPIROGYRA Link 1820.}

Cells cylindrical, with end walls a flat plane or replicate; united to form simple filaments that may be attached by a modification of the terminal cell into holdfasts. Length of cells slightly greater than to several times the breadth. Chloroplasts one to several, parietal, in long ribbons that extend from end to end in the cell and generally make several spiral turns. Nucleus single, moored in the center of the central vacuole by cytoplasmic strands running to the pyrenoids. Chloroplasts with several pyrenoids that are generally in a single median row.

Conjugation scalariform or lateral, with zygote formation in gametangia and never in the tube. Zygote spherical, ellipsoid, or cylindrieal with rounded ends. Middle layer of zygote hyaline or colored, smroth or sculptured.

Spirogyra Porticalis (Müller) Cleve. Pl. 51, Fig. 3.

Nova Acta Reg. Soc. Sci. Upsaliensis 3, Ser., 6: No. 11, 22, pl. 5, figs. 8-13. $1 \& 68$.

Length of vegetative cells 2-6 times the breadth. Cells with plane cross walls and containing a single chloroplast that makes $3-5$ turns and contains numerous conspicuous pyrenoids. Gametangia but little swollen when zygospore is mature. Zygospores broadly ovoid to sub-cylincirical, with a yellow membrane when mature. (Tychoplanktont).

Diam. cells 30-50 $\mu$. Diam. zygospores $40-50 \mu$.

Mendota (rrr). 
PLATE 1.

Fig. 1. Chroococcus minutus $(\mathrm{x} 825) \ldots \ldots \ldots \ldots \ldots \ldots \ldots \ldots \ldots . \ldots \ldots$

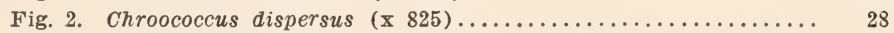

Fig. 3. Chroococcus dispersus var. minor $(\mathrm{x} 825) \ldots \ldots \ldots \ldots \ldots \ldots . \ldots 2$.

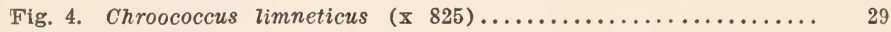

Fig. 5. Chroococcus limneticus var. subsalsus $(x \mathrm{825}) \ldots \ldots \ldots \ldots \ldots . \ldots 23$

Fig. 6. Chroococcus limneticus var. carneus $(x)$ 825) .......... 30

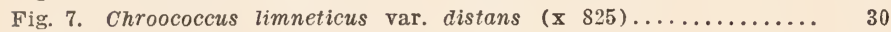

Fig. 8. Chroococcus limneticus var. elegans $(x \quad 825) \ldots \ldots \ldots \ldots \ldots . \quad 30$

Fig. 9. Chroococcus turgidus $(\mathrm{x} 1000) \ldots \ldots \ldots \ldots \ldots \ldots \ldots \ldots \ldots \ldots \ldots \ldots$ 

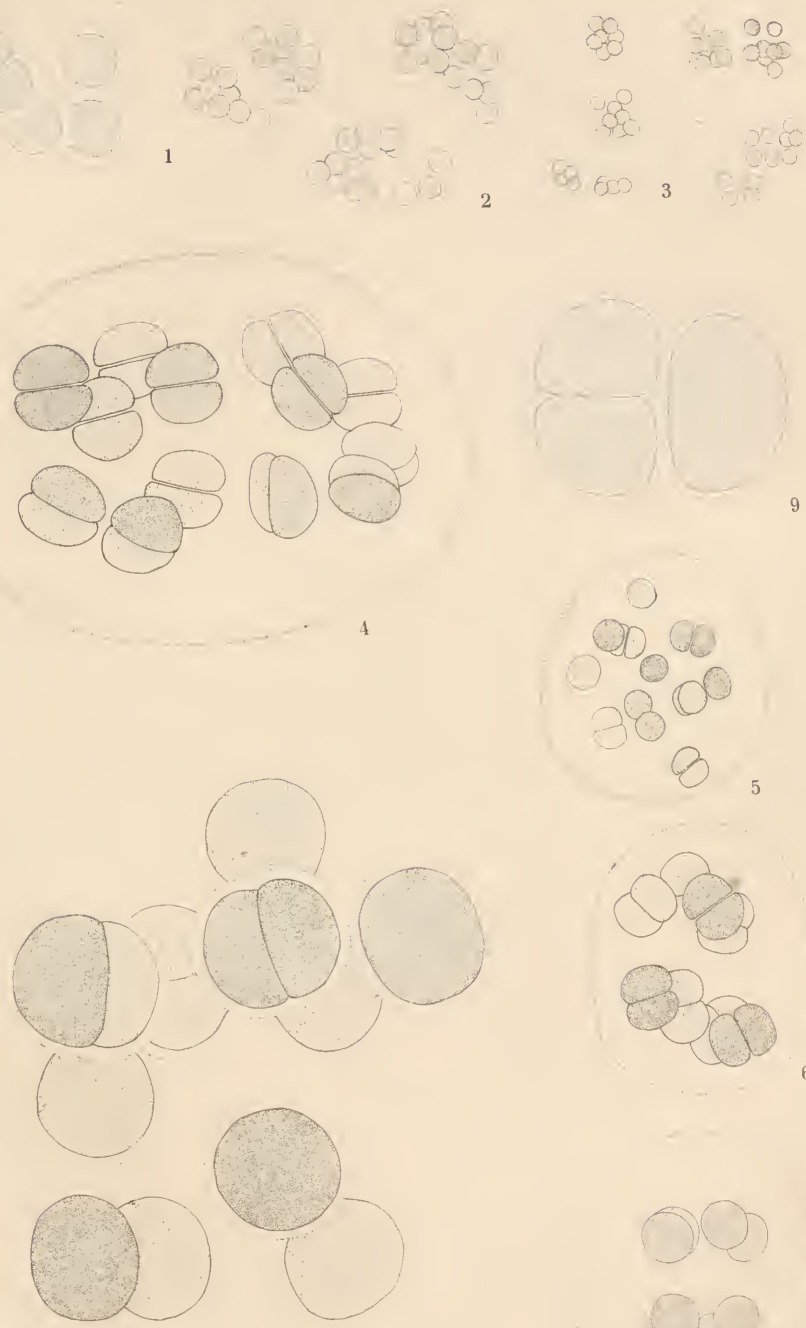

5
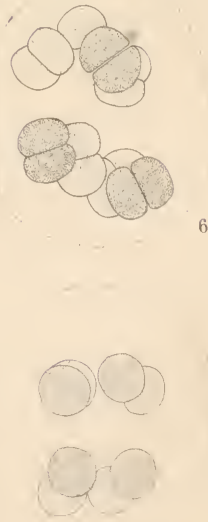

8 

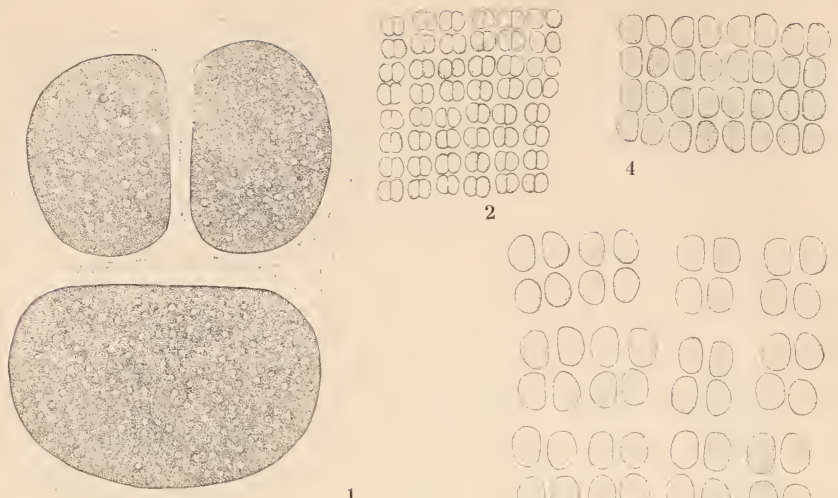

2

\section{1}
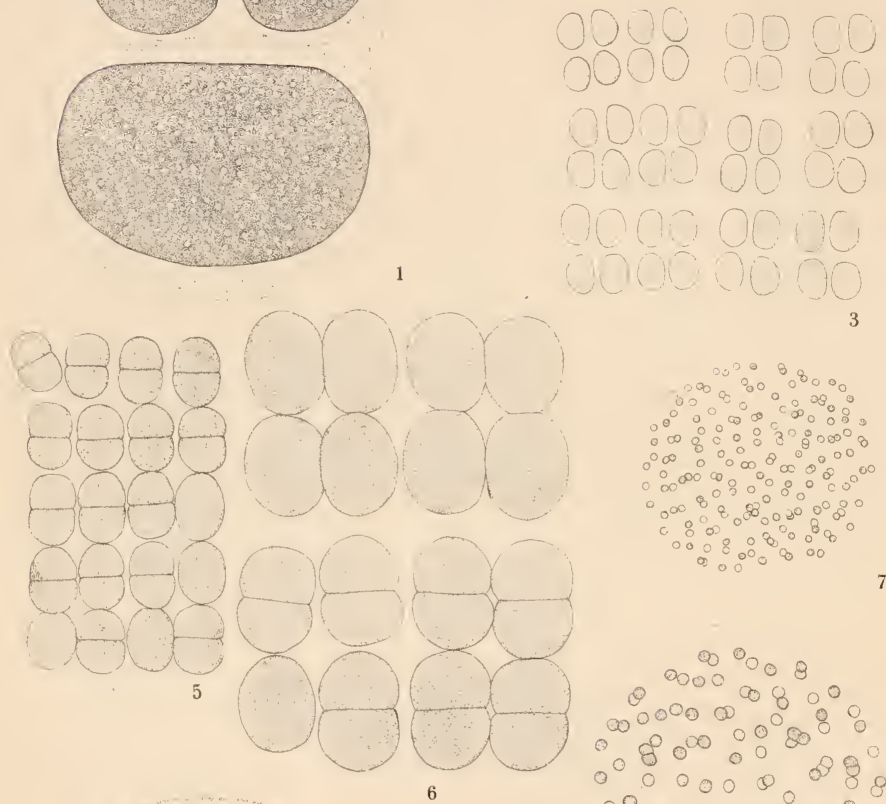

10800

$000^{\circ} 0^{\circ} 00$ - 80 do 0.80 0000 $00^{\circ}, 0_{0}^{\circ} 00$ 00000000

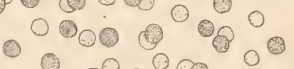
$00^{\circ} 8000$
200

(32) ${ }^{\circ} 0_{0}^{0} 00_{0}^{0} 0^{0} 8$
- $\infty 00008$

$0.80^{\infty} 0_{0}^{0}$
$0.00^{0}$ 0.000000088 $088_{0}^{0} 0.80_{0}^{0}$ $0^{\circ} \infty 0_{0}^{\circ} 0^{\circ} 00^{\circ}$ $80_{0}^{\infty} 0_{0}^{0} 00$

8 


\section{PLATE 2.}

Page

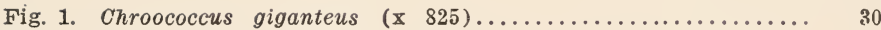

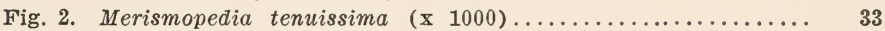

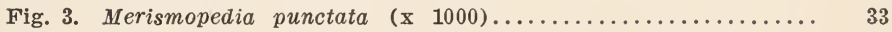

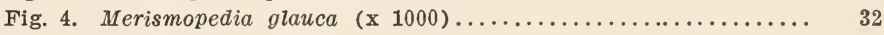

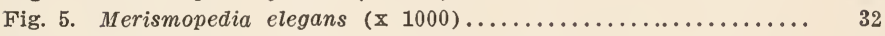

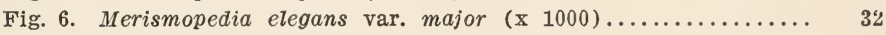

Fig. 7. Aphanocapsa delicatissima (x 1000).................. 41

Fig. 8. Aphanocapsa elachista var. conferta. (x 1000).......... 42

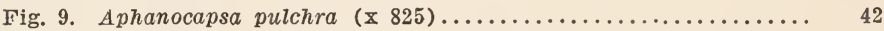

Fig. 10. Aphanocapsa endophytica (x 1000)..................... 42 


\section{PLATE 3.}

Page

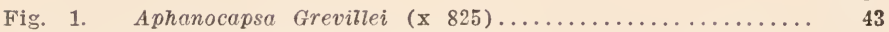

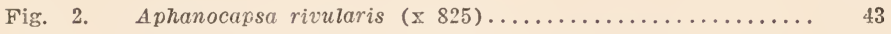

Fig. 3. Aphanocapsa elachista var. planctonica $(\mathrm{x} 1000) \ldots \ldots \ldots .4$. 4 ?

Figs. 4-5. Coelosphaerium Kuetzingianum (x 825).............. 34

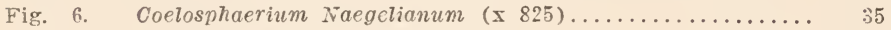

Fig. 7. Coelosphaerium dubium (x 825) ................. 35 
$080_{0} 9800$

$88^{0} 0800$ 008800080 - 0090888090 8000008008

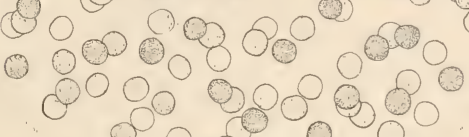
- $800^{\circ} 8^{\circ}$ $80^{\circ} 00000$
80000
800000

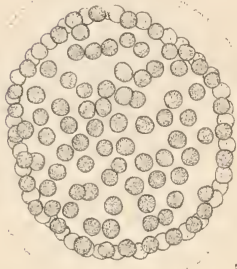

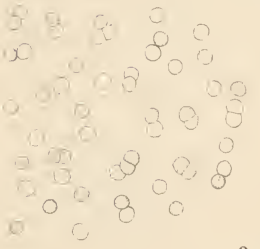
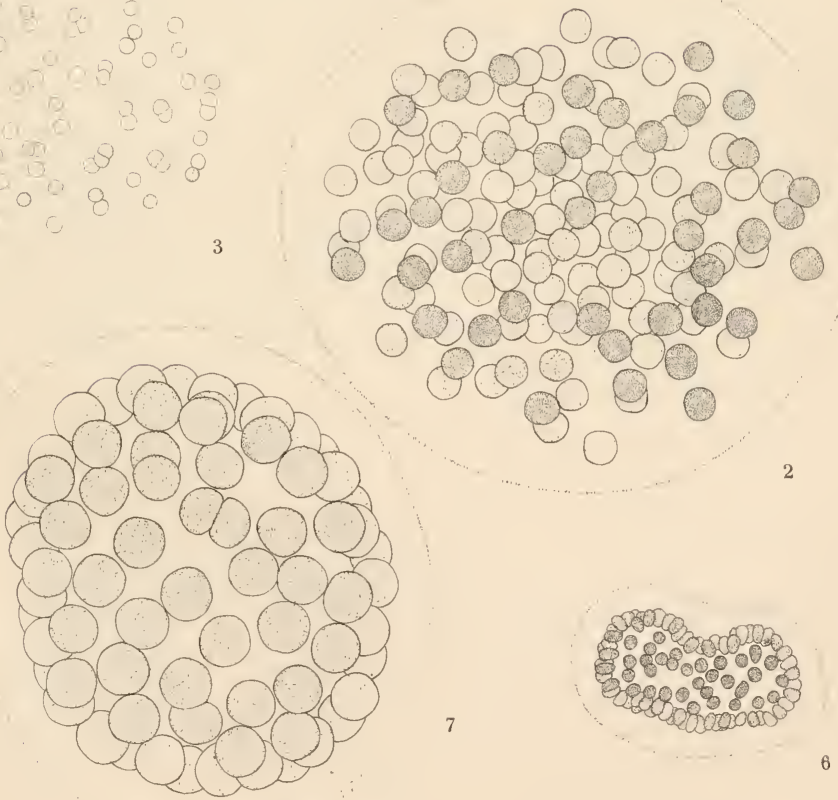

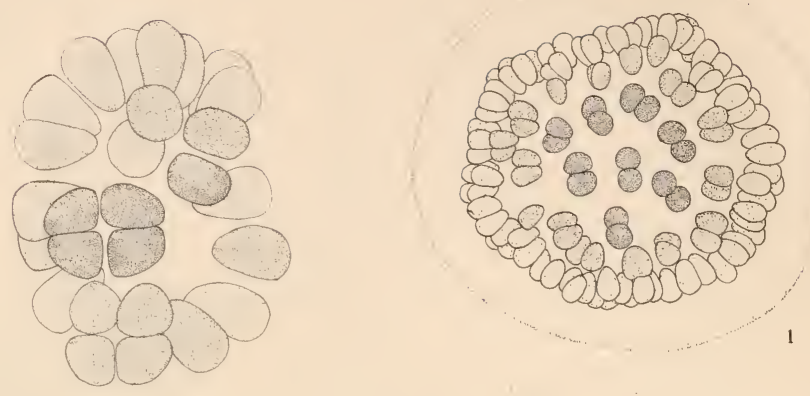

3
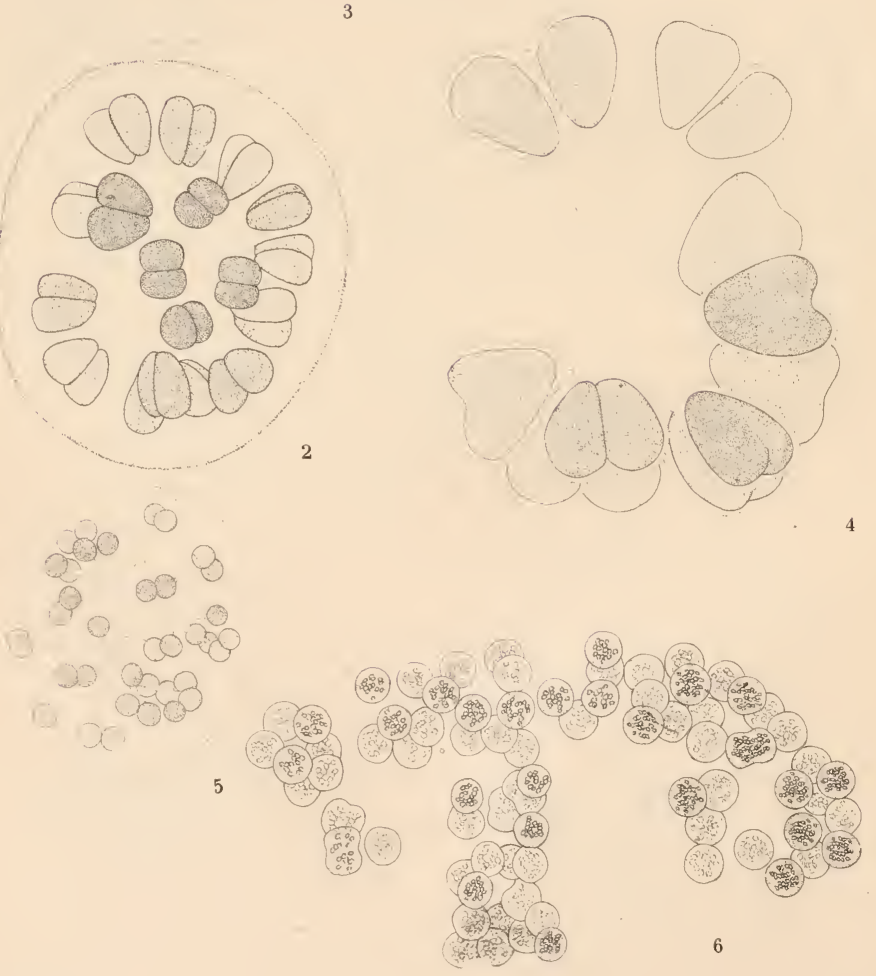
PLATE 4.

Page

Fig. 1. Coelosphaerium Naegelianum (x 825) .............. 35

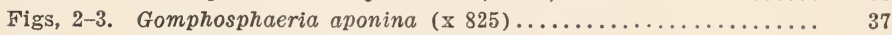

Fig. 4. Gomphosphaeria aponina var. cordiformis (x 825) ....... 37

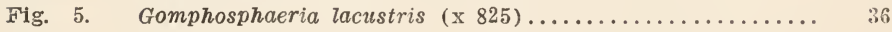

F'ig. 6. Microcystis aeruginosa var. major (x 825$) \ldots \ldots \ldots \ldots \ldots \ldots$. 40 
PLATE 5.

Figs. 1-2. Microcystis aeruginosa (Fig. 1, x 825; fig. 2, x $180 \ldots \ldots \ldots . .39$

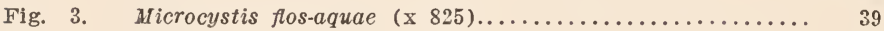

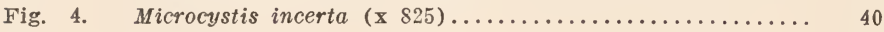

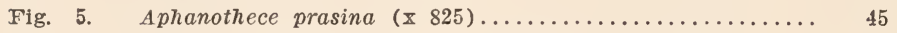

Fig. 6. Aphanothece nidulans var. endophytica (x 1000)........ 44 

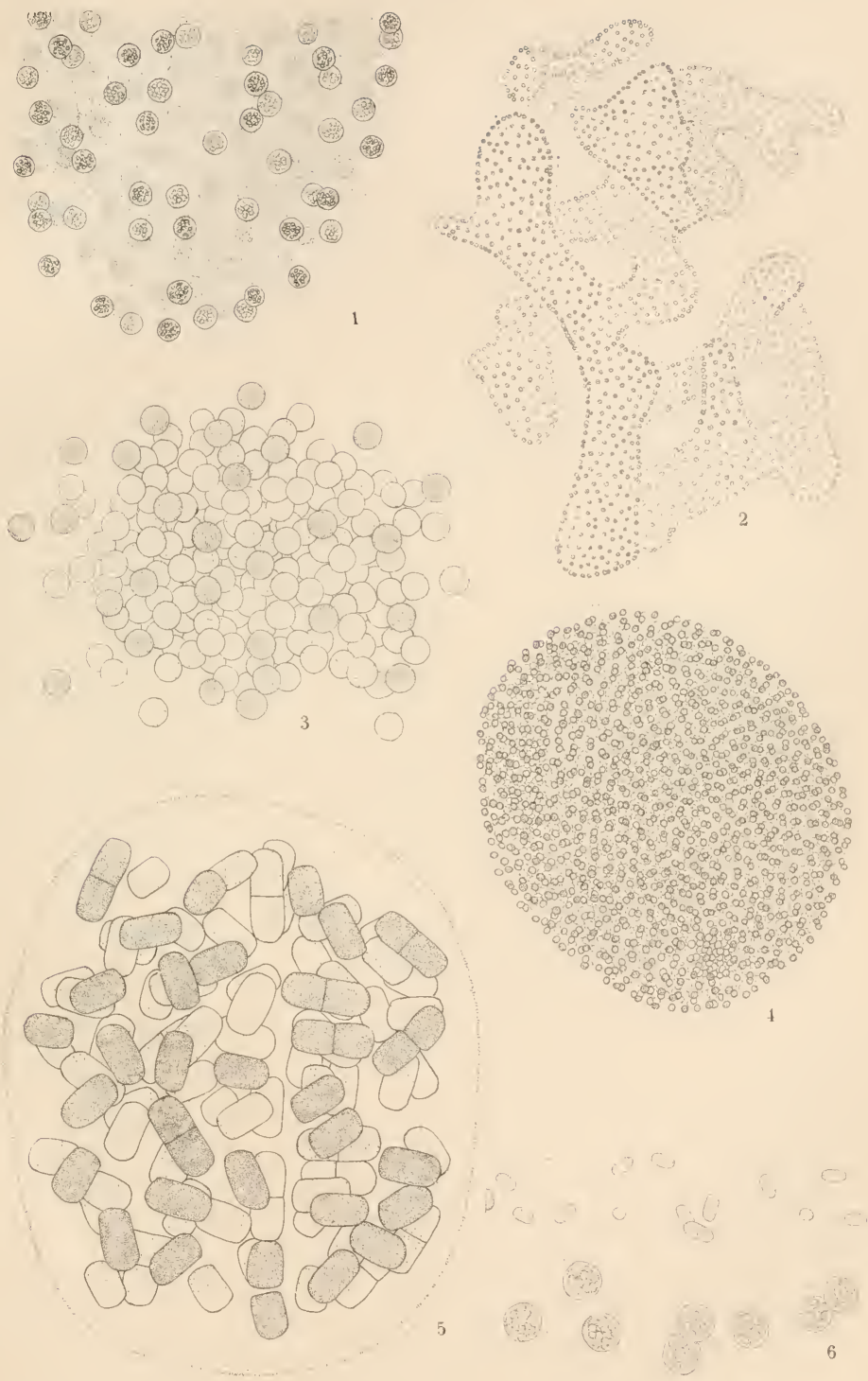

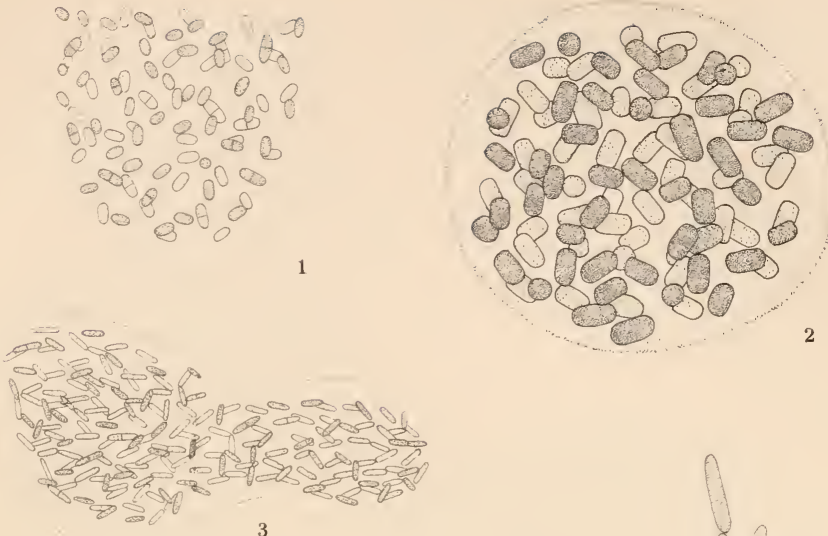

3

5
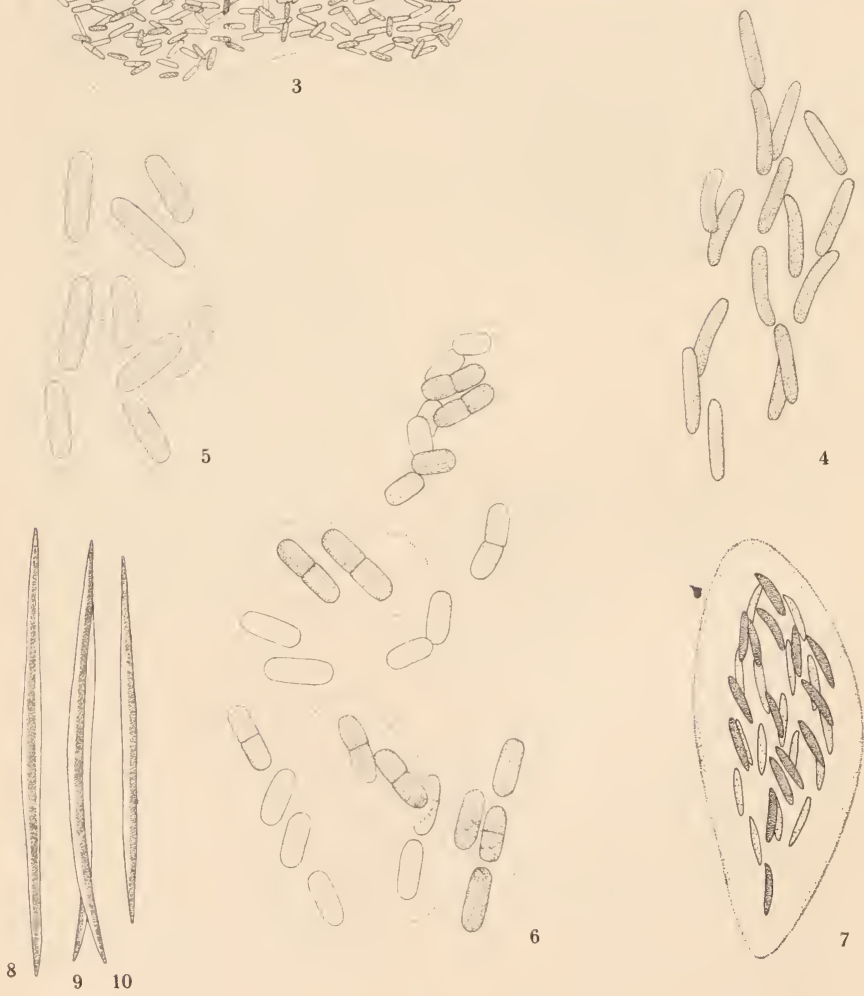
PLATE 6.

Page

Fig. 1. Aphanothece nidulans (x 1000).................... 44

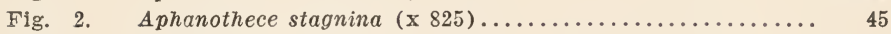

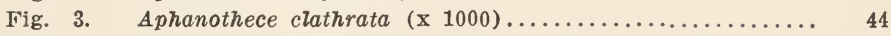

Fig. 4. Rhabdoderma lineare $(\mathrm{x} 1000) \ldots \ldots \ldots \ldots \ldots \ldots \ldots \ldots \ldots \ldots \ldots \ldots \ldots \ldots$

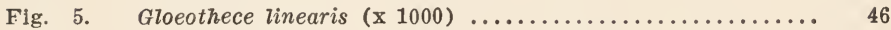

Fig. 6. Gloeothęe linearis var. composita $(\mathrm{x} 1000) \ldots \ldots \ldots \ldots \ldots . \ldots . \ldots$

Fig. 7. Dactylococcopsis raphidioides $(\mathrm{x} 825) \ldots \ldots \ldots \ldots \ldots \ldots \ldots . . \ldots \ldots$

Figs. $8-10$. Dactylococcopsis acicularis $(\mathrm{x} 1000) \ldots \ldots \ldots \ldots \ldots \ldots \ldots . .48$ 


\section{PLATE 7.}

Page

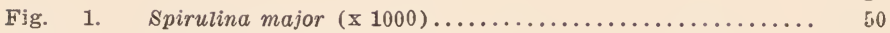

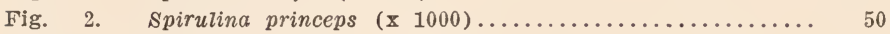

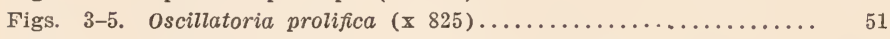

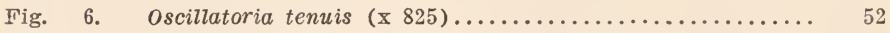

Figs. 7-8. Oscillatoria tenuis var. tergestina $(x \quad 825) \ldots \ldots \ldots \ldots \ldots \ldots, 52$

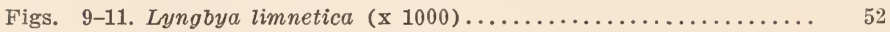

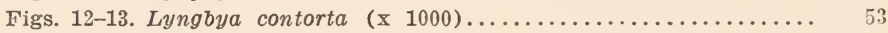

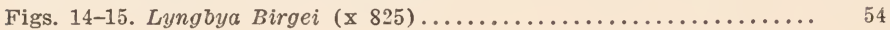



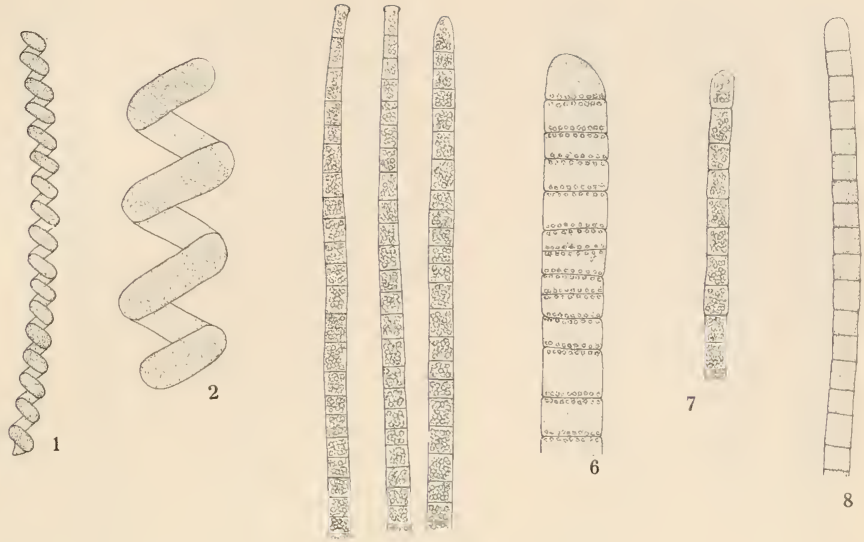

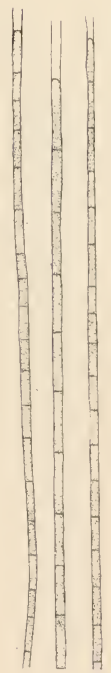

$\begin{array}{lll}9 & 10 & 11\end{array}$
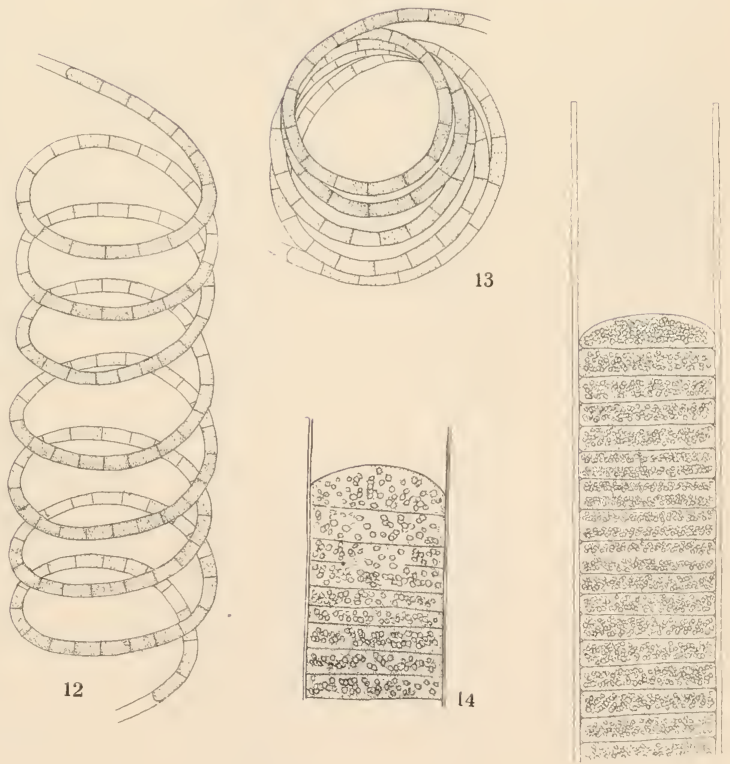

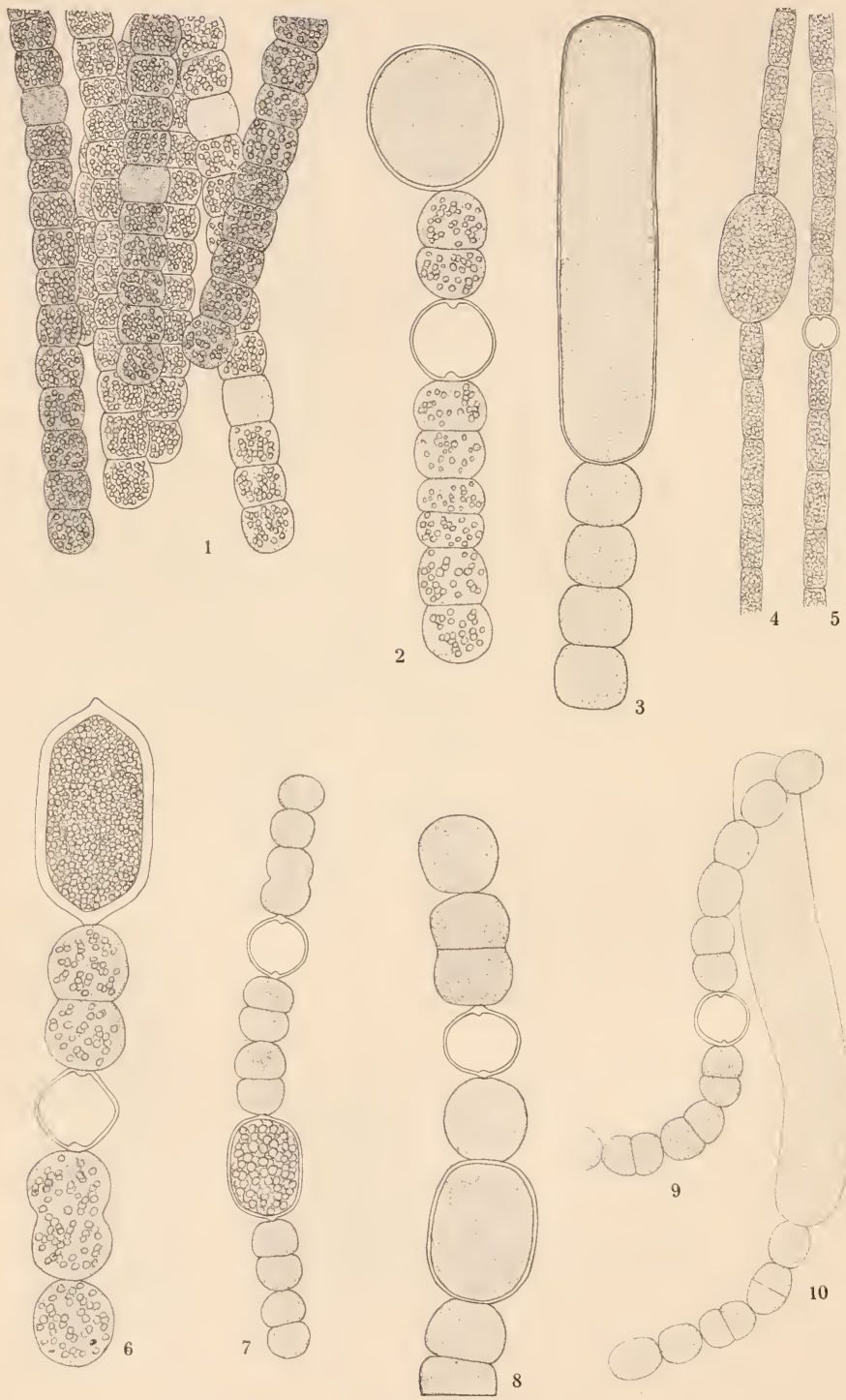
PLATE 8.

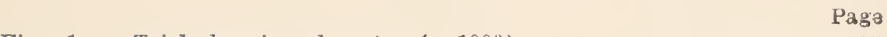

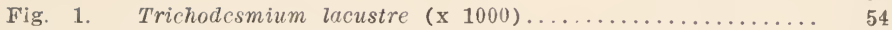

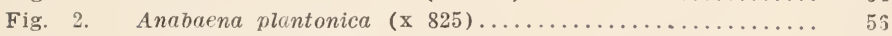

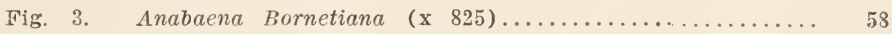

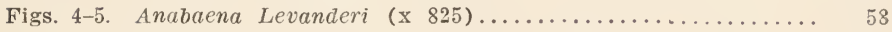

Fig. 6. Anabaena macrospora var. robusta (x 825$) \ldots \ldots \ldots \ldots \ldots . \quad 57$

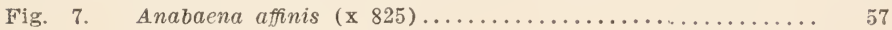

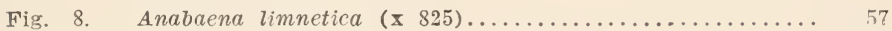

Figs. 9-10. Anabaena augstumalis var. marchica $(x \quad 825) \ldots \ldots \ldots \ldots \ldots . . \ldots 8$

13 
PLATE 9.

Figs. 1-3. Anabaena spiroides var. crassa (Flg. 1, x 825, figs. 2-3, x 400) 59

Figs. 4-5. Anabaena circinalis (Fig. 4, × 825, fig. $5, \times 400$ )........ 59

Fig. 6. Anabaena circinalis var. macrospora $(\mathrm{x} 825) \ldots \ldots \ldots \ldots \ldots .60$ 


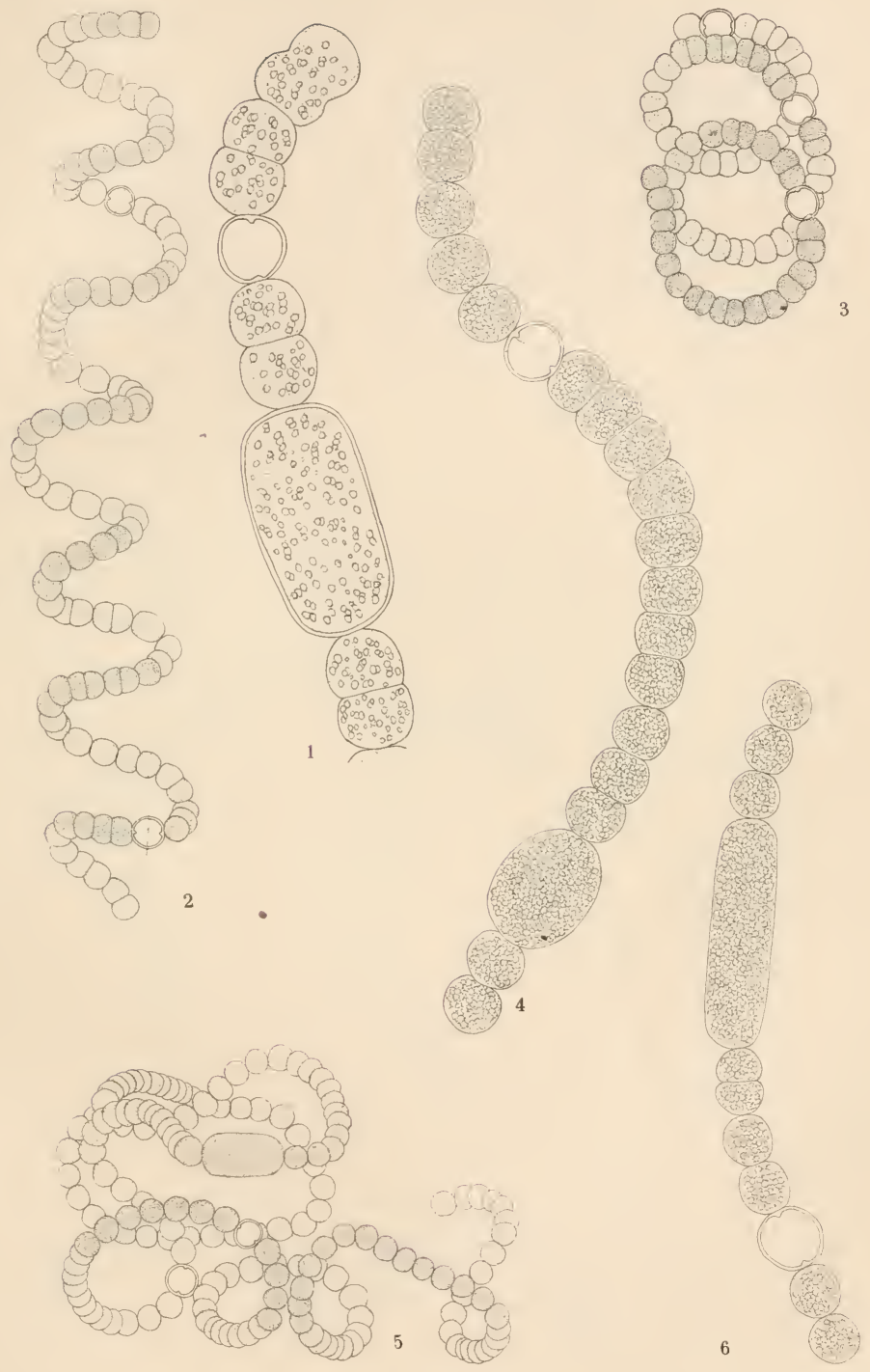




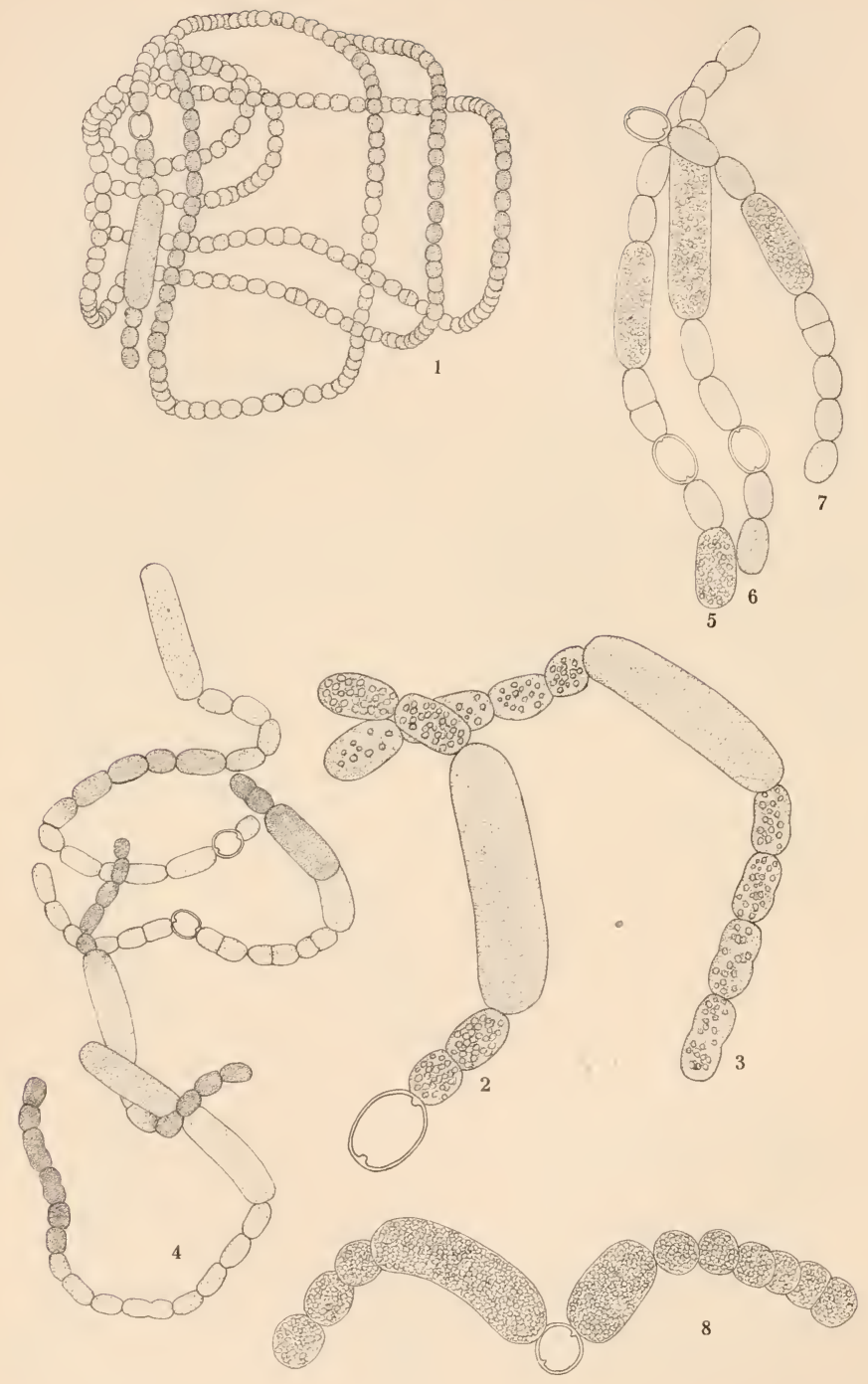


PLATE 10.

Page

Fig. 1. Anabaena circinalis var. macrospora $(\mathrm{x} 400) \ldots \ldots \ldots \ldots \ldots .60$

Figs. 2-4. Anabaena flos-aquae (Figs. 2-3, x 825; fig. 4, x 400 )....... 60

Figs. 5-7. Anabaena flos-aquae var. Treleasii (x 825) ............. 60

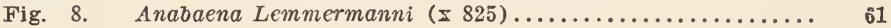




\section{PLATE 11.}

Page

Fig. 1. Anabaena Lemmermanni (x 400)......................... 61

Figs. 2-4. Aphanizomenon flos-aquae (Fig. 2, x 400; figs. 3-4, x 1000).. 61

Figs. 5-6. Gloeotrichia echinulata $(\mathrm{x} 400) \ldots \ldots \ldots \ldots \ldots \ldots \ldots \ldots \ldots \ldots \ldots \ldots$ 


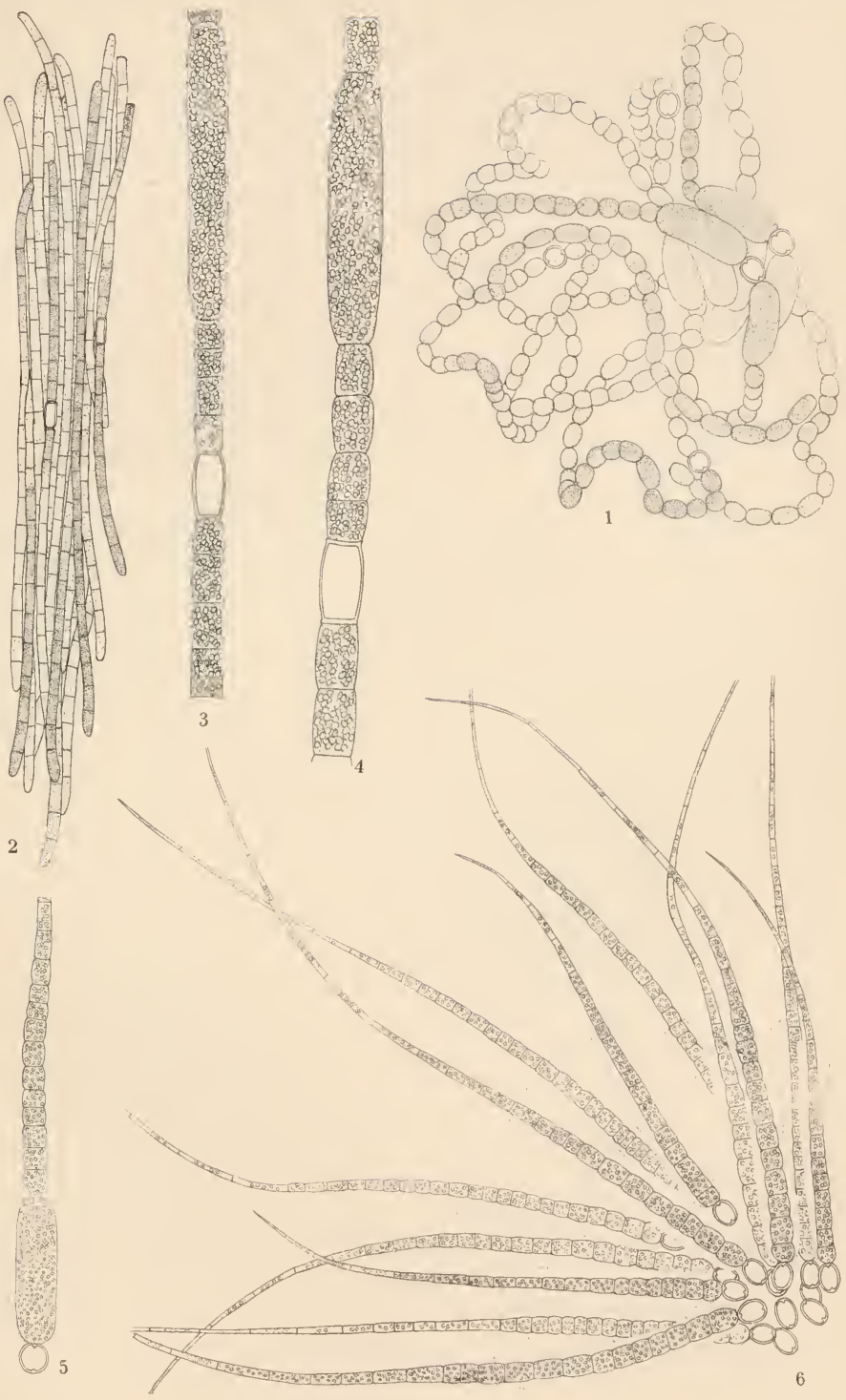




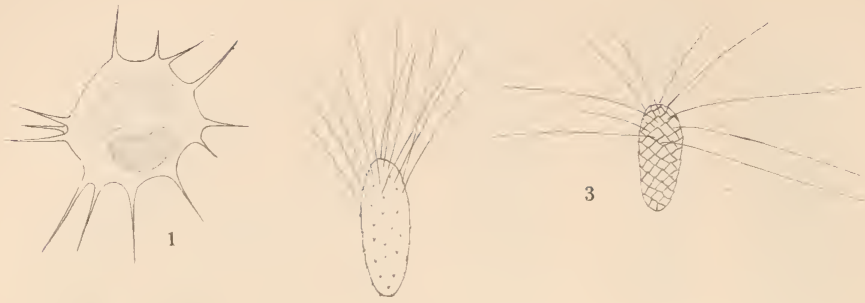

2

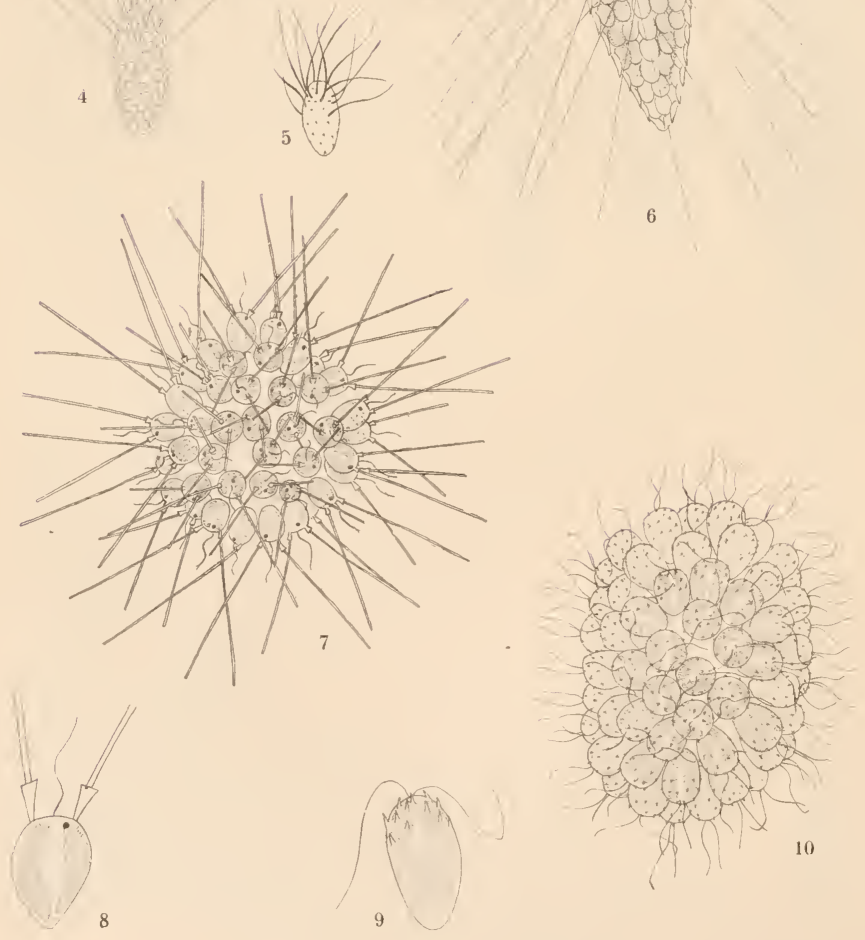


PLATE 12.

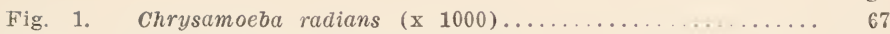

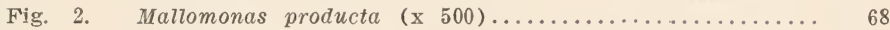

Fig. 3. Mallomonas producta var. marchica (x 500).......... 68

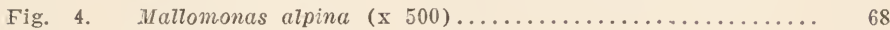

Fig. 5. Mallomonas tonsurata (x 500$) \ldots \ldots \ldots \ldots \ldots \ldots \ldots \ldots \ldots . \ldots \ldots$

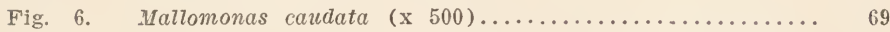

Figs. 7-8. Chrysosphaerella longispina (Fig. 7, x 400; fig. 8, x 1000).. 69

Figs. 9-10. synura uvella (Fig. 9, x 1000, fig. 10, x 400$) \ldots \ldots \ldots \ldots$. 70 
PLATE 13. Figs. 1-4. Uroglenopsis americana (Fig. 1, x 400; figs. 2-4, × 1000)... 71

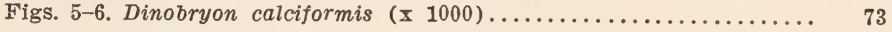

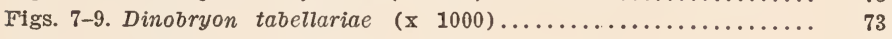

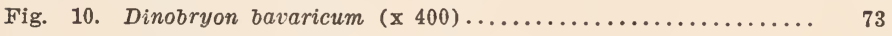

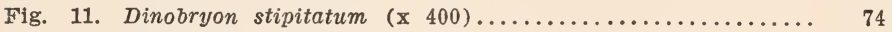

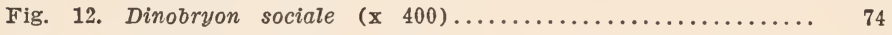

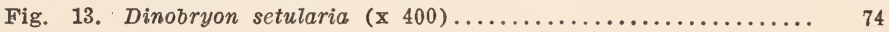




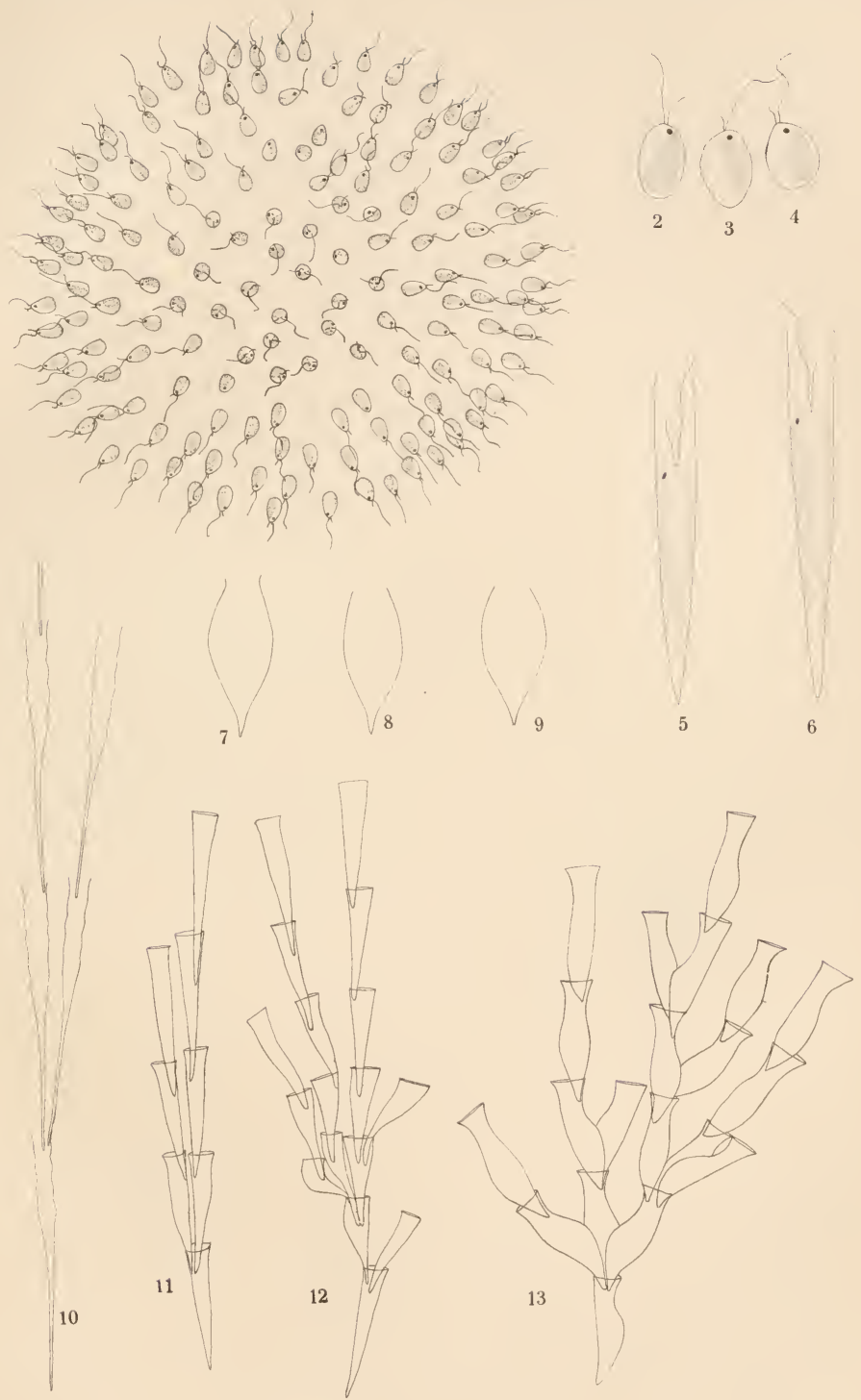


WISCONSIN SURVEY

BULLETIN 57, PLATE I4
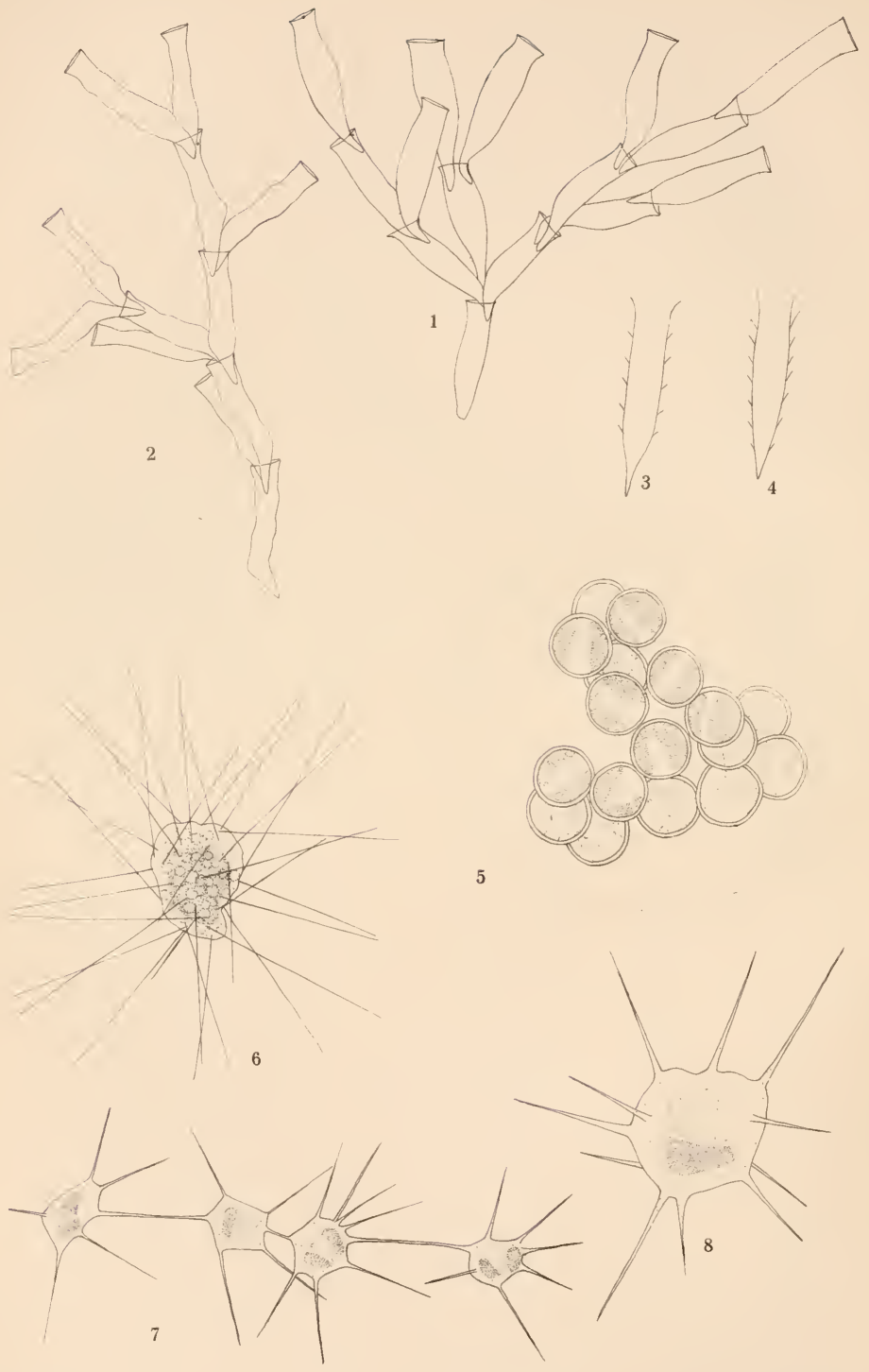

SMITH-ALGAE 
PLATE 14.

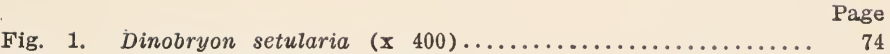

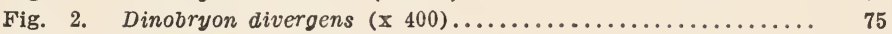

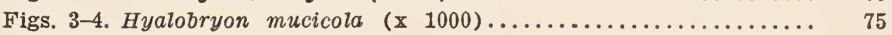

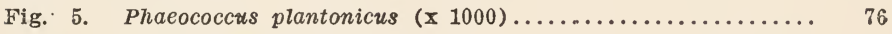

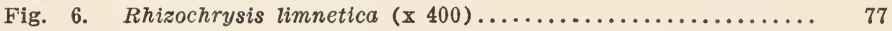

Figs. 7-8. Chrysidiastrum catenulatum (Fig. 7, × 500, fig. 8, × 1000).. 78 
PLATE 15.

Fage

Figs: 1-3. Chlorochromonas minuta (x 1000)................. 80

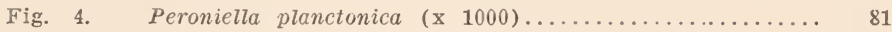

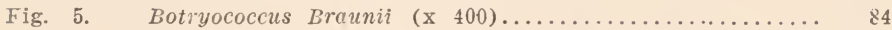

Figs. 6-7. Botryococcus protuberans var. minor (Fig. 6 × 500, fig. $7 \mathrm{x}$

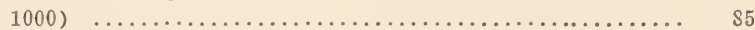

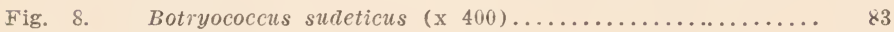

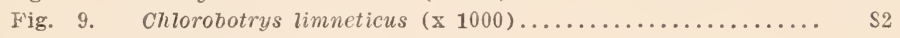

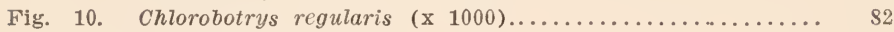

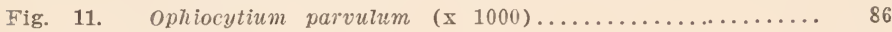

Figs. 12-13. Ophiocytium capitatum (x 1000).................. 86

Figs. 14-16. Ophiocytium capitatum var. longispinum (x 1000)........ 86

Figs. 17-18. Tribonema minus (x 1000).................... 87 


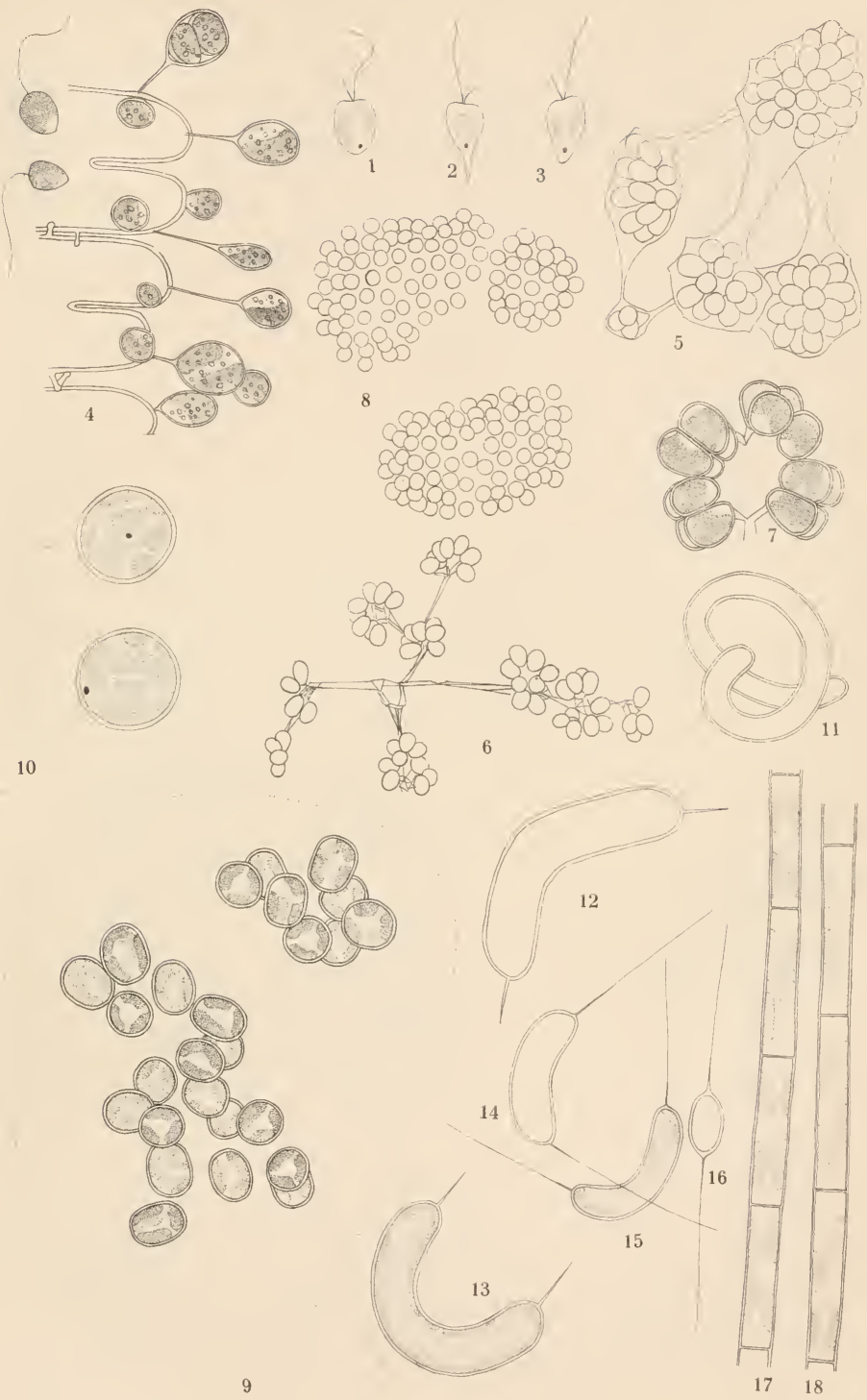




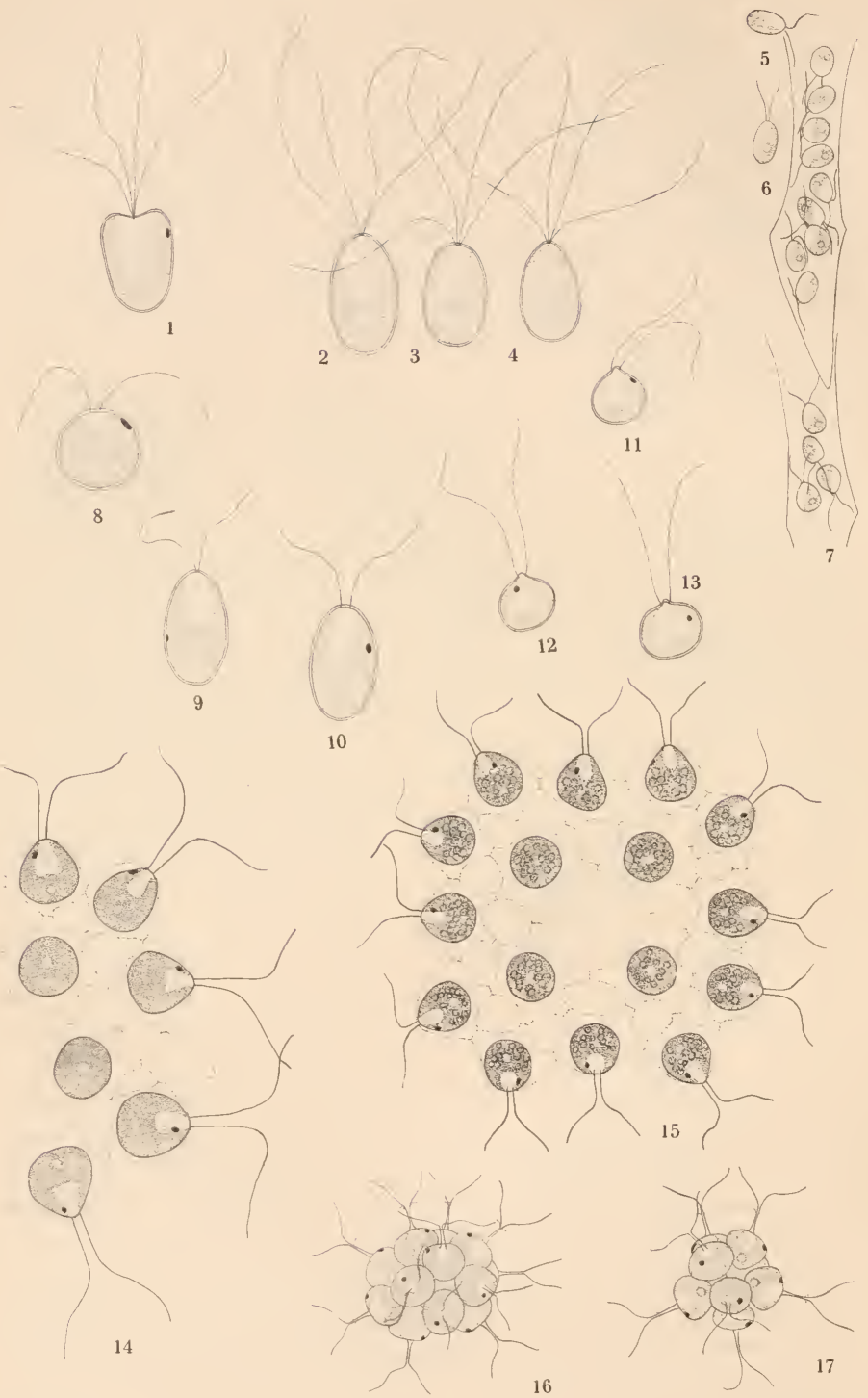




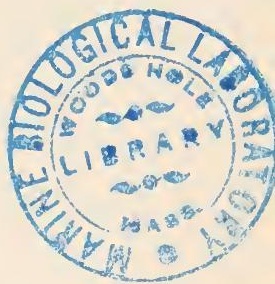

PLATE 16.

Page

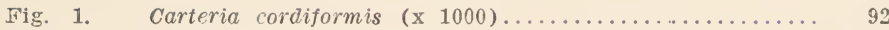

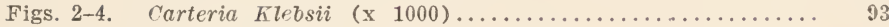

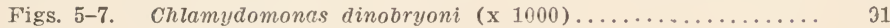

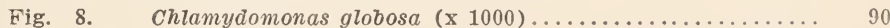

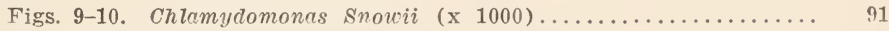

Figs. 11-13. Chlamydomonas epiphytica $(\mathrm{x} 1000) \ldots \ldots \ldots \ldots \ldots \ldots \ldots . \ldots \ldots$

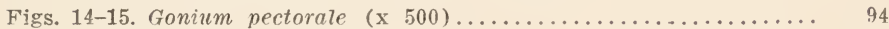

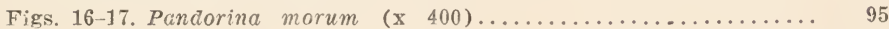


PLATE 17.

Figs. 1-3. Pleodorina californica (x 400) 


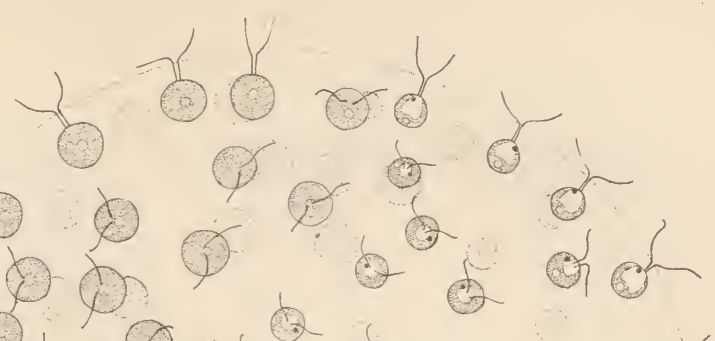

+00 क क बर

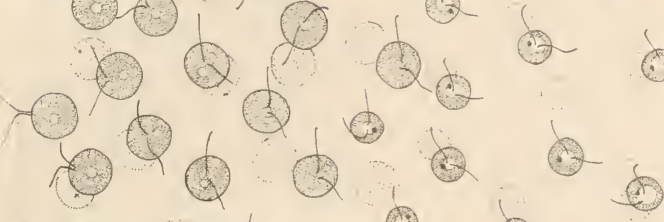

$+Q d \theta^{a}$ $0^{Q} Q Q^{Q} Q$

P Q $99^{9}$

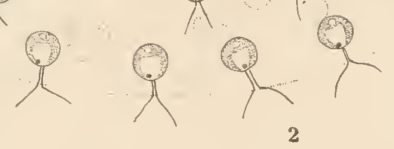

(3) 0 a d

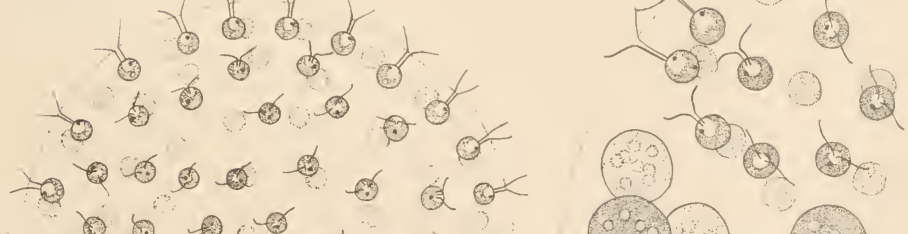
to 6 \% क व $+\theta \%$ o 9

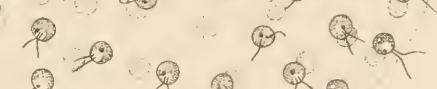
- $P$ \& $Q^{2}$
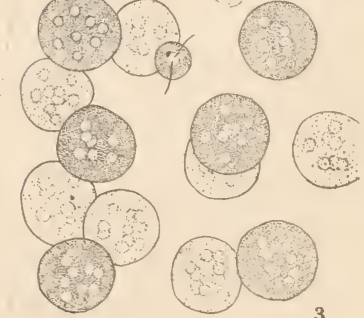


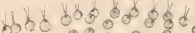

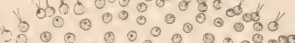

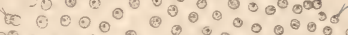

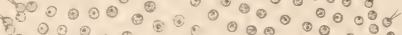

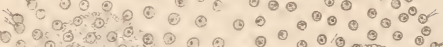

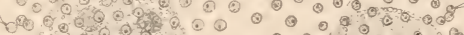

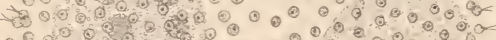

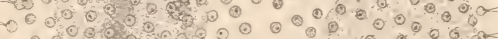

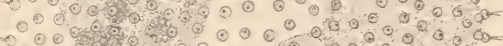

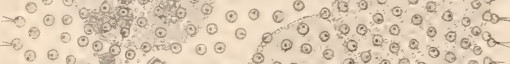

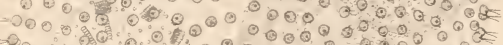

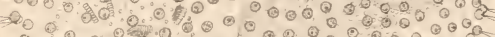

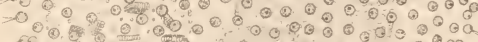

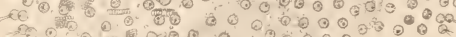
यद 0 a

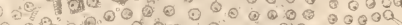

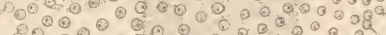

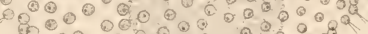

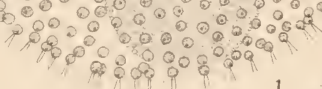

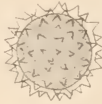

4

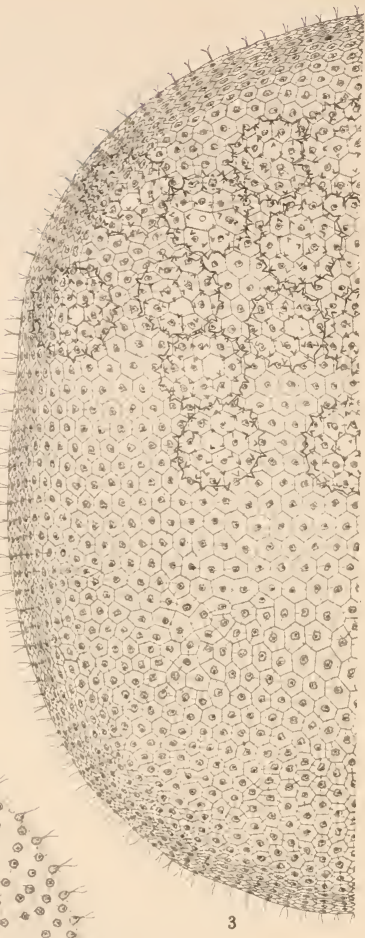

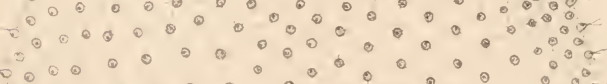

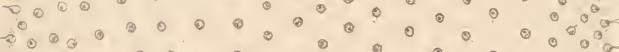

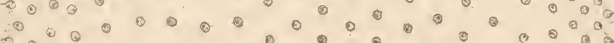

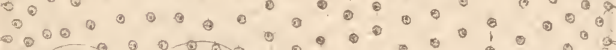

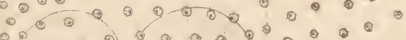

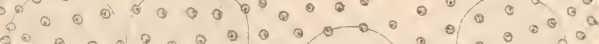

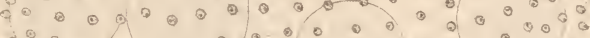

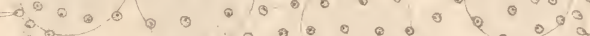

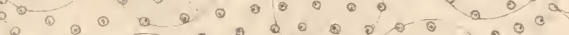

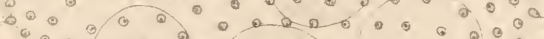

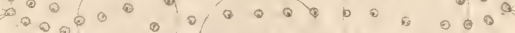

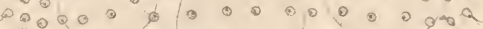

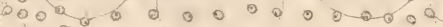

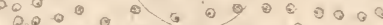

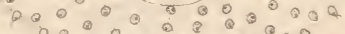

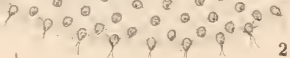

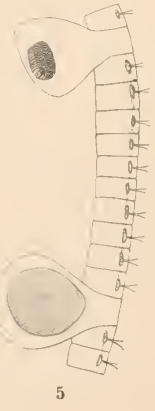


PLATE 18.

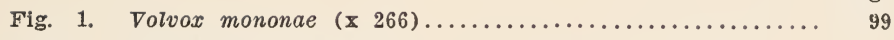

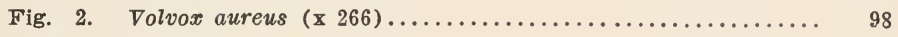

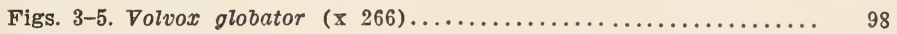


PLATE 19.

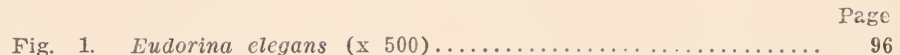

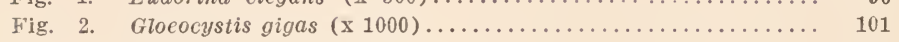

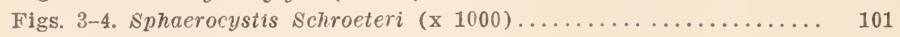

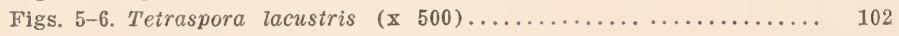



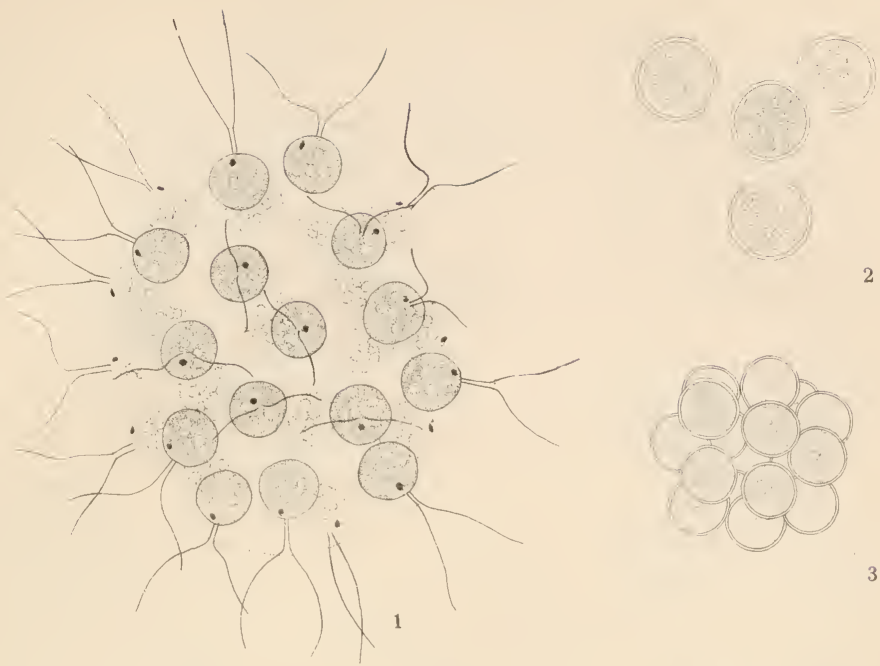

$\$ 6$
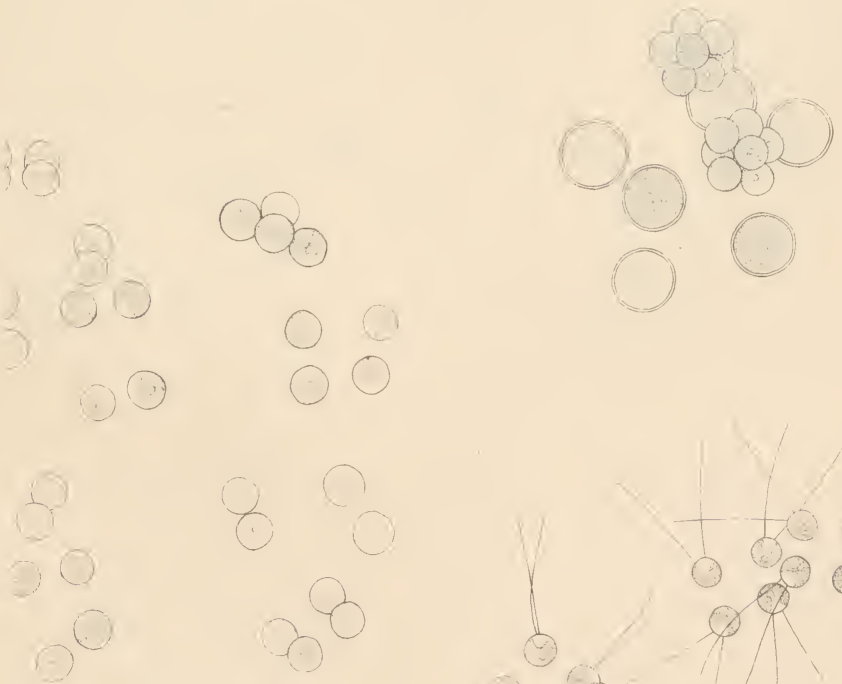

5

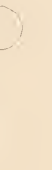



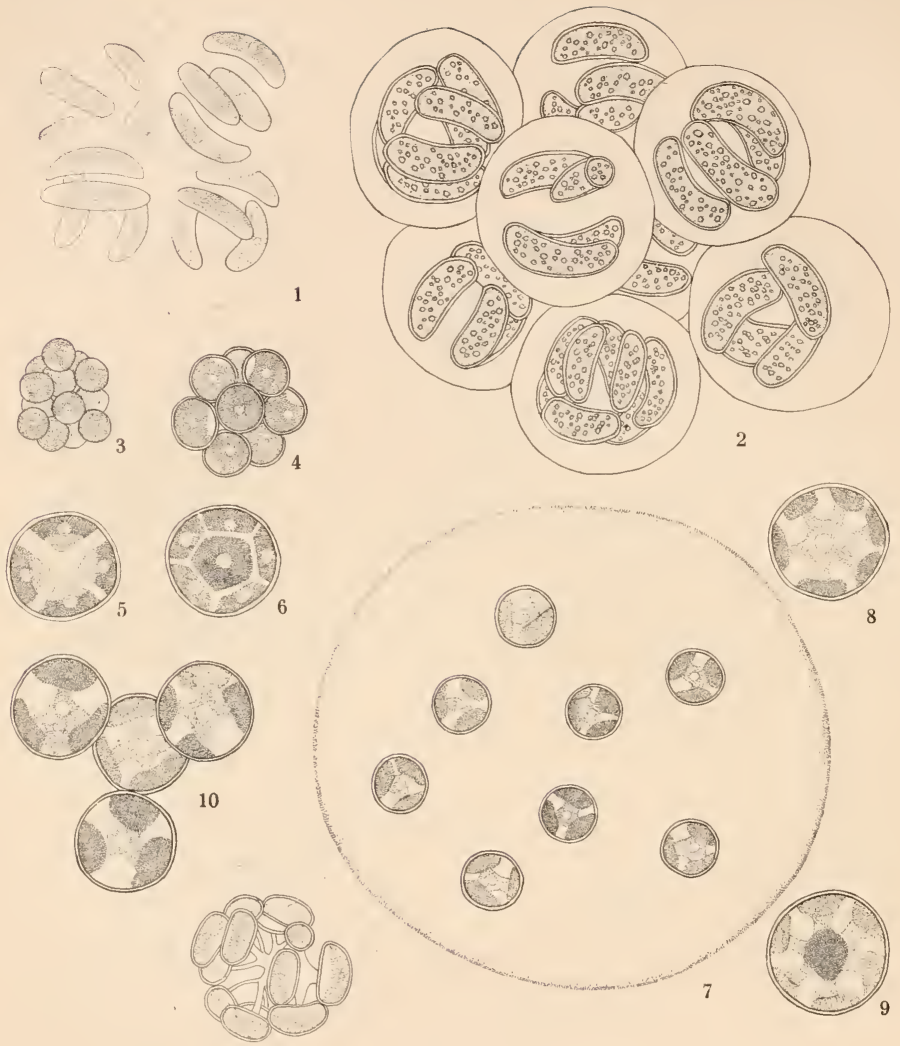

11
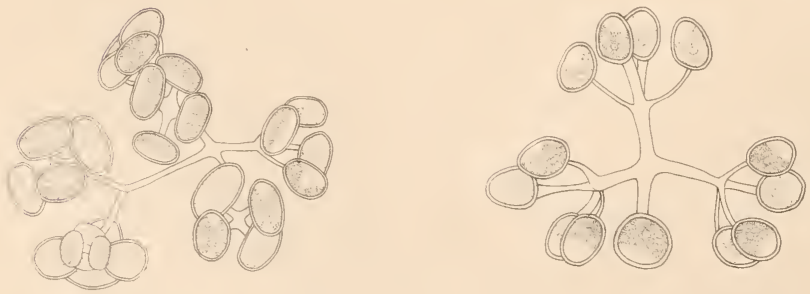
PLATE 20.

Figs. 1-2. Gloeocystopsis limneticus $(x$ 1000).............. 103

Figs. 3-6. Planktosphaeria gelatinosa (x 1000)............... 103

Figs. 7-10. Asterococcus limneticus (Fig. 7, x 500; figs. 8-10, x 1000). 104

Figs. 11-12. Dictyosphaerium Ehrenbergianum (x 1000) ......... 105

Fig. 13. Dictyosphaerium pulchellum $(x$ 1000)............ 105 


\section{PLATE 21.}

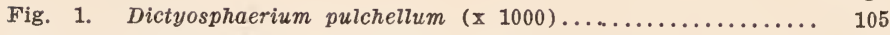

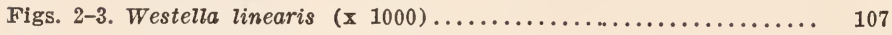

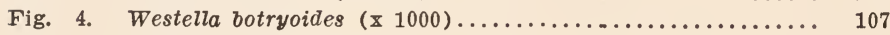

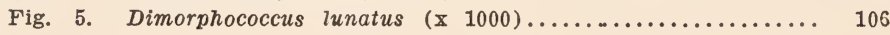



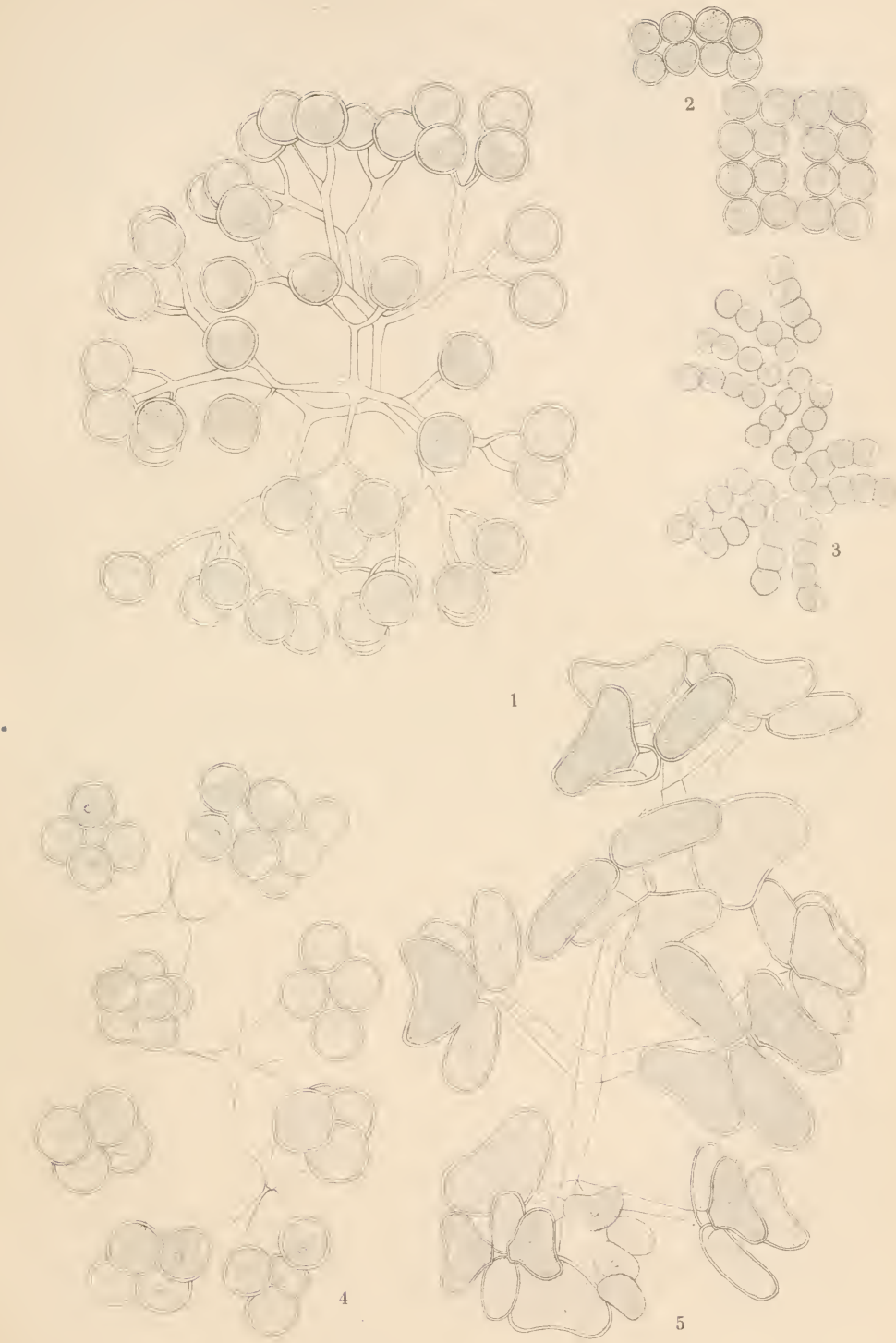


$$
\begin{aligned}
& \overline{9} \cdot 0 . \overline{80} \\
& \text { (2). } 8 \\
& \text { (62) (88) } 90 \\
& 0000
\end{aligned}
$$


PLATE 22.

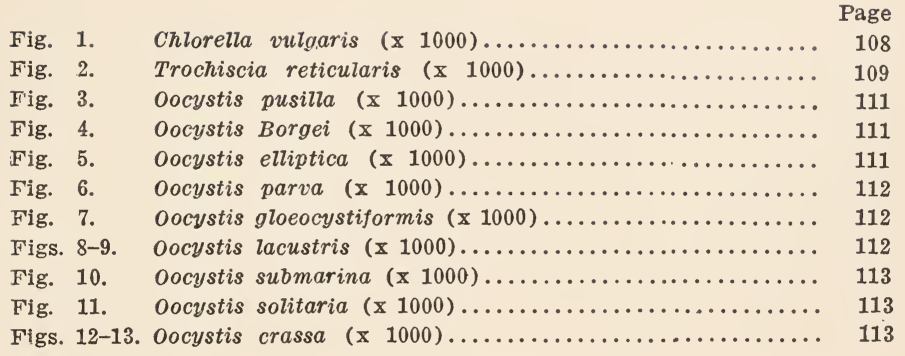


PLATE 23.

F'igs. 1-2. Oocystis eremosphaeria (x 1000).................... 113

Fig. 3. Oocystis panduriformis var. minor $(x 1000) \ldots \ldots \ldots \ldots .114$

Figs. 4-5. Oocystis natans var. major (Fig. 4, x 500; fig. 5, x 1000).. 114

Figs. 6-7. Nephrocytium Agardhianum (x 1000).............. 114

Figs. 8-9. Gloeotaenium Loitlesbergerianum $(x-400) \ldots \ldots \ldots \ldots \ldots . \quad 115$

Figs. 10-13. Tetraëdron muticum var. punctulatum (x 1000)....... 116

Figs. 14-16. Tetraëdron trigonum (x 1000)................... 116 

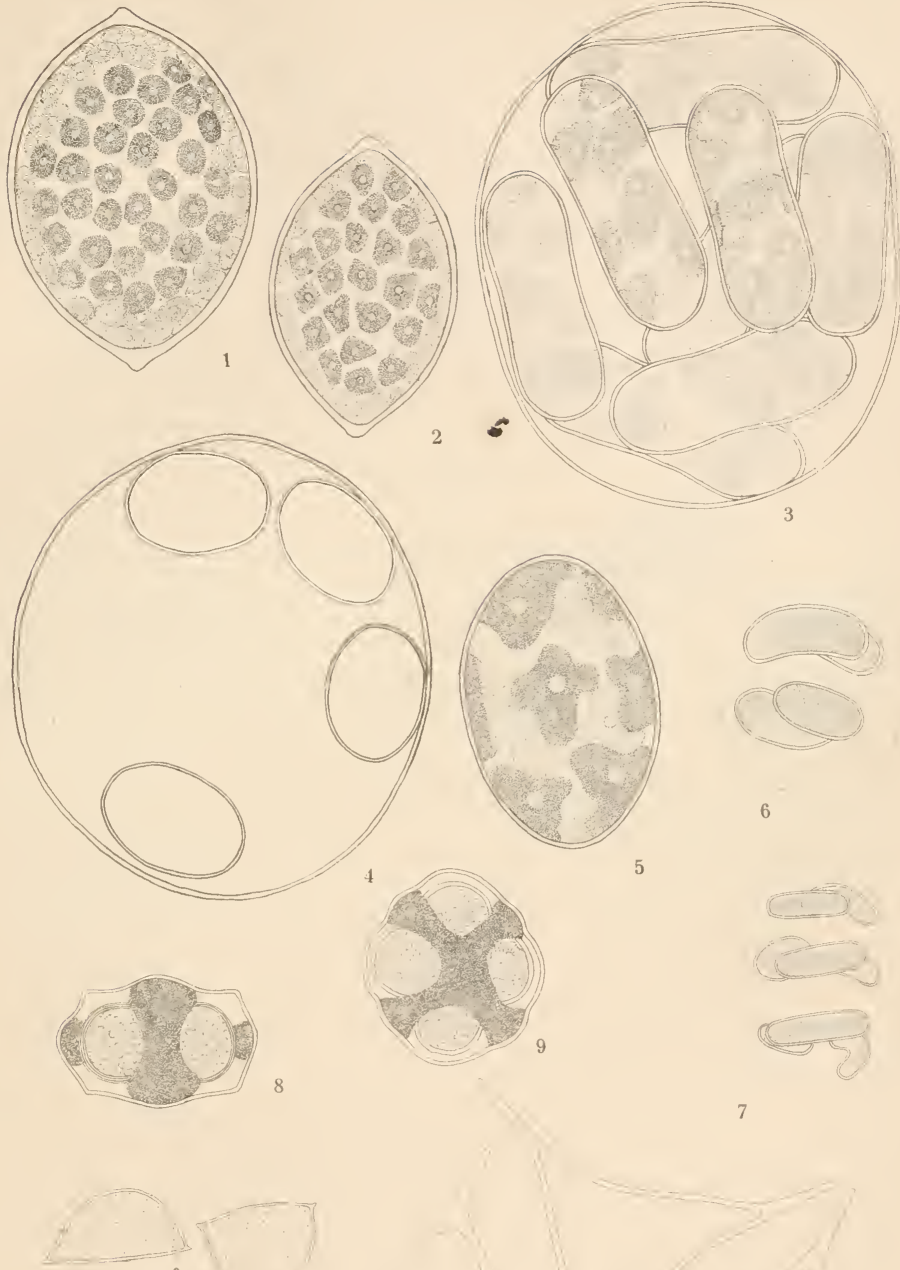

10 


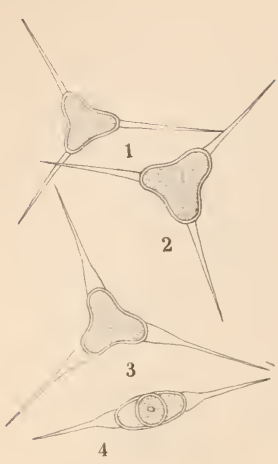

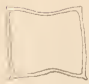

10
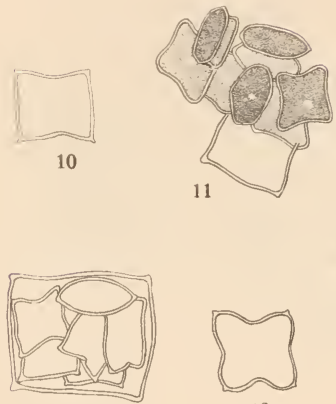

12

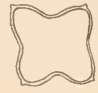

13
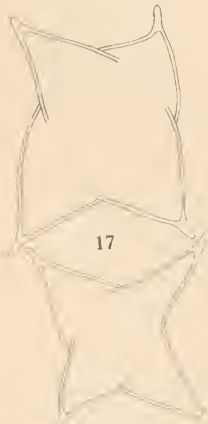

18

19

20
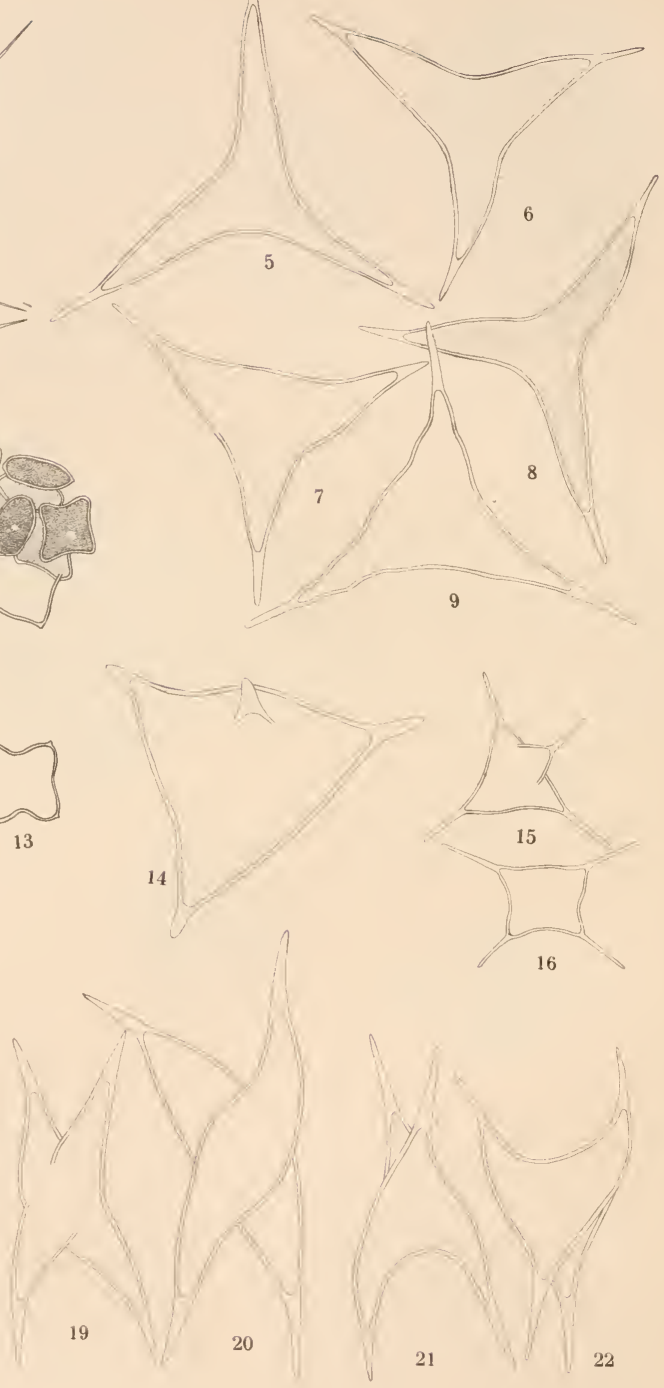


\section{PLATE 24.}

Page

Figs. 1-4. Tetraëdron trigonum var. setigerum $(x 1000) \ldots \ldots \ldots \ldots \ldots$.

Figs. 5-9. Tetraëdron trigonum var. gracile (x 1000) ............ 117

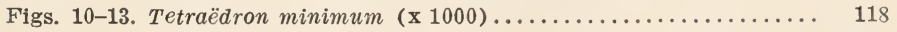

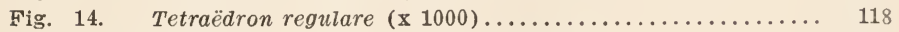

Figs. 15-16. Tetraëdron regulare var. incus $(x 1000) \ldots \ldots \ldots \ldots \ldots \ldots \ldots, 118$

Figs. 17-18. Tetraëdron regulare var. torsum (x 1000) ............. 119

Figs. 19-22.. Tetraëdron victorieae var. major (x 1000)............ 119 


\section{PLATE 25.}

Page

Fig. 1. Teträ̈dron victorieae var. major $(x$ 1000)............ 119

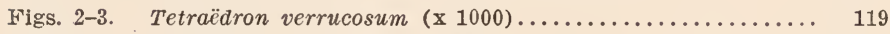

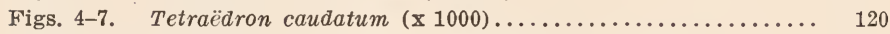

Figs. 8-12. Tetraëdron caudatum var. longispinum (x 1000)......... 120

Figs. 13-17. Tetraëdron pentaëdricum (x 1000).................. 120

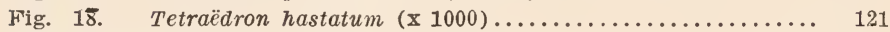

Figs. 19-21. Tetraëdron hastatum var. palatinum (x 1000) ........... 121

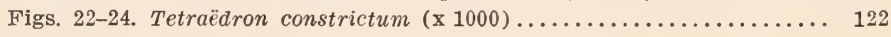




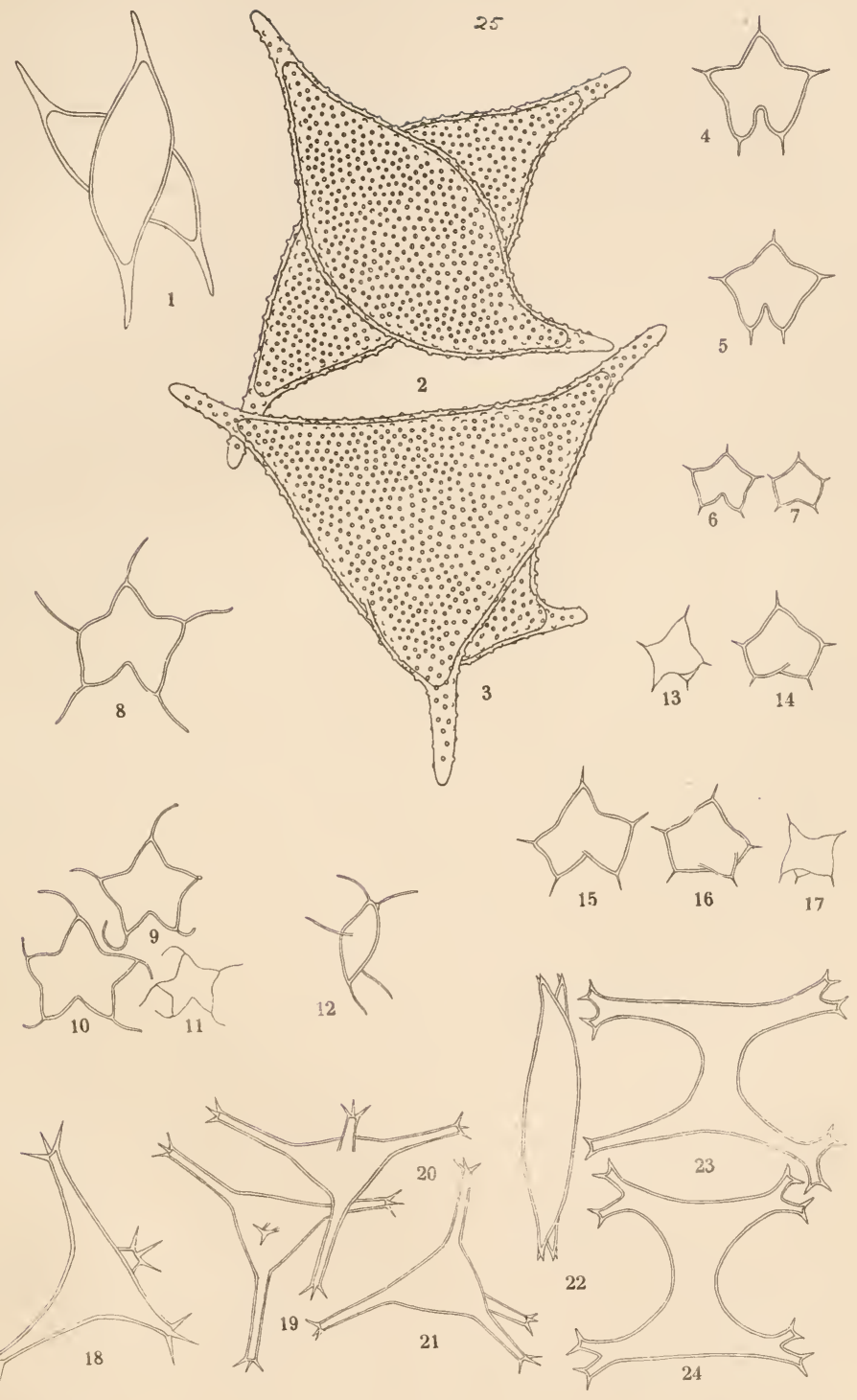




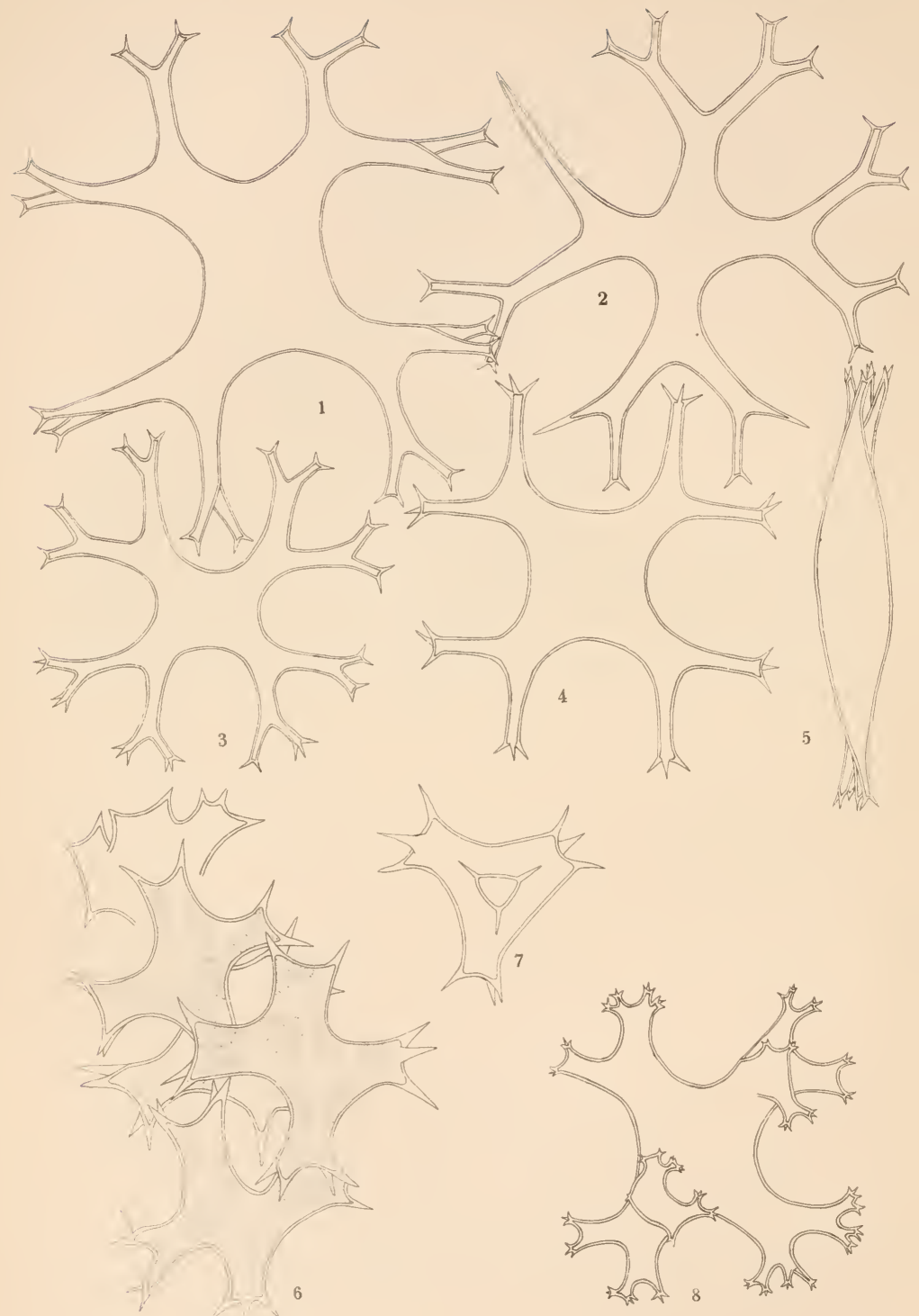


PLATE 26.

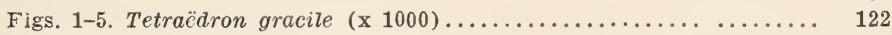

Figs. 6-7. Tetraëdron lobulatum (x 1000)..................... 122

Fig. 8. Tetraëdron lobulatum var. polyfurcatum $\left(\begin{array}{ll}\text { x } 1000\end{array}\right) \ldots \ldots \ldots$ 
PLATE 27.

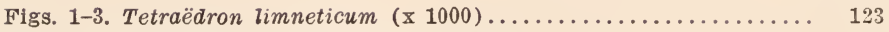

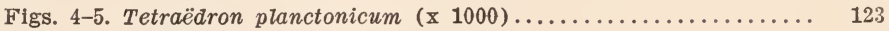

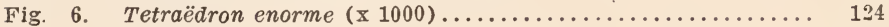

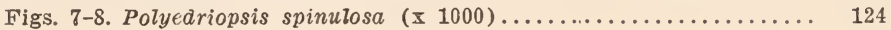




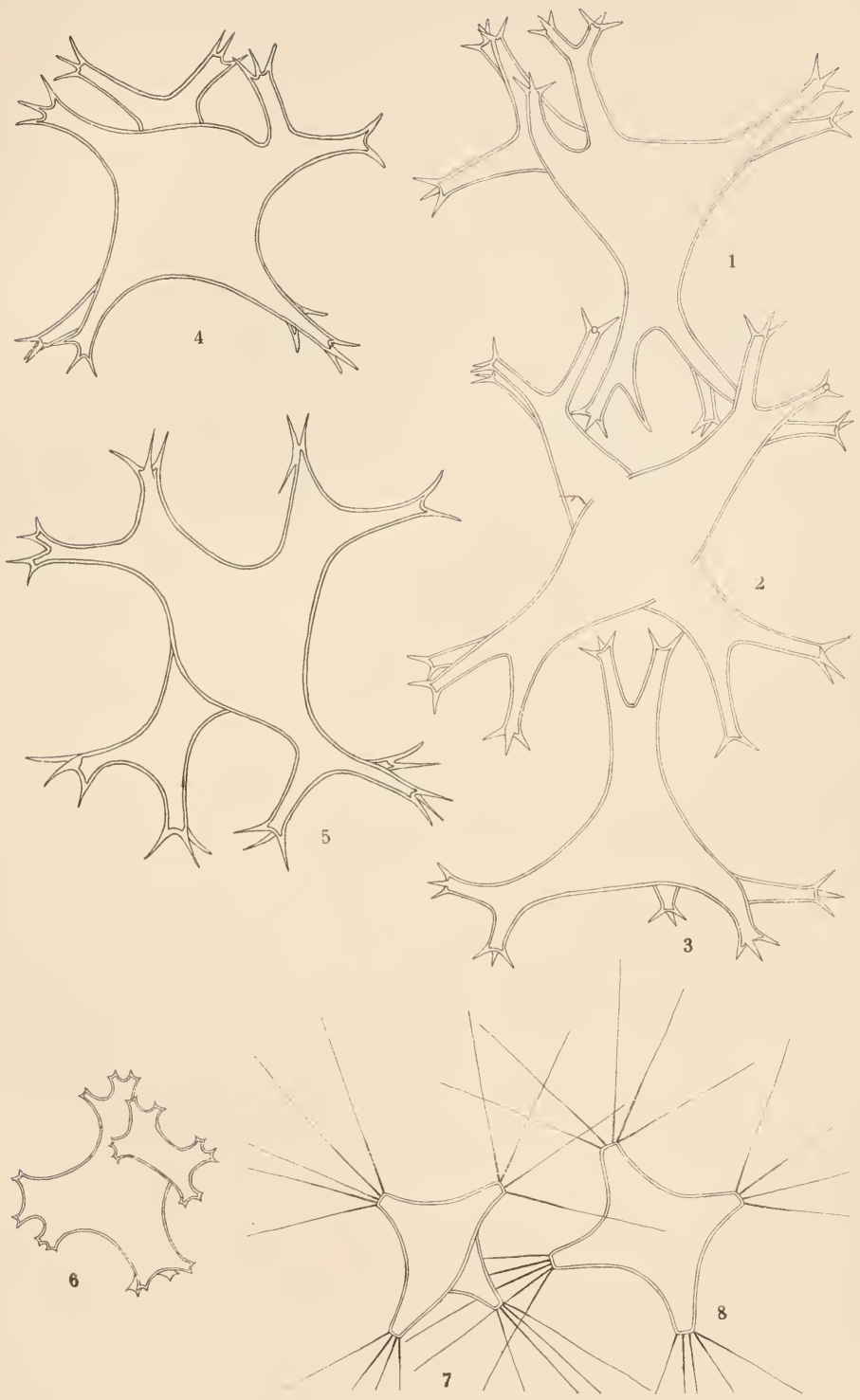




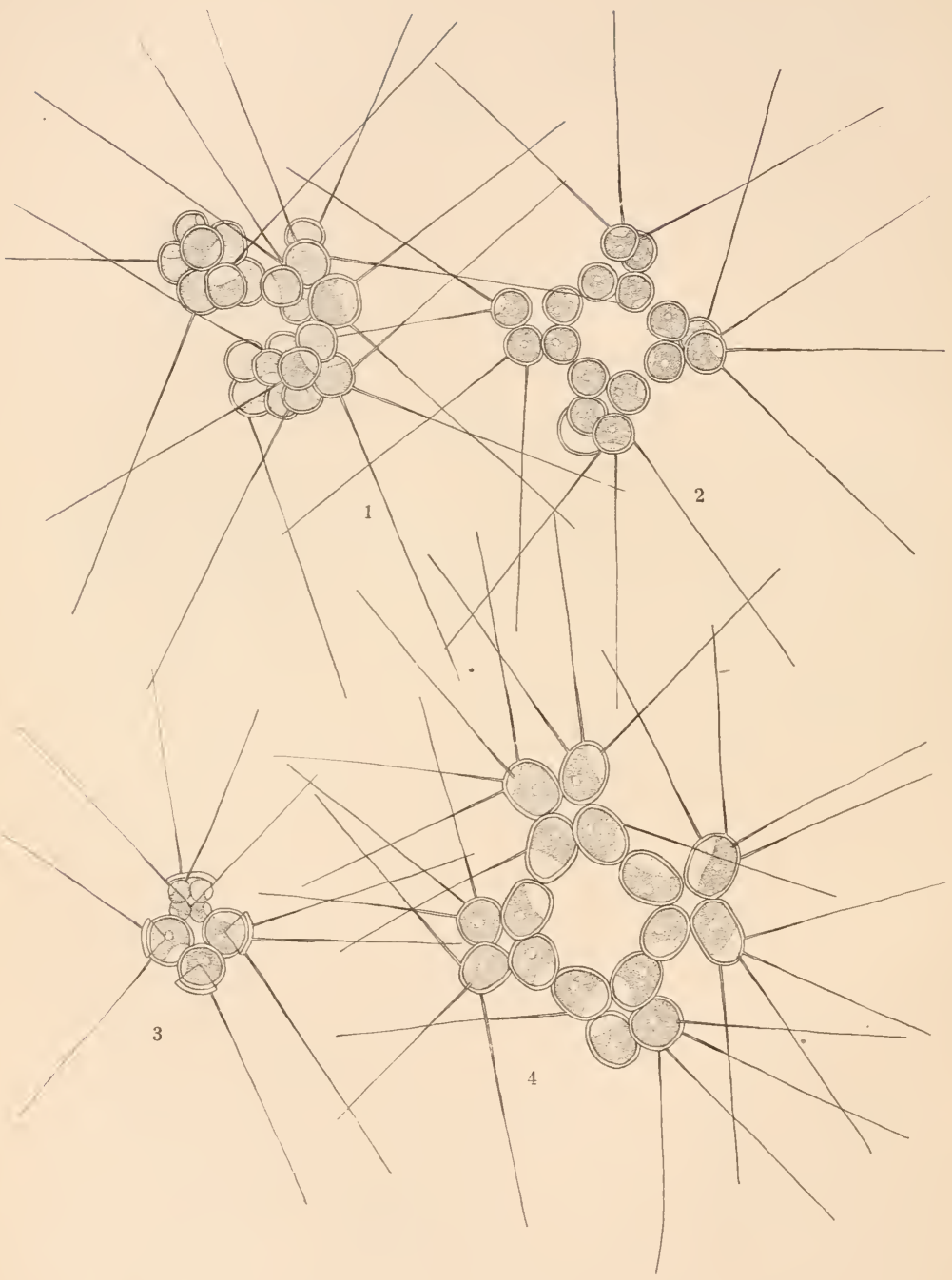


PLATE 28.

Figs. 1-3. Micractinium pusillum (x 1000).................. $\begin{array}{r}\text { Page } \\ 125\end{array}$

Fig. 4. Micractinium quadrisetum (x 1000)................ 126 
PLATE 29.

Page

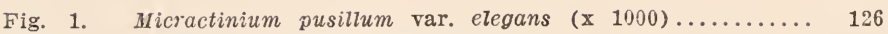

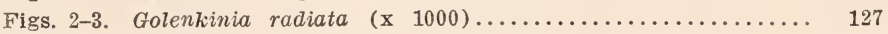

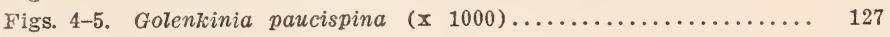

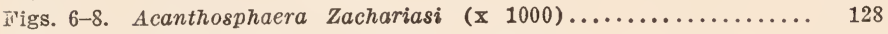

Figs. 9-11. Echinosphaerella limnetica (x 1000)................ 128 


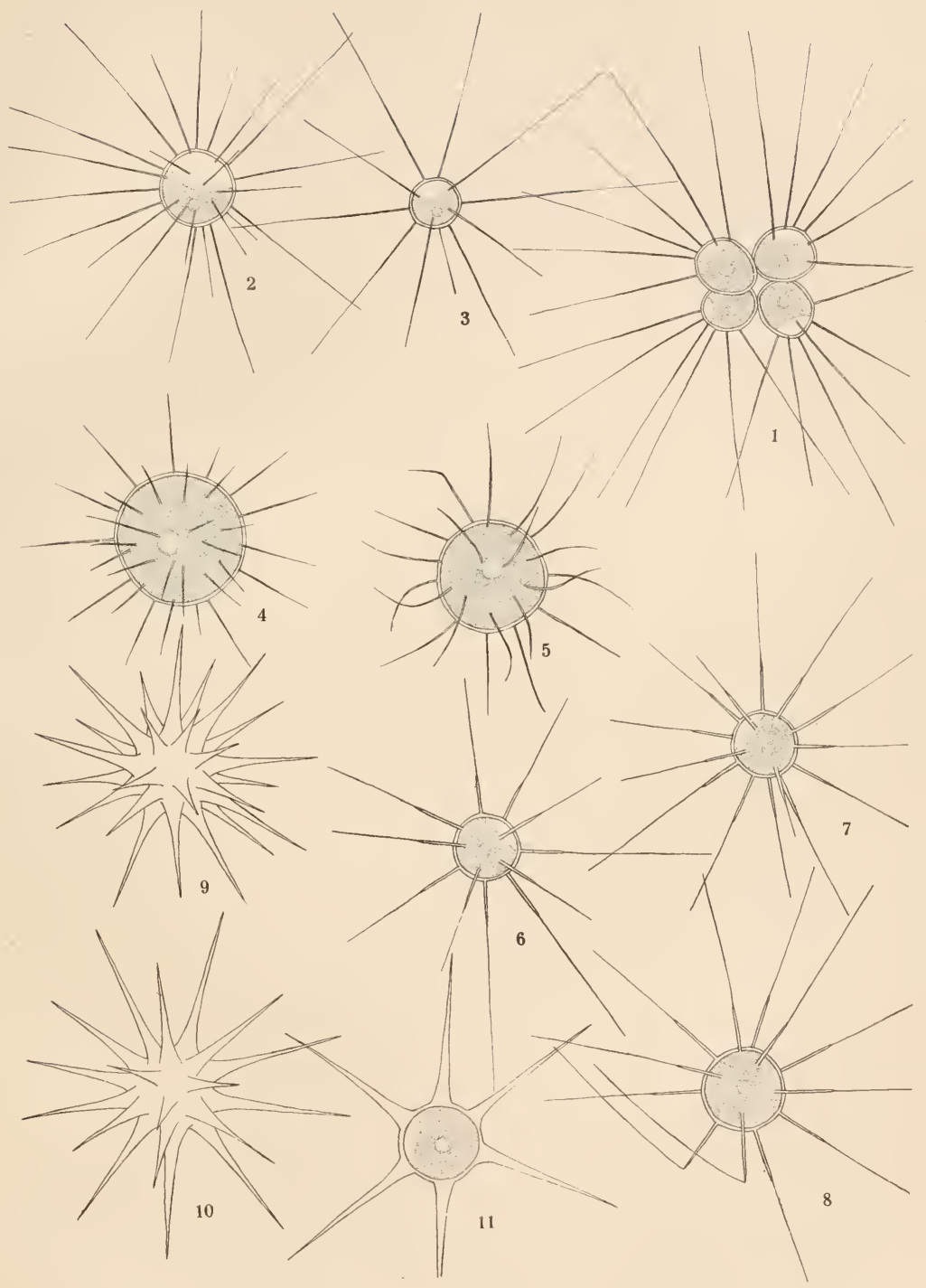




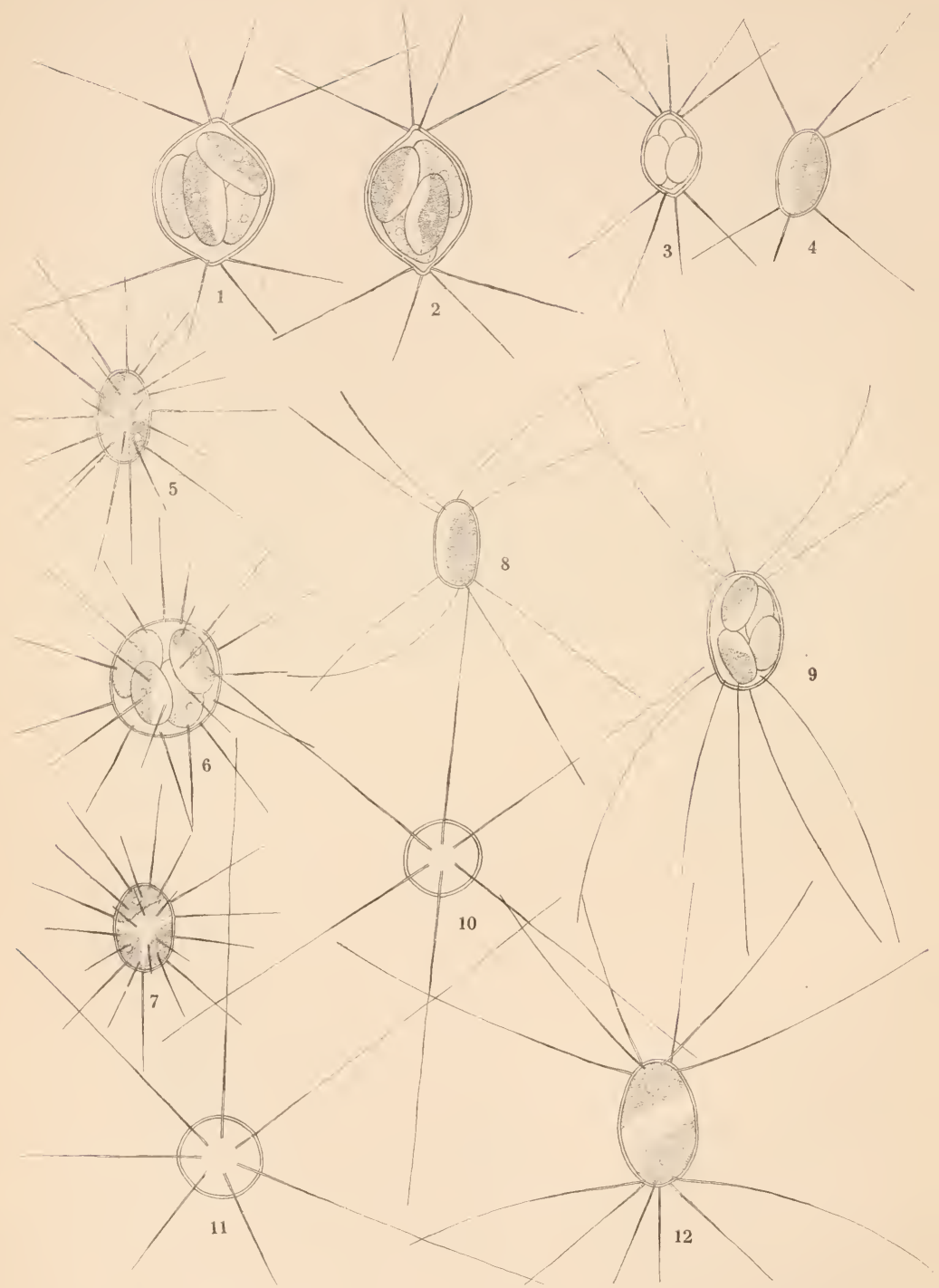


PLATE 30.

Page

Figs. 1-2. Lagerheimia citriformis $(x \quad 1000) \ldots \ldots \ldots \ldots \ldots \ldots \ldots . \ldots \ldots$

Figs. $3-4 . \quad$ Lagerheimia subsala (x 1000)................... 130

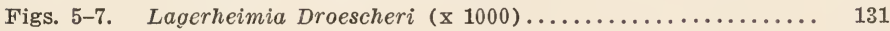

Figs. 8-9. Lagerheimia longiseta (x 1000).................. 130

Figs. 10-12. Lagerheimia longiseta var. major $(x$ 1000).......... 130 


\section{PLATE 31.}

Page

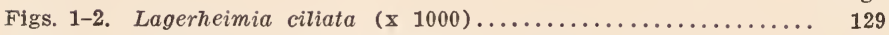

Fig. 3. Lagerheimia ciliata var. minor $(x 1000) \ldots \ldots \ldots \ldots \ldots \ldots . \ldots \ldots$

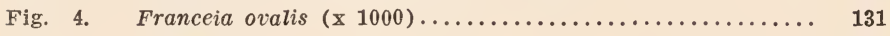

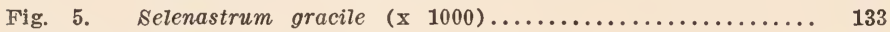

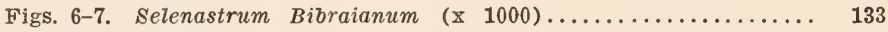

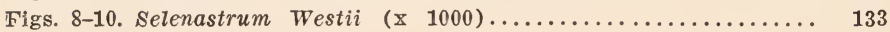




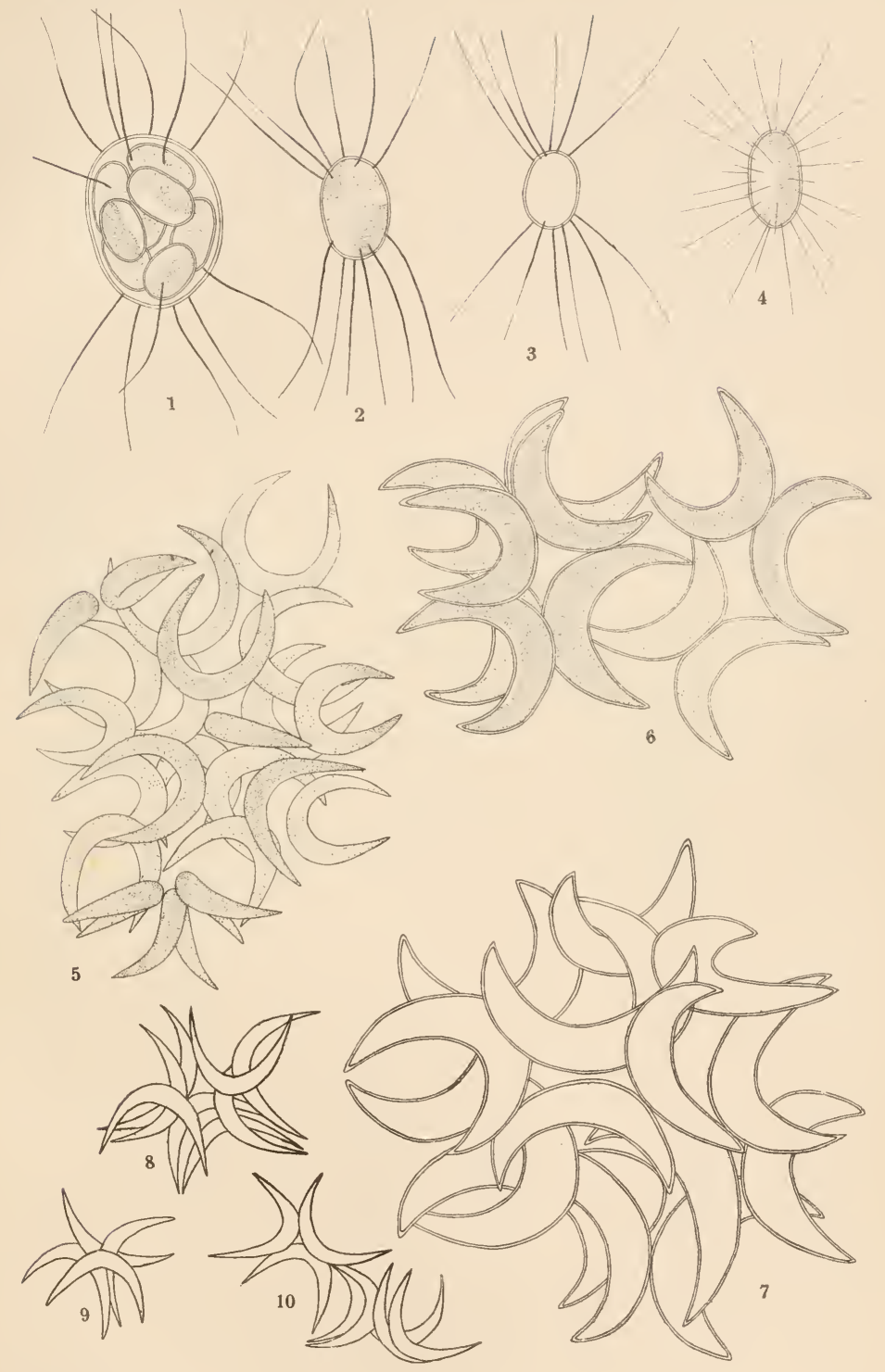


WISCONSIN SURVEY

BULLETIN 57, PLATE 32
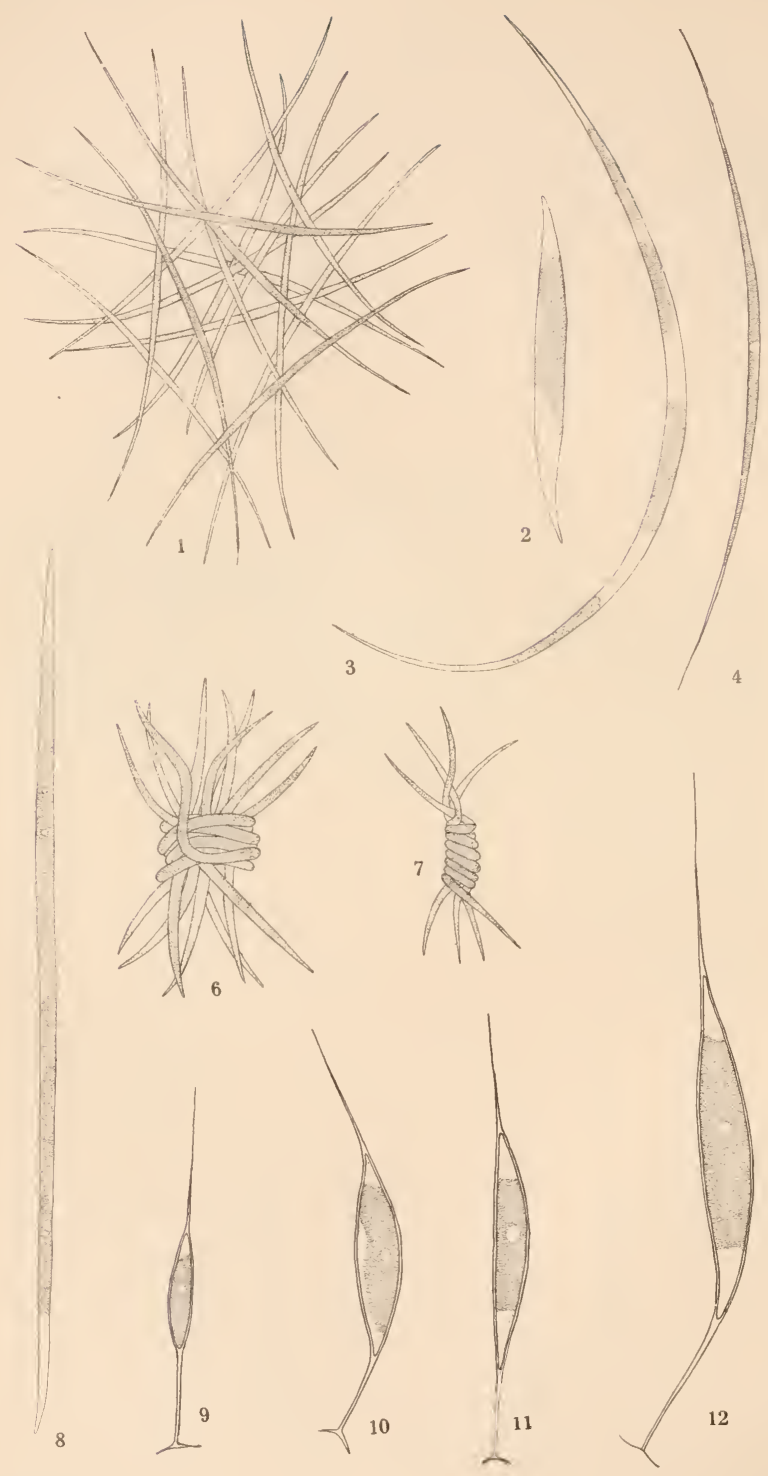
PLATE 32.

Fig. 1. Ankistrodesmus falcatus (x 1000)........... Page

Fig. 2. Ankistrodesmus falcatus var. tumidus $(\mathrm{x} 1000) \ldots \ldots . . .135$

Figs. 3-5. Ankistrodesmus falcatus var. mirabilis $(x 1000) \ldots \ldots \ldots .135$

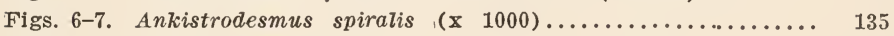

Fig. 8. Closteriopsis longissima var. tropica $(x \quad 400) \ldots \ldots \ldots \ldots . .136$

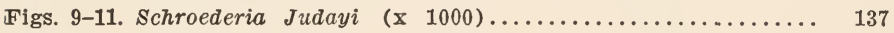

Fig. 12. Schroederia setigera $(\mathrm{x} 1000) \ldots \ldots \ldots \ldots \ldots \ldots \ldots \ldots \ldots \ldots \ldots \ldots \ldots \ldots$ 


\section{PLATE 33.}

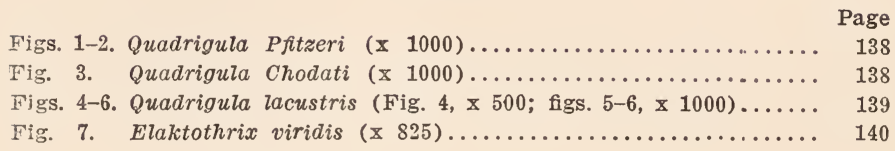



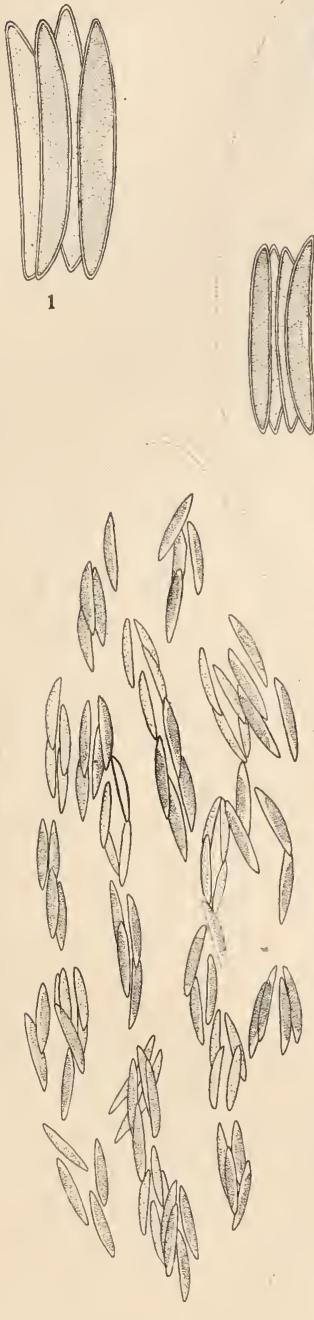

4
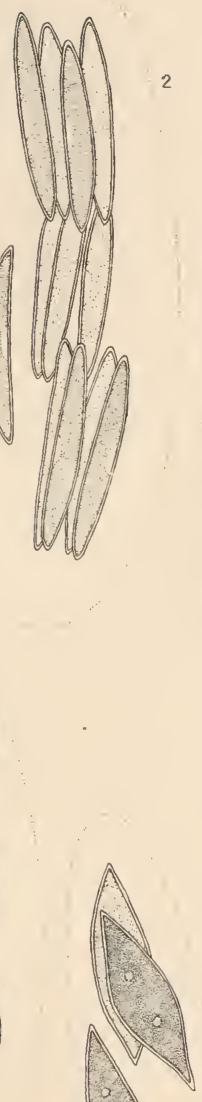

7
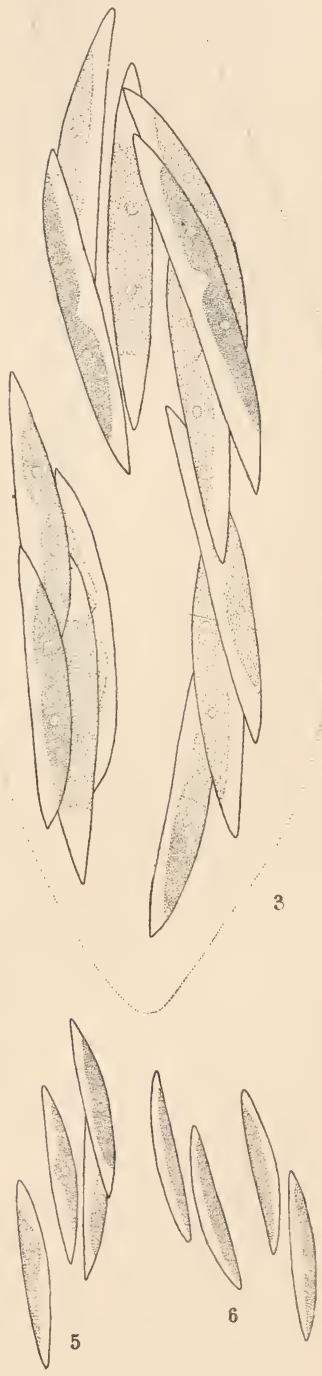

SMITH-ALGAE 
,

目

1

1

8

3

4

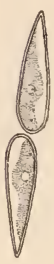

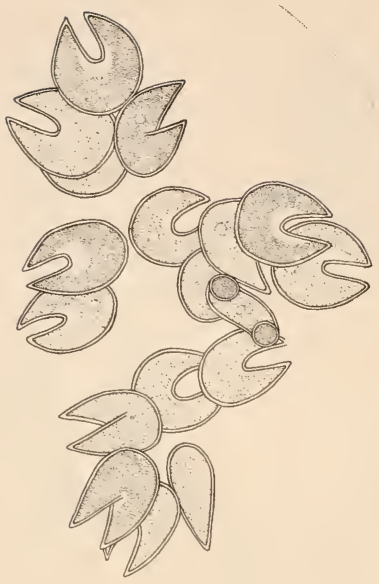
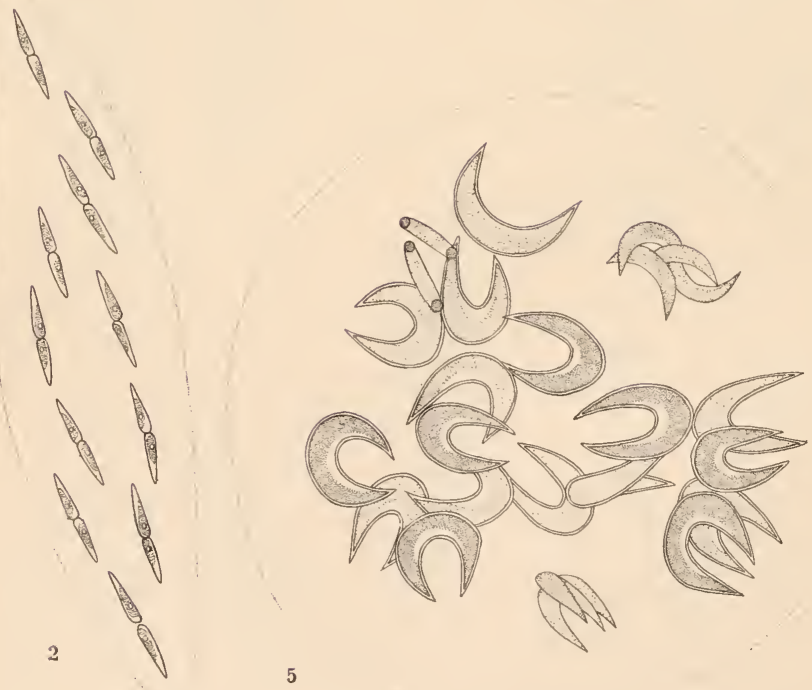
PLATE 34.

Figs. 1-3. Elaktothrix gelatinosa (Figs. 1-2, x 500; fig. 3, x 1000) ... 139

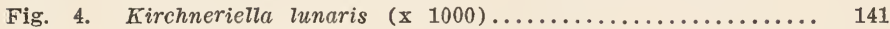

Fig. 5. Kirchneriella lunaris var. dianae $(\mathrm{x} 100 \ldots \ldots \ldots \ldots \ldots \ldots \ldots . .141$ 


\section{PLATE 35.}

Fig. 1. Kirchneriella lunaris var. irregularis $(\mathrm{x} 1000) \ldots \ldots \ldots \ldots . .62$

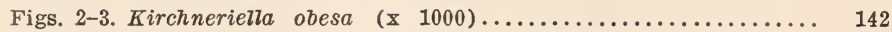

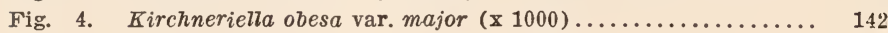

Figs. 5-6. Kirchneriella obesa var. aperta (x 1000).............. 143

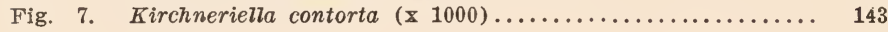



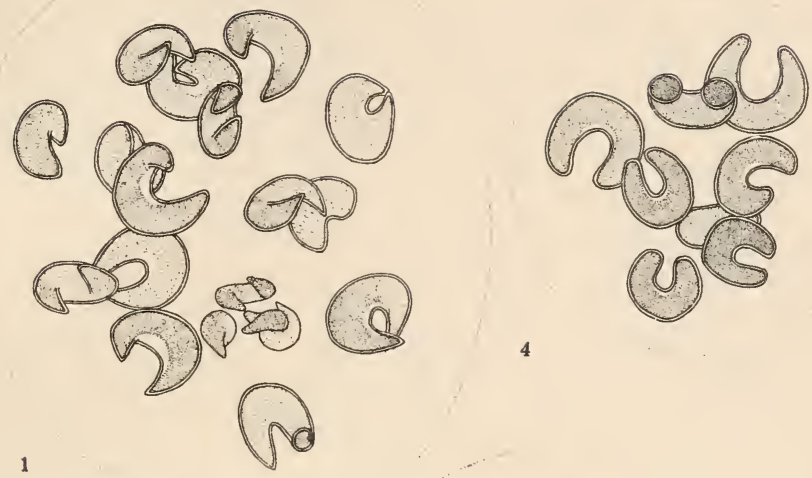

4
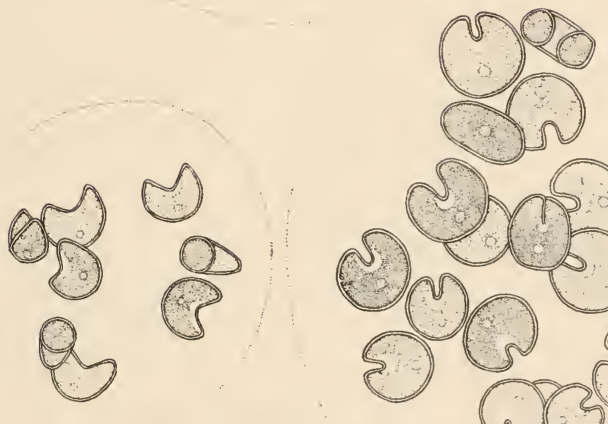

5
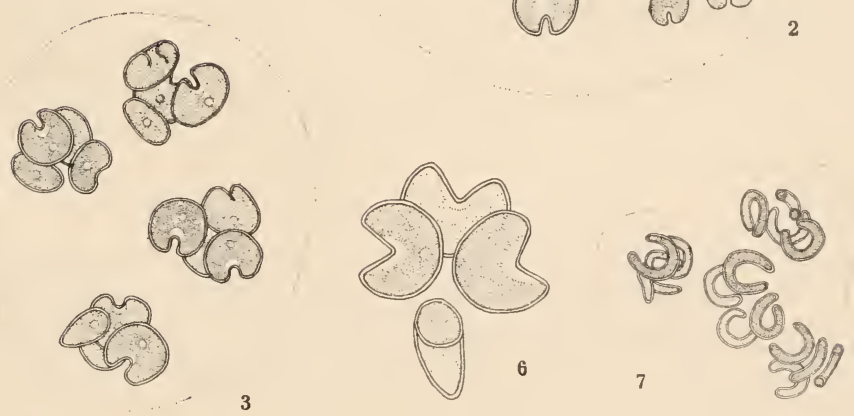

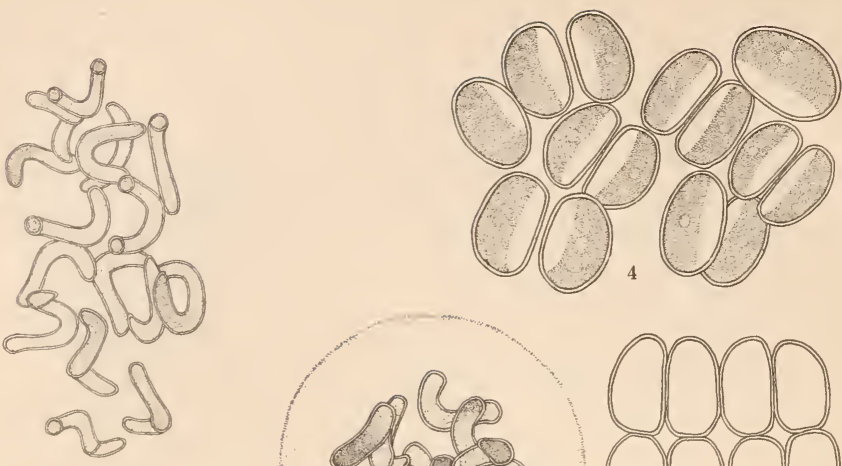

1
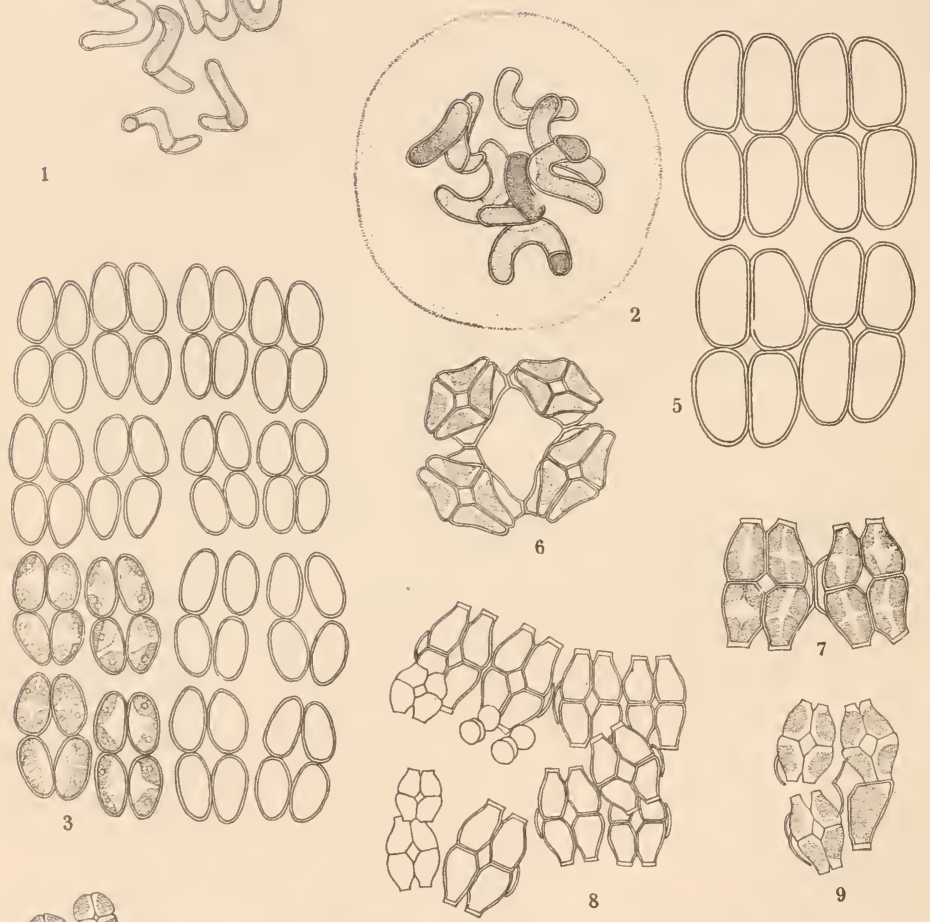

13

(1.)

201

(2)

10

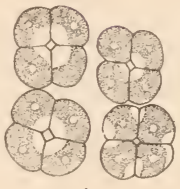

11

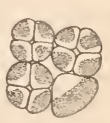

12

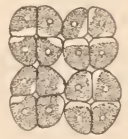

13

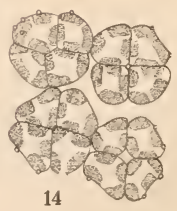


PLATE 36.

Page

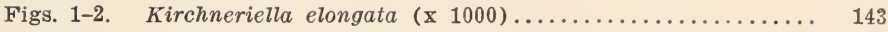

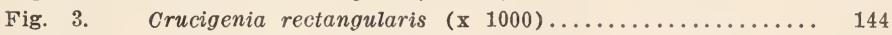

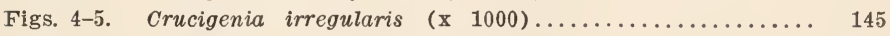

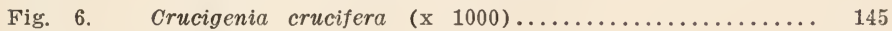

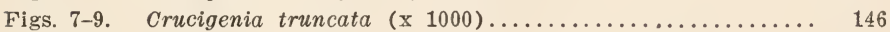

Figs. 10-14. Crucigenia quadrata $(\mathrm{x} 1000) \ldots \ldots \ldots \ldots \ldots \ldots \ldots \ldots \ldots \ldots \ldots \ldots \ldots$ 
PLATE 37.

Pig. 1. Page

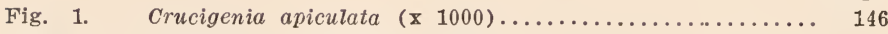

Fig. 2. Crucigcnia tetrapedia (x 1000)..................... 147

Fig. 3. Crucigenia fenstrata (x 1000)...................... 148

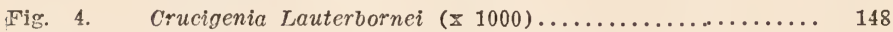

Figs. 5-6. Tetrastrum staurogeniaeforme $(x$ 1000).............. 149

Figs. 7-11. Tetradesmus wisconsinensis $(x \quad 1000) \ldots \ldots \ldots \ldots \ldots \ldots \ldots \ldots$

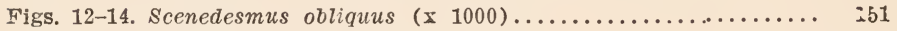

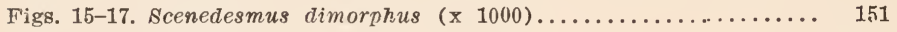

Figs. 18-20. scenedesmus bijuga (x 1000).................. 152 

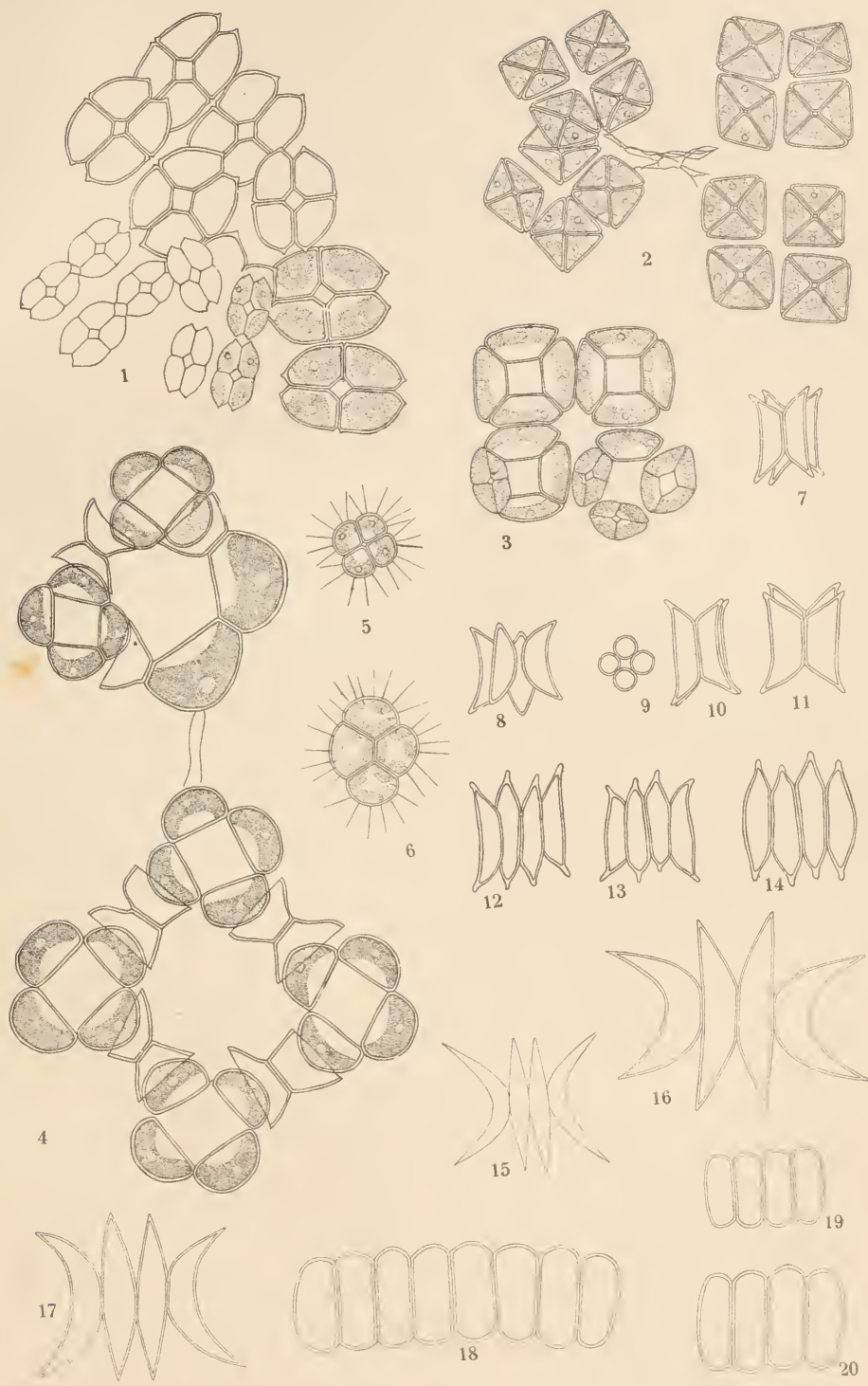

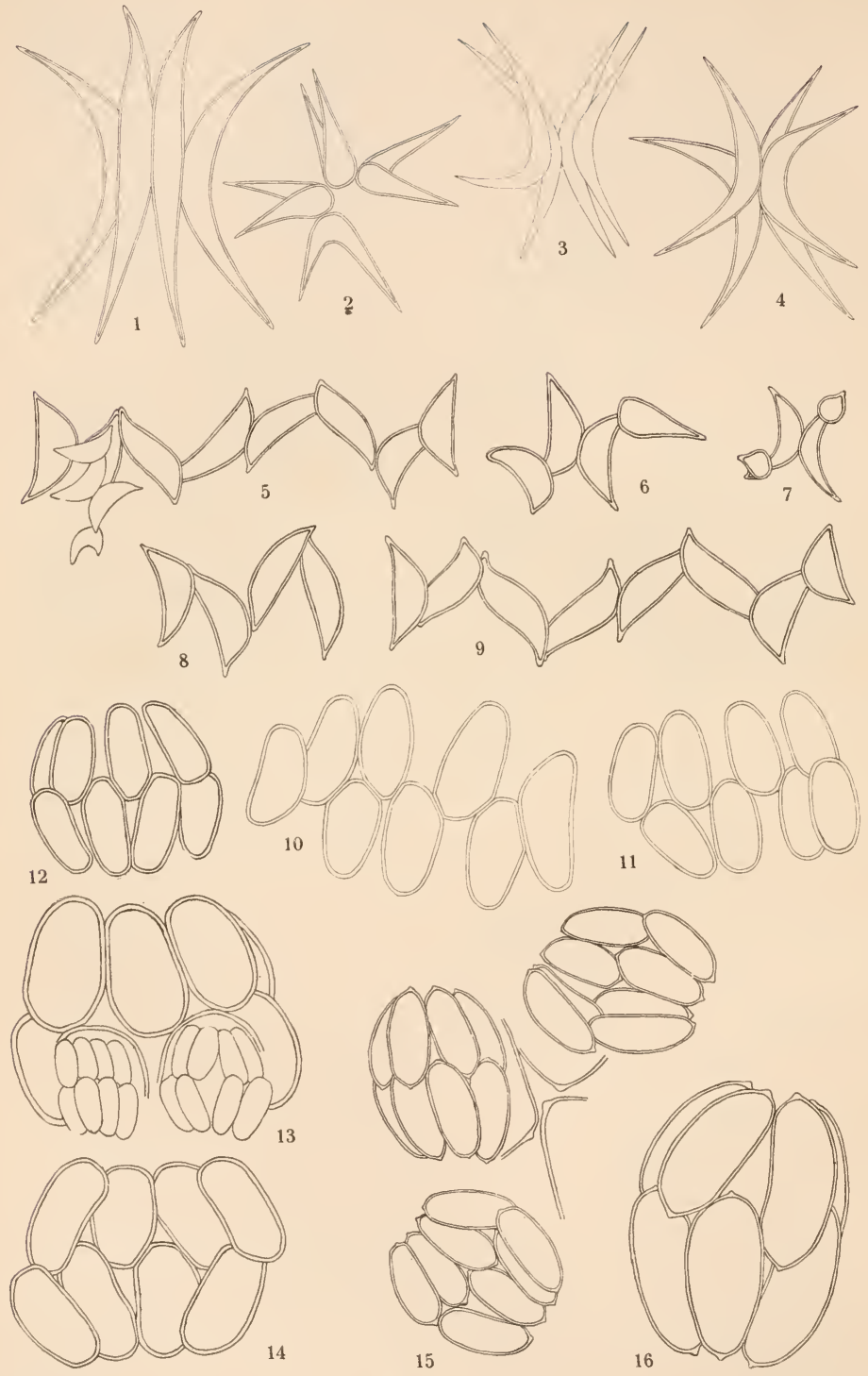

14

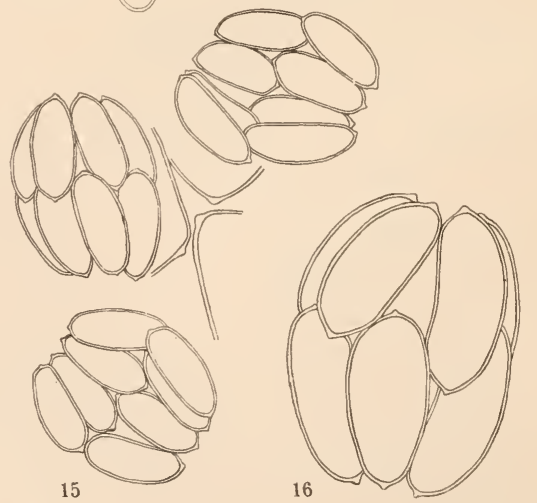


PLATE 38.

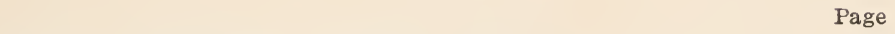

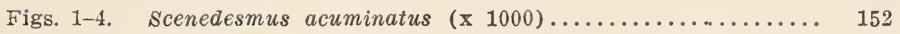

Figs. 5-9. Scenedesmus Bernardii (x 1000)................. 152

F'igs. 10-11. Scenedesmus bijuga var. alternans $(x$ 1000)........... 153

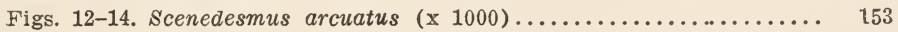

Figs. 15-16. Scenedesmus arcuatus var. capitatus $(x$ 1000)....... 153 


\section{PLATE 39.}

Tig. 1-3. Sage

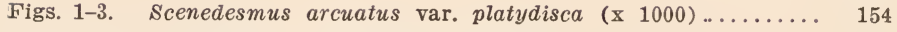

Figs. 4-6. Scenedesmus acutiformis $(x 1000) \ldots \ldots \ldots \ldots \ldots \ldots \ldots . \ldots \ldots$

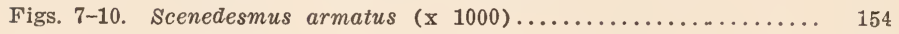

Fig. 11. Scenedesmus armatus var. major $(\mathrm{x} 1000) \ldots \ldots \ldots \ldots \ldots . \ldots . \ldots$

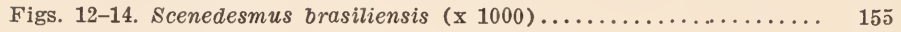

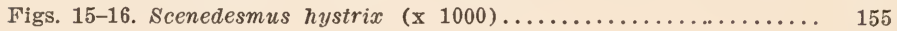

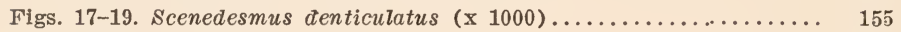

Figs. 20-22. Scenedesmus longus $(x \quad 1000) \ldots \ldots \ldots \ldots \ldots \ldots \ldots \ldots . \ldots \ldots$

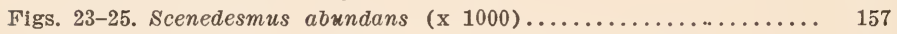

Figs. 26-27. Scenedesmus abundans var. longicauda $(\mathrm{x} 1000) \ldots \ldots \ldots .157$ 

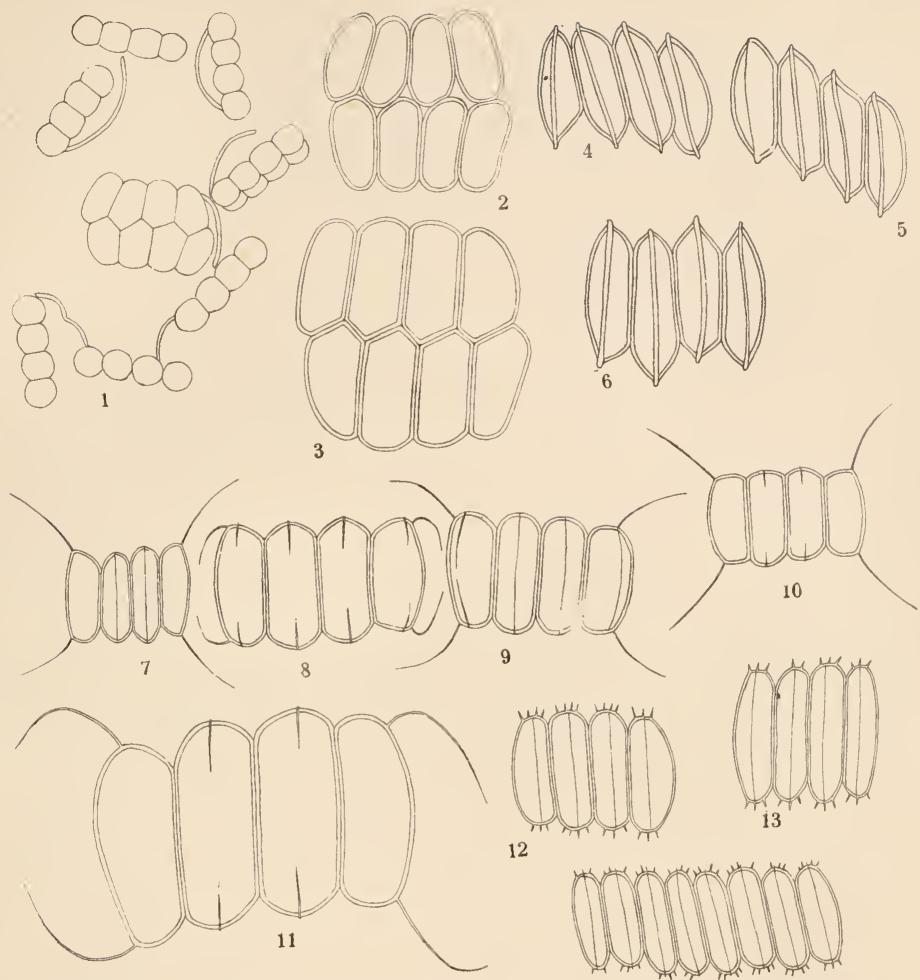

12
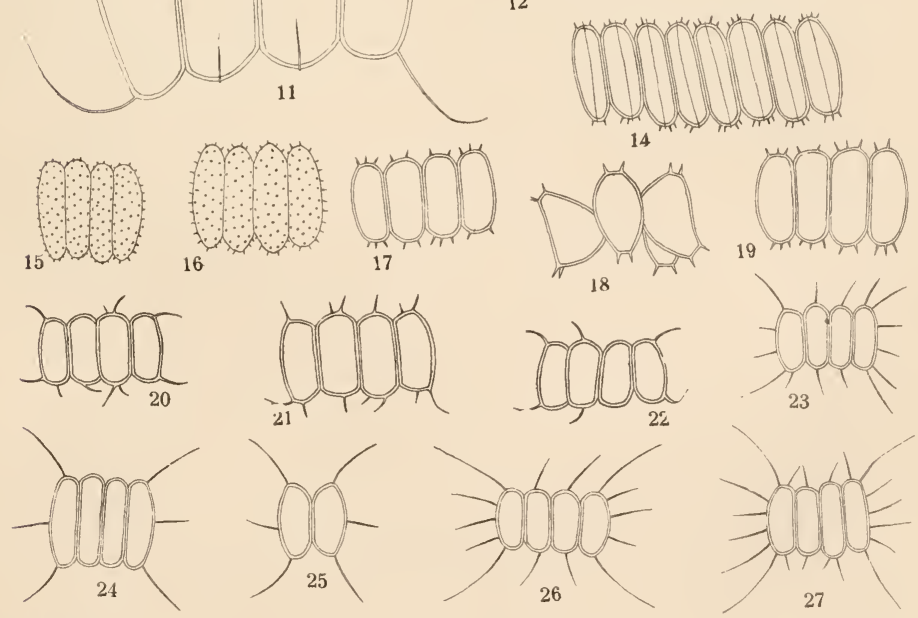


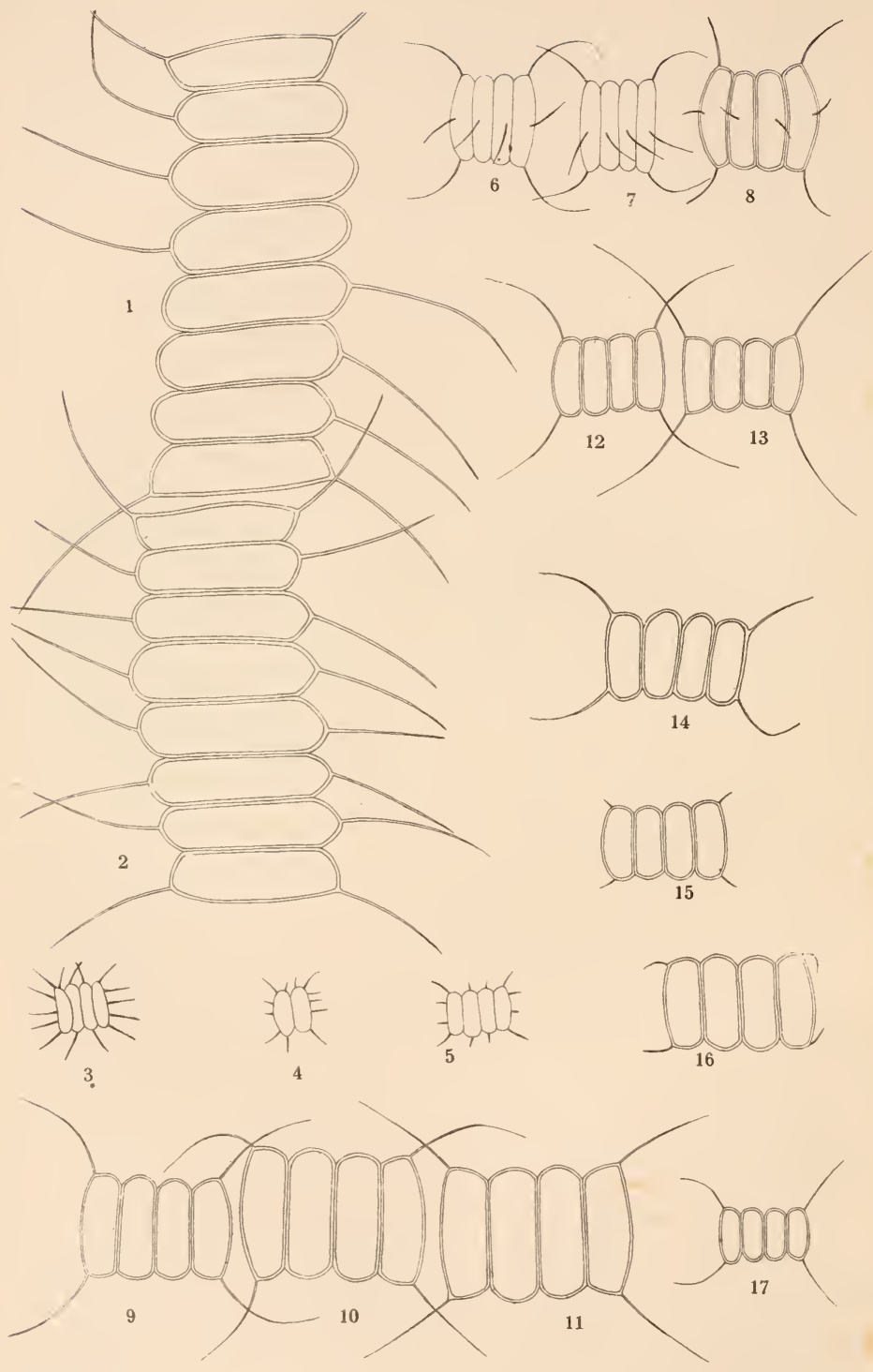


PLATE 40.

Page

Figs. 1-2. Scenedesmus longus var. Naegelii $(\mathrm{x} 1000) \ldots \ldots \ldots \ldots .156$

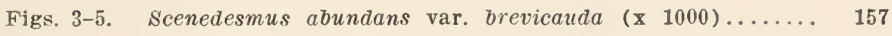

Figs. 6-8. Scenedesmus abundans var. asymmetrica (x 1000)..... 157

Figs. 9-11. Scenedesmus quadricauda (x 1000).................. 158

Figs. 12-14. Scenedesmus quadricauda var. longispina (x 1000)..... 159

Figs. 15-16. Scenedesmus quadricauda var. quadrispina $(x \quad 1000) \ldots . \quad 158$

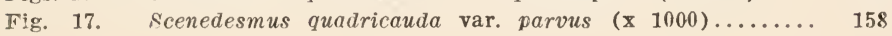


PLATE 41.

Page

Figs. 1-2. Scenedesmus quadricauda var. maximus $(\mathrm{x} 1000) \ldots . . . \quad 159$

Figs. 3-7. Scenedesmus quadricauda var. Westii (x 1000)........ 159

Figs. 8-11. Scenedesmus opoliensis $\left(\begin{array}{l}x \\ 1000\end{array}\right) \ldots \ldots \ldots \ldots \ldots \ldots \ldots \ldots \ldots$

Figs. 12-13. Coelastrum microporum (x 825$) \ldots \ldots \ldots \ldots \ldots \ldots \ldots . . \ldots$ 

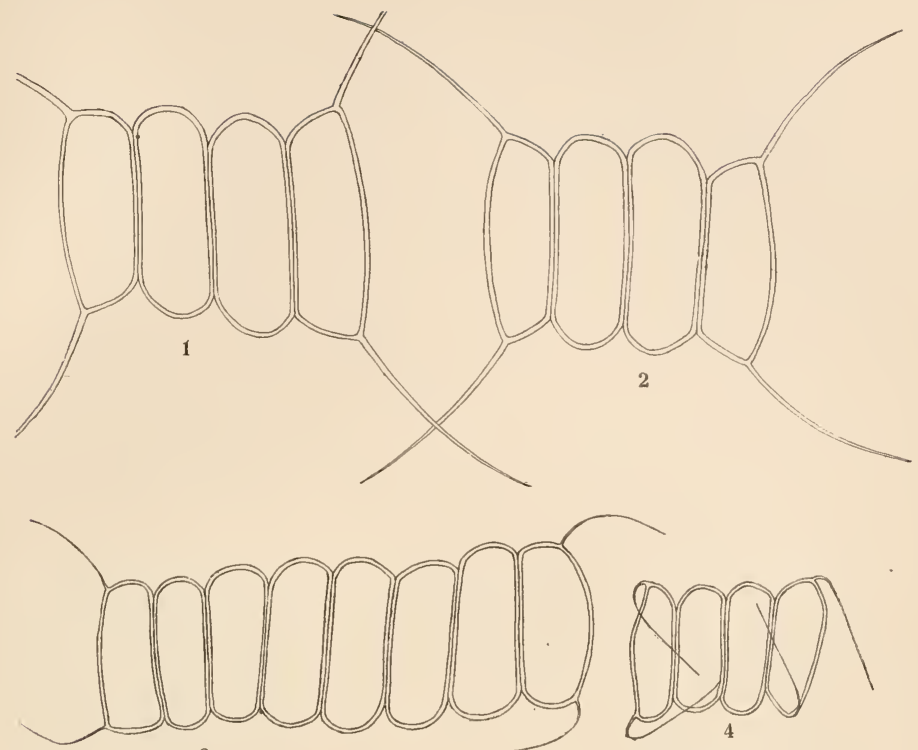

3
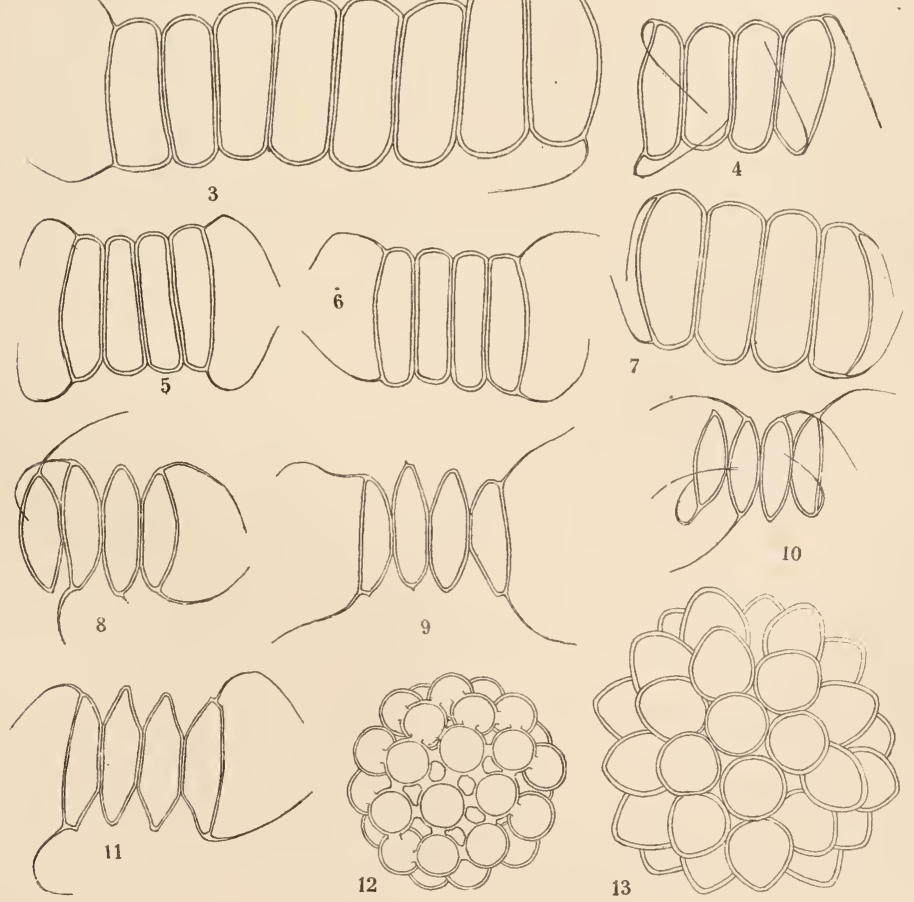

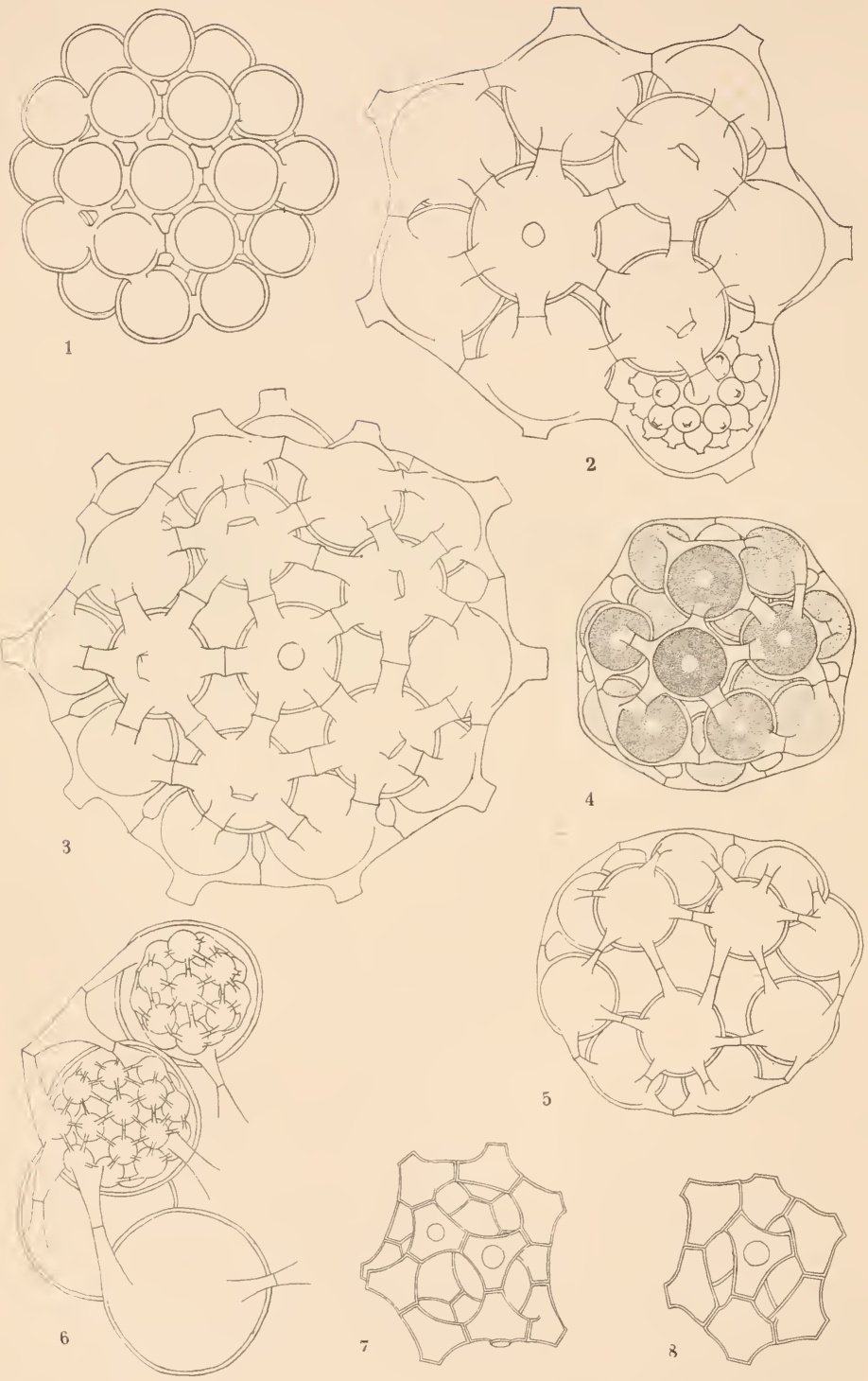
PLATE 42.

Page

Fig. 1. Coelastrum microporum $(x 825) \ldots \ldots \ldots \ldots \ldots \ldots \ldots \ldots \ldots . \ldots \ldots$

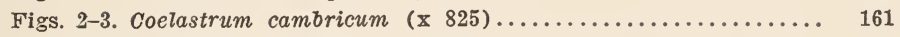

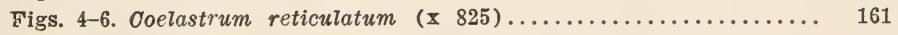

Figs. 7-8. Coelastrum proboscideum (x 825)..................... 162 


\section{PLATE 43.}

Page

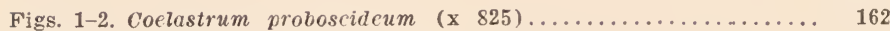

Figs. 3-5. Actinastrum gracillimum (x 1000)................ 164

Figs. 6-7. Actinastrum Hantzschi (Fig. 6, × 500; fig. 7, × 1000)...... 164

Fig. 8. Actinastrum Hantzschi var. elongatum $(\times 1000) \ldots \ldots \ldots .165$ 


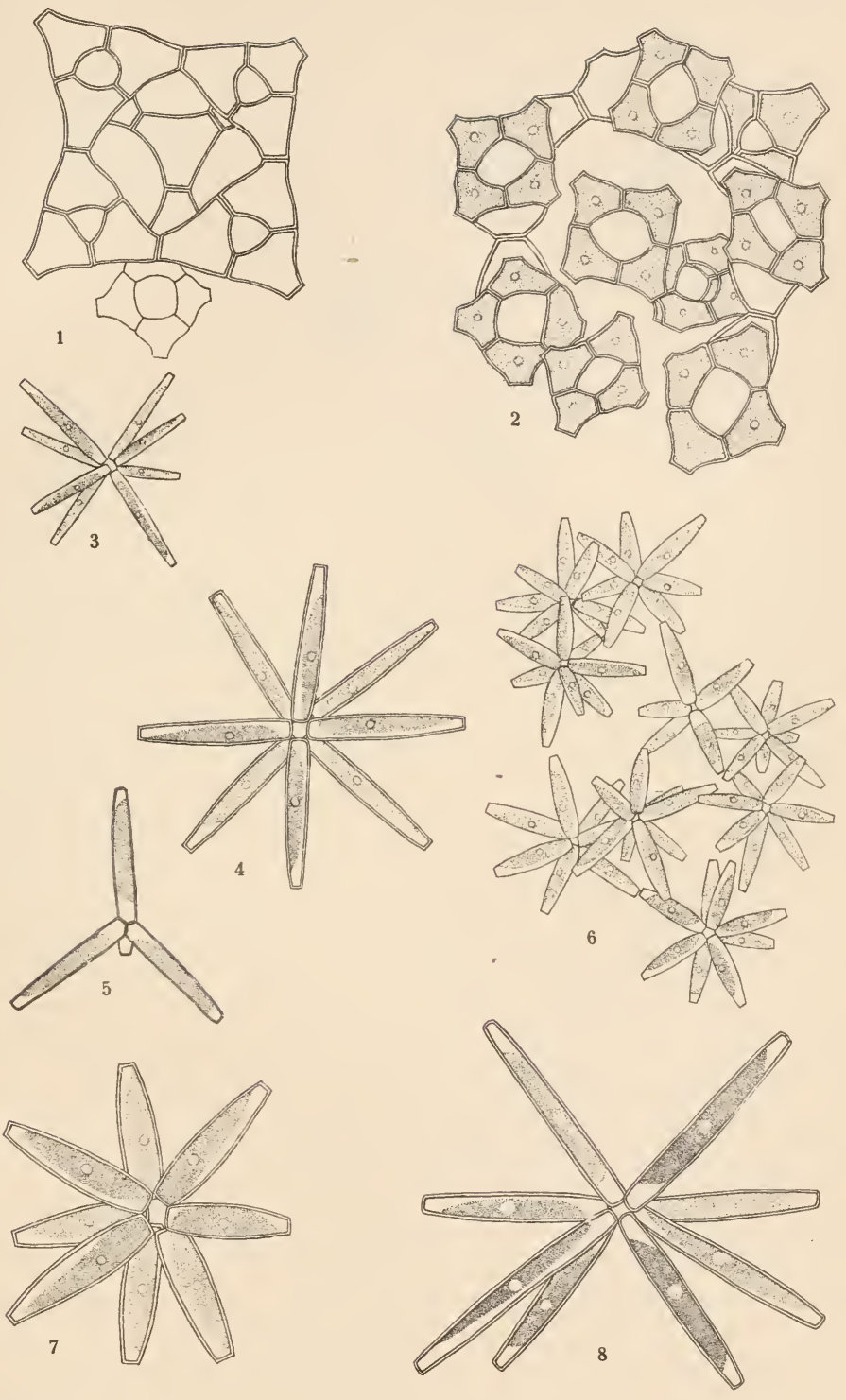




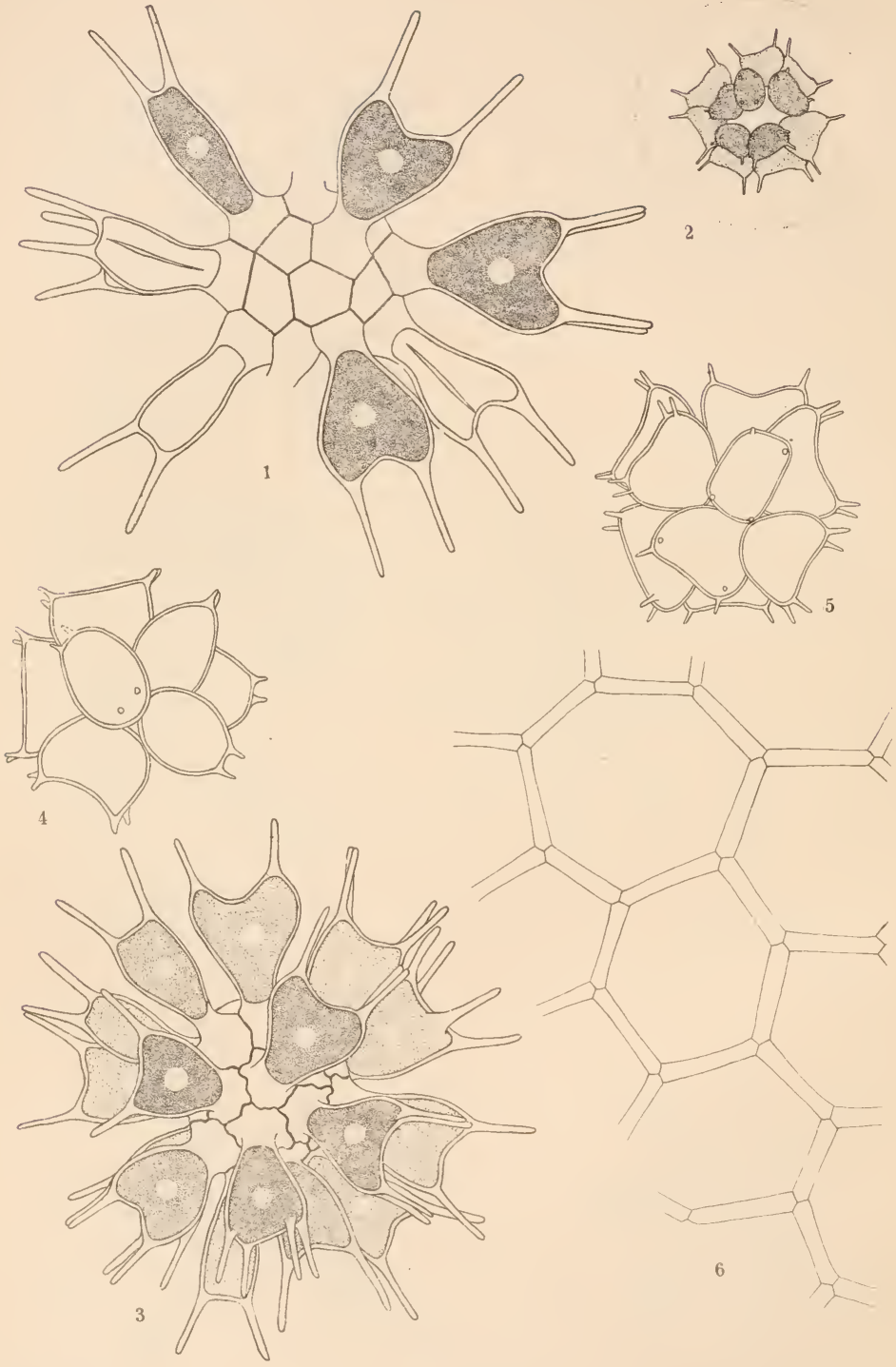


PLATE 44.

Page

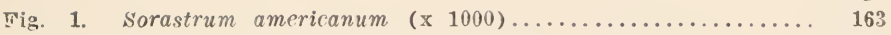

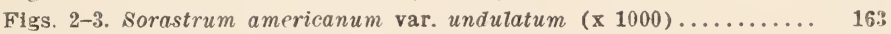

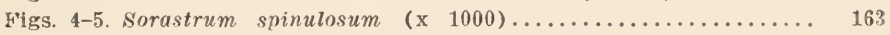

Fig. 6. Hydrodictyon reticulatum $(x \quad 100) \ldots \ldots \ldots \ldots \ldots \ldots \ldots \ldots \ldots$ 
PLATE 45.

Tig.

Fig. 1. Hydrodictyon reticulatum $(x$ 266) $\ldots \ldots \ldots \ldots \ldots \ldots \ldots \ldots, 166$

Figs. 2-6. Pediastrum simplex var. duodenarium (x 333) ........ 167

Fig. 7. Pediastrum integrum $(x \quad 333) \ldots \ldots \ldots \ldots \ldots \ldots \ldots \ldots \ldots \ldots \ldots, 168$

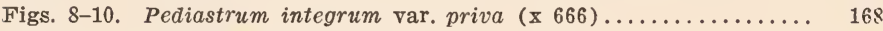

Fig. 11. Pediastrum araneosum $(x \quad 333) \ldots \ldots \ldots \ldots \ldots \ldots \ldots \ldots \ldots . \ldots \ldots$

Figs. 12-13. Pediastrum araneosum var. rugulosum (Fig $12, \mathrm{x} 333$,

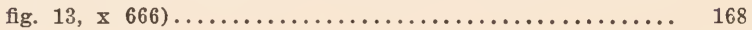



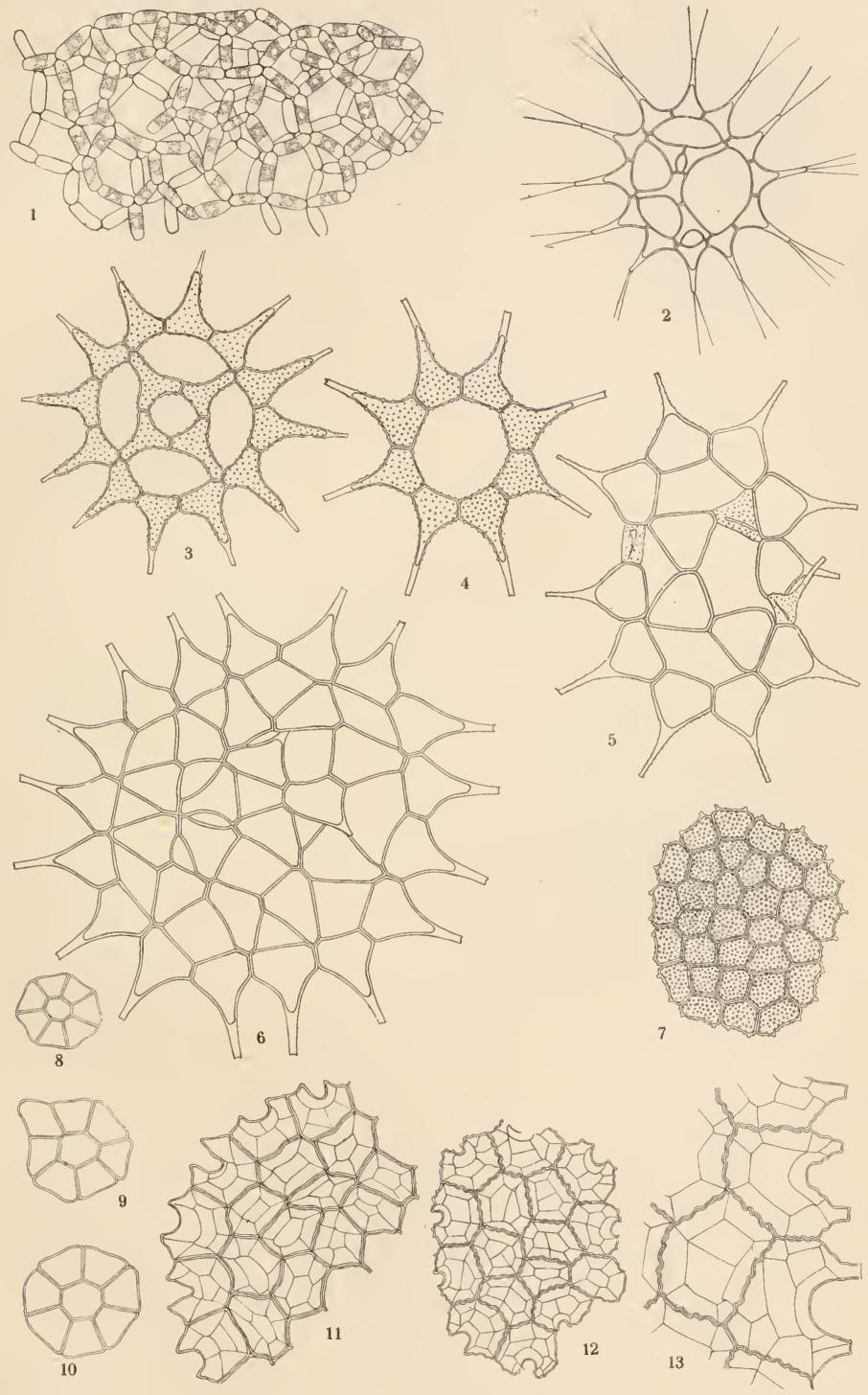

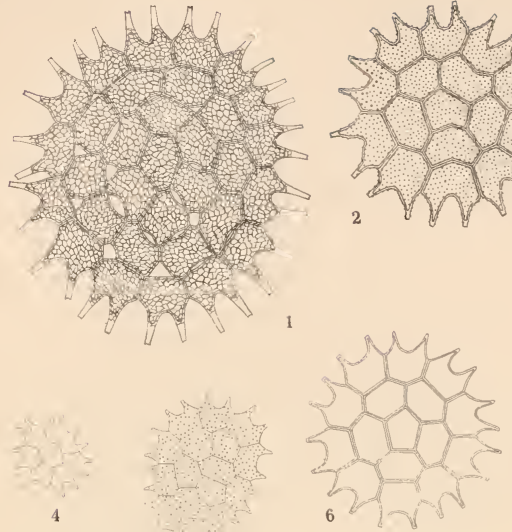

4

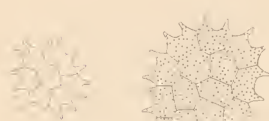

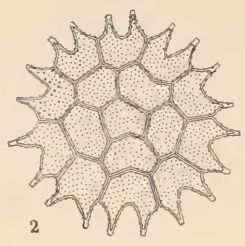

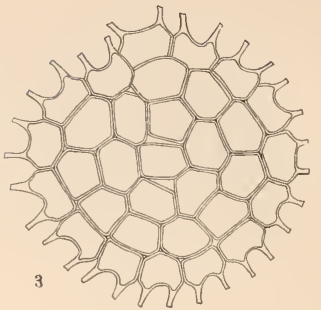

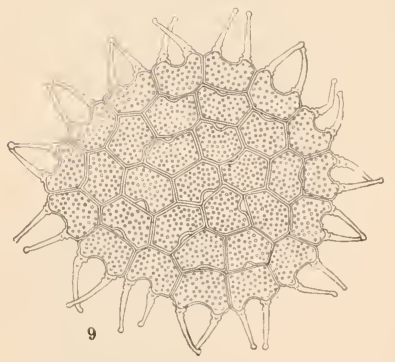
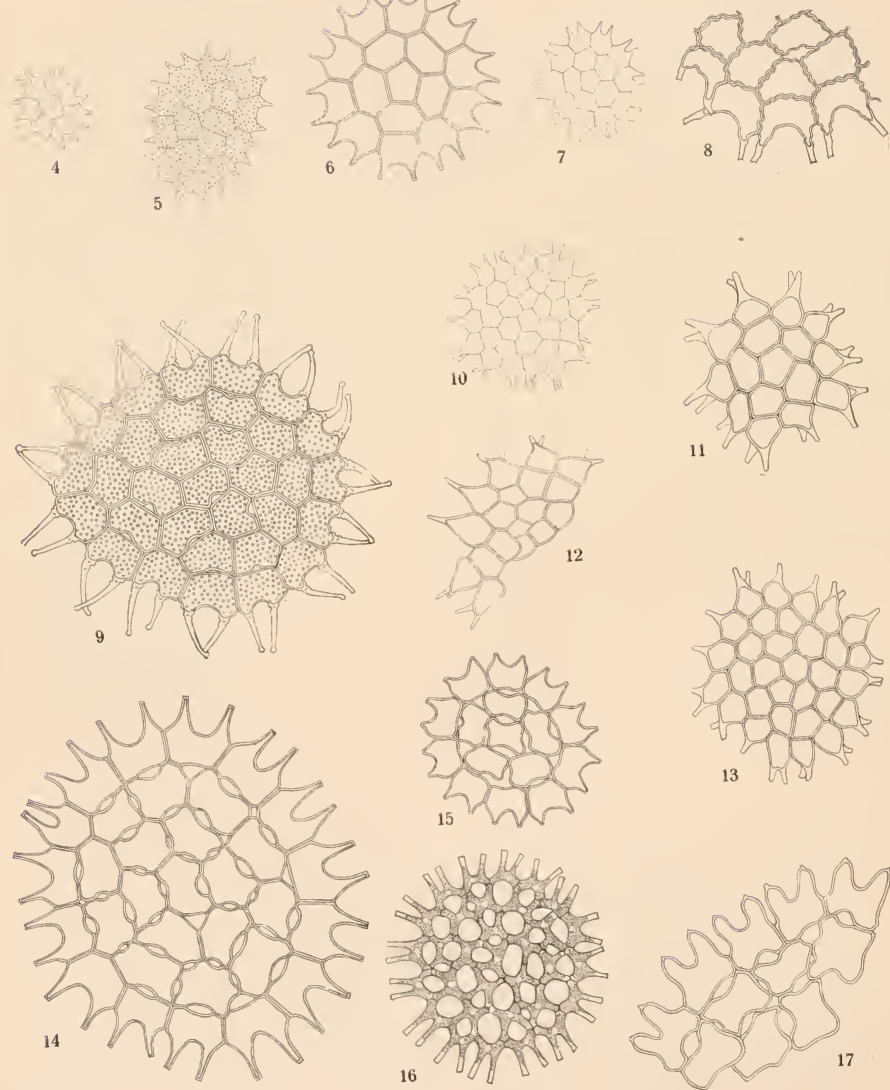

C 780
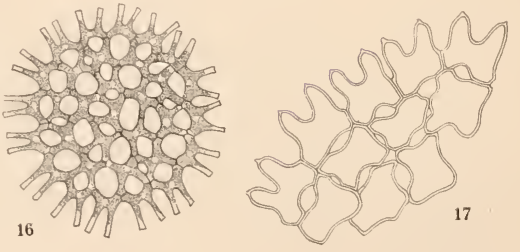
PLATE 46.

Pig. 1. Page

Fig. 1. Pediastrum sculptatum $(x 333) \ldots \ldots \ldots \ldots \ldots \ldots \ldots \ldots \ldots . \ldots \ldots$

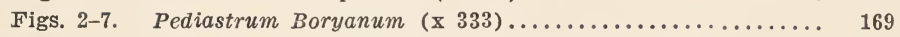

Fig. 8. Pediastrum Boryanum var. undulatum $(\mathrm{x} 333) \ldots \ldots \ldots . . . .6$

Fig. 9. Pediastrum Boryanum var. longicorne $(x 333) \ldots \ldots \ldots .170$

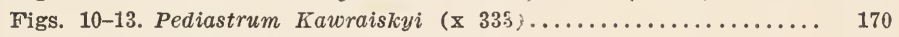

Figs. 14-16. Pediastrum duplex (x 333 )..................... 171

Fig. 17. Pediastrum duplex var. rotundatum (x 333$) \ldots \ldots \ldots \ldots . \quad 172$ 


\section{PLATE 47.}

Figs. 1-3. Pediastrum duplex var. clathratum (x 333$) \ldots \ldots \ldots \ldots \ldots \ldots$

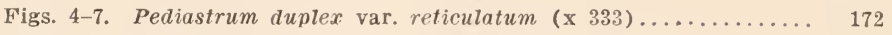

Figs. 8-11. Pediastrum duplex var. gracillimum ( х 333 ) . . . . . . 172 

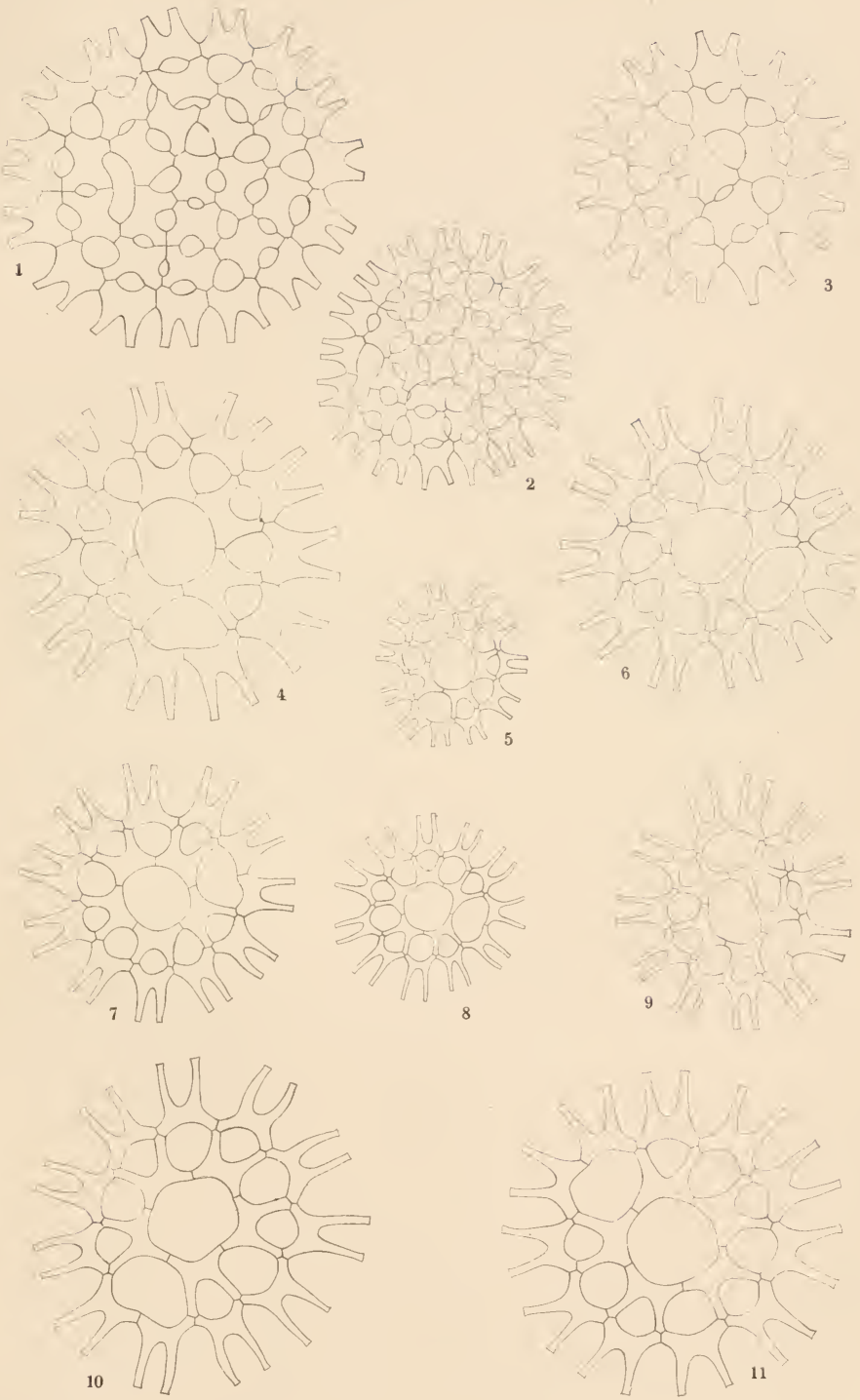


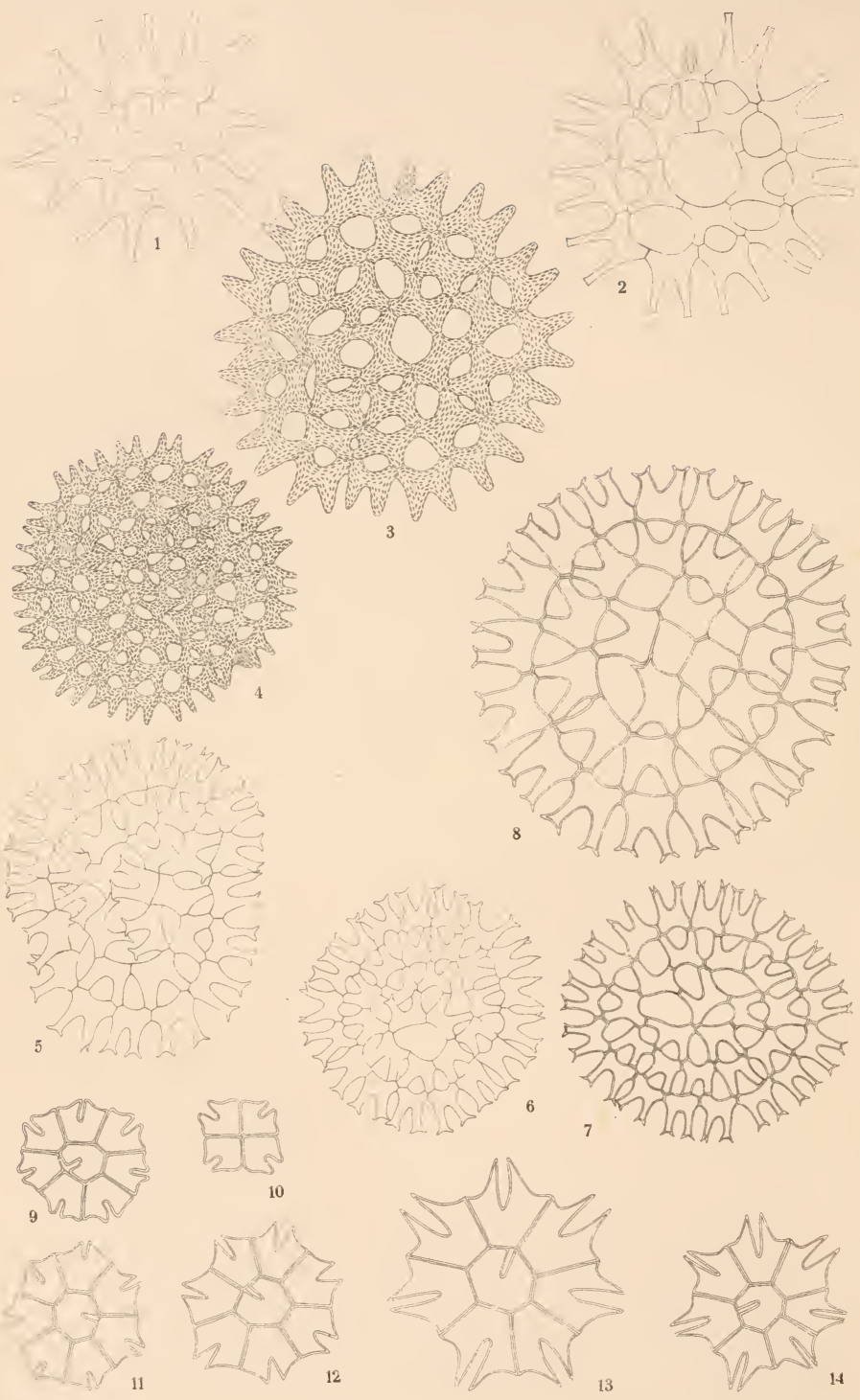




\section{PLATE 43.}

Page

Figs. 1-2. Pediastrum duplex var. gracillimum (x 333$) \ldots \ldots \ldots \ldots . . \ldots 172$

Figs. 3-4. Pediastrum duplex var. cohaerens $(x \quad 333) \ldots \ldots \ldots \ldots .173$

Figs. 5-8. Pediastrum biradiatum $(\mathrm{x} 333) \ldots \ldots \ldots \ldots \ldots \ldots \ldots \ldots . \ldots \ldots$

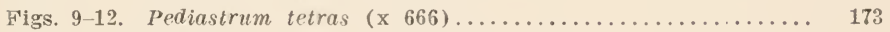

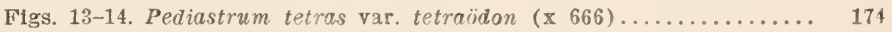


PLATE 49.

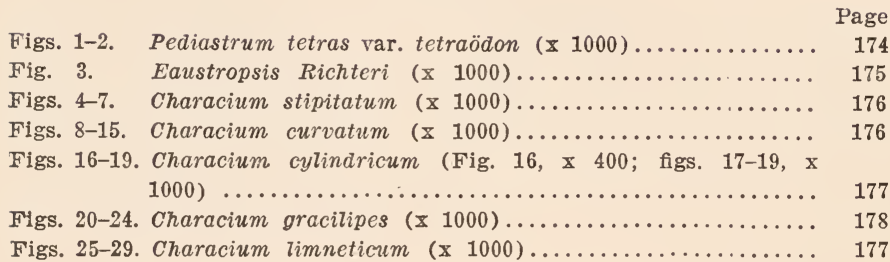



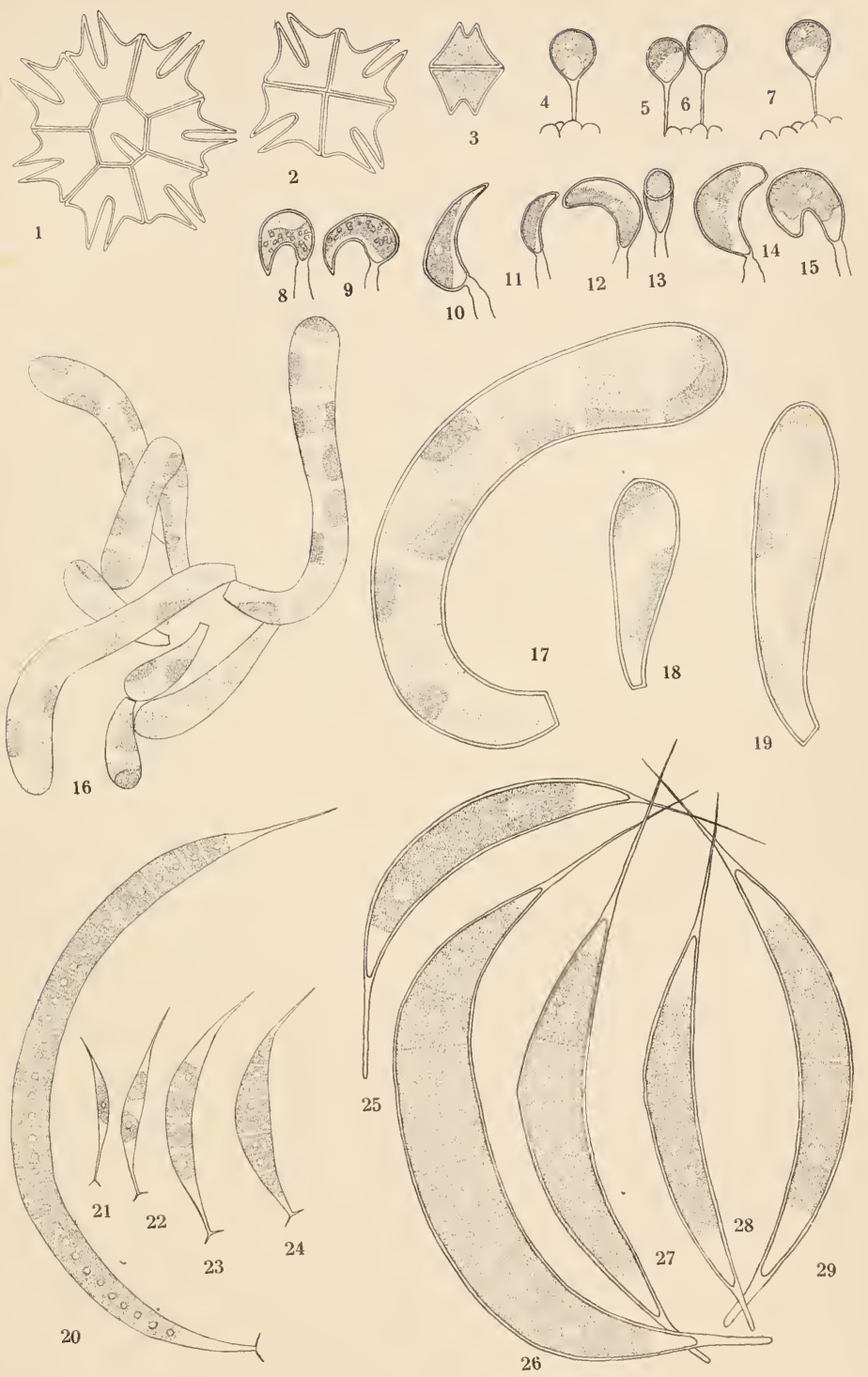

SMITH-ALGAE 

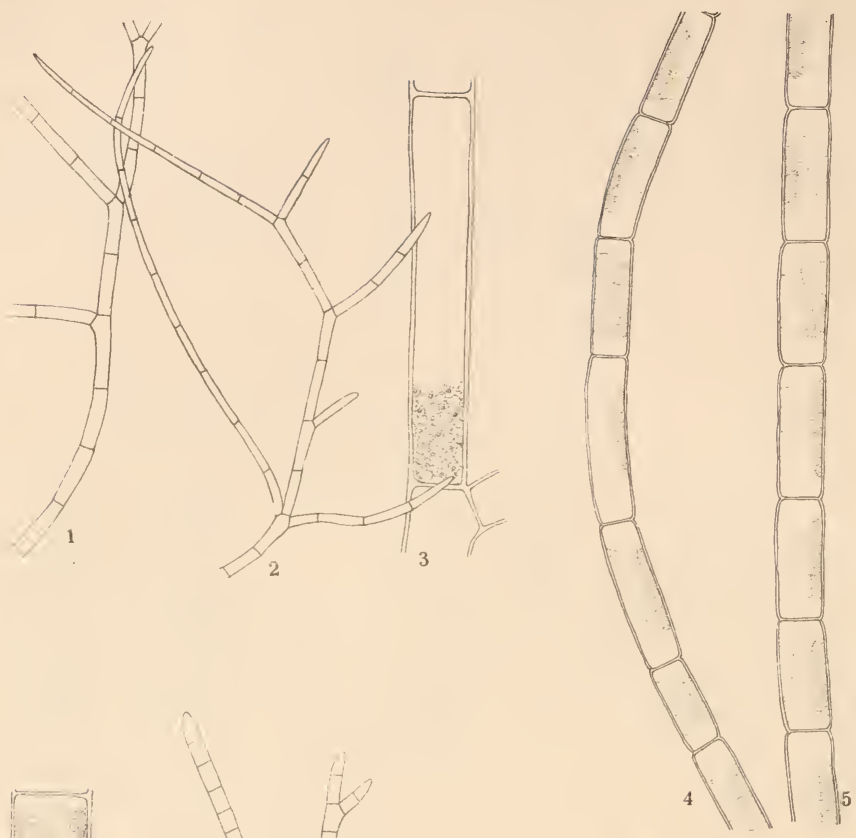

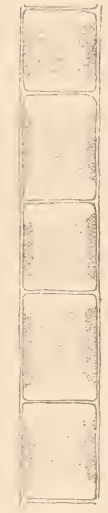

6
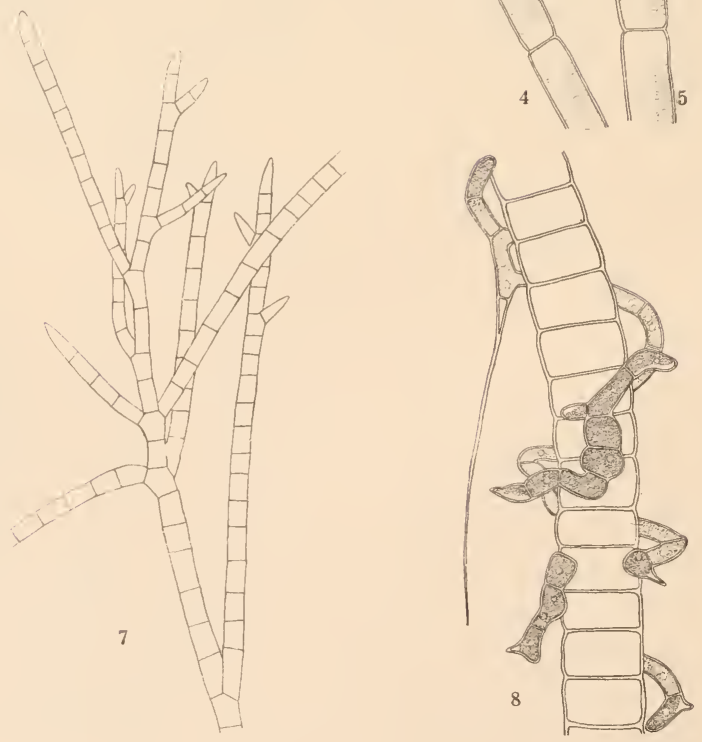
PLATE 50.

Figs. 1-3. Cladophora glomerata (Figs. 1-2, x 50, fig. 3, x 300 )..... 182

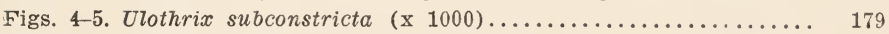

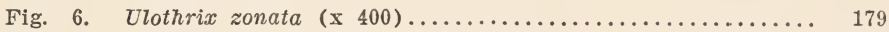

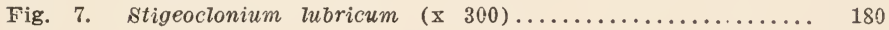

Fig. 8. Aphanochaete vermicutoides (x 400)................. 181 
PLATE 51.

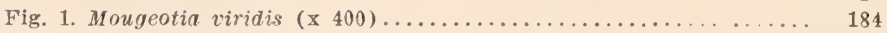

Fig. 2. Zygnema pectinatum (x 400) ........................ 185

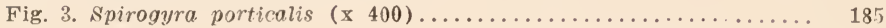




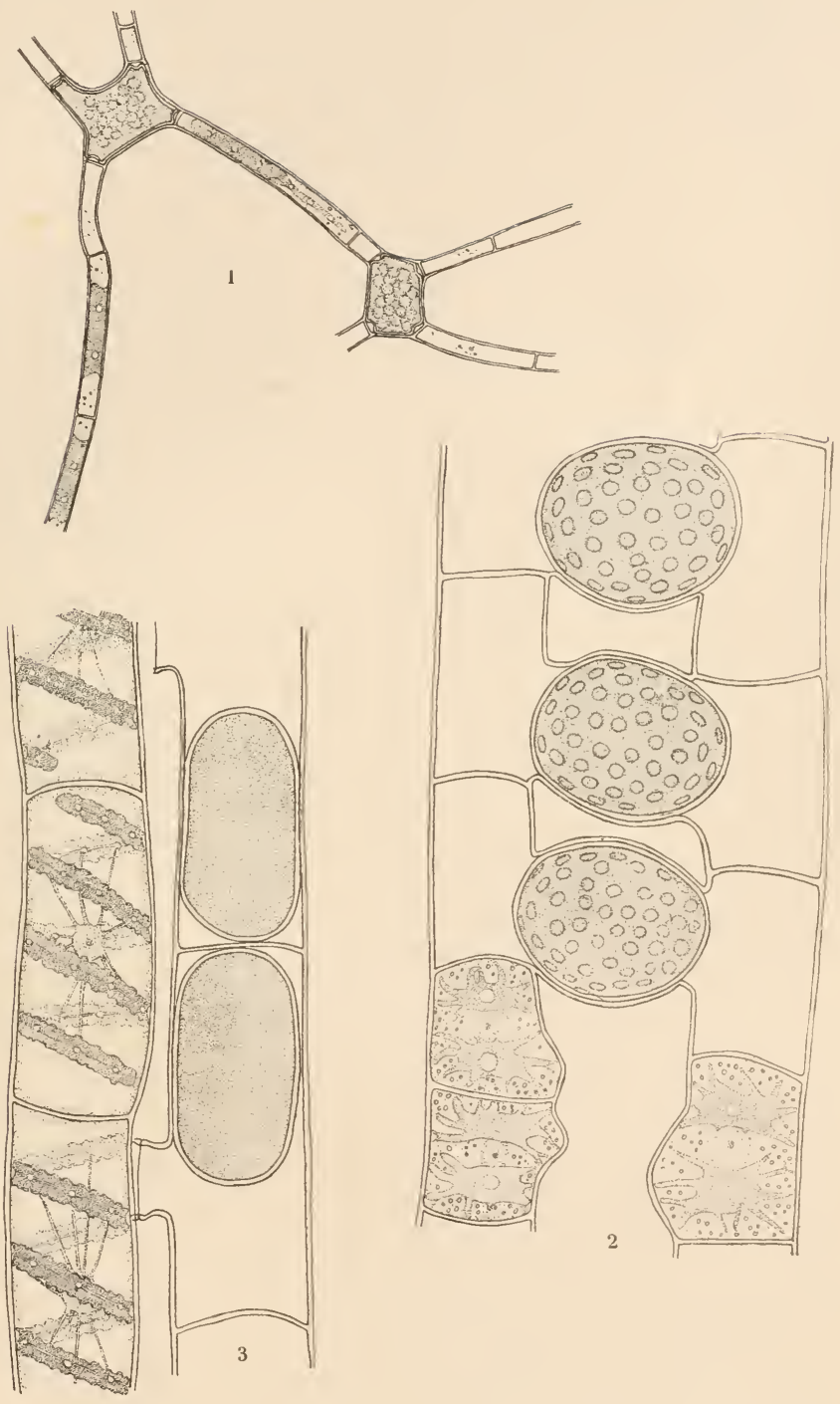



Acanthococcus reticularis Reinsch... 109 ACANTHOSPHAERA Lemm. ...... 128 A. ZACHARIASI Lemm. pl. 29, f. 6-8.. 128 ACTINASTRUM Lag. ........... 164 A. GRACILLIMUM G. M. Smith pl. 48 , f. $3-5 \ldots \ldots \ldots \ldots \ldots \ldots \ldots \ldots$

A. HANTZSCHI Lag. pl, 43, f. $6-7 \ldots . .164$ v. ELONGATUM G. M. Smith pl. 43 ,

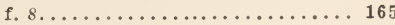
AKONTAE $\ldots \ldots \ldots \ldots \ldots \ldots \ldots \ldots \ldots . \ldots \ldots$ ANABAENA Bory ........... 55 A. AFFINIS Lemm. pl. 8, f. 7..... 57 A. AUGSTUMALIS v. MARCHICA Lemm. pl. 8 , f. $9-10 \ldots \ldots \ldots \ldots \ldots$ A. BORNETIANA Collins pl. 8, f. 3 . . A. CIRCINALIS (Ktz.) Rab. pl. 9, f. $4-5 \ldots \ldots \ldots \ldots \ldots \ldots \ldots \ldots$

v. MACROSPORA (Wittr.) de Toni pl. 9, f. 6 ; pl. 10 , f. $1 \ldots \ldots \ldots \ldots$ A. FLOS-AQUAE (Lyng.) Breb. pl. 10, f. $2-4 \ldots \ldots \ldots \ldots \ldots \ldots \ldots$

A. flos-aquae Klebh. non (Lyng.)

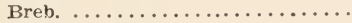

v. TRELEASII Born. \& Flah. pl. 10, f. $5-7 \ldots \ldots \ldots \ldots \ldots \ldots \ldots \ldots$

A. Hassallii (Ktz.) Wittr. ..........

v. macrospora Wittr. ........... A. LEMMERMANNI P. Richt. pl. 10, f. 8 ; pl. 11 , f. $1 \ldots \ldots \ldots \ldots \ldots \ldots$ A. LEVANDERI Lemm. pl. 8, f. 45 . . A. LIMNETICA G. M. Smith pl. 8 , f. 8 A. MACROSPORA v. ROBUSTA Lemm. pl. 8, f. $6 \ldots \ldots \ldots \ldots \ldots \ldots$ A. mendotae Trelease ............ A. PLANCTONICA Brunnth. pl. 8, f. 2 A. SPIROIDES v. CRASSA Lemm. pl. 9, f. 1-s................ Anacystis pulverus Wood ........... ANKISTRODESMUS Corda ........ 134 A. Chodati (Tanner-Fullman) Brunnth. .................. 138 A. FALCATUS (Corda) Ralfs pl. $s 2$, f. 1. . . . . . . . . . . 134 v. ACICULARIS (A. Br.) G. S. West .............. 135 v. MIRABILIS (W \& G. S. West) G. S. West pl. 32, f. $3-5 \ldots \ldots .135$ v. spiralis (Turn.) G. S. West... 135 v. TUMIDUS (W. \& G. S. West) G. S. West pl. 82, f. $2 \ldots \ldots \ldots \ldots 135$
A. lacustre (Chodat) Ostenfeld

A. longissimum v. septatum

(Chodat) Brunnth. ......... 177

A. Pfitzeri (Schrüd.) G. S. West ... 138

A. SPIRALIS (Turn.) Lemm. pl. $\$ 2$, f. $6-7$. ............ 135

APHANIZOMENON Morren ..... 61

A. FLOS-AQUAE (L.) Ralfs pl. 11, f. 2-4. ............ 61

APHANOCHAETACEAE ........ 181

APHANOCHAETE A. Br. ....... 181

A. VERMICULOIDES Wolle pl. 50 , f. $8 . \ldots \ldots \ldots \ldots \ldots \ldots \ldots \ldots 181$

58 APHANOCAPSA Näg. .......... 41

58 A. DELICATISSIMA W. \&. G. S.

West pl. 2, f. 7. .......... 41

59 A. ELACHISTA v. CONFERTA

W. \& G. S. West pl. 2, f. $8 . \ldots \ldots 42$

v. PLANCTONICA G. M.

Smith pl. 3, f. 3. .......... 42

60 A. ENDOPHYTICA G. M. Smith

pl. 2, f. $10 . \ldots \ldots \ldots \ldots \ldots \ldots \ldots . \ldots 42$

A. GREVILLEI (Haas.) Rab.

pl. 3 , f. $1 . \ldots \ldots \ldots \ldots \ldots \ldots \ldots \ldots 43$

60 A. PULCHRA (Ktz.) Rab. pl. 2, f. 9.42

59 A. RIVULARIS (Carm.) Rab.

60 pl. s, f. 2. ............. 43

APHANOTHECE Näg. ......... 43

61 A. CLATHRATA W. \& G. S. West pl. $6, f .3 . \ldots \ldots \ldots \ldots \ldots \ldots \ldots \ldots \ldots 44$

A. NIDULANS P. Richt. pl. 6, f. 1... 44

v. ENDOPHYTICA W. \& G. S.

West pl, 5 , f. $6 . \ldots \ldots \ldots \ldots \ldots 44$

A. PRASINA A. Br. pl. 5, f. $5 . \ldots \ldots 45$

A. STAGNINA (Spreng.) A. Br.

pl. 6 , f. 2. .............. 45

ASTEROCOCCUS Scherffel ........ 103

A. LIMNETICUS G. M. Smith

pl. 20 , f. $7-10 . \ldots \ldots \ldots \ldots \ldots \ldots 104$

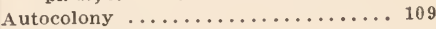

AUTOSPORACEAE ........... 109

Autospore ................... 109

BOTRYOCOCCACEAE ......... 83

BOTRYOCOCCUS $\mathrm{Ktz} . \ldots \ldots \ldots \ldots . . \ldots 3$

B. BRAUNII Ktz. pl. 15, f. 5 . ..... 84

B. Braunii G. S. West non Ktz. .... 83

B. PROTUBERANS v. MINOR

G. M. Smith pl. 15 , f. $6-7 . \ldots \ldots .85$

B. SUDETICUS Lemm. pl. 15, f. $8 \ldots .83$

CARTERIA Diesing ........... 92 
C. CORDIFORMIS (Carter) Diesing pl. 16, f. $1 \ldots \ldots \ldots \ldots \ldots \ldots \ldots \ldots$

C. KLEBSII (Dang.) Dill pl. 16, f. $2-4 . \ldots \ldots \ldots \ldots \ldots \ldots$ CARTERIACEAE $\ldots \ldots \ldots \ldots \ldots \ldots$ CHAETOPHORACEAE .......... 180

CHARACIUM A. Br. ............ 175

C. CURVATUM G. M. Smith

pl. 49, f. $8-15 . \ldots \ldots \ldots \ldots \ldots \ldots 176$

C. CYLINDRICUM Lamb.

pl. 49 , f. $16-19 . \ldots \ldots \ldots \ldots \ldots 177$

C. GRACILIPES Lamb. pl. 49, f. 20-24 178

C. LIMNETICUM Lemm.

pl. 49 , f. $25-29 . \ldots \ldots \ldots \ldots \ldots .177$

C. STIPITATUM (Bachman) Wille pl. 49, 1. 4-7.............. 176

CHLAMYDOMONADACEAE ..... 90

CHLAMYDOMONAS Ehr. ........ 90

C. communis Snow .............. 91

C. DINOBRYONI G. M. Smith pl. 16, f. $5-7 . \ldots \ldots \ldots \ldots \ldots \ldots$

C. EPIPHYTICA G. M. Smith pl. 16 , f. $11-18 . \ldots \ldots \ldots \ldots \ldots \ldots$

C. GLOBOSA Snow pl. 16, f. $8 \ldots \ldots \ldots$ C. SNOWII Printz pl. 16, f. $9-10$. ...

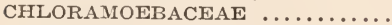
CHLORELLA Beyerinck .......... 108 C. VULGARIS Beyerinck pl. 22, f. 1... 108 CHLOROBOTRYDACEAE ........ 82 CHLOROBOTRYS Bohlin ........ 82

C. LIMNETICUS G. M. Smith pl. 15, f. 9. .............. 82

C. REGULARIS (W. West) Bohlin pl. 15 , f. $10 . \ldots \ldots \ldots \ldots \ldots \ldots \ldots$ CHLOROCHROMONAS Lewis ..... C. MINUTA Lewis pl. 15, f. 1-3..... Chtorococcus regulare $\mathrm{W}$ West ...... CHLOROPHYCEAE .............

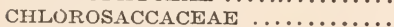
Chodatella ciliata (Lag.) Lemm. .....

v. minor G. M. Smith......... 129

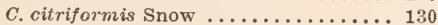

C. Droescheri Lemm. ............ 131

C. longiseta Lemm. ............. 130

C. subsala Lemm. .............. 130

CHROMULINALES ........... 66

CHROOCOCCACEAE $. . . \ldots \ldots \ldots . .$.

CHROOCOCCUS Näg. ...........

C. DISPERSUS (v. Keiss.) Lemm.

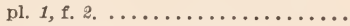

v. MINOR G. M. Smith pl, 1, f. $s$.

C. GIGANTEUS W. West, pl. 2, f. 1...

C. LIMNETICUS Lemm. pl. 1, f. 4. ... v. CARNEUS (Chod.) Lemm. pl. 1, f. $6 . \ldots \ldots \ldots \ldots \ldots \ldots \ldots$

v. DISTANS G. M. Smith

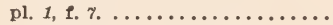
v. ELEGANS G. M. Smith pl. 1 , f. $8 \ldots \ldots \ldots \ldots \ldots \ldots \ldots$ v. SUBSALSUS Lemm. pl. 1, 1. 5 . Chroococcus minor var dispersus

v. Keiss.
C. MINUTUS (Ktz) Näg. Page 2 C. TURGIDUS (Ktz.) Näg. pl. 1, f. 9.31 CHRYSAMOEBA Klebs ......... 67 C. RADIANS Klebs pl. 12, f. 1. .... 67 CHRYSIDASTRUM Lauterborn .... 78 C. CATENTATUM Lauterborn pl. $14, \mathrm{f}, 7-8 . \ldots \ldots \ldots \ldots \ldots \ldots \ldots 78$ CHRYSOMONADINEAE ......... 65 CHRYSOSPHAERELLA Lauterborn 69 C. LONGISPINA Lauterborn pl. 12, f. $7-8 . \ldots \ldots \ldots \ldots \ldots \ldots \ldots 69$

CLADOPHORA Ktz. ............ 182

C. GLOMERATA (L.) Ktz. pl. 50 , f. $1-$ s. .............. 182

CLADOPHORACEAE $\ldots \ldots \ldots \ldots \ldots . . \ldots 182$

Clathrocystis aeruginosa (Ktz.) Henfrey ............... 39

CLOSTERIOPSIS Lemm. .......... 136 C. LONGISSIMA v. TROPICA W. \& G. S. West pl 32, f. $8 . \ldots \ldots \ldots 136$ 1 COCCOGONEALES $\ldots \ldots \ldots \ldots \ldots . .26$ COCCOMYXA Schmidle ........... 139 COELASTREAE ................ 160 COElastrum Näg. ............. 160 C. CAMBRICUM Arch. pl. 42, f. 2-3, 161 C. compositum G. S. West ........ 162 C. MICROPORUM Näg. pl. $\not 1, \mathrm{f}$. $12-13$; pl. 42, f. $1 . \ldots \ldots \ldots \ldots \ldots 160$

C. PROBOSCIDEUM Bohlin pl, $42, \mathrm{f}$. $7-8$; pl. 43, f. $1-2 . \ldots \ldots \ldots \ldots \ldots 162$

C. RETICULATUM (Dang.) Senn pl. 42, e. $4-6$. ............. 161 COELOSPHAERIUM Näg. ........ 33

82 C. DUBIUM Grunow pl. 3 , f. $7 . \ldots . .35$

80 C. KUETZINGIANUM Näg, pl. 3 , f. $4-5$. . . . . . . . . 34

C. NAEGELIANUM Unger pl. $s$, f. 6 ; pl. 4, f. 1 . ........ 35

Coenocyte .................... 88

Cohniella staurogeniaeforme Schröder 149 Collection methods .............. 10 Conferva echinulata J. E. Smith.... 63 CONJUGALES ................ 183 CRUCIGENIA Morren ............... 144 C. APICULATA (Lemm.) Schmidle pl. $s 7$, 1. 1. ............... 146 C. CRUCIFERA (Wolle) Collins pl. 86 , f. $6 . \ldots \ldots \ldots \ldots \ldots \ldots \ldots . \ldots \ldots$ C. FENESTRATA Schmidle pl. $3 \%$, f. 3.148 28 C. IRREGULARIS Wille pl. 36, f. $4-5.145$ 28 C. LAUTERBORNEI Schmidle $30 \quad$ pl. 57, f. $4 . \ldots \ldots \ldots \ldots \ldots \ldots \ldots 148$ 29 C. QUADRATA Morren pl. 36 , f. 10-14. 147 v. punctata (Schmidle) ....... 147

30 C. RECTANGULARIS (Näg.) Gay pl. 36 , f. s. ................ 144

30 C. TETRAPEDIA (Kirchner) W \& G. S. West pl. 57, . 2. ......... 147

30 C. triangularis (Chodat) Schmidle.... 147 29 C. TRUNCATA G. M| Smith pl. 36, f. $7-9 . \ldots \ldots \ldots \ldots \ldots \ldots 146$

28 CRUCIGENIEAE . . . . . . . . 143 
DACTYLOCOCCOPSIS Hansg. ..... 47

D. ACICULARIS Lemm. pl. 6 , f. $8-1048$

D. RHAPHIDIOIDES Hansg.

pl. 6 , f. 7. .............. 47

DICTYOSPHAERIACEAE ....... 104

DICTYOSPHAERIUM Näg. ........ 104

D. EHRENBERGIANUM Näg. pl. 20 , f. $11-12 . \ldots \ldots \ldots \ldots \ldots \ldots .105$

D. PULCHELLUM Wood pl. 20,

f. $13 ;$ pl. 21 , f. $1 \ldots \ldots \ldots \ldots \ldots \ldots 105$

DIMORPHOCOCCUS A. Br. ...... 106

D. LUNATUS A. Br. pl. 21, f. 5. ..... 106

DINOBRYON Ehr. ............ 72

D. BAVARICUM Imhof pl. 18, f. 10. . . 73

D. CALICIFORME Eachm.

pl. 13, f. $5-6 \ldots \ldots \ldots \ldots \ldots \ldots \ldots 73$

D. DIVERGENS Imhof pl. 14, f. 2...

D. SETULARIA Ehr. pl. 18, f. 13;

pl. 14 , f. $1 . \ldots \ldots \ldots \ldots \ldots \ldots \ldots$

D. SOCIALE Ehr. pl. 13, f. 12. ......

D. STIPITATUM Stein pl. 13, f. 11...

D. TABELLARIAE (Lemm.) Pascher pl. 13 , f. $7-9$. . . . . . . . . .

D. utriculus var. tabellariae Lemm. . .

DINOBRYONACEAE ............

ECHINOSPHAERELLA G. M. Smith 128

E. LIMNETICA G. M. Smith

pl. 29 , f. $9-11$. ............ 128

ECHINOSPHAERIDIUM Lemm. .... 128

ELAKTOTHRIX Wille ......... 139

E. GELATINOSA Wille pl. 34, f. 1-3 139

A.VIRDIS (Snow) Printz pl. 3s, f. \%. 140

EUASTROPSIS Lag. ............ 174

E. RICHTERI (Schmidle) Lag.

pl. 49 , f. $3 . \ldots \ldots \ldots \ldots \ldots \ldots \ldots \ldots 175$

Euastrum tetraödon Corda ......... 174

EUCHROMULINACEAE .........

EUCHRYSOMONADINAE .......

EUDORINA Ehr. ............

E. ELEGANS Ehr. pl. 19, $f$. 1, ......

EUHYMENOMONADACEAE ......

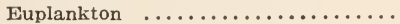

Facultative plankton .............

FRANCEIA Lemm. ............ 131

F. OVALIS (Francé) Lemm. pl. \$1, f. 4131

Fusola virdis Snow ............ 140

Gas vacuoles ................ 33

Geography of Wisconsin ......... 5

Geology of Wisconsin .......... 5

GLOEOCOCCUS ............... 102

GLOEOCYSTIS Näg. ............ 100

G. GIGAS (Ktz.) Lag. pl. 19, f. 2.... 101

GLOEOCYSTOPSIS G. M. Smith .... 102

G. LIMNETICUS G. M. Smith

pl. 20, f. $1-2 . \ldots \ldots \ldots \ldots \ldots \ldots . \ldots 103$

GLOEOTHECE Näg. ........... 45

G. LINEARIS Näg. pl. 6, f. 5. ......

v. COMPOSITA G. M. Smith

pl. 6 , f. $6 \ldots \ldots \ldots \ldots \ldots \ldots \ldots \ldots 46$

GLOEOTAENIUM Hansg. ........ 115

G. LOITLESBERGERIANUM Hansg.

pl. 23, f. $8-9 . \ldots \ldots \ldots \ldots \ldots \ldots .115$
GLOEOTRICHIA J. G. Ag. ....... 63

G. ECHINULATA (J. E. Smith) P.

Richt. pl. 11, f. 5-6. ........ 63

G. pisum Born. et Flah. non Thur. ... 63

GOLENKINIA Chodat ......... 127

G. PAUCISPINA W. \& G. S. West

pl. 29 , f. $4-5$. ............. 127

G. RADIATA Chodat pl, 29, f. 2-3. . 127

GOMPHOSPHAERIA Ktz. ....... 36

G. APONINA Ktz. pl. 4, f. $2-s \ldots . . .37$

v. CORDIFORMIS Wolle pl. 4, f. 437

G. LACUSTRIS Chodat pl. 4, f. 5. ... 36

G. Naegeliana (Unger) Lemm. ..... 35

GONIUM Mueller .............. 94

G. PECTORALE Mueller

pl. 16 , f. $14-15$. ............ 94

Heleoplankton ............... 5

Herposteiron hyalothecae Hansg. .... 181

4 HETEROCHLORIDALES ....... 79

4 HETEROCOCCALES .......... 80

Hormogones ................. 26

HETEROKONTAE .......... 79

HETEROTRICHALES ........ 86

FiORMOGONEALES ........... 49

Hormogones ................ 48

HYALOBRYON Lauterborn ....... 75

IT. Lauterbornei var mucicola Lemm. 75

H. MUCICOLA (Lemm.) Pascher

pl. 14, f. $3-4 . \ldots \ldots \ldots \ldots \ldots \ldots \ldots 75$

HYDRODICTYACEAE .......... 165

HYDRODICTYON Roth ......... 165

H. RETICULATUM (L.) Lag.

pl. 44 , f. 6 ; pl. 45 , f. $1 . \ldots \ldots \ldots \ldots 166$

HYDRURINEAE ............. 76

Ineffigiata neglecta W. \& G. S. West 84

ISOCHRYSIDALES $\ldots \ldots \ldots \ldots \ldots 69$

ISOKONTAE ............. 88

Key to the genera ............ 21

KIRCHNERIELLA Schmidle ...... 140

K. aperta Teiling ............. 143

K. CONTORTA (Schmidle) Bohlín pl. 85 , f. $7 . \ldots \ldots \ldots \ldots \ldots \ldots \ldots 143$

K. ELONGATA G. M. Smith pl. 36 , f. $1-2 . \ldots \ldots \ldots \ldots \ldots \ldots 143$

K. LUNARIS (Kirchner) Möbius

pl. 84, f. 4. ............. 141

v. DIANAE Bohlin pl. 34, f. 5. .. 141

v. IRREGULARIS G. M. Smith

pl. 35 , f. 1. . . . . . . . . 142

K. OBESA (W. West) Schmidle

pl. 35 , f. $2-3$. ............ 142

v. APERTA (Teiling) Brunnthaler pl. 35 , f. $5-6$. . . . . . . . 143

v. contorta Schmidle ......... 143

v. MAJOR (Bernard) G. M.

Smith pl. 35 , f. 4. . . . . . . . 142

LAGERHEIMIA Chođat _....... 129

L. CILIATA (Lag.) Chodat

pl. 31 , f. $1-2 . \ldots \ldots \ldots \ldots \ldots \ldots 129$

v. MINOR G. M. Smith pl. 31, f. \$. 129

L. CITRIFORMIS (Snow) G. M.

Smith pl. 30, f. 1 - . ......... 130 
L. DROESCHERI (Lemm.) Printz pl. 30 , f. $5-\gamma$. . . . . . . . . .

L. LONGISETA (Lemm.) Printz pl. 30 , f. $8-9 . \ldots \ldots \ldots \ldots \ldots \ldots .130$ v. MAJOR G. M. Smith

pl. 30 , f. $10-12 \ldots \ldots \ldots \ldots \ldots . \ldots 130$

L. SUBSALSA Lemm. pl. 30 , f. 3-4. . . 130

Lake areas of Wisconsin ......... Lakes

Altitude .................

Chemical composition of water.. Formation of Wisconsin Lakes ..

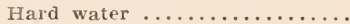

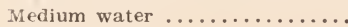
Origin of Names ............

Size $\ldots \ldots \ldots \ldots \ldots \ldots \ldots \ldots \ldots$

Soft water $\ldots \ldots \ldots \ldots \ldots \ldots \ldots$

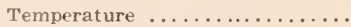

Lemmermannia emarginata

(Schröder) Chodat ........... 147

Lemmermannia tetrapedia (Kirch-

ner) Lemm. ................ 148

List of Lakes studied ......... 13-19

LYNGBYA C. A. Ag. ........... 52

L. BIRGEI G. M. Smith pl. 7, f. 1/-1.5.

L. CONTORTA Lemm. pl. 7 , f. $12-13$.

L. LIMNETICA Lemm. pl. 7, f. 9-11.

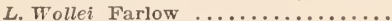

L. Wollei Treleast non Farlow ...... MALLOMONADACEAE .........

MALLOMONAs Perty ............

M. ALPINA Pascher \& Ruttner

pl. 12 , f. $\% \ldots \ldots \ldots \ldots \ldots \ldots \ldots$

M. CAUDATA Iwanoff pl. 12, f. $6 . \ldots$

M. PRODUCTA (Zach.) Iwanoff

pl. 12, f. $2 . \ldots \ldots \ldots \ldots \ldots \ldots \ldots \ldots$

v. MARCHICA Lemm. pl. 12, f. 3 . M. TONSURATA Teiling pl. 12, f. 5. . . MERISMOPEDIA Meyen ......... M. ELEGANS A. Br. pl. 2, f. 5. .....

v. MAJOR G. M. Smith pl. 2, f. 6 . M. GLALCA (Ehr.) Näg. pl. 2, f. 4.... M. PUNCTATA Meyen pl. 2, f. 3. ... M. TENUISSIMA Lemm. pl. 2, f. 2. . . MICRACTINIEAE ........... 125 MICRACTINIUM Fresenius ....... 125 M. PUSILLUM Fresenius

pl. 28 , f. $1-3 . \ldots \ldots \ldots \ldots \ldots \ldots \ldots 125$

v. ELEGANS G. M. Smith

pl. 29 , f. $1 . \ldots \ldots \ldots \ldots \ldots \ldots \ldots 126$

M. QUADRISETUM (Lemm.) G. M.

Smith pl. 28, f. 4. .......... 126

MICROCYSTIS Ktz. .......... 38

M. AERUGINOSA Ktz. pl. 5, f. 2-3. 39

v. MAJOR (Wittr.) G. M. Smith pl. 4, f. 6. ..............

M. FLOS-AQUAE (Wittr.) Kirchner

pl. 5 , f. $1 . \ldots \ldots \ldots \ldots \ldots \ldots \ldots$.

M. ICHTHYOBLABE Ktz. ....... M. INCERTA Lemm. pl. 5, f. 4. . . . . M. PULVERA (Wood) Migula ...... Monactinus duodenarius Bailey...... 16
Page

M. octonarius Bailey ........... 167

MOUGEOTIA C. A. Ag. ........... 184 M. VIRIDIS (Ktz.) Wittr. pl. 51, f. 1. 184 Myxonema lubricum (Dillw.) Fries... 180 MYXOPHYCEAE ........... 26 OCHROMONADACEAE ......... 71 OCHROMONADALES $\ldots \ldots \ldots \ldots$ 70

6 OOCYSTEAE ................. 110

Oocystella Lemm. .............. 114

6 OOCYSTIs Näg. ............... 110

8 O. BORGEI Snow pl. 22, f. 4. ....... 111

5 O. ciliata Lag. . . . . . . . . . . . 129

7 O. CRASSA Wittr. pl. 22, f. $12-13 . . . .113$

7 O. ELLIPTICA WV. West pl. 22, f. 5... 111

O. EREMOSPHAERIA G. M. Smith pl. 23 , f. $1-2 \ldots \ldots \ldots \ldots \ldots \ldots \ldots . \ldots 113$

O. GLOEOCYSTIFORMIS Borge pl. 22,

f. $7 \ldots \ldots \ldots \ldots \ldots \ldots \ldots \ldots \ldots \ldots \ldots \ldots \ldots$

O. LACUSTRIS Chodat pl. 22, f. 8-9. 112

O. NATANS v. MAJOR G. M. Smith pl. 28 , f. $4-5 \ldots \ldots \ldots \ldots \ldots \ldots \ldots 114$

O. PANDURIFORMIS v. MINOR G.

M. Smith pl. 28, f. $8 \ldots \ldots \ldots \ldots \ldots 114$

O. PARVA W. \& G. S. West pl. 22, f. 6112

O. PUSILLA Hansg. pl. 22 , f. $3 \ldots \ldots .111$

O. SOLITARIA Wittr. pl. 22, f. $11 \ldots 113$

O. SUBMARINA Lag. pl. 22, f. 10... 113

OPHIOCYTIACEAE .......... 85

OPHIOCYTIUM Näg. . . . . . . 85

O. CAPTTATUM Wolle pl. 15, f. 12-13. 86

v. LONGISPINUM (Möbius) Lemm. pl. 15, f. 1$\}-16 \ldots \ldots \ldots \ldots \ldots \ldots . .66$

O. PARVULUM (Perty) A. Br. pl. 15, f. $11 \ldots \ldots \ldots \ldots \ldots \ldots \ldots \ldots$

OSCILLATORIA Vaucher ....... 50

O. PROLIFICA (Grev.) Gom. pl. 7 , f. $s-5 \ldots \ldots \ldots \ldots \ldots \ldots \ldots \ldots \ldots 1$

O. RUBESCENS D. C. ......... 51

O. TENUIS C. A. Ag. pl. 7 , f. $6 \ldots \ldots 52$

v. TERGESTINA (Ktz.) Rab. pl. 7 ,

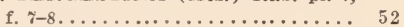

OSCILLATORIACEAE ........ 49

PALMELLACEAE .......... 100

PANDORINA Bory .......... 95

P. MORUM Bory pl. 16, f. 16-17.... 95

PEDIASTRUM Meyen ........... 166

P. ARANEOSUM Racib. pl. 45, f. 11. . 168

v. RUGULOSUM (G. S. West) G. M.

Smith pl. 45 , f. $12-13 \ldots \ldots \ldots \ldots .168$

P. BIRADIATUM Meyen pl. 48, f. 5-8 173

P. BORYANUM (Turp.) Menegh. pl. 46, f. $2-7 \ldots \ldots \ldots \ldots \ldots \ldots \ldots \ldots . \ldots \ldots$

v. LONGICORNE Racib. pl. 46, f. 9. 170

v. longicorne forma glabrum Racib. 170

v. longicorne forma granulatum

Racib. .................. 170

v. UNDULATUM Wille pl. 46 , f. 8 . 170

P. DUPLEX Meyen pl. 46 , f. 14-16... 171

v. CLATHRATUM (A. Br.) Lag.

pl. 47, f. $1-3 \ldots \ldots \ldots \ldots \ldots \ldots \ldots 171$

v. COHAERENS Bohlin pl, $\$ 8, t$. \&- $\$ 17$ s 
Page Page

v. GRACILLIMUMI W. \& G. S. West pl. 47 , f. $8-11$; pl. 48 , f. $1-2 \ldots \ldots 172$ v. RETICULATUM Lag. pl. $4 \%$, f. $4-7172$ v. reticulatum forma cohaerens (Bohl.) Brunnth. .......... 173 v. ROTUNDATUM Lucks pl. 46, f. 17172 P. INTEGRUM Nag. pl. 45, f. 7..... 168 v. PRIVA Printz pl. 45, f. 8-10.... 168 P. rotula (Ehr.) A. Br. ......... 173 P. SCULPTATUM G. M. Smith pl. 46 ,

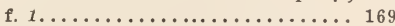

P. SIMPLEX v. DUODENARIUM

(Balley) Rab. pl. 45, f. 2-6..... 167 v. clathratum (Schröter) G. S. West 167 P. TETRAS (Ehr.) Ralfs pl. 48, f. 9-12 17 3 v. OBTUSATA Racib. .......... 174 v. TETRAODON (Corda) Hansg. pl. 48 , f. $13-14$; pl. 49 , f. $1-2 \ldots \ldots \ldots 174$ PERONIELLA Gobi ........... 81 P. PLANCTONICA G. M. Smith pl. 15 , f. $4 \ldots \ldots \ldots \ldots \ldots \ldots \ldots \ldots \ldots$ PHAEOCAPSACEAE $\ldots \ldots \ldots \ldots \ldots$ PHAEOCAPSALES $\ldots \ldots \ldots \ldots \ldots$ PHAEOCOCCUS Borzi ........... P. PLANCTONICUS W. \& G. S. West $\mathrm{pl}, 14, \mathrm{f} .5 \ldots \ldots \ldots \ldots \ldots \ldots \ldots 76$ PHAEOPHYCEAE $\ldots \ldots \ldots \ldots \ldots .65$

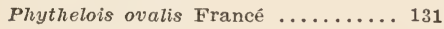
Phytoplankton .............. 1 Pithiscus Klebsii Dangeard....... 93 PLANKTOSPHAERIA G. M. Smith. . 103 P, GELATINOSA G. M. Smith pl. 20,

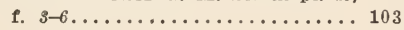

PLANOSPORACEAE .......... 175 PLECTONEMA WOLLEI Farlow.... 54 PLEODORINA Shaw .......... 96 P. CALIFORNICA Shaw pl. 17, f. 1-3 97 Polycystis ichthyoblabe Ktz....... 38 POLYEDRIOPSIS Schmidle ....... 124 P. SPINULOSA Schmidle pl. 27 , f. $7-8124$ Polyedrium gracile Reinsch........ 122 $P$. hastatum var. palatinum Schmidle 121 P. lobulatum Näg.............. 122

P. muticum v. punctulatum Reinsch.. 116

P. tetraedricum Näg........... 118

v. hastatum Reinsch. .......... 121

P. trigonum Näg. ............ 117

v. gracile Reinsch............ 117

v. setigerum (Arch.) Schröder..... 117

PROTOCOCCACEAE .......... 108

FROTOCOCCALES ........... 99

Protococcus minutus Ktz. ......... 28

Pseudocilia ................ 102

Pseudovacuoles $\ldots \ldots \ldots \ldots \ldots \ldots \ldots \ldots . \quad 33$

Pyrenoids ................. 88

QUADRIGULA Printz .......... 137

Q. CHODATI (Tanner-Fullman) G. M. Smith pl. $\$ 8$, f. 3........ 138

Q. LACUSTRIS (Chodat) G. M. Smith pl. 33, f. $4-6 \ldots \ldots \ldots \ldots 139$

Q. PFITZERI (Schröder) G. M. Smith pl. ss, f. $1-2 \ldots \ldots \ldots \ldots \ldots 138$
Relative abundance of different species 28

RHABDODERMA Schmidle \& Lauterborn ................ 46

R. LINEARE Schmidle \& Lauterborn pl. 6 , f. $4 \ldots \ldots \ldots \ldots \ldots \ldots \ldots \ldots 47$

Rhaphidium Braunii var. lacustre Chodat ..................... 139

R. Chodati Tanner-Fullman............. 138

R. longissimum var. septatum Chodat 177

v. tropicum W. \& G. S. West...... 136

R. Pfitzeri Schröder............ 138

R. spirale Turner................. 135

RHIZOCHRYSIDINAE .......... 77

RHIZOCHRYSIS Pascher ......... 77

R. LIMNETICA G. M. Smith pl. 14, f. 677

R. PLANCTONICA Pascher........ 78

Richteriella botryoides (Schmidle)

Lemm. ................. 125

forma fenestrata Chodat........ 125

forma tetraedrica Lemm. ......... 126

Rivularia echinulata J. E. Smith.... 68

RIVULARIACEAE $\ldots \ldots \ldots \ldots \ldots \ldots 62$

SCENEDESMUS Meyen ............... 150

S. ABUNDANS (Kirchner) Chodat pl. 89 , f. $2 s-25 \ldots \ldots \ldots \ldots \ldots \ldots \ldots . \ldots \ldots$

v. ASYMMETRICA (Schröder) G.

M. Smith pl. 40 , f. $6-8 \ldots \ldots \ldots \ldots 157$

v. BREVICAUDA G. M. Smith pl. 40, f. $s-5 \ldots \ldots \ldots \ldots \ldots \ldots \ldots \ldots . \ldots \ldots$

v. LONGICAUDA G. M. Smith pl. 89, f. $26-87 \ldots \ldots \ldots \ldots \ldots \ldots \ldots \ldots . \ldots \ldots$

S. ACUMINATUS (Lag.) Chodat pl. 38 , f. $1-4 \ldots \ldots \ldots \ldots \ldots \ldots \ldots \ldots .152$

S. ACUTIFORMIS Schröder pl. 89 , $f$.

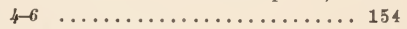

S. alternans Reinsch............ 158

S. ARCUATUS Lemm. pl. 38 , f. 12-14.. 153

v. CAPitatus G. M. Smith pl. 38 ,

f. $15-16 \ldots \ldots \ldots \ldots \ldots \ldots \ldots \ldots \ldots$

v. PLATYDISCA G. M. Smith pl. $s 9$,

ค. $1-$ s................. 154

S. ARMATUS (Chodat) G. M. Smith pl. 39 , f. $\gamma-10 \ldots \ldots \ldots \ldots \ldots \ldots \ldots 154$ v.MAJOR G. M. Smith pl. 39 , f. 11. . 155 S. BERNARDII G. M. Smith pl. $s 8, \mathrm{f}$. $5-9 \ldots \ldots \ldots \ldots \ldots \ldots \ldots \ldots \ldots \ldots \ldots \ldots \ldots \ldots \ldots$

S. BIJUGA (Turpin) Lag. pl. $37, \mathrm{f}$. 18-20 .................. 152

v. ALTERNANS (Reinsch) Borge pl. 88 , f. $10-11 \ldots \ldots \ldots \ldots \ldots \ldots \ldots 153$

S. bijugatus (Turpin) Ktz. ........ 152

S. BRASILIENSIS Bohlin pl. 39 , f.

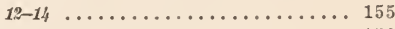

S. caudatus Näg. non Corda........ 156

S. DENTICULATUS Lag. pl. 39, f. $17-19 \ldots \ldots \ldots \ldots \ldots \ldots \ldots \ldots \ldots \ldots \ldots \ldots \ldots$

S. DIMORPHUS (Turpin) Ktz. pl. 37 ,

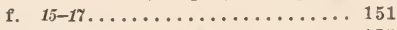

S. HYSTRIX Lag. pl. 39, f. 15-16. . . 155

S. LONGUS Meyen pl. \$9, f. 20-22... 156 v. NAEGELII (Breb.) G. M. Smith pl. 40 , f. $1-9 \ldots \ldots \ldots \ldots \ldots \ldots . \ldots \ldots$ 
S. Naegelii Breb. ............. Page

S. OBLIQUUS (Turpin) Ktz, pl. $\$ \%$, f. $12-14 \ldots \ldots \ldots \ldots \ldots \ldots \ldots 151$

S. OPOLIENSIS P. Richter pl. 41, $\mathbf{f}$ $8-11 \ldots \ldots \ldots \ldots \ldots \ldots \ldots \ldots . \ldots \ldots$. 159 S. QUADRICAUDA (Turpin) Breb. pl. 40 , f. $9-11 \ldots \ldots \ldots \ldots \ldots \ldots \ldots$ v. abundans (Kirchner) Lag...... 157 v. asẏmmetrica Schröder ....... 157 v. LONGISPINA (Chodat) G. M. Smith pl. 40, f. 12-14......... 159

v. MAXIMUS W. \& G. S. West pl. $41, \mathrm{f} .1-2 \ldots \ldots \ldots \ldots \ldots \ldots \ldots \ldots . \ldots 159$

v. PARVUS G. M. Smith pl. 40 , f. 17158 v. QUADRISPINA (Chodat) G. M. Smith pl. 40. 1. $15-16 \ldots \ldots \ldots \ldots .158$

v. setosus (Kirchner) Lag. ....... 156 v. WESTII G. M. Smith pl. 41, 1 . $s-7 \ldots \ldots \ldots \ldots \ldots \ldots \ldots \ldots \ldots$ SCHROEDERIA Lemm. ........... 136 S. JUDAYI G. M. Smith pl. 32, f. 9-11 137 S. SETIGERA (Schröder) Lemm. pl.

32, f. $12 \ldots \ldots \ldots \ldots \ldots \ldots \ldots \ldots \ldots 137$ SELENASTREAE ............. 132 SELENASTRUM Reinsch ........ 132 S. acuminatum G. S. West non Lag. 133

S. acuminatum Lag. ............ 152

S. BIBRAIANUM Reinsch

pl. $\$ 7$, f. 6 -7. ............ 133

S. GRACILE Reinsch pl. s1, f. 5 . .... 133

S. WESTII G. M. Smith pl. 31, 1. 8-10 133 Selenosphaerium americanum Bohlin. 163 SIPHONOCLADIALES .......... 182 SORASTRUM Ktz. ............. 162 S. AMERICANUM (Bohlin) Schmidle

pl. 4h, f. 1. ................ 163 UNDULATUM G. M. Smith

pl. 44, f. 2-3............ 163 S. SPINULOSUM Näg. pl. 44, f. 4-5. 163 SPHAEROCYSTIS Chodat ........ 101 S. SCHOETERI Chodat pl. 19, f. s-4. 101 SPIROGYRA Link ............. 185 S. PORTICALIS (Mueller) Cleve

pl. 51 , f. 8. . . . . . . . . . 185 SPIRULINA Turpin ........... 49 S. MAJOR Ktz. pl. 7, f. 1. ........ 50 S. PRINCEPS (W. \& G. S. West)

G. S. West pl. 7. f. 2. ....... 50 Staurogenia apiculata Lemm. ...... 146 S. cruciatum Wolle .............. 145 S. crucifera Wolle .............. 145 S. fenestrata Schmidle ............ 148 S. Lauterbornei Schmidle ......... 148 S. multiseta v. punctata Schmidle ... 147 S. tetrapedia Kirchner .......... 147 S. triangularis Chodat ........... 147 STIGEOCLONIUM Ktz. ......... 180 S. LUBRICUM (Dillwyn) Ktz.

pl. 50 , f. 7. ............. 180 SYNURA Ehr. ............... 70 S. UVELLA Ehr. pl. 12, 1. 9-10. .... 70 Tetracoccus botryoides W. West ..... 107
TETRAdESMUS G. M. Smith Page T. WISCONSINENSIS G. M. Smith

pl. 57 , 1. $7-11$. ........... 150

TETRAEDREAE ............. 115

TETRAEDRON Ktz. ........... 115

T. arthrodesmiforme v. lobulatum

Wolosz ................... 122

T. CAUDATUM (Corda) Hansg.

pl. 25 , f. $4-7 . \ldots \ldots \ldots \ldots \ldots \ldots 120$

v. LONGISPINUM Lemm. pl. 25 , f. $8-12 \ldots \ldots \ldots \ldots \ldots \ldots \ldots . \ldots \ldots$

T. CONSTRICTUM G. M. Smith

pl. 25, f. 22-24. . . . . . . . . . 122

T. ENORME (Ralfs) Hansg. pl. 27, f. 6. 124

T. GRACILE (Reinsch) Hansg. pl. $25, \mathrm{f}, 1-5 . \ldots \ldots \ldots \ldots \ldots \ldots . .122$

T. HASTATUM (Reinsch) Hansg.

pl. 25 , f. 18. ................ 121

v. PALATINUM (Schmidle)

Lemm. pl. 25, f. $19-21$. . . . . . 121

T. LIMNETICUM Borge pl 27, f. 1-3. 123

T. LOBULATUM (Näg.) Hansg.

pl. 26, f. $6-7 . \ldots \ldots \ldots \ldots \ldots \ldots 122$

v. POLYFURCATUM G. M.

Smith pl. 26, f. 8. ......... 123

T. MINIMUM (A. Br.) Hansg.

pl. 24, f. $10-13 . \ldots \ldots \ldots \ldots \ldots \ldots . \ldots 118$

T. MUTICUM v. PUNCTULATUM

(Reinsch) de Toni pl. 23, f. 10-13. 116

T. PENTAERDICUM W. \& G. S.

West pl. 25, f. 13-17. ......... 120

v. minimum W. \& G. S. West ... 121

T. PLANCTONICUM G. M. Smith

pl. 27 , f. $4-5 . \ldots \ldots \ldots \ldots \ldots \ldots 123$

T. proteiforme G. M. Smith non (Turn.)

Brunnthaler .............. 117

T. REGULARE Ktz. pl. 24, f. 14. .... 118

T. regulare Chodat non Ktz. ....... 119

v. INCUS Teiling pl. 24, f. 15-16. 118

v. TORSUM (Turner) Brunn-

thaler pl. 24, f. $17-18 . \ldots \ldots \ldots 119$

T. spinulosum Schmidle ......... 124

T. TRIGONUM (Näg.) Hansg.

pl. 28, f. $1,-16 \ldots \ldots \ldots \ldots \ldots \ldots 117$

v. GRACILE (Reinsch) de Toni

pl. 24, f. $5-9 . \ldots \ldots \ldots \ldots \ldots \ldots 117$

v. SETIGERUM (Archer) Lemm.

pl. 24 , f. 1 -4. . . . . . . . 117

T. VERRUCOSUM G. M. Smith

pl. 25, f. 2-3. .............. 119

T. VICTORIEAE Wolos. ......... 119

v. MAJOR G. M. Smith pl. 24,

f. $19-22$; pl. 25 , f. 1 . . . . . 119

Tetrapedia emarginata Schröder .... 147

T. pentä̈dricum Chodat ........... 120

T. setigera Archer ......................... 117

TETRASPORA Link ........... 102

T. LACUSTRIS Lemm. pl. 19, f. 5-6. 102

TETRASTRUM Chodat ......... 149

T. apiculatum (Lemm.) Brunnthaler. . 146

T. multisetum (Schmidle) Chodat ...147 


\section{T. STAUROGENIAEFORME}

(Schröder) Lemm. pl. 57, f. 5-6. 149 TRICHODESMIUM Ehr. ........ 54

T. LACUSTRE Klebahn pl. 8, 1. 1... TRIBONEMA Derbes et Solier ...... T. BOMBYCINA v. DEPAUPERATA Wille.$\ldots \ldots \ldots \ldots \ldots \ldots \ldots$. T. MINUS (Wille) Hazen pl. 15 , f. $17-18 . \ldots \ldots \ldots \ldots \ldots \ldots 87$ TRIBONEMACEAE $\ldots \ldots \ldots \ldots \ldots \ldots .87$

Trichomes ................. 48

TROCHISCIA Ktz. ............ 108 T. RETICULARIS (Reinsch) Hansg. pl. 22 , f. 2. ............. 109

Tychoplankton ...............

ULOTRICHACEAE ........... 178

ULTRICHALES ................ 178

ULOTHRIX Ktz. ............. 179

U. SUBCONSTRICTA G. S. West pl. 50 , f. $4-5 . \ldots \ldots \ldots \ldots \ldots \ldots . \ldots 179$

U. ZONATA (Weber \& Mohr) Ktz. pl. 50, f. 6 .

179
Uroglena americana Calkins ....... 71

UROGLENOPSIS Lemm. ......... 71

U. AMERICANA (Calkins) Lemm. pl. 18, f. 1 -4. ............ 71

VOLVOCACEAE ............. 93

VOLVOCALES ............... 89

VOLVOX L. .................. 97

V. AUREUS Ehr. pl. 18, 1. 2. ...... 98

V. GLOBATOR L. pl. 18 , f. $3-5 \ldots \ldots .98$

V. MONONAE G. M. Smith, pl. 18, f. 199

WESTELLA de Wildeman ........ 106

W. BOTRYOIDES (W. West) de

Wildeman pl. 21, f. 4......... 107

v. MAJOR G. M. Smith ....... 107

W. LINEARIS G. M. Smith

pl. 21 , f. 2 -s. ............. 107

Zooplankton ..................... 1

ZYGNEMA C. A. Ag . .......... 184

Z. PECTINATUM (Vaucher) C. A.

Ag. pl. 51, f. 2. . . . . . . . 185 




